\title{
Barragán em três tempos
}

Marina Panzoldo Canhadas

Dissertação apresentada ao Programa de Pós-Graduação da Faculdade de Arquitetura e Urbanismo da Universidade de São Paulo para obtenção do título de Mestre em Arquitetura e Urbanismo

Área de concentração

Projeto de Arquitetura: teorias e métodos

Orientadora

Profa. Dra. Marta Vieira Bogéa

São Paulo 
Autorizo a reprodução e divulgação total

ou parcial deste trabalho, por qualquer

meio convencional ou eletrônico, para

fins de estudo e pesquisa, desde que

citada a fonte.

E-mail:

marina_canhadas@usp.br

info@marinacanhadas.com.br

Canhadas, Marina

Barragán em três tempos / Marina Canhadas;

orientadora Marta Bogéa. - São Paulo, 2018.

$192 \mathrm{p}$.

Dissertação (Mestrado) - Faculdade de Arquitetura e Urbanismo da Universidade de São Paulo. Área de concentração: Projeto da Arquitetura

1. Luis Barragán. 2. Arquitetura Moderna. 3. Paisagem. 4. Imaginário. I. Bogéa, Marta, orient. II. Título.

EXEMPLAR REVISADO E ALTERADO EM RELAÇÃO À VERSÃO ORIGINAL, SOB RESPONSABILIDADE DA AUTORA E ANUÊNCIA DA ORIENTADORA.

Versão original, em formato digital, ficará arquivada na Biblioteca da Faculdade.

São Paulo, 17 de maio de 2018. 
Barragán em três tempos

Marina Panzoldo Canhadas
Dissertação apresentada ao Programa de Pós-Graduação da Faculdade de Arquitetura e Urbanismo da Universidade de São Paulo para obtenção do título de Mestre em Arquitetura e Urbanismo.

Aprovada em:

Banca examinadora

Prof. Dr.

Julgamento:

Prof. Dr.

Julgamento:

Prof. Dr.

Julgamento:
Instituição:

Assinatura:

Instituição:

Assinatura:

Instituição:

Assinatura: 


\section{Agradecimentos}

Meu envolvimento com a obra de Luis Barragán iniciou-se com as aulas de Humberto Ricalde no curso latu-sensu "Geografia, arquitetura e cidade" na Escola da Cidade (2010), a quem devo agradecer primeiramente (in memoriam). Depois disso, morei por dois anos no México onde pude vivenciar de perto a obra do arquiteto mexicano (2011-2013).

Esta pesquisa não teria sido realizada sem o apoio e incentivo de diversos interlocutores ao longo de todo o processo. Agradeço:

a Faculdade de Arquitetura e Urbanismo da Universidade de São Paulo (FAU USP);

a Marta Vieira Bogéa, minha orientadora, pelo profundo interesse, envolvimento e contribuição para a pesquisa. As sugestões, comentários e o olhar sempre atento da Marta foram de extrema importância;

aos professores Luis Antonio Jorge e José Lira, pelos precisos e construtivos comentários na banca de qualificação direcionando a pesquisa para outros possíveis caminhos;

ao professor Artur Simões Rozestraten e colegas da disciplina AUT5836, pelas ricas trocas ao longo da disciplina;

a Fundação Barragán na Cidade do México, por me permitir a consulta no arquivo pessoal de Luis Barragán (à Catalina Corcuera, Adriana Garrido Neri, Chakceel Rah Blancas e Juan Palomar);

a Jesús López, que esteve por perto, mesmo longe, durante toda a pesquisa;

a Daniel Garza Usabiaga, pela prazerosa conversa sobre Luis Barragán;

a Paco Gutierrez, por me indicar caminhos em Guadalajara;

a Luz Elena Castillo Díaz, por me levar nas ruínas da fazenda da família de Barragán;

a Onnis Luque, por gentilmente conceder algumas fotografias presentes na dissertação;

a Luis Beltran, por toda a troca referente ao projeto Casa Estúdio Quatro Pintores; 
aos amigos no México que generosamente me receberam em suas casas durante as minhas duas visitas à Cidade do México ao longo da pesquisa, Antonio Espinoza e Victor Acoltzi;

a Iván Zuñiga Soto e Gabriel Beas;

aos moradores das obras de Luis Barragán que me receberam em suas casas para uma conversa: José Manuel Barcena Ortega, Martin Luque, Antonio Gálvez e Carlos Ochoa Fernández;

a Julio Mariutti, muito obrigada;

a Daniele Pisani, que em uma de suas vindas ao Brasil topou conversar sobre a minha pesquisa;

a Lizete Rubano, Felipe Moreira, Luciano Abbamonte e Marcus Vinícius Damon pelo incentivo no início da formulação do projeto de pesquisa;

a Mario Figueroa;

a Ricardo Luis Silva;

a Flavia Tenan, pela tradução dos contos de Ferdinand Bac;

a Maria Beatriz Alves;

aos orientandos da Marta que viraram amigos Gustavo Kerr, Carmela Rocha e Luís Tavares;

a Oliver De Luccia, pela dedicação na publicação dos projetos das disciplinas AUP156 e AUP160 durante o estágio no programa PAE;

a Coordenação de Aperfeiçoamento de Pessoal de Nível Superior (CAPES), pelo apoio à pesquisa;

aos meus pais, Eneida e José Eduardo;

a Joaquin Gak, obrigada por tudo. 


\section{Sumário}

Resumo / Abstract 08

Prólogo 11

Introdução 20

\section{Primeira fase $1927-1935$}

1.1 Mapas 27

1.2 As paisagens da infância 32

1.3 Contextos histórico e cultural e os anos de formação 39

1.4 Primeiro encontro com a Europa $\mathbf{4 2}$

1.5 Retorno ao México 48

1.6 A Casa González Luna 51

\section{Segunda fase $1936-1944$}

2.1 Viagens à Chicago e Nova lorque e o retorno à Europa 71

2.2 Contextos histórico e cultural no México 78

2.3 Retorno ao México e os edifícios urbanos 82

2.4 Edifício Casa-Estúdio para Quatro Pintores 86

\section{Terceira fase a partir de 1945}

3.1 Contexto histórico nos anos 1940 e 1950 no México 99

3.2 El Pedregal . o desenho do bairro 107

3.3 Construções em Tacubaya . o desenho das casas 114

3.4 Viagem ao norte da África 147

3.5 Capela e Ampliação do Convento de Tlalpan . o lugar do culto 148

Considerações finais 160

Lista de imagens 174

Referências bibliográficas 179

Cronologia de obras de Luis Barragán 186 
Acreditava em infinitas séries de tempos, numa rede crescente e vertiginosa de tempos divergentes, convergentes e paralelos. Essa trama de tempos que se aproximam, se bifurcam, se cortam ou que secularmente se ignoram, abrange todas as possibilidades. (BORGES, 1941, p. 92) 


\section{Resumo}

Este trabalho analisa a produção arquitetônica de Luis Barragán reconhecendo as três fases apresentadas pela historiografia mexicana (Aníbal Figueroa Castrejón, 1989; Enrique X. de Anda, 1992; e Louise Noelle, 1996). Busca olhar sobre o contexto de cada uma dessas fases para refletir sobre obras representativas de cada uma delas. Na primeira fase, estuda a Casa González Luna (1928-1929) em Guadalajara; na segunda fase, o Edifício Casa-Estúdio para 4 pintores (1939-1941) e na terceira, as obras Jardines del Pedregal (1945-1954), as construções em Tacubaya (1941-1948) - Casa Ortega, Casa Estúdio e Ateliê de Luis Barragán e a Capela e Ampliação do Convento de Tlalpan (1953-1960 e 1979-1980), na Cidade do México. A pesquisa propôs a construção do imaginário de Luis Barragán através das paisagens citadas por ele, dos autores que ele reconhece em sua interlocução, das viagens realizadas por ele e do discurso feito pelo arquiteto ao receber o prêmio Pritzker em 1980 como chave de leitura e compreensão da poética dos espaços projetados por Barragán.

Palavras-chave: Luis Barragán; arquitetura moderna; paisagem; imaginário. 


\section{Abstract}

This dissertation analyzes the architectural production of Luis Barragán recognizing the three phases presented by Mexican historiography (Aníbal Figueroa Castrejón, 1989; Enrique X. de Anda, 1992; and Louise Noelle, 1996). Overviewing the contexts of each phase and analysing representative works of each period. In the first phase studies the González Luna House (1928-1929), in Guadalajara; in the second phase the House-Studio for 4 painters (1939-1941) in Mexico City and the third phase the Jardines del Pedregal (1945-1954); the constructions in Tacubaya (1941-1948) - Casa Ortega, Casa Studio and the Worshop of Luis Barragán and the Chapel and Extension of the Convento f Tlalpan (1953-1960 and 1979-1980) in Mexico City. The research proposed the construction of the imaginary of Luis Barragán through the landscapes mentioned by him, the authors he recognizes in his interlocution, his travels and his speech when receveing the Pritzker Prize in 1980 as a key for reading and understanding the poetic of the spaces designed by Barragán.

Keywords: Luis Barragán; modern architecture; landscape; imaginary. 



\section{Prólogo}

0 caminhar é lento, o silêncio é profundo. Entre as construções de características coloniais, não se distingue de seu entorno. Um olhar atento percebe o contorno de uma abertura dentro de outra abertura no maciço de madeira, o acesso principal. Te recebem em uma espécie de hall, o teto é baixo, e o piso todo recebe pedras vulcânicas cortadas em tamanho preciso, desenhada retícula no piso negro. Outra porta se abre ao interior da construção onde é possível observar o céu. Neste momento de transição entre a vida lá fora, e a vida ali dentro, silêncio. Te orientam um caminho pela lateral do pátio, mais uma porta se abre, um novo e pequeno vestíbulo, um banco de madeira, e as cores já são outras. Se sente como passar por filtros, camadas em direção ao espaço sagrado. A expressão corporal se altera. E de novo, mais uma porta. E de repente, uma sensação de amplitude: com o teto mais alto, a luz se altera. É o vitral por detrás do plano inclinado filtrando a luz que vem lá de fora. 0 ambiente é todo amarelado, âmbar. É possível percorrer a nave, sentar, vivenciar esse espaço. Atrás do altar há um tríptico dourado, e na lateral, uma cruz de madeira solta no espaço. 0 percurso segue guiado: transepto, confessionário, sacristia. Todo o mobiliário é desenhado, fechamentos de madeira vazados separam os ambientes. E ao final do percurso, novamente o pátio: a fonte, o piso de pedra vulcânica, a parede amarela enquadrando o pátio, as buganvílias e o céu. A experiência é única. 


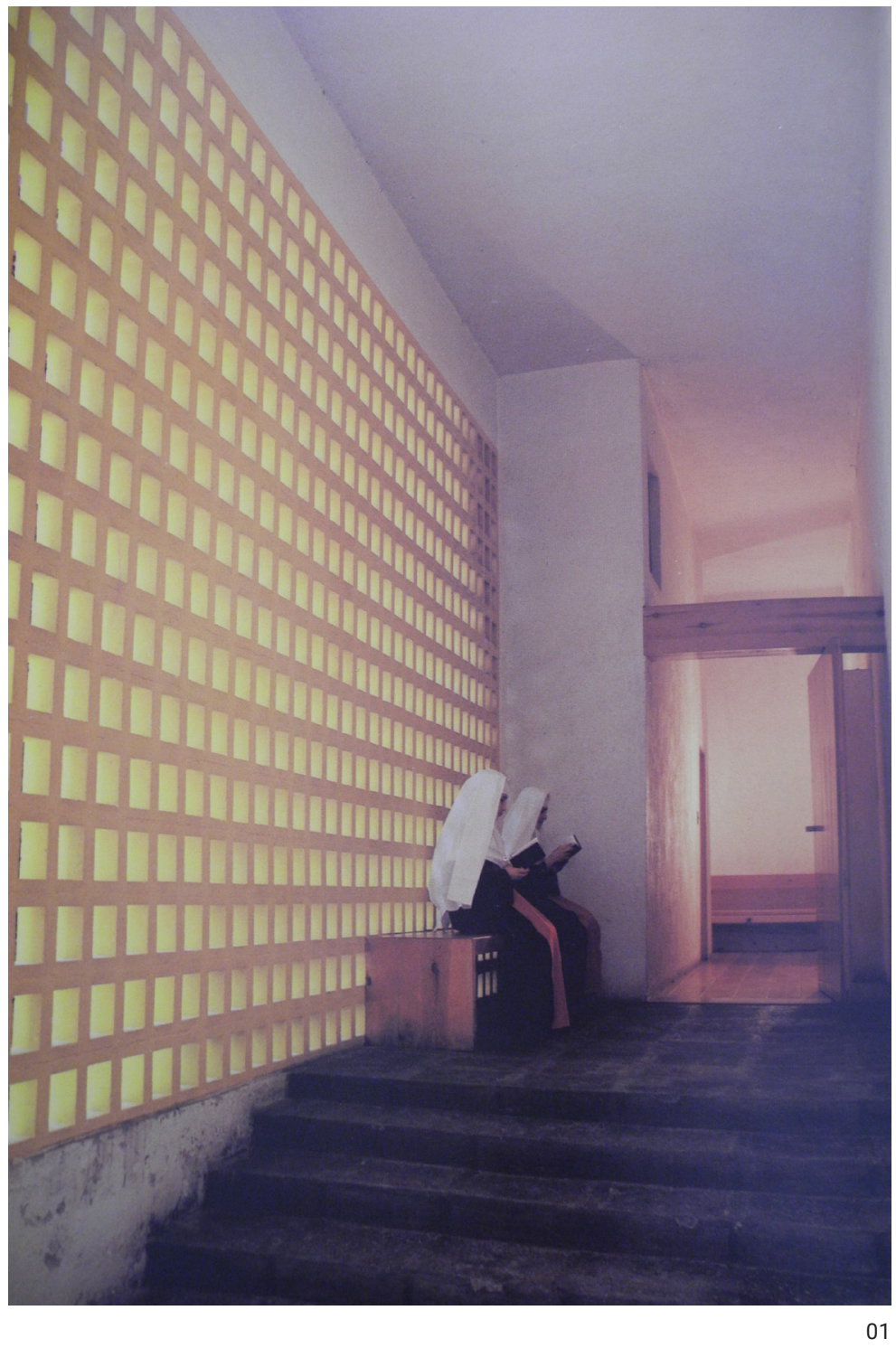




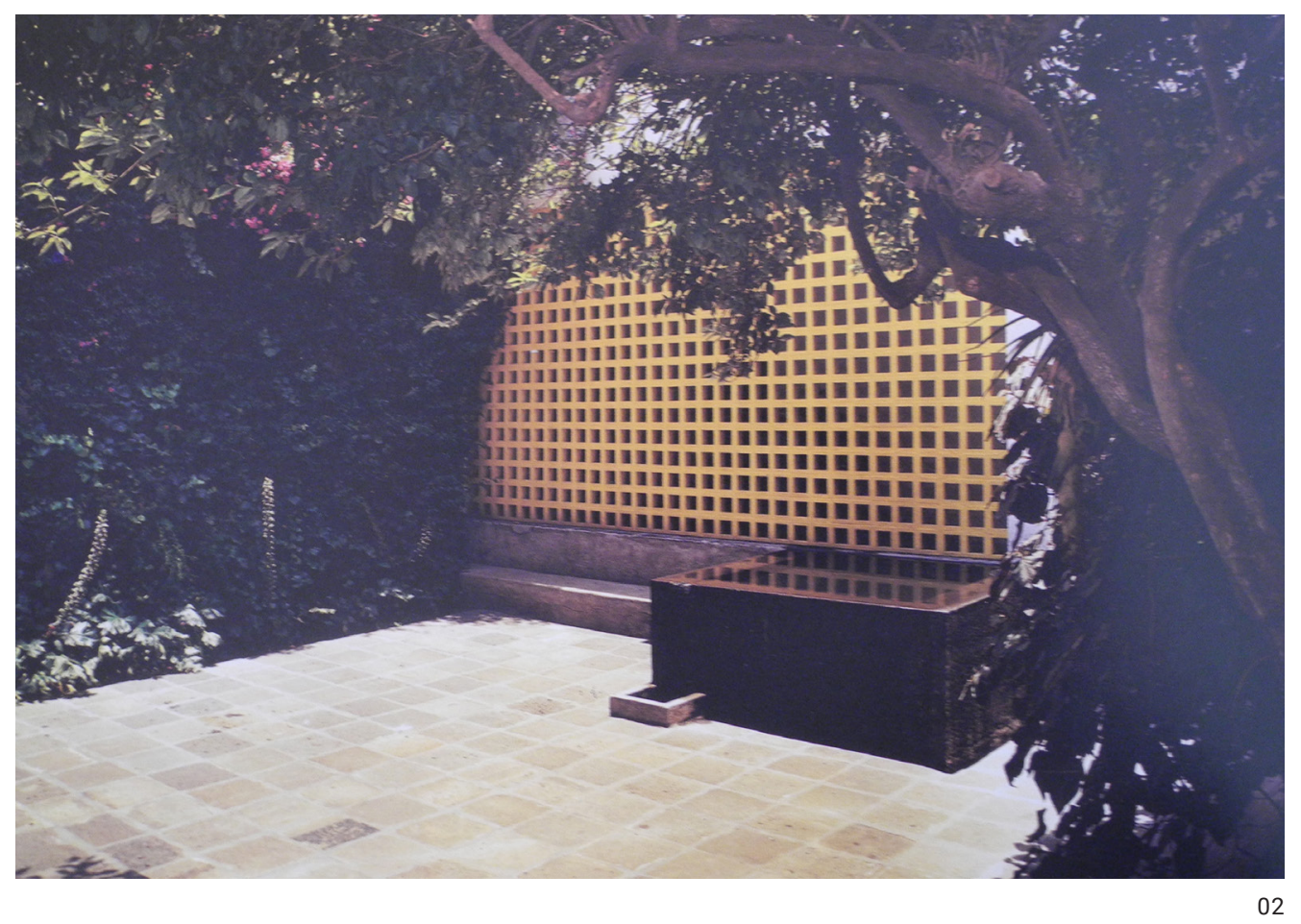




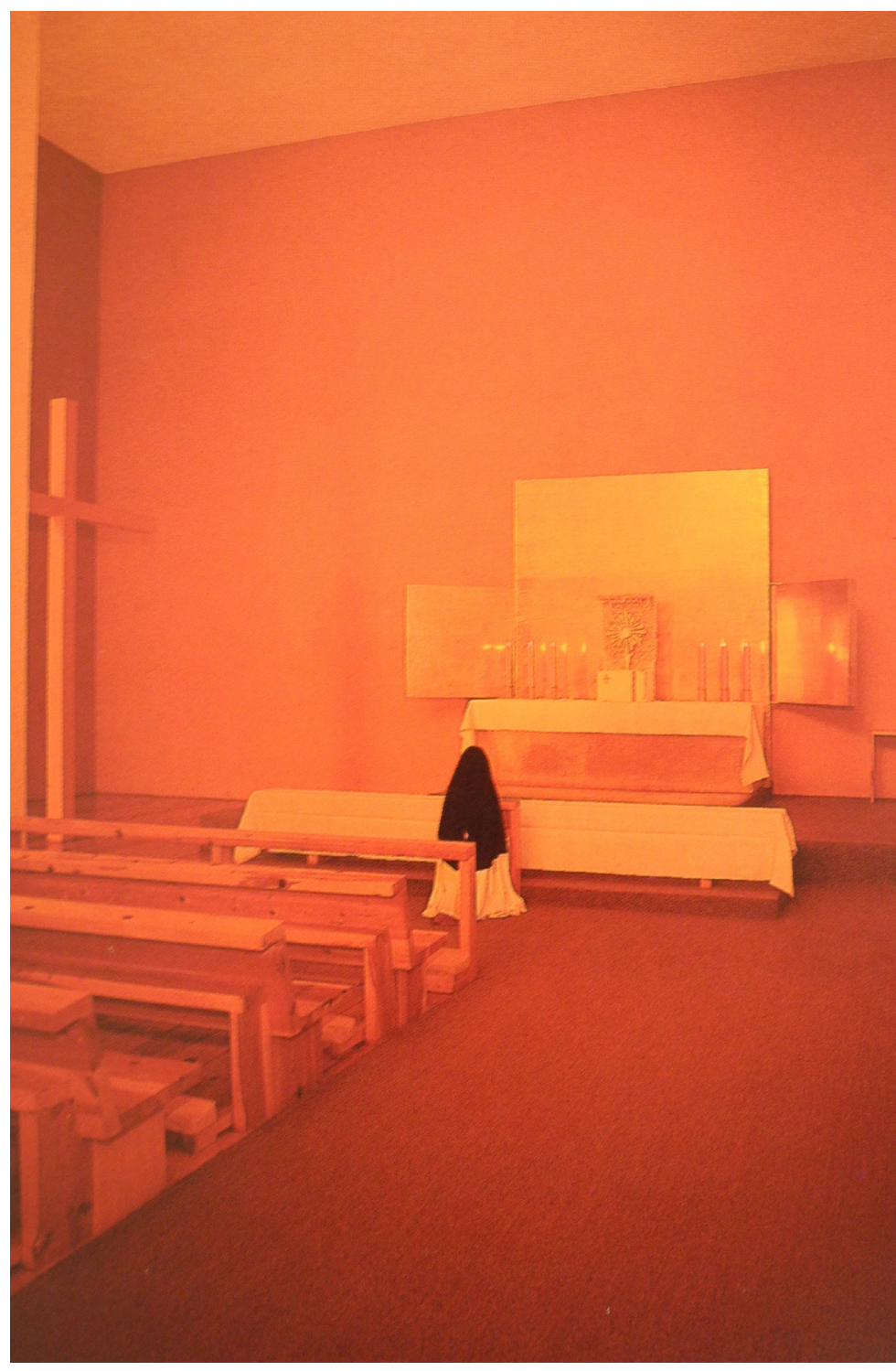




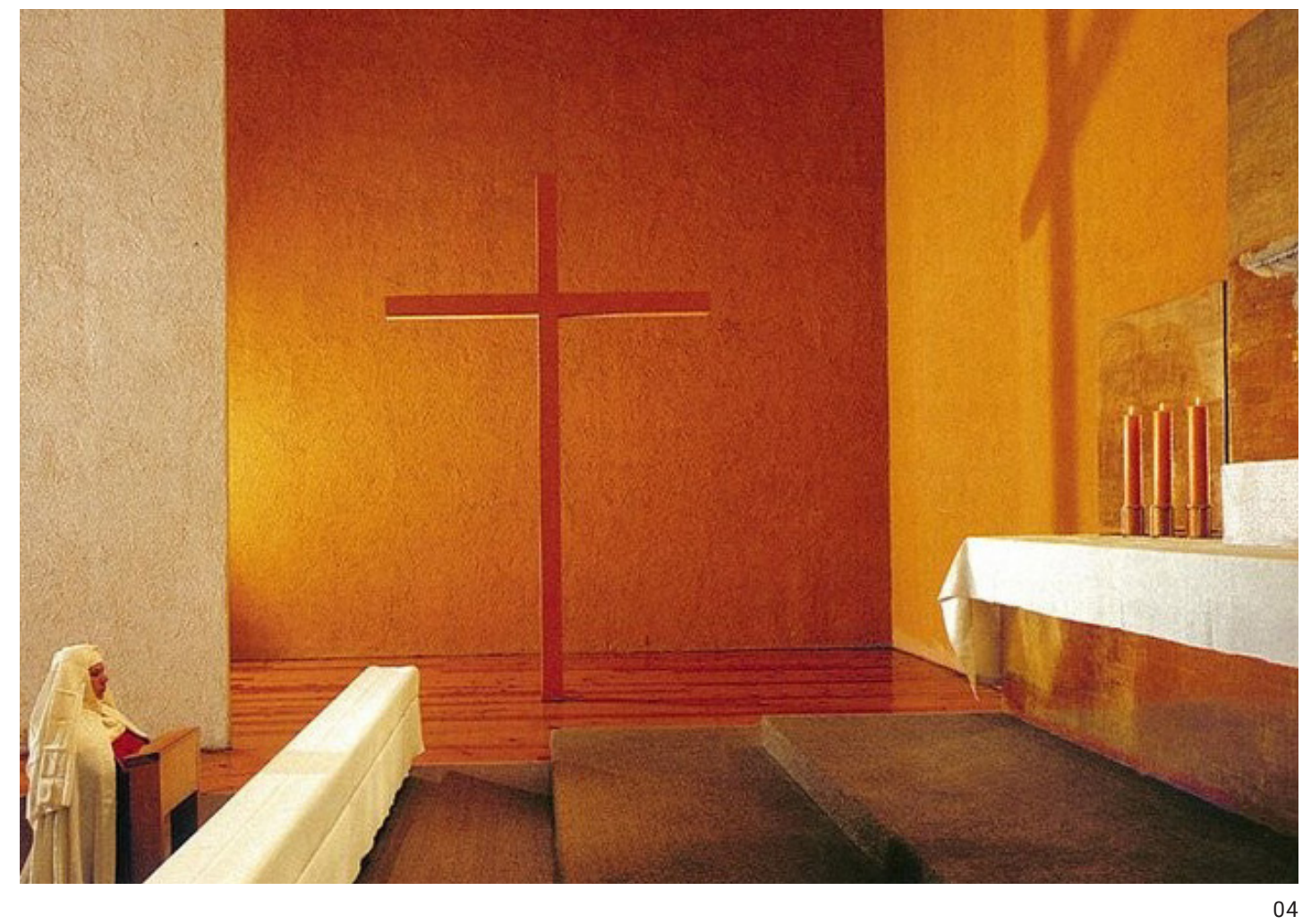




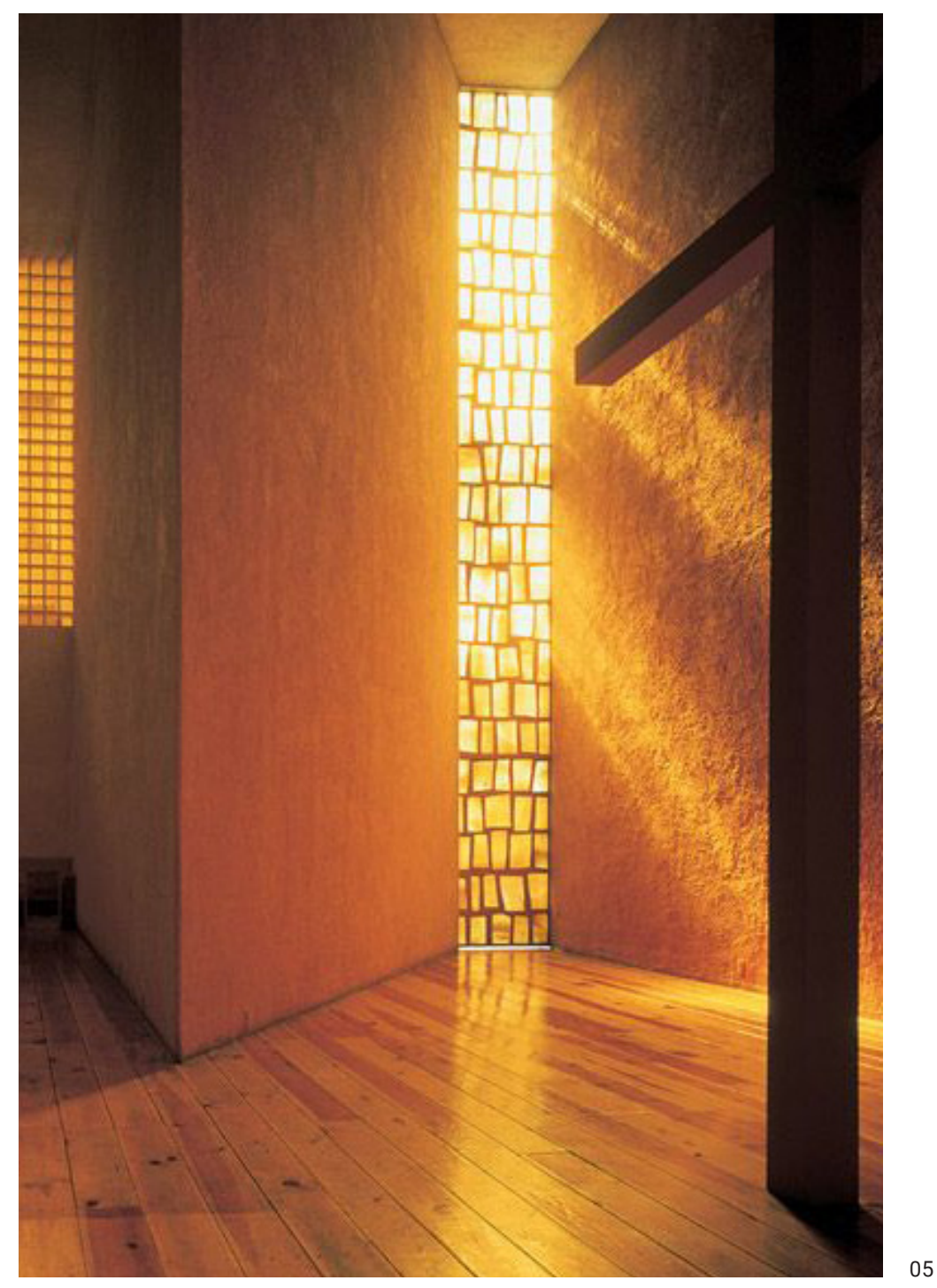




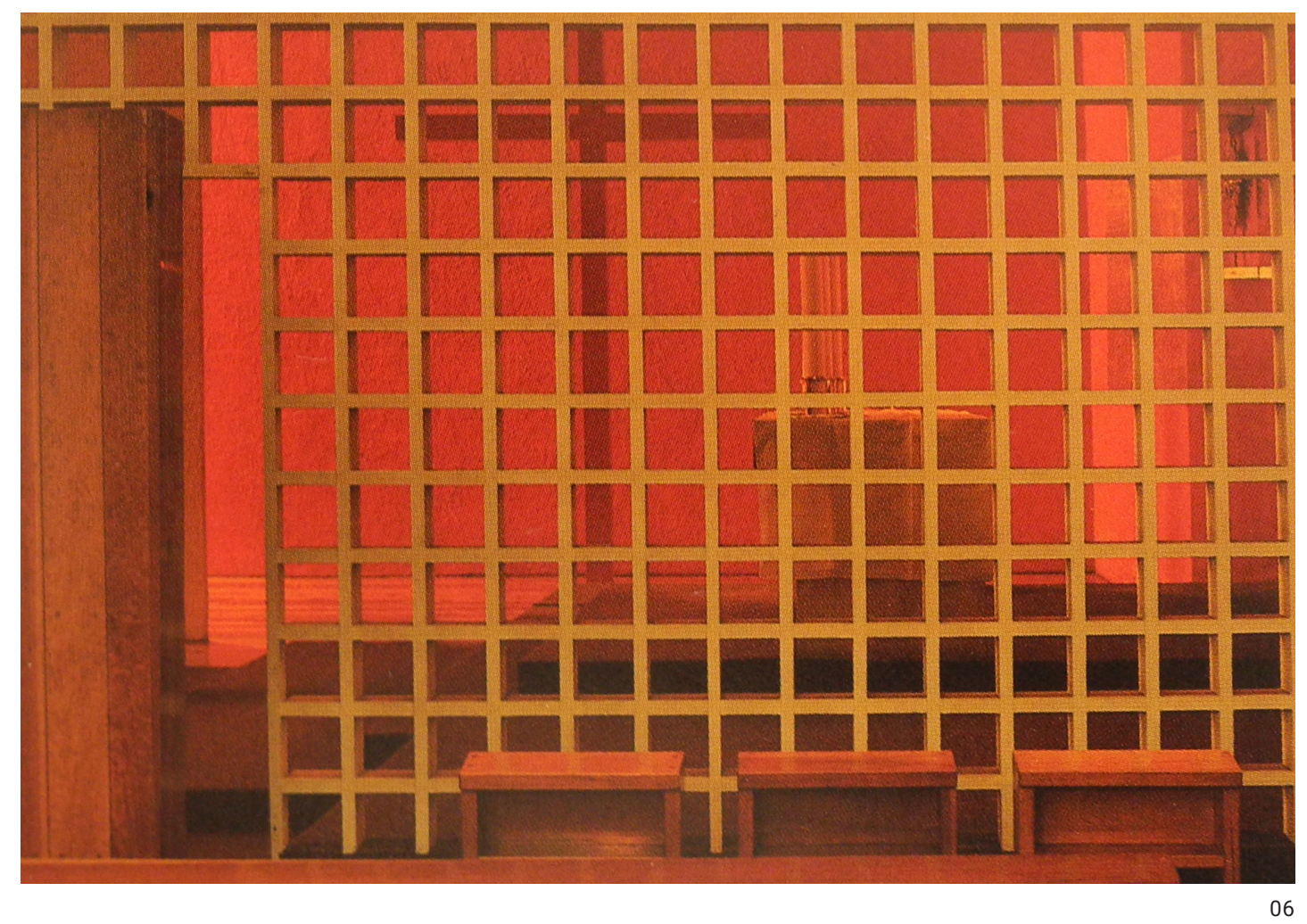




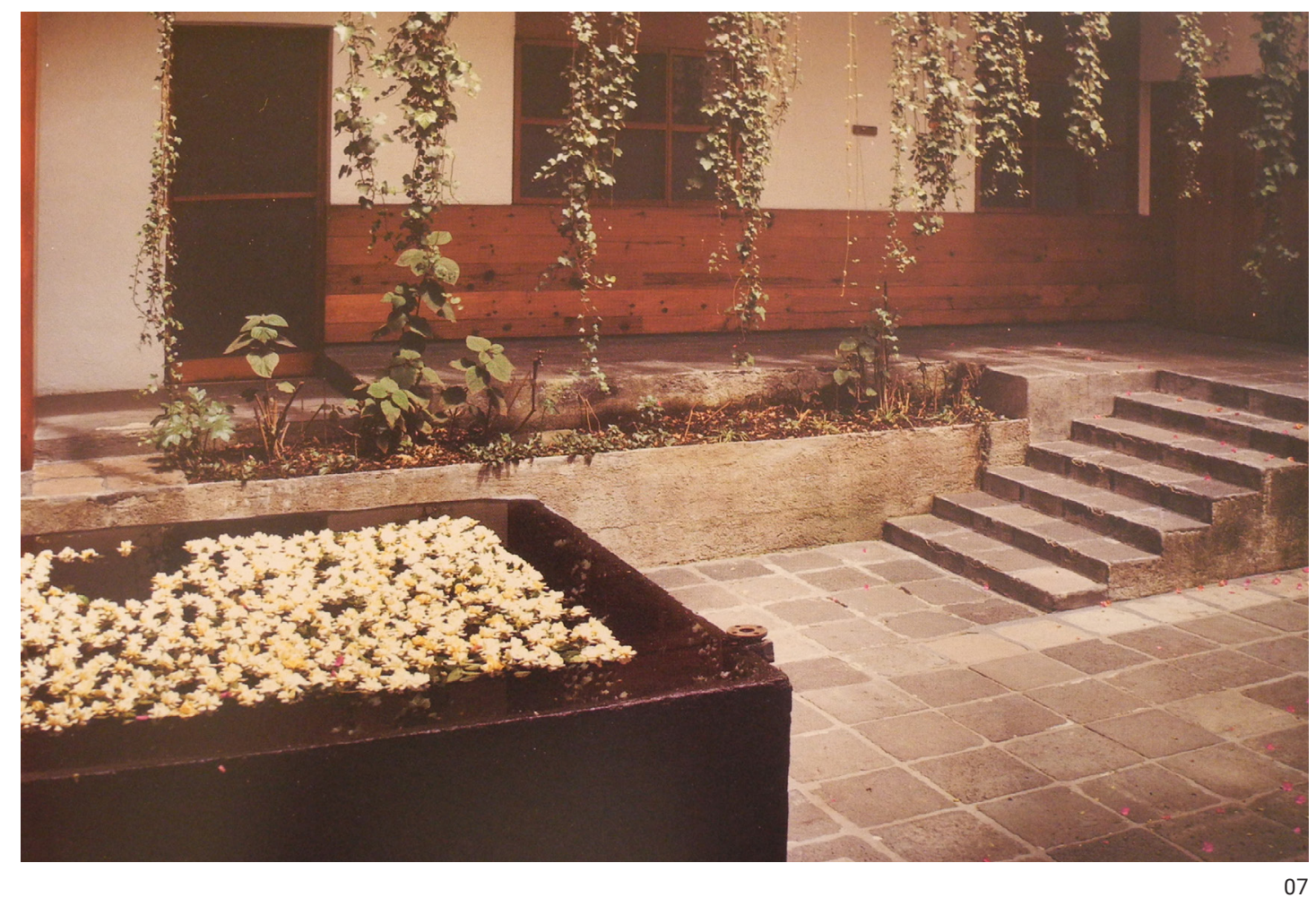




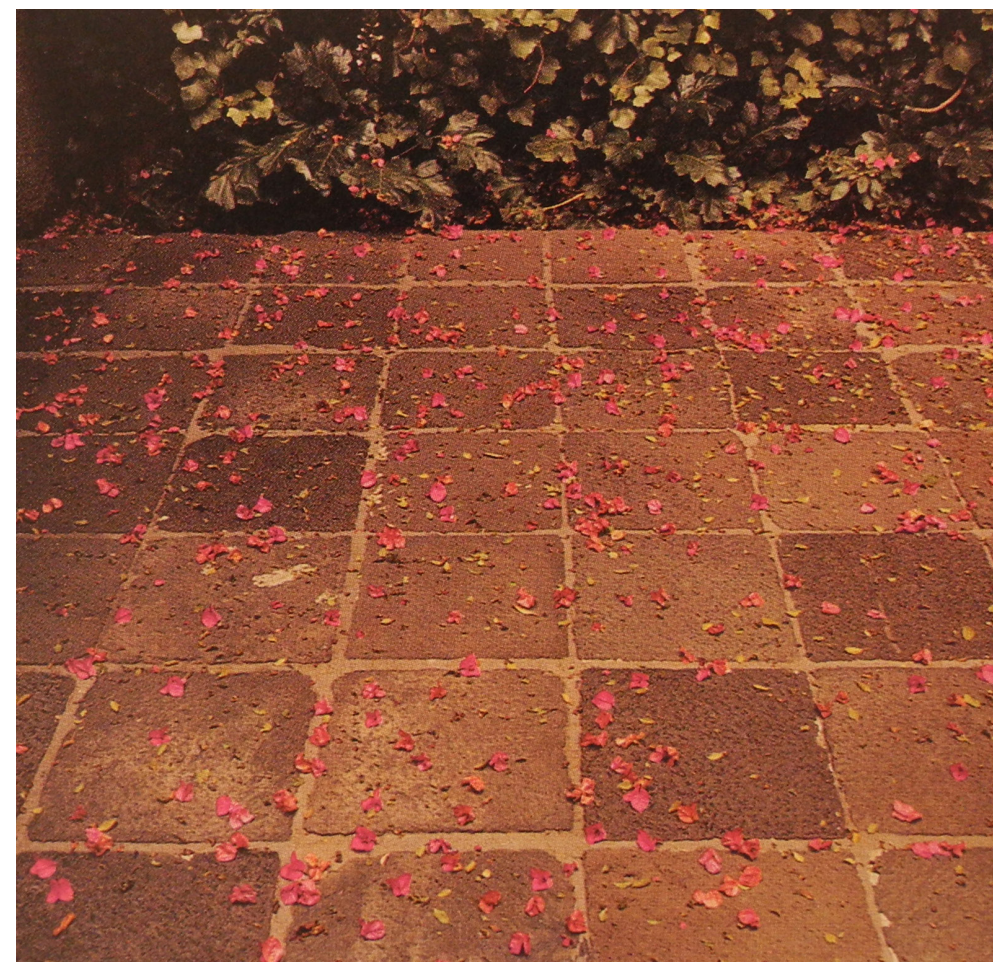


Introdução 
Esta pesquisa discorre sobre a vida e obra do arquiteto mexicano Luis Barragán (1902-1988). Nascido em Guadalajara, passou grande parte da vida na Cidade do México, no período de conformação da arquitetura moderna mexicana. 0 fio condutor desta investigação parte do discurso de Barragán ao receber o prêmio Pritzker ${ }^{1}$ em 1980, no qual foi possível encontrar suas referências artísticas, assim como mapear os lugares por onde percorreu ao longo de sua vida e seus interlocutores. Na cerimônia que aconteceu alguns anos depois de sua exposição individual no MoMA de Nova Iorque em 1976², Luis Barragán reconhece o prêmio como um ato de reconhecimento da própria cultura mexicana. Seu discurso afirma o fazer arquitetura como um trabalho coletivo, agradecendo a colaboração, incentivo e estímulo por parte dos amigos, desenhistas, fotógrafos, escritores e jornalistas que se interessaram em sua obra. Cita Edmundo O'Gorman, Ferdinand Bac, Jesús "Chucho" Reyes e Carlos Pellicer. Discorre sobre os seguintes temas apresentados no discurso: "religião e mito, beleza, silêncio, solitude ${ }^{3}$, serenidade, alegria, a morte, jardins, fontes, arquitetura, a arte de ver e nostalgia" (BARRAGÁN, 1980, p. 58-61), apresentando algumas reflexões, recordações e impressões que, em seu conjunto, expressam a ideologia que sustenta seu trabalho. Leu trechos do poema de Carlos Pellicer ${ }^{4}$, brindando a todos sobre a importância da arte de ver (BARRAGÁN, 1980, p. 58). Recebe o prêmio por considerarem a sua arquitetura como um ato sublime da imaginação poética, conforme ata do júri:

We are honoring Luis Barragán for his commitment to architecture as a sublime act of the poetic imagination. He has created gardens, plazas, and fountais of haunting beauty metaphysical landscapes for meditation and companionship. ${ }^{5}$

A pesquisa alinha-se à historiografia mexicana identificada nos escritos de Aníbal Figueroa Castrejón, Enrique X. de Anda e Louise Noelle, situando a produção arquitetônica de Barragán em três momentos (e nos termos dos três autores): período arquitetura tapatía conformado pelas primeiras obras em Guadalajara e arredores entre 1927-1935 (CASTREJÓN, 1989); período funcionalista conformado pelas obras na Cidade do México entre 1936-1944 (CASTREJÓN, 1989; ANDA, 1992; NOELLE, 1996) e arquitetura emocional (CASTREJÓN, 1989; NOELLE, 1996) conformada pela produção arquitetônica a partir de $1945^{6}$.

Em uma entrevista em 1981 a Jorge Salvat, originalmente publicada na revista italiana Modo, Barragán responde a seguinte pergunta: "Como definiria seu método de trabalho? - Me baseio muito na intuição e nas observações efetuadas a partir
1. Luis Barragán foi o segundo arquiteto a receber o prêmio Pritzker pelo reconhecimento de sua arquitetura como um ato sublime da imaginação poética. Foi laureado em 1980 com juri composto por J. Carter Brown (presidente), Lord Clark de Saltwood, Arata Isozaki, Philip Johnson, J. Irwin Miller, Cesar Pelli, Carleton Smith (secretário) e Arthur Drexler (consultor) e recebeu uma escultura Henry Moore.

2. A exposição foi concebida pelo arquiteto argentino Emílio Ambasz.

3. Solitude s.f. solidão como define Houaiss Dicionário da Língua Portuguesa.

4. Por la vista el bien y el mal

Nos llegan.

Ojos que nada ven, Almas que nada esperan

5. Estamos honrando a Luis Barragán por seu compromisso com a arquitetura como um ato sublime da imaginação poética. Ele criou jardins, praças e fontes de beleza assombrosa - paisagens metafísicas para meditação e companheirismo. (tradução da autora).

6. Ver as publicações: "El período funcionalista de Luis Barragán: los años heroicos". CASTREJÓN, Aníbal Figueroa. In: "Luis Barragán 1990 Historia de um debate". ANDA, Enrique X.de. México: UNAM, 2016; "Luis Barragán: Clásico del Silencio". ANDA, Enrique de X. Bogotá: Escala, 1992 e "Luis Barragán. Búsqueda y creatividad". NOELLE, Louise. México: UNAM, 1996. 
de minhas leituras e minhas viagens" (BARRAGÁN, 1981, p. 128). Seguindo essas pistas, a pesquisa orienta-se no aprofundamento das três fases do arquiteto, contextualizando as obras, aproximando as viagens realizadas pelo arquiteto e a relação entre seus interlocutores para a compreensão de seu discurso e produção ao longo de toda a sua trajetória. Para tanto, além de ampla pesquisa bibliográfica e entrevistas, foram feitas visitas às obras (na Cidade do México em fevereiro de 2016, em Guadalajara e arredores, e novamente na Cidade do México em setembro de 2017), e o redesenho de todas as peças gráficas referentes aos projetos.

Esta dissertação está dividida em três capítulos condizentes a cada etapa, seguindo sequência cronológica, abordando os contextos históricos, políticos, econômicos, sociais e culturais de cada etapa, identificando as matrizes que direcionaram Barragán e propondo alguns cruzamentos entre a produção de outros arquitetos, artistas e fotógrafos. Aprofunda-se em obras representativas de cada etapa, reconstruindo essas paisagens nos dias atuais. Este universo iconográfico conforma a construção do imaginário de Luis Barragán e propõe alguns atravessamentos, reconhecendo as inter-relações entre contexto e obra, e seus interlocutores. Este imaginário que é possível construir a partir do que ele aponta, e que é possível perceber através das pessoas que ele conviveu. 0 uso das imagens se faz como expressão visual na construção de uma narrativa.

No primeiro capítulo, Primeira Fase (1927-1935), desenvolve-se o período correspondente à primeira fase retomando as paisagens da infância, o rancho da família em Jalisco, o mundo rural, a dimensão cromática dessa paisagem, as construções vernáculas, de modo geral, a cultura onde é formado. Como paisagem paralela entram as fotografias de Juan Rulfo, contemporâneo e conterrâneo de Luis Barragán. Abordam-se os contextos históricos e culturais nos anos da formação do arquiteto, no México e em Guadalajara especificamente, identificando as correntes culturais e arquitetônicas. Em sua primeira viagem à Europa, Barragán se depara pela primeira vez com arquitetura moderna através dos pavilhões vanguardistas de Le Corbusier e de Konstantin Melnikov e da exposição de Frederick Kiesler na Exposição de Artes Decorativas em Paris (Exposition Internationale des Arts Decoratifs et Industrials Modernes) em 1925. Nesta viagem visita a França, a Espanha, a Itália e a Grécia e toma contato com as ilustrações de Ferdinand Bac. Apresenta-se o conjunto de obras projetadas e construídas em Guadalajara entre 1927-1935 e aprofunda-se na Casa González Luna, 1928-1929.

No segundo capítulo, Segunda Fase (1936-1944), abordam-se os deslocamentos realizados por Barragán entre 1936-1944, as viagens à Chicago e Nova lorque e o retorno à Europa; a influência de Le Corbusier; o contexto cultural e arquitetônico no México deste período e suas distintas vertentes; o deslocamento de Guadalajara à Cidade do México; o conjunto de obras realizadas no bairro de Cuauhtémoc na Cidade do México. Ao chegar na Cidade do México e se deparar com uma cidade em expansão, Barragán enfrenta o tema da habitação coletiva nos centros urbanos e projeta e constrói uma série de edifícios. Esse conjunto de obras foi pouco registrado à sua época. Essas obras não entraram na exposição do MoMA em 1976 e nem na exposição monográfica no Museu Rufino Tamayo em 1985. No entanto, este período de intensa atividade do arquiteto e de grande transformação em relação à sua produção é de extrema importância. Faz-se análise da Casa-Estúdio 
para Quatro Pintores realizado em colaboração com Max Cetto entre 1939-1941. Assimilam-se suas vivências e produção arquitetônica colocando em debate o pensamento e obra correspondente à sua segunda fase.

No terceiro capítulo, Terceira Fase (a partir de 1945), aponta-se o contexto histórico nos anos 1940 e 1950 no México (o chamado período heroico na arquitetura mexicana); a construção da Cidade Universitária, uma das obras mais emblemáticas na conformação do México moderno que reuniu mais de 60 arquitetos mexicanos; a relação e contribuição dos artistas Jesús "Chucho" Reyes e Mathias Goeritz na obra de Luis Barragán a partir meados da década de 1940. Aborda-se a viagem ao norte da África realizada pelo arquiteto em 1953. Faz-se a reflexão sobre suas obras arquitetônicas em distintas escalas: do desenho da casa à construção da paisagem urbana, são elas: Jardines del Pedregal de 1945-1954; as construções em Tacubaya, de 1941 a 1948 e a Capela e Ampliação do Convento de Tlalpan, 1953-1960 e 1970-1980.

Algumas considerações devem ser mencionadas acerca das publicações referentes à obra de Luis Barragán. Apesar da exposição do MoMA em 1976 ter sido de grande relevância para a difusão e reconhecimento de sua obra ${ }^{7}$, já na década de 1930 a obra de Luis Barragán apareceria em publicações da revista The Architectural Record. Posteriormente seus projetos foram publicados nas revistas norteamericanas House and Garden, Design, House Beautiful e Liturgical Arts, nas revistas italianas Domus e Casabella ${ }^{8}$, e nas revistas mexicanas Arquitectura y Decoración e Arquitectura México. A norte-americana Esther Born publicou "The New Architecture en México" 9 em 1937 incluindo o Parque Revolución, projeto de Luis Barragán junto com seu irmão José Juan, em Guadalajara, de 1934 e as primeiras obras na Cidade do México: Casa calle Río Guadiana, 1936 e Duas Casas Av. Amsterdam, 1936. A partir de 1980, a obra do arquiteto foi publicada em diversos meios, e a revista Artes de México publicou em 1994 um volume especial em homenagem à Barragán ${ }^{10}$.

Um ano após a morte do arquiteto, o Colégio de Arquitetos da Cidade do México e a Sociedade de Arquitetos Mexicanos (CAM-SAM) iniciaram o Programa Luis Barragán CAM/SAM 1989, coordenado Enrique X. de Anda com o intuito de promover eventos e atividades a nível nacional relacionadas com a obra do arquiteto (ANDA, 2012, p.32). A partir deste programa se desdobraram: a publicação do livro Luis Barragán: clásico del silencio, em 1989 e o Simpósio Internacional em 1990, ambos organizados por Enrique X. de Anda. Tais eventos trouxeram à luz a reflexão crítica da produção arquitetônica de Barragán. Para o Simpósio, foi feita uma convocatória a arquitetos, críticos e historiadores, que promoveram debates através de três grandes temas: nacionalismo; valores plásticos e espaciais; e história e tradição. Os textos deste simpósio foram publicados pela UNAM anos

7. A exposição consistia em uma série de projeções em grande formato de fotografias nas paredes de uma pequena sala do museu e catálogo da exposição (ZANCO, 2012, p. 24).

8. A este respeito ver revistas: "Mexican Villas. Luis Barragán Architect", The Architectural Record, número 3 , vol. 70, setembro de 1931; “Children's Park. Parque de la Revolución. Designed by Luis Barragán architect, Juan Luis Barragán civil engineer" The Architectural Record, número 3 , vol. 78, setembro de 1935 . "Modernist Houses in Mexico. Designed by Luis Barragán", House and Garden, outubro de 1931 Domus 280, março 1953; Domus 321, agosto 1956; Domus 468, novembro 1968; Domus 611, novembro 1980; Domus 781, abril 1996; Domus 899, janeiro 2017.

9. "Park of the Revolution Luis Barragán architect, Juan Luis Barragán civil engineer", "Speculation House. Luis Barragán architect"; "Two-family house in Mexico City. Luis Barragán architect" The Architectural Record, número 4 , vol. 81 , abril de 1937.

10. "En el mundo de Luis Barragán", Artes de México. México, primavera de 1994 
depois, em 2016, organizados também por Enrique X. de Anda e conta com a compilação de diversos textos críticos colocando Barragán em debate.

Alguns anos após a morte de Raúl Ferreira"11 em 1995, o arquivo profissional de Luis Barragán foi adquirido por uma galeria de Nova lorque. Em 1996, o arquivo foi comprado por Rolf Fehlbaum (Fundação Vitra) e sua esposa, Federica Zanco idealizou a Barragán Foundation com sede em Birsfelden na Suíça. A Fundação, responsável pela preservação do arquivo, mantém todos os direitos autorais sobre a obra de Luis Barragán e recusou o acesso ao arquivo para a realização desta

11. Raúl Ferreira (1942-1992) foi sócio de Barragán entre 1964 e 1972 (ZANCO, 2002, p. 22). pesquisa. 0 arquivo pessoal de Luis Barragán encontra-se na Fundación Barragán localizada na Casa Estúdio Barragán, na Cidade do México, onde tive acesso, ainda que restrito, aos postais, cartas, revistas e fotografias de Luis Barragán consultadas em setembro de 2017. 


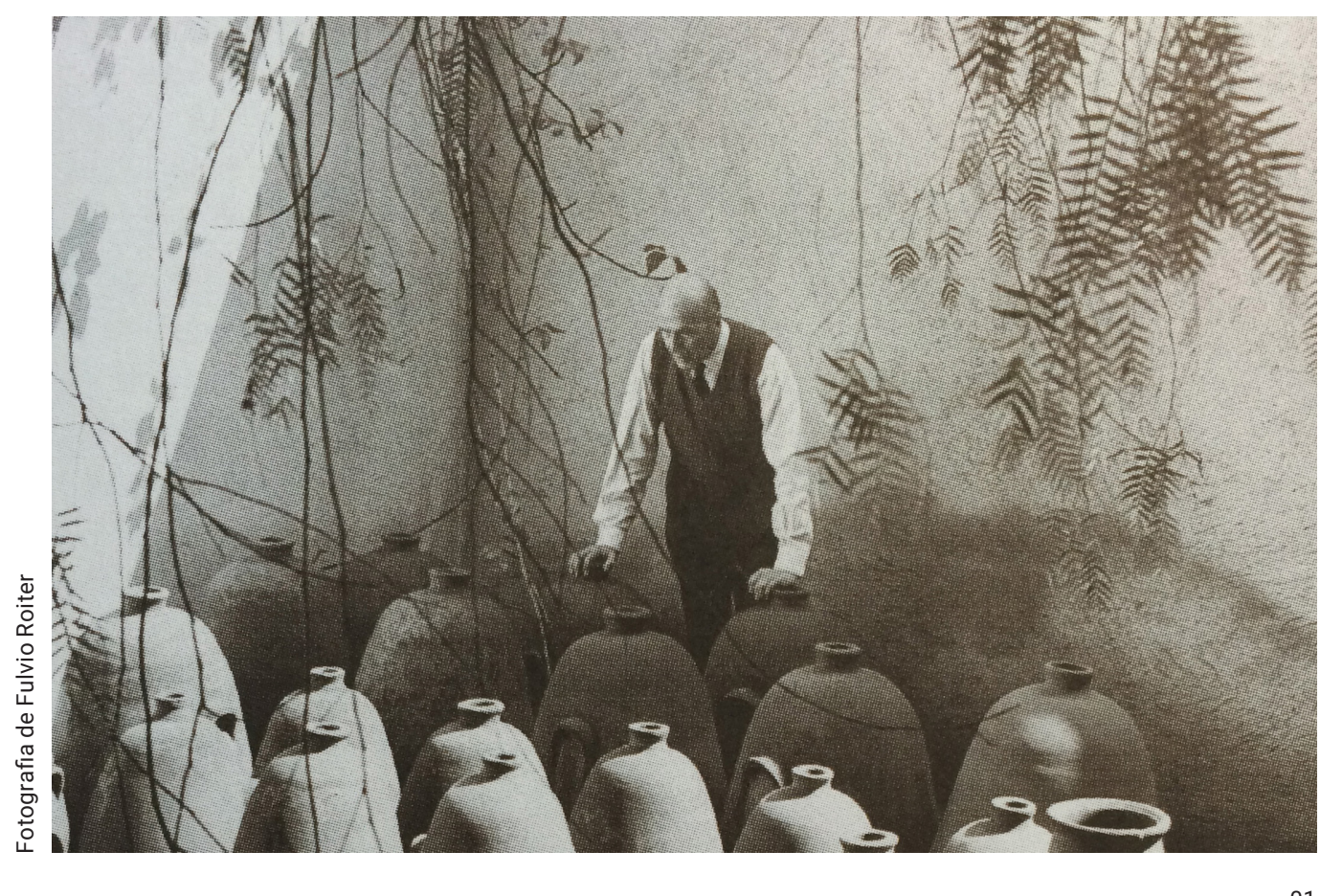


1. Primeira fase 1927-1935 
1.1 Mapas

Las primeras memorias de mi infancia están relacionadas con un rancho que tenía mi familia en las proximidades de Mazamitla. Era un pueblo rodeado de montañas y formado por casas que tenían techo de teja e inmensos aleros, para proteger a los habitantes de las lluvias que caen en esa región. Hasta el color de la tierra era un color interesante: tierra roja es de la región. En ese pueblo el sistema de distribución de agua era a base de troncos ahuecados en forma de canales, a su vez sostenidos por horquetas de palo, semejantes a trinches, a una altura de cinco metros por encima de los techos. Este acueducto cruzaba todo el pueblo y alcanzaba los patios, donde había grandes fuentes de piedra para recibir el agua. Los patios albergaban los establos con vacas y pollos, todos juntos, y afuera, en la calle, había argollas en las fachadas de las casas para amarrar a los caballos. Los troncos acanalados estaban cubiertos de musgo y, obviamente, dejaban escapar el agua, la cual escurría por toda la ciudad, lo cual le daba al pueblo un ambiente y un aire de cuento de hadas. No, de eso no conservo fotografías, solamente lo tengo archivado en mi memoria. (BARRAGÁN, 1976, p. 103 e 104) ${ }^{1}$ 
Retomar a memória é uma prática recorrente de Luis Barragán. Muitas de suas paisagens da infância, tais como a fazenda Corrales de sua família, as construções dos povoados mexicanos e sua matéria, a paisagem de Jalisco, lugar onde nasceu, transparecem nos traços de sua produção. Jalisco é marcada por uma geografia acidentada, com montanhas, rios, lagos, caminhos, percursos e pedras vulcânicas espalhadas na paisagem. Elementos urbanos encontrados nos povoados, não apenas no estado de Jalisco, mas também em seus arredores, como Michoacán, com fontes de água marcadas na paisagem, por exemplo, chamam a sua atenção:

[...] en Páztcuaro, ciudades dónde uno encuentra la atracción del recorrido al pasear por entre calles que se abren a plazas con árboles y fuentes que aumentan el sentido de la belleza. (BARRAGÁN, 1951, p. 39)²

As paisagens mencionadas por ele, o casario dos povoados com suas paredes grossas, acabamentos rústicos e o uso de telha de barro são elementos arquitetônicos tradicionais que aparecem com recorrência na arquitetura de Luis Barragán. Suas preocupações percorriam este universo íntimo que pertencia à sua infância: o cheiro da madeira molhada, o reflexo das copas das árvores na represa, as cores das flores, as construções coloniais e suas as paredes pintadas com cal, os pátios internos das casas.

Paisagens memoráveis e que se pode reconhecer também, por exemplo, através das fotografias de Juan Rulfo (1918-1986), escritor e fotógrafo, contemporâneo de Luis Barragán e conterrâneo de Jalisco que permite que se veja essa paisagem tanto em sua obra literária, quanto fotográfica. Essa paisagem, as construções, seus costumes, seus significados simbólicos traduzidos em textos e fotografias. Muitas das quais nos ajudam a reconhecer as paisagens mencionadas por Barragán. Uma elaboração poética que surge a partir do lugar. Homens da mesma época, vivendo no mesmo país e com temas convergentes ${ }^{3}$.

Mas se Barragán convoca o passado, o faz a partir do presente, pois ao mesmo tempo em que busca uma narrativa a partir do passado, se mantém atento à vida moderna e reinventa as suas próprias bases para poder projetar:

En mi trabajo subyacen los recuerdos del rancho de mi padre, donde pase años de mi niñez y adolescencia, y en mi obra siempre he luchado por adaptar a las necesidades de la vida moderna la magia de esas lejanas añoranzas, de aquellos remotos y nostálgicos años. (BARRAGÁN, 1980, p. 60) ${ }^{4}$

Ao fazê-lo remete as paisagens de Jalisco de seu momento da infância. Tanto Luis Barragán quanto Juan Rulfo ao olharem para este legado o fazem com o enquadramento do moderno.
1. "As primeiras memórias de minha infância estão relacionadas com um rancho que tinha a minha família nas proximidades de Mazamitla. Era um povoado rodeado de montanhas e formado por casas que tinham teto de telha e imensos beirais para proteger os habitantes das chuvas que caem nessa região.

Até a cor da terra era uma cor interessante: terra vermelha é a da região. Nesse povoado o sistema de distribuição de água era a base de troncos com ocos em forma de canais, em sua vez sustentados por pedaços de pau, semelhantes à tridentes, em uma altura de cinco metros acima dos tetos. Este aqueduto cruzava todo o povoado e alcançava os pátios, onde haviam grandes fontes

de pedra para receber a água. Os pátios abrigavam os estábulos das vacas e galinhas, todos juntos, e fora, na rua, haviam argolas nas fachadas das casas para amarrar os cavalos. Os troncos acanalados estavam

cobertos de musgo e, obviamente, deixavam escapar a água, a qual escorria por toda a cidade, na qual dava ao povoado um ambiente com um

ar de conto de fadas.

Não, disto não conservo

fotografias, apenas tenho arquivado em minha

memória". (BARRAGÁN

1976, p. 103 e 104 tradução da autora)

2. "[...] como em

Páztcuaro, cidades onde se pode encontrar a atração do percurso ao passear entre ruas que se abrem em praças com árvores e fontes que aumentam o sentido da beleza”. (BARRAGÁN, 1951, p. 39, tradução da autora).

3. A proximidade hoje muito evidente entre Luis Barragán e Juan Rulfo não resultou de um contato e de trocas pessoais.

4. "Em meu trabalho subjazem as lembranças do rancho do meu pai, onde passei anos de minha infância e adolescência, e na minha obra sempre lutei por adaptar as necessidades da vida moderna à magia dessas saudades distantes, daqueles remotos e nostálgicos anos". (BARRAGÁN 1980 , p. 60 , tradução da autora). 

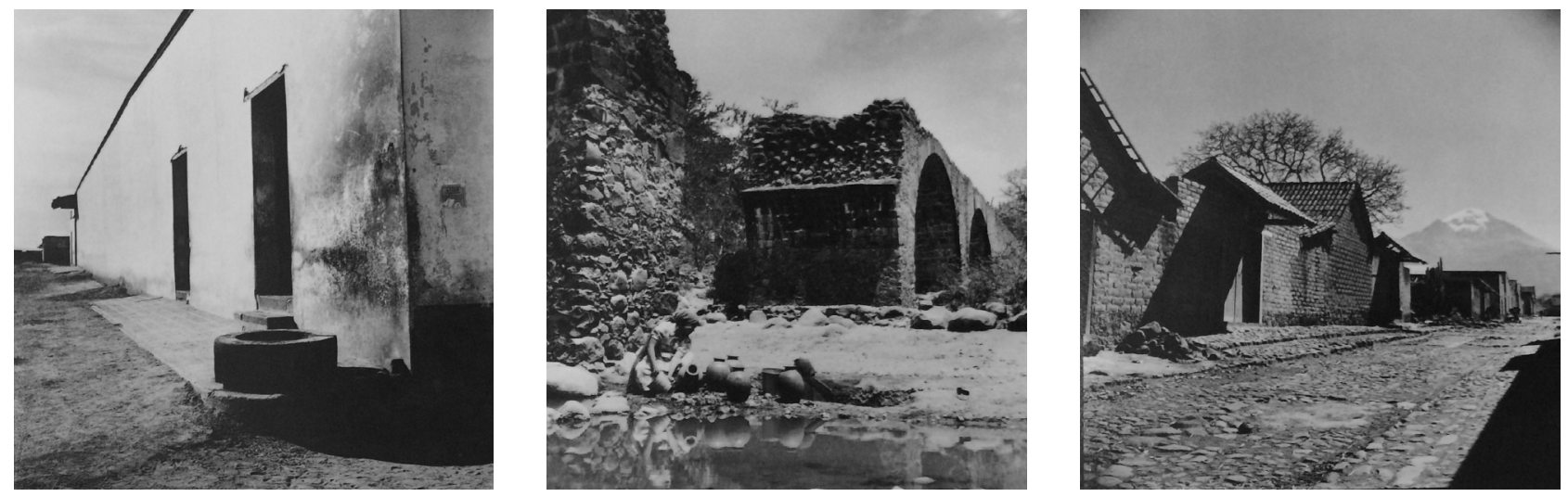

01
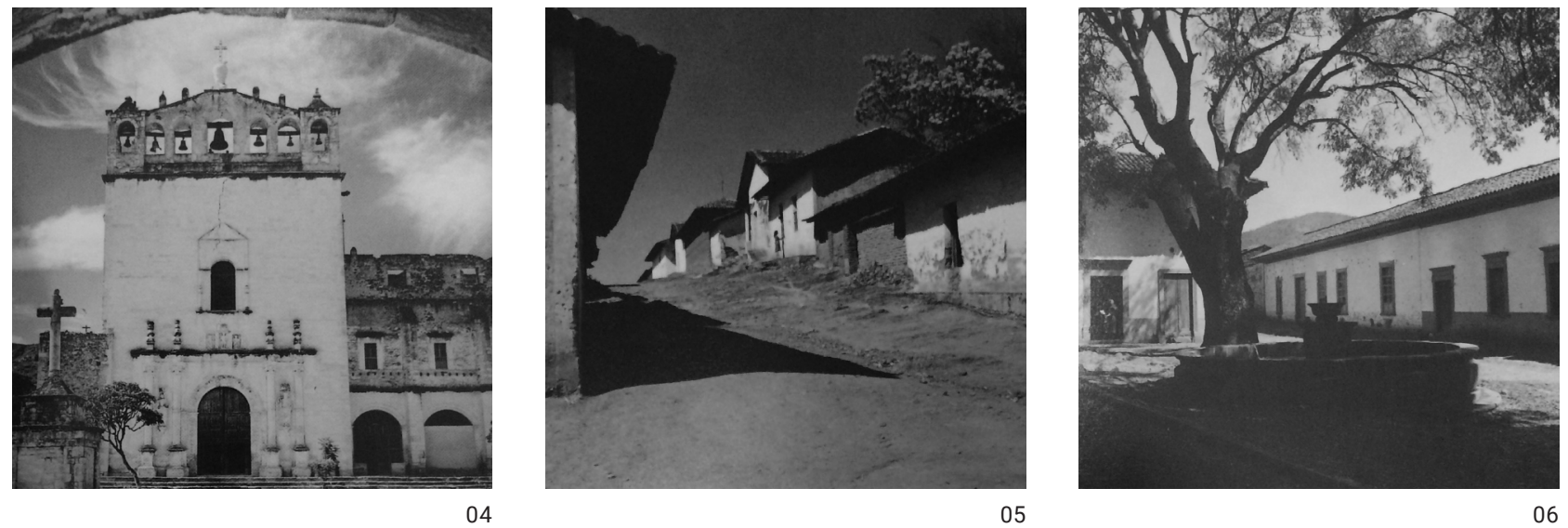

01. Mexicaltzingo, 1960

02. Puente de Apulco en ruinas, $\mathrm{s} /$ data

03. Pueblo del altiplano y Popocatépetl, s/data

04. Fachada del templo de Metztitlán, 1950

05. Calle de un pueblo, s/data

06. Calle de Pátzcuaro, s/data 


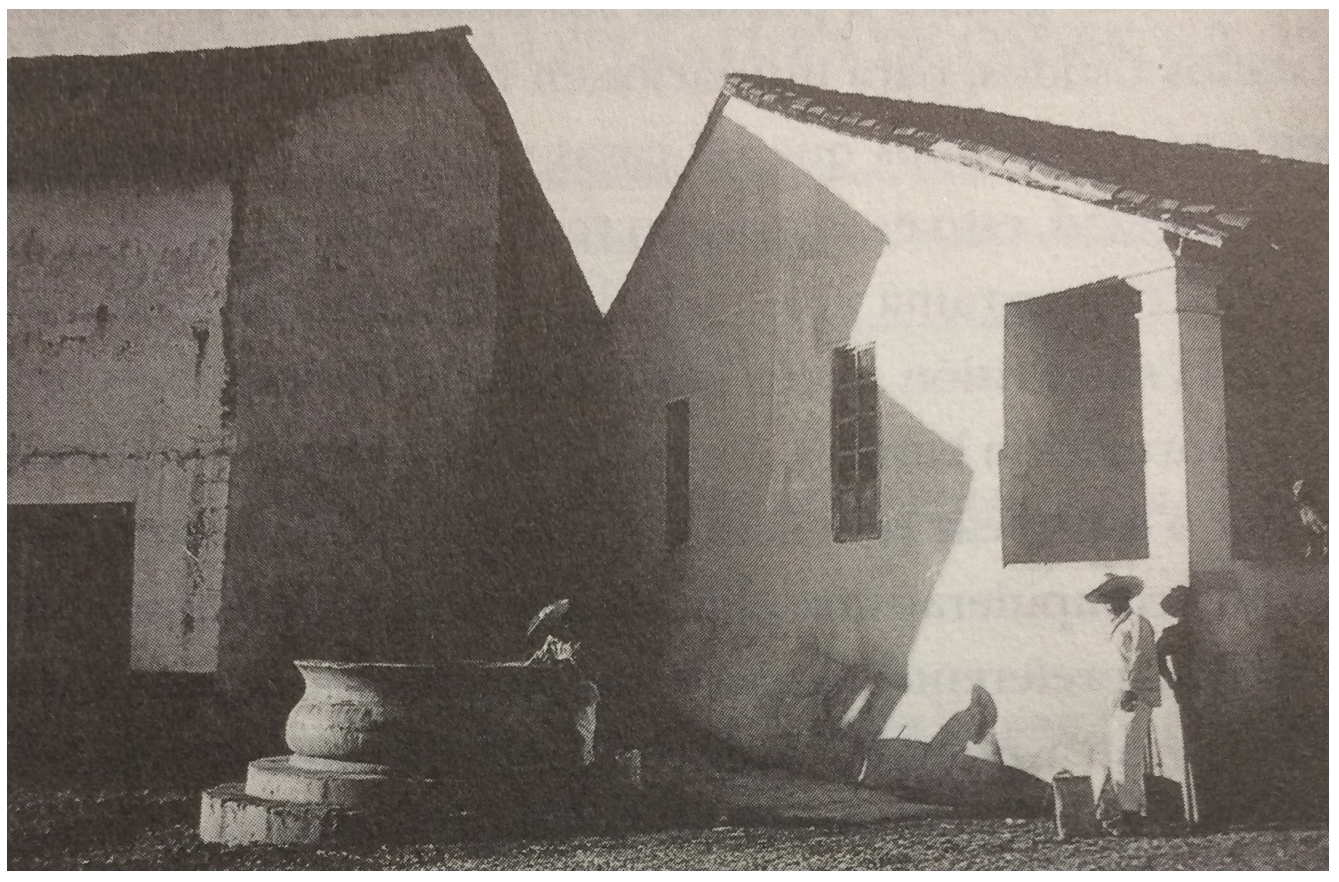




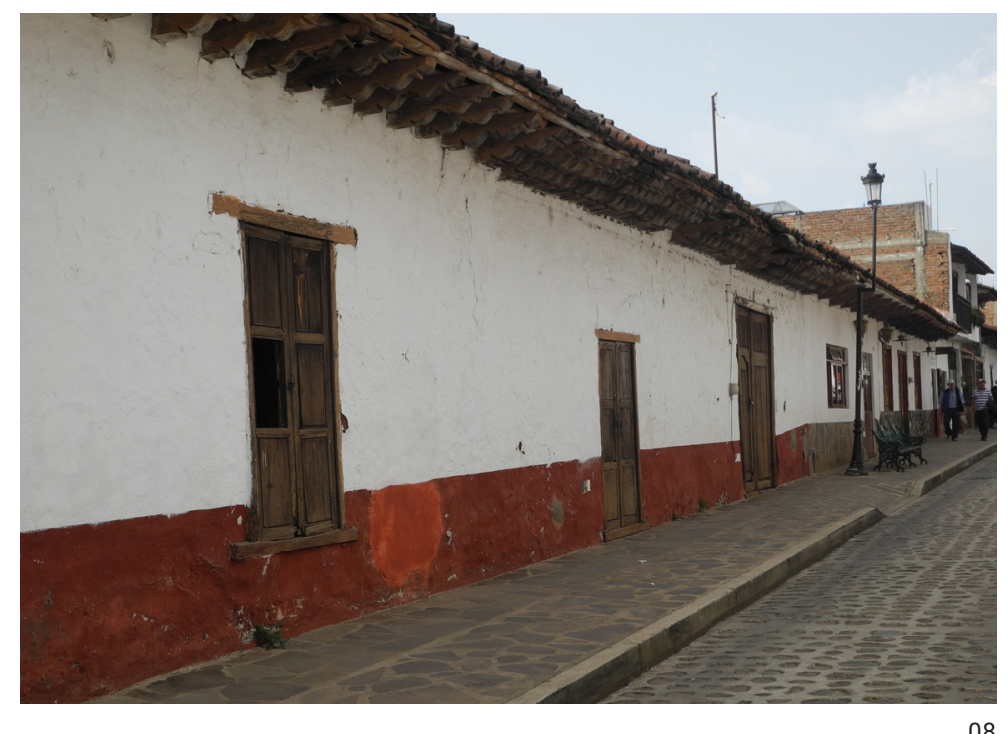

08

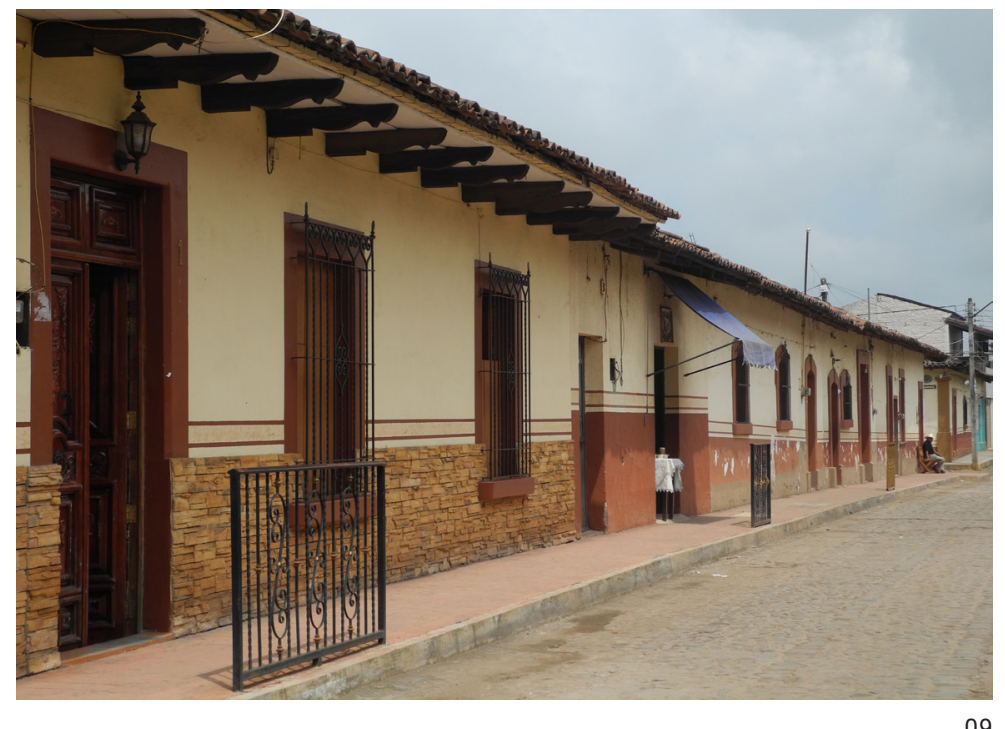

07. Pueblo Michoacán, s/data

08. Mazamitla, Jalisco, 2017

09. Concepción de Buenos Aires, Jalisco, 2017

10. Mazamitla, Jalisco, 2017

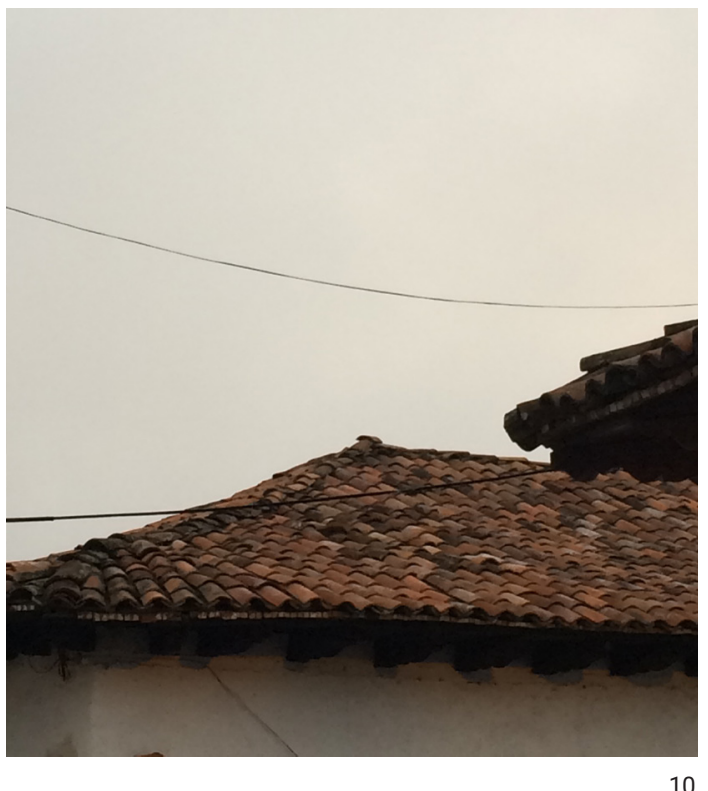




\subsection{As paisagens da infância}

Nascido em Guadalajara em 1902, no estado de Jalisco, na casa dos pais: Juan José Barragán e Angela Morfín de Barragán, localizada na rua Pedro Loza, 168. Terceiro entre 9 irmãos. Em sua infância Luis Barragán, passou tempo entre escolas católicas e largas temporadas na fazenda Corrales da família, localizada à poucos quilômetros de distância do pequeno povoado El Volantín, na zona da Sierra del Tigre à sudeste de Guadalajara, e próxima ao lago de Chapala. As montanhas da Sierra del Tigre, com sua topografia entre 2100 à 2800 metros acima do nível do mar, conformam o ponto mais alto do estado de Jalisco. Sobre esta zona montanhosa coberta por bosques e terra colorida (o solo é composto por tepetate, charanda e topure, três tipos de terra que dão variedade nas cores). A vegetação predominante descrita no site da Secretaria de Cultura do Estado de Jalisco e com nomenclatura local são pino, encino, roble, madroño, fresno, pinabeto, oyamel, huizache, palo dulce, granjeno, acebuche, izote, colorín, tejocote, pinguica, zarzamora, maguey pulquero e nopal. Resultando em uma paisagem montanhosa com pinheiros, carvalhos, magueis e cactos. 0 clima é semiseco, e a temperatura média é 17 graus centígrados. Sobre o maciço montanhoso se encontram alguns povoados com traçado regular em quadrículas com uma praça principal ao centro, entre eles: Mazamitla, Manzanilla de la Paz e Concepción de Buenos Aires. Ainda hoje permanecem nestes povoados as ruas de pedras, casas de adobe com estrutura de madeira e cobertura com telhas de barro ${ }^{5}$. Esses povoados se mantiveram isolados até a década de 1960 quando foi executada uma estrada de ligação entre Mazamitla e a estrada federal Morelia. Até então a comunicação à Guadalajara era feita por cavalos (para descer as serras), de barco (para cruzar o lago de Chapala) e de trem (até Guadalajara). Essa vivência com a vida local deixou a Barragán:

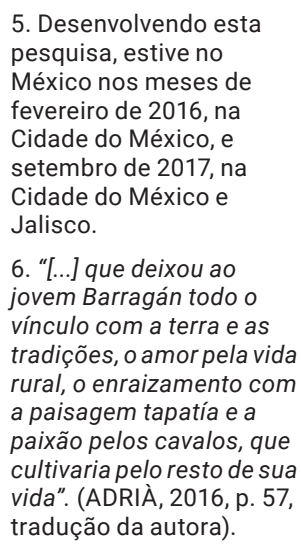

6. "[...] que deixou ao jovem Barragán todo o vínculo com a terra e as tradições, o amorpela vida rural, o enraizamento com a paisagem tapatía e a paixão pelos cavalos, que cultivaria pelo resto de sua vida". (ADRIÀ, 2016, p. 57, tradução da autora)

[...] dejó en el joven Barragán todo el vínculo con la tierra y las tradiciones, el amor por la vida rural, el enraizamiento con el paisaje tapatío y la pasión por los caballos, que cultivaría el resto de su vida. (ADRIÀ, 2016, p. 57)
O que permanece hoje da fazenda Corrales são ruínas de adobe, cercas, um tanque de água retangular - bebedouro para cavalos - e um volume edificado na cor branca onde ainda se encontram o telhado com estrutura de madeira e telhas de barro e um pequeno vestíbulo de acesso à casa. Neste espaço avarandado está construída uma escada que recebia adornos e objetos. Esse volume escalonado aparece em diversos momentos na obra de Barragán.

Na década de 1940 o governo de Jalisco construiu uma barragem no rio Pasión, conformando uma represa e inundando os currais da fazenda Corrales. Esses espaços que separavam os animais, construídos com muros de pedra, se encontram submersos e o que permanece hoje na paisagem são vestígios desses muros, linhas de pedras desenhadas na superfície da água. 

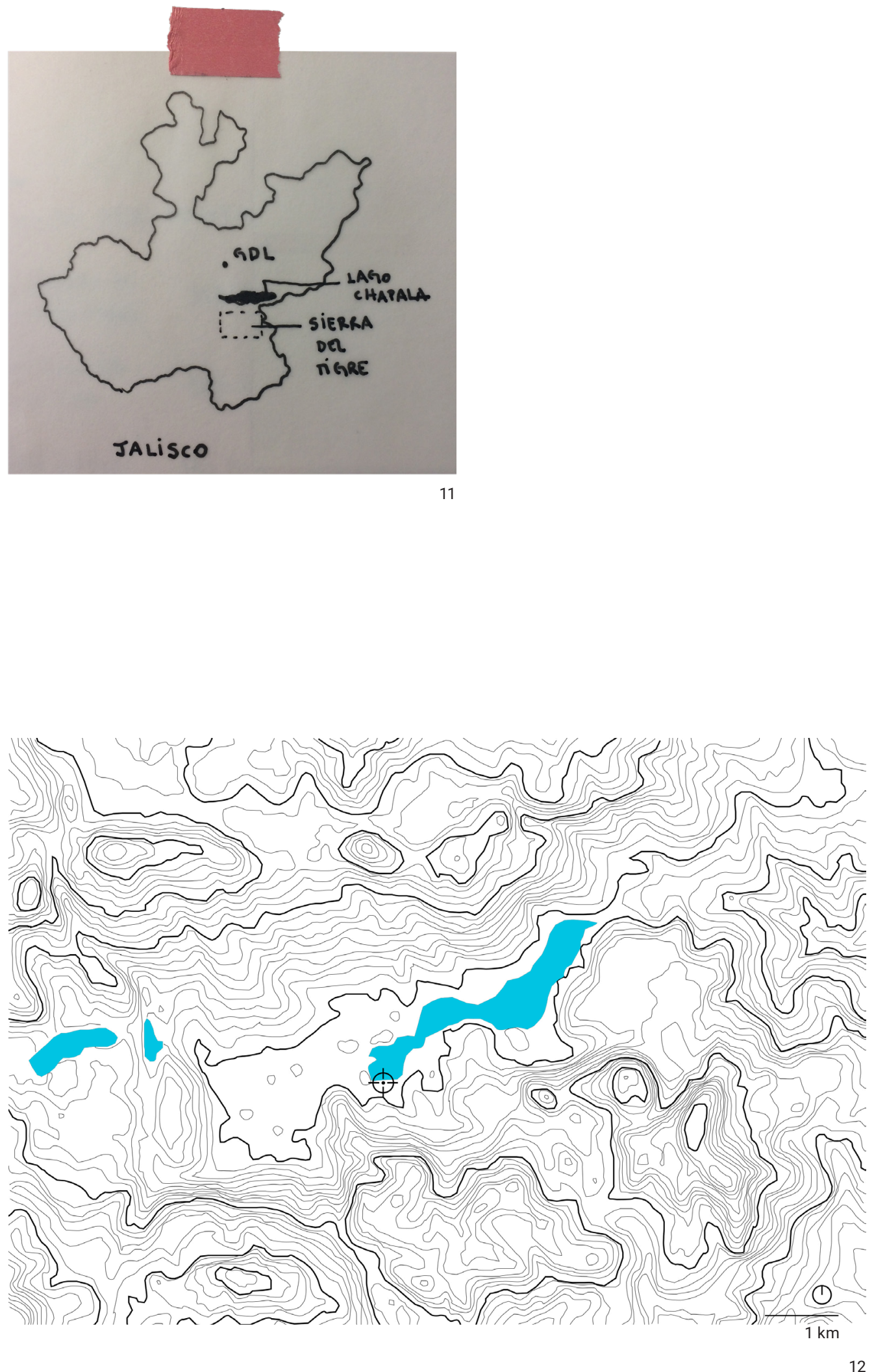


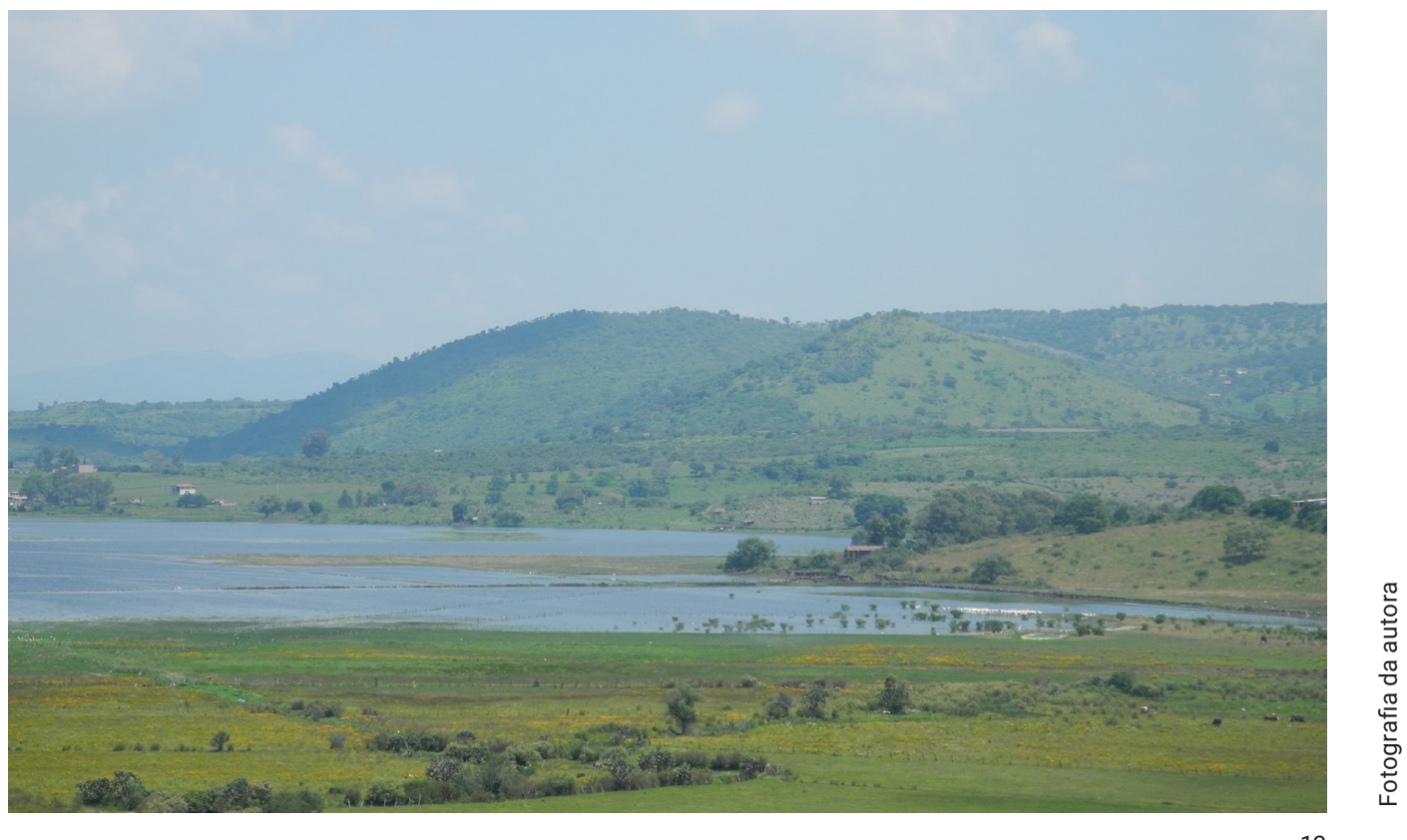



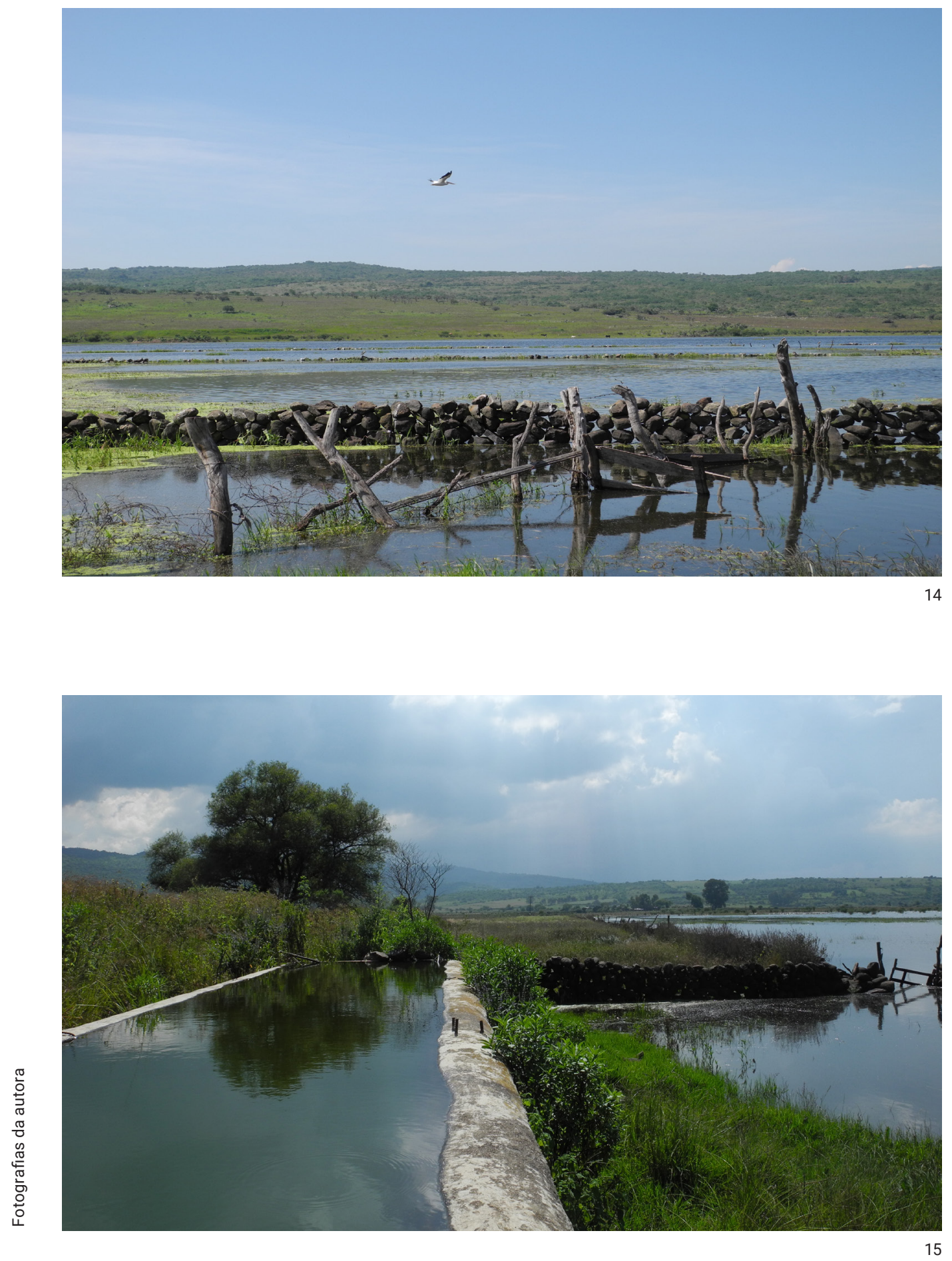


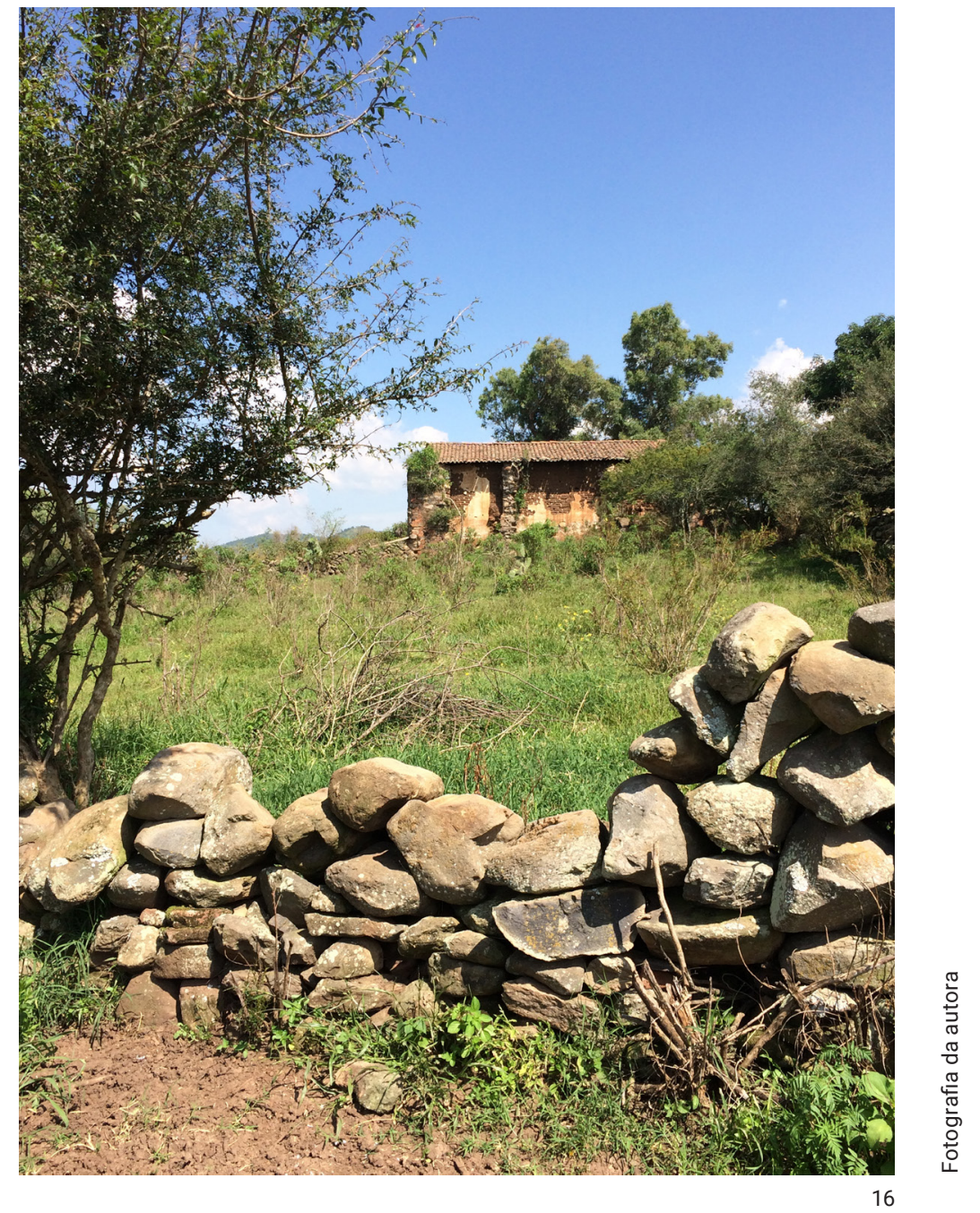




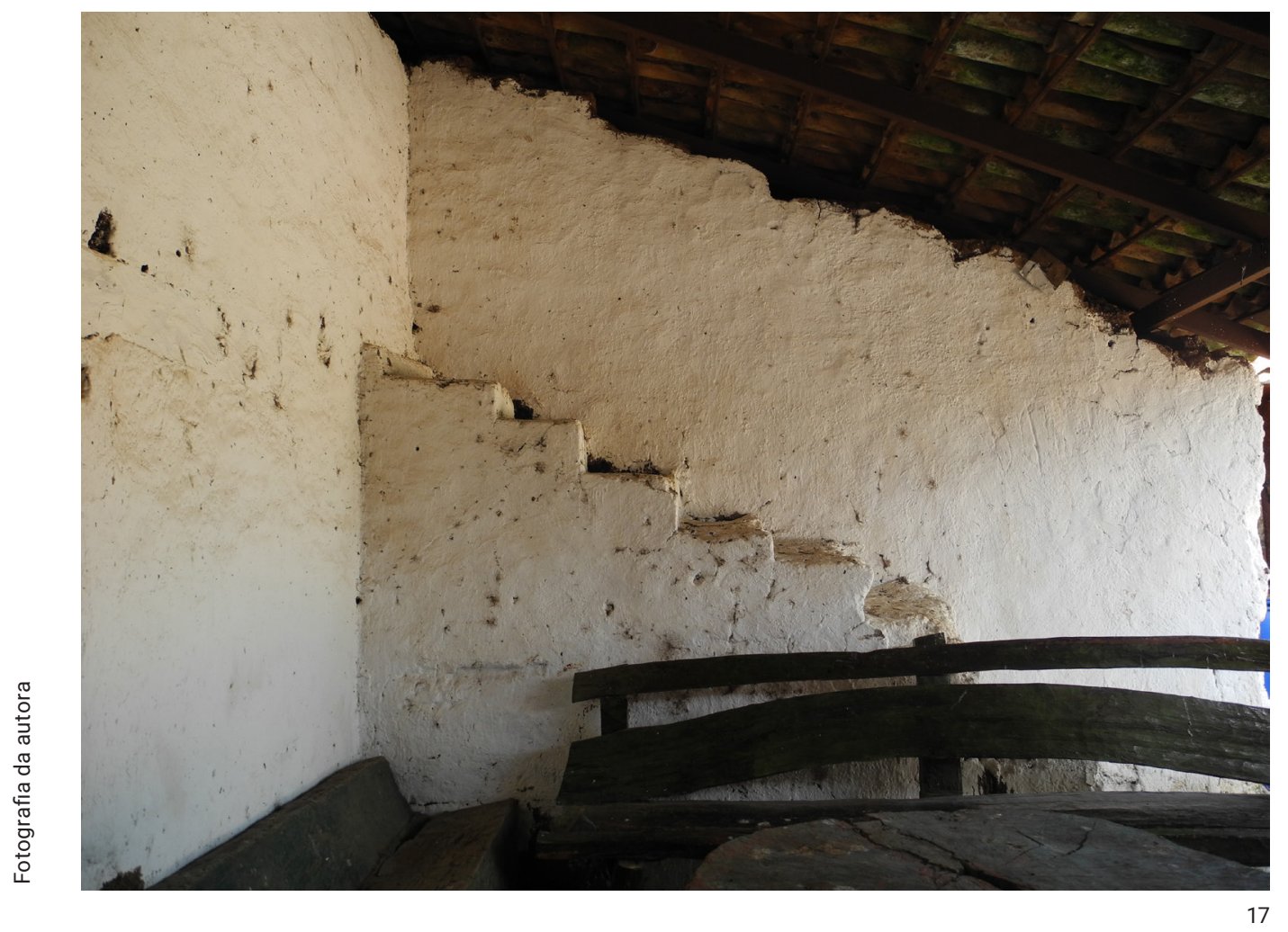



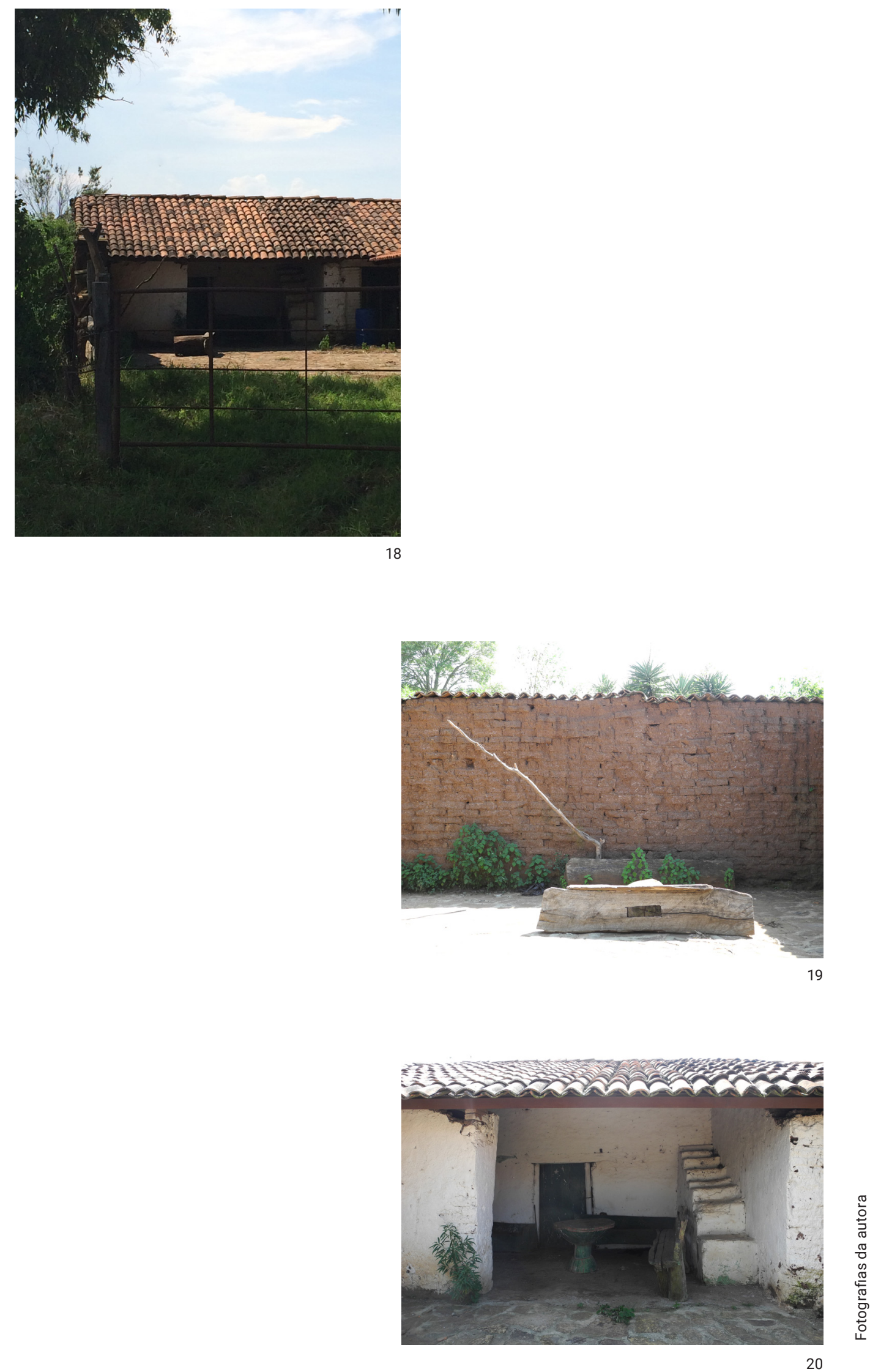


\subsection{Contextos histórico e cultural e os anos de formação}

Quando Luis Barragán nasceu, o México passava pelo regime político de Porfírio Díaz (1830-1915) que durou por mais de três décadas entre dois momentos: 1877 a 1880 e 1884 a 1911. Este período ficou marcado por uma estabilidade política e crescimento econômico. 0 discurso político de Porfírio Díaz promovia a modernização do país, que se fez através do desenvolvimento de infraestruturas com investimentos estrangeiros, através da expansão de estradas, de linhas ferroviárias e de portos. A cultura oficial promovia uma aristocracia mexicana, com a pintura e a arquitetura a serviço da ideologia do Estado (ANDA, 1995, p. 149). Arquitetos de fora do país foram contratados pelo governo para projetarem diversos edifícios de caráter público resultando em um ecletismo arquitetônico. As estruturas de ferro chegavam de navio e de certo modo, as técnicas construtivas europeias foram incorporadas na construção desses edifícios resultando em arquiteturas sob moldes europeus. Foram trazidos também materiais como mármores, granitos, bronze e vidro (ANDA, 1995, p. 150). Edifícios icônicos na Cidade do México como o Palácio de Comunicações (atualmente Museu Nacional de Arte) de 1908; o Palácio dos Correios de 1902-07 e o Teatro Nacional (Palácio de Belas Artes) de 1904-347 foram projetados por arquitetos italianos. 0 primeiro por Silvio Contri e o outros, ambos projetados por Adamo Boari. Eram profissionais liberais a serviço do Estado responsáveis pela produção de edifícios emblemáticos da cidade. Este período ficou conhecido como a "paz porfiriana", na qual o investimento de capital estrangeiro encontra espaço para a construção.

Guadalajara naquele momento apresentava na paisagem urbana, além das construções coloniais de adobe e pátios internos, este novo modelo de cidade aos moldes franceses com características remanescentes do porfiriato: traçado urbano em diagonais, praças, monumentos, armazéns e casas neoclássicas, evidenciando traços de uma arquitetura eclética. Desde 1888 conectada pela linha férrea com a Cidade do México, uma cidade provinciana em crescimento.

Este período reconhecido pelo início da modernização do país, com padrões europeus apropriados tanto na educação como na própria conformação das novas cidades, culminou em um movimento social em 1910 que questionava os aspectos da estrutura social no país: a divisão das terras, as relações de produção e a distribuição de benefícios econômicos, a defesa da riqueza natural do país e da educação nacional (ANDA, 1995, p.150). Francisco Madero (1873-1913) lança uma campanha oficial contra a reeleição de Porfírio Díaz e se promove como candidato à presidência. De modo a minimizar as distâncias sociais existentes e, em uma busca de resgate e defesa dos valores culturais mexicanos, inicia o período da Revolução marcado por um enorme período de instabilidade política e confrontos entre os revolucionários. Emiliano Zapata (1879-1919) escreve o Plano de Alaya em 1911 junto com o professor Otílio Montaño (1877-1917) pela luta da reforma agrária no sul do país, de modo à restituir as terras dos povoados retiradas por Porfírio Díaz, e redistribuir parte das terras das grandes fazendas à população local. Ao norte do país, Pancho Villa (1878-1923) liderava o exército División del Norte. Venustiano Carranza (1859-1920) toma a presidência em 1915 e conforma a Constituição Liberal em 1917 a partir de demandas sociais como a reforma agrária, por exemplo. A busca da tradição local culmina com o neocolonial

7. A construção foi interrompida no caída do porfiriato e terminada em 1934 pelo arquiteto Federico Mariscal (1881-1971). O edifício simbólico da ditadura, foi retomado durante a Revolução, que não só resgatou o edifício como o nomeou de "Palácio" agregando usos culturais ao edifício. (ANDA, 1995, p. 162) 
como movimento arquitetônico daquele período (ANDA, 1995, p. 164). 0 arquiteto Federico Mariscal (1881-1971) é um dos principais representantes desse movimento neste período, e sua obra reflete a relação entre identidade nacional e patrimônio histórico. Segundo Enrique X. de Anda, arquiteto, professor e pesquisador na Faculdade de Arquitetura e de Filosofia e Letras da UNAM, o neocolonial foi determinante porque era a imagem mais próxima aos valores estéticos do nacionalismo.

As influências artísticas neoclássicas europeias começam a ser altamente questionadas e artistas deixam de pintar em pequenos formatos passando a expressar à coletividade a imagem da história do país através do muralismo. Estes murais com enormes formatos representam uma estética local conformando uma nova narrativa da história do México e celebrando o processo revolucionário através de novas técnicas e novos suportes, evocando um caráter monumental. Fica marcada, neste período, a busca de uma identidade cultural com uma carga simbólica bastante significativa, representando o povo mexicano como um todo e incluindo povos indígenas, entre eles os náhuatles, mayas, zapotecas, mixtecas, huastecas, huicholes, lacandones, entre outros, antes esquecidos nas representações do século XIX. Essa ruptura retoma o passado pré-colombiano aplicando novos conceitos de beleza no popular e na vida cotidiana (EDER, 1990, p. 102). Ainda que com ideologias distintas entre si, Diego Rivera (1886-1957), David Alfaro Siqueiros (1896-1974) e José Clemente Orozco (1883-1949) apropriam-se das técnicas do muralismo para pronunciar seus ideais e imaginários tomando como base o espírito nacionalista.

Foi a época na qual, sob o governo de Álvaro Obregón (1920-1924) foi criada a Secretaria de Educação, sob coordenação de José Vasconcelos (1882-1959), fomentando o desenvolvimento de programas educacionais em uma escala nacional, incluindo a difusão da cultura na alfabetização e nas atividades artísticas populares (ANDA, 1994, p. 168). 0 muralismo foi então uma estratégia de educação através das imagens, levando ao povo os ideais revolucionários e acontecimentos históricos. José Vasconcelos assume o cargo de Secretário de Educação incluindo a cultura em suas demandas, e não apenas constrói inúmeras escolas, como reformula todo o processo didático no país, assumindo a mestiçagem na formação no povo mexicano, tema de seu livro La Raza Cósmica (1925).

Neste contexto, Luis Barragán entra na Escola Livre de Engenharia de Guadalajara em 1919 (fundada em 1901 pelo engenheiro licenciado Don Ambrosio Ulloa), que oferecia também aos estudantes a possibilidade de obtenção de título de engenheiro e arquiteto através de cursos extras de Composição e História da Arte e, e da elaboração de um trabalho específico ao final do curso (GORTÁZAR, 1975, p. 12). Barragán obtém o título de engenheiro civil especializado em obras hidráulicas em 1923 e inicia os estudos para a obtenção do título de arquiteto sob orientação de Agustín Basave.

Em uma entrevista para Alejandro Ramírez Ugarte em 1962, ao falar sobre a sua formação e do trabalho com seu irmão engenheiro Juan José, Barragán afirma: 
Agustín Basave fue un hombre que despertó mucha inquietud entre los estudiantes, inquietud por las artes en general

[...] Pudiera decir que Agustín fue el que despertó muchas vocaciones y así fue que yo empecé a interesarme por la parte artística, para la cual no teníamos ninguna preparación; yo tomé el gusto por todo eso al haber trabajado en hacer proyectos de casas y otras construcciones con mi hermano. (BARRAGÁN, 1962, p. 72 e 73$)^{8}$

Entre 1924 e 1925 Barragán visita pela primeira vez a Europa acompanhado de seu professor Agustín Basave, e em seu retorno ao México, a Escola de Arquitetura já não existia mais, não conseguindo obter seu título de arquiteto. Essa viagem redimensionará a sua relação com a paisagem.
8. "Agustín Basave foi uma homem que despertou muita inquietude entre os estudantes, inquietude pelas artes no geral [...] Poderia dizer que Agustín foi o que despertou muitas vocações e assim foi que comecei a me interessar pela parte artística, a qual não tínhamos nenhuma preparação; eu comecei a me interessar por tudo isso por ter trabalhado com projetos de casas e outras construções com meu irmão". (BARRAGÁN 1962 , p. 72 e 73, tradução da autora). 


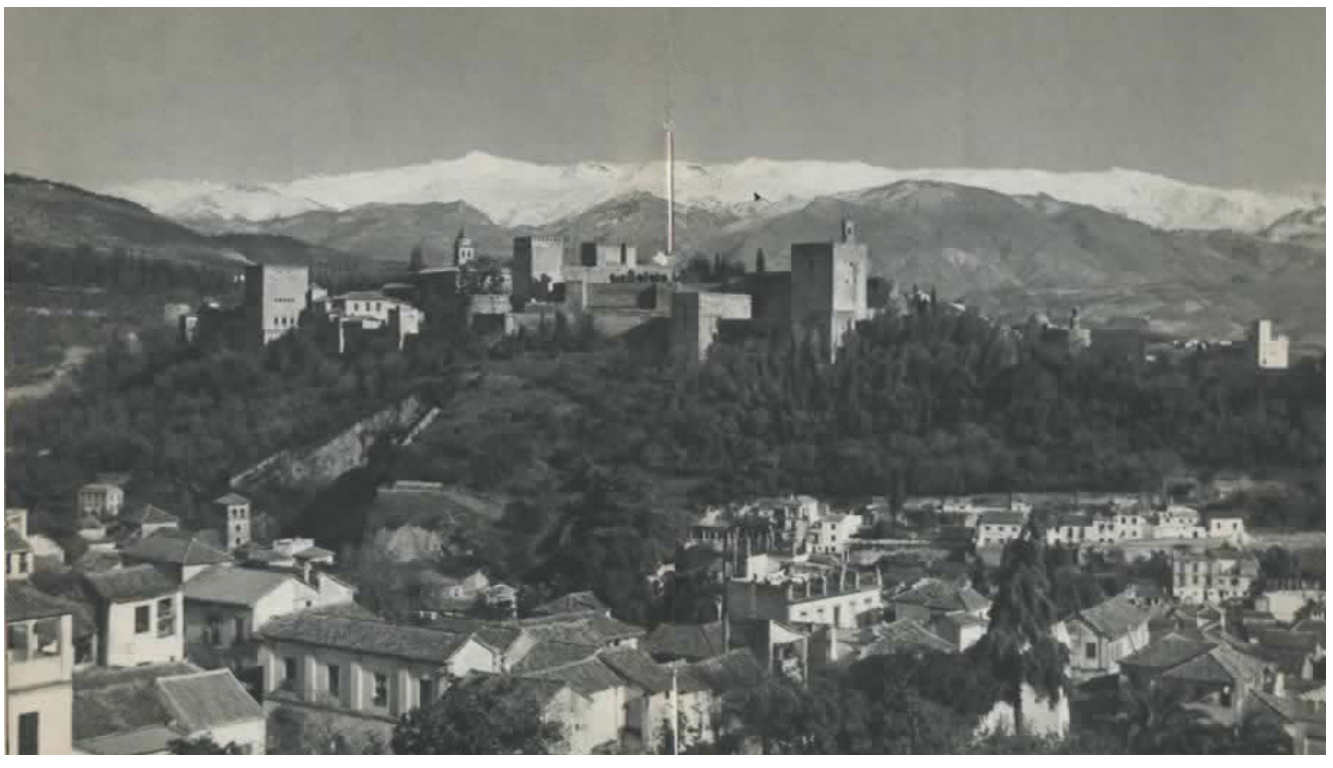

\subsection{Primeiro encontro com a Europa}

Fue en ese viaje que hice por Europa inclusive, un viaje en el cual aprendí francés, y visité exposiciones, aunque no me ocupé especialmente - o absolutamente nada - en la arquitectura. Fue una visión general de la historia del arte a través de sus principales naciones, viendo las que llamaban "ciudades de arte" en Europa. (BARRAGÁN, 1962, p. 73) ${ }^{9}$

Entre 1924 e 1925, Barragán realiza seu primeiro encontro com a Europa saindo do México pelo porto de Veracruz. Conhece a França, a Espanha, a Itália e a Grécia. Ainda afirmando que não foi uma viagem especificamente de estudos, é neste momento que Barragán toma contato pela primeira vez com a arquitetura moderna europeia; com os jardins, ilustrações e contos de Ferdinand Bac (1859-1952); e com os pátios sombreados, jardins e espelhos d'água de Alhambra. Tais lugares são relembrados por ele ao falar de suas memórias, da importância de ver e de suas experiências que se refletem também na sua produção arquitetônica. Passou um ano e meio na Europa conhecendo lugares, visitando exposições e investindo em sua biblioteca pessoal. Escreve uma carta aos seus pais desde Paris, em 1924, e diz o seguinte: "Sigo conociendo lugares que me parecen muy bonitos. Estoy haciendo dibujos para luego enseñárselos y Dr. Zuloaga ha tomado muchas fotografías. También compro postales de todo lo que voy viendo" (BARRAGÁN, 1924, p. 139)10. A cada viagem Barragán selecionava e guardava postais, e até hoje se mantêm guardados na Fundação Barragán na Cidade do México.

O contato de Luis Barragán com a arquitetura moderna se deu ao visitar a Exposição de Artes Decorativas em Paris (Exposition Internationale des Arts Decoratifs et Industrials Modernes) em 1925. Apesar do caráter temporário, foram apresentados na exposição alguns pavilhões que se contrapunham com a arquitetura neoclássica vigente, oferecendo uma primeira tentativa de síntese de posições contrárias

9. "Foi nesta viagem que fiz pela Europa inclusive uma viagem na qual aprendi a língua francesa, e visitei exposições, não me preocupando especialmente - ou absolutamente

nada - pela arquitetura. Foi uma visão geral da história da arte através de suas principais nações, visitando como as chamavam 'cidades de arte' da Europa". (BARRAGÁN, 1962, p. 73, tradução da autora).

10. "Sigo conhecendo lugares que me parecem muito bonitos. Estou fazendo desenhos para logo mostrá-los e o Dr. Zuloaga tem tirado muitas fotos. Também compro postais de tudo o que vou vendo" (BARRAGÁN, 1924, p. 139, tradução da autora). 
(GARAY, 2004, p. 10 e 11). É a partir desta exposição que anos mais tarde surge o termo Arte Déco. A maioria dos pavilhões mantinham o caráter neoclássico, mas apareceram dois pavilhões com ideais vanguardistas (cubista, futurista e construtivista): o pavilhão "L’Sprit Nouveau" de Le Corbusier (1887-1965), e o pavilhão soviético de Konstantin Melnikov (1890-1974), contrapondo à esses ideais neoclássicos e com resistência às artes decorativas. 0 austríaco Frederick Kiesler (1890-1965) apresentou a exposição “Cité dans L'Espace”, também com expressão vanguardista. De todo o conjunto apresentado na Exposição, são essas as arquiteturas que impressionaram Barragán.

Nesta mesma Exposição, o paisagista francês, e também ilustrador e escritor, Ferdinand Bac (1859-1952), também apresentou alguns jardins. Luis Barragán visita esses jardins e toma contato com suas publicações ${ }^{11}$, despertando seu interesse por jardins e pelo desenho de paisagem. As ilustrações e textos de Bac tiveram forte impacto no jovem mexicano recém chegado ao velho continente e induziram sua vivência ao passar pelos jardins das vilas italianas, pelas paisagens de Andalucia, pelos pátios, pelos espelhos d'água e pelos jardins de Alhambra e de Generalife em Granada (ZANCO, 2002, p. 46). Barragán escreve um texto alguns anos depois dizendo "hay que buscar que las casas sean jardines, y los jardines sean casas" (BARRAGÁN, 1931, p. 15) ${ }^{12}$.

Nesta mesma viagem Barragán visita Alhambra. Fica deslumbrado com a fortaleza vermelha, seus caminhos, jardins e fontes. Elena Poniatowska, em uma entrevista com Barragán, pergunta porque ele fazia portas tão pequenas, seguidas de um corredor e que abruptamente se abriam em um recinto com tetos e muros altos. Barragán responde comentando a sua experiência no pátio Arrayanes:

Para visitar el patio de los Arrayanes en Alhambra, camina uno por un túnel muy pequeño - yo ni siquiera podía enderezarme - y en un momento dado, independientemente del olor de los arrayanes y del mirtos que llegaba a través del túnel, se me abrió el espacio maravilloso de los pórticos muy contrastados de ese patio contra los muros ciegos y el ruido del agua. Esa emoción no se me ha olvidado jamás. (BARRAGÁN, 1976, p. 115)13

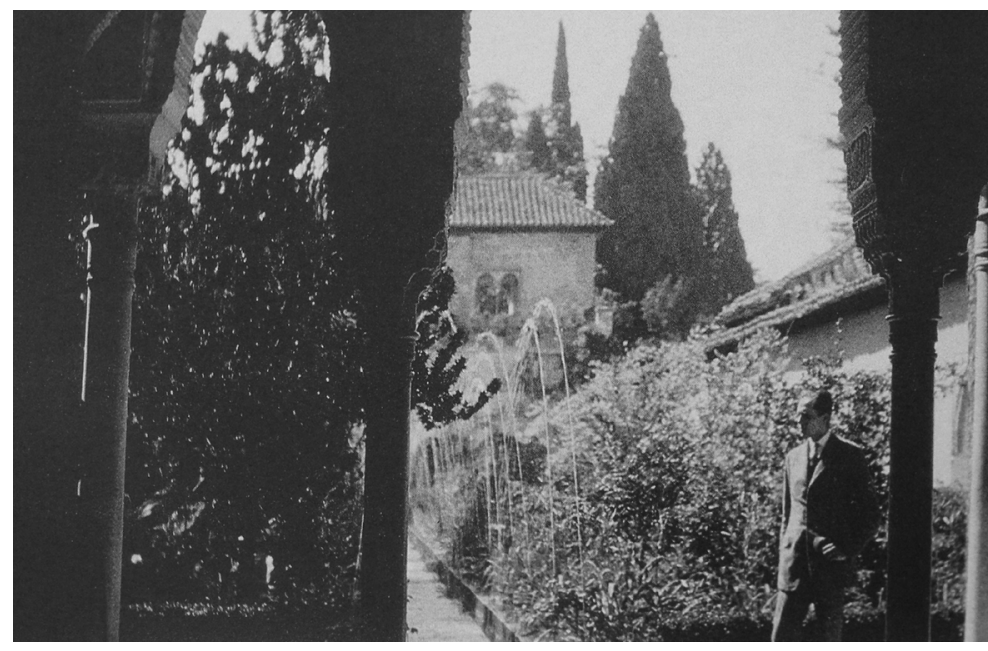


Localizada na cidade de Granada na Espanha, Alhambra salta os olhos sobre a colina La Sabika. Palácios muçulmanos e estruturas cristãs do século XVI. Recintos com plantas retangulares que se abrem para pátios. Passagens sombreadas, arcadas colunadas, fontes de água e tanques, e um sistema de irrigação composto por canais. Com ricos detalhes em arabesco e azulejos pintados, a arte islâmica em máxima potência. Azul, vermelho, amarelo e dourado. Os jardins ganham presença e fazem parte do todo. A água no pátio Arrayanes vira espelho, refletindo sua arquitetura. Alhambra surpreende também pelas suas vistas. Do alto da colina é possível avistar as mais variadas paisagens, picos nevados e uma vegetação tropical (ANTEQUERA, 1961, p. 14). Luis Barragán reconhece a relação com a paisagem, a relação entre os espaços internos com áreas externas, a presença constante da água através das fontes e espelhos d'água e utiliza essas relações posteriormente em sua própria produção.

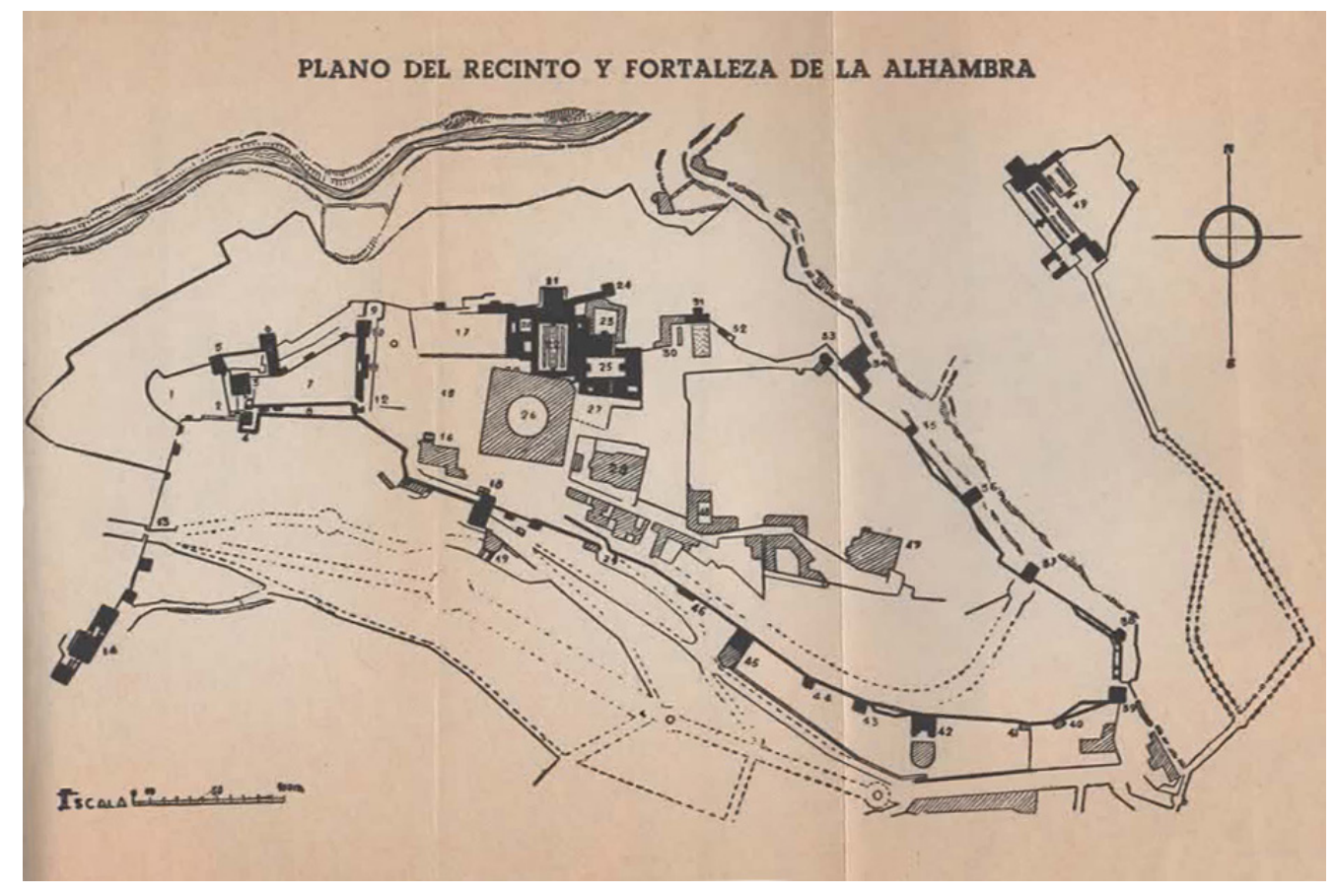




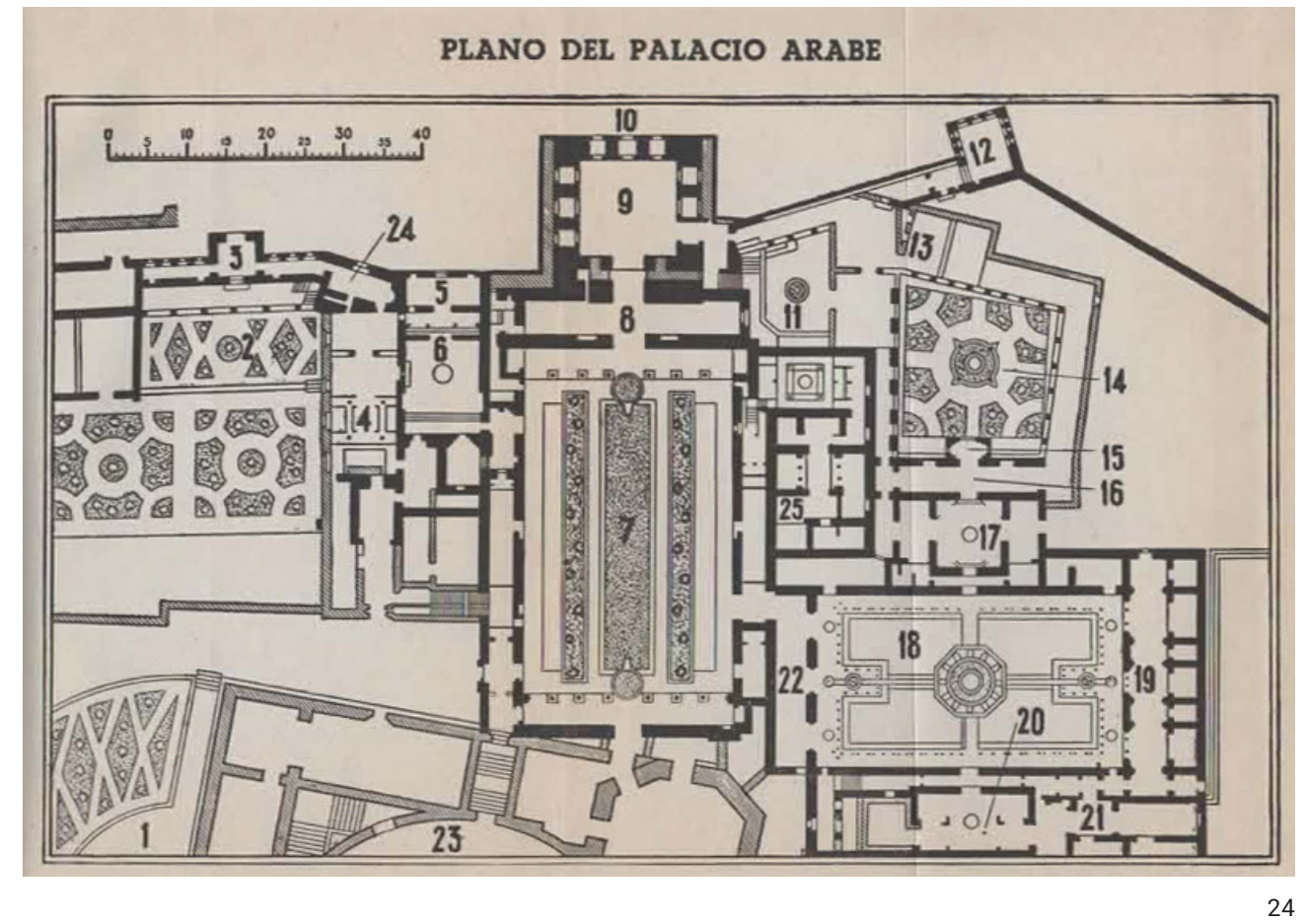




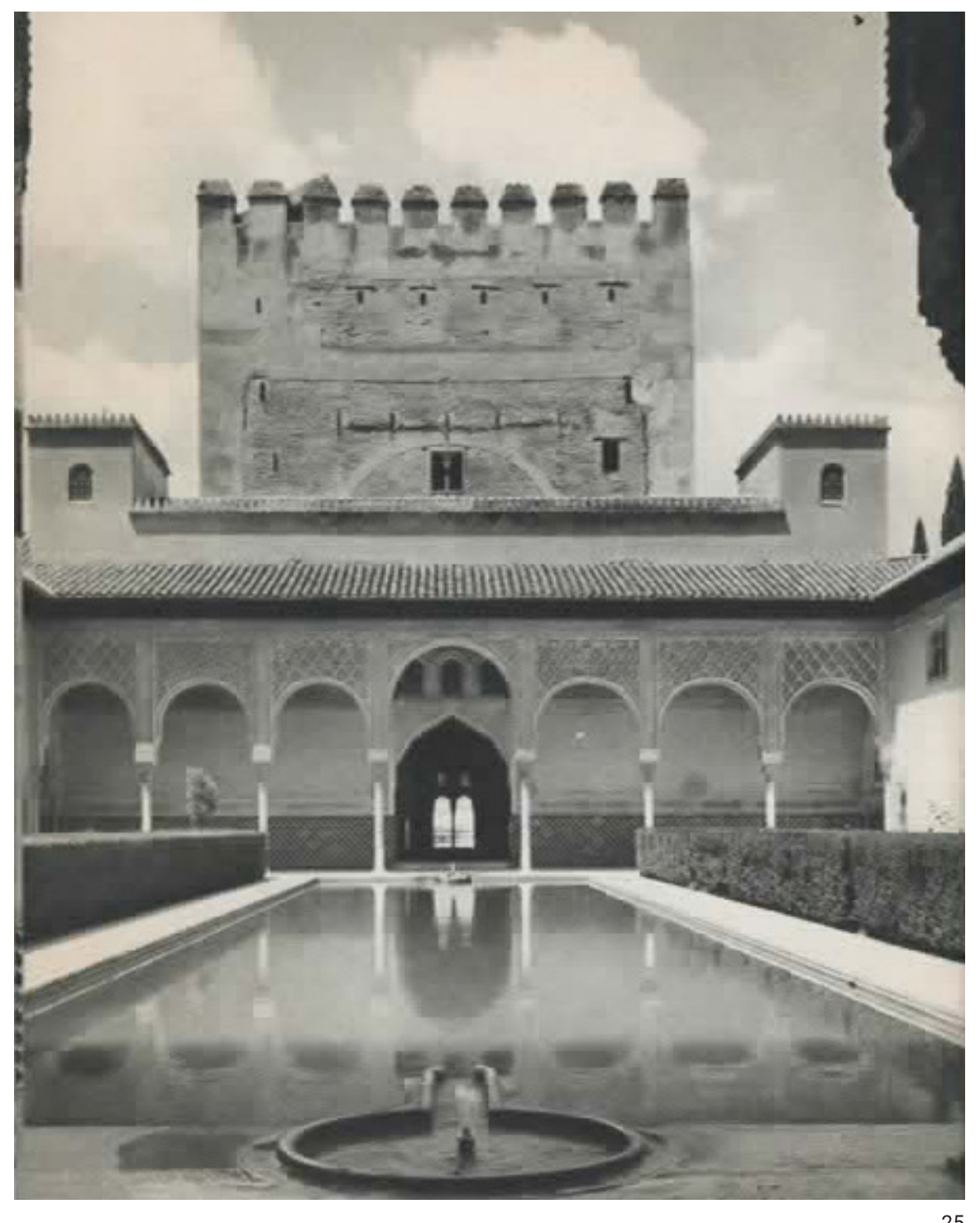

25 

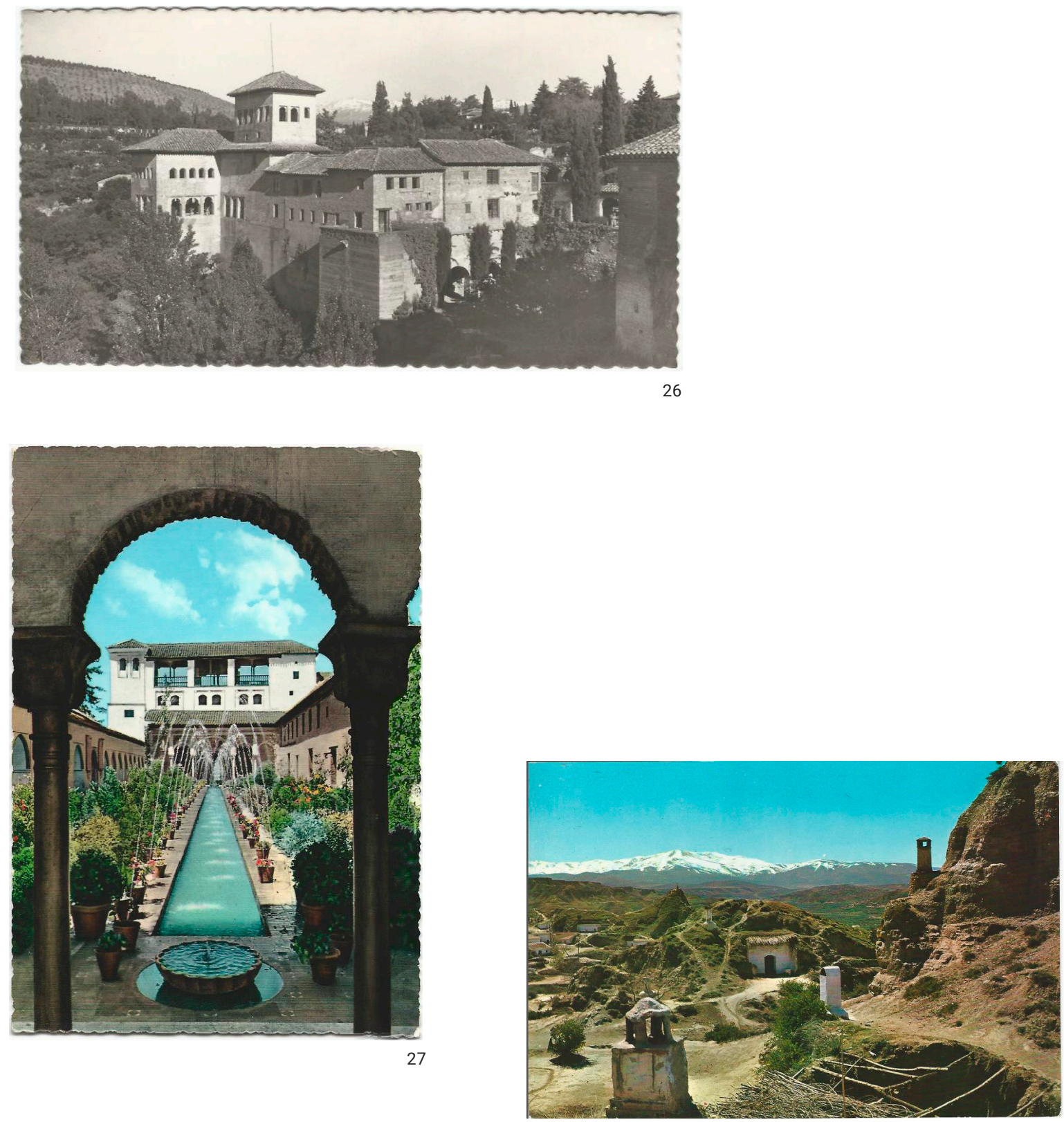

28
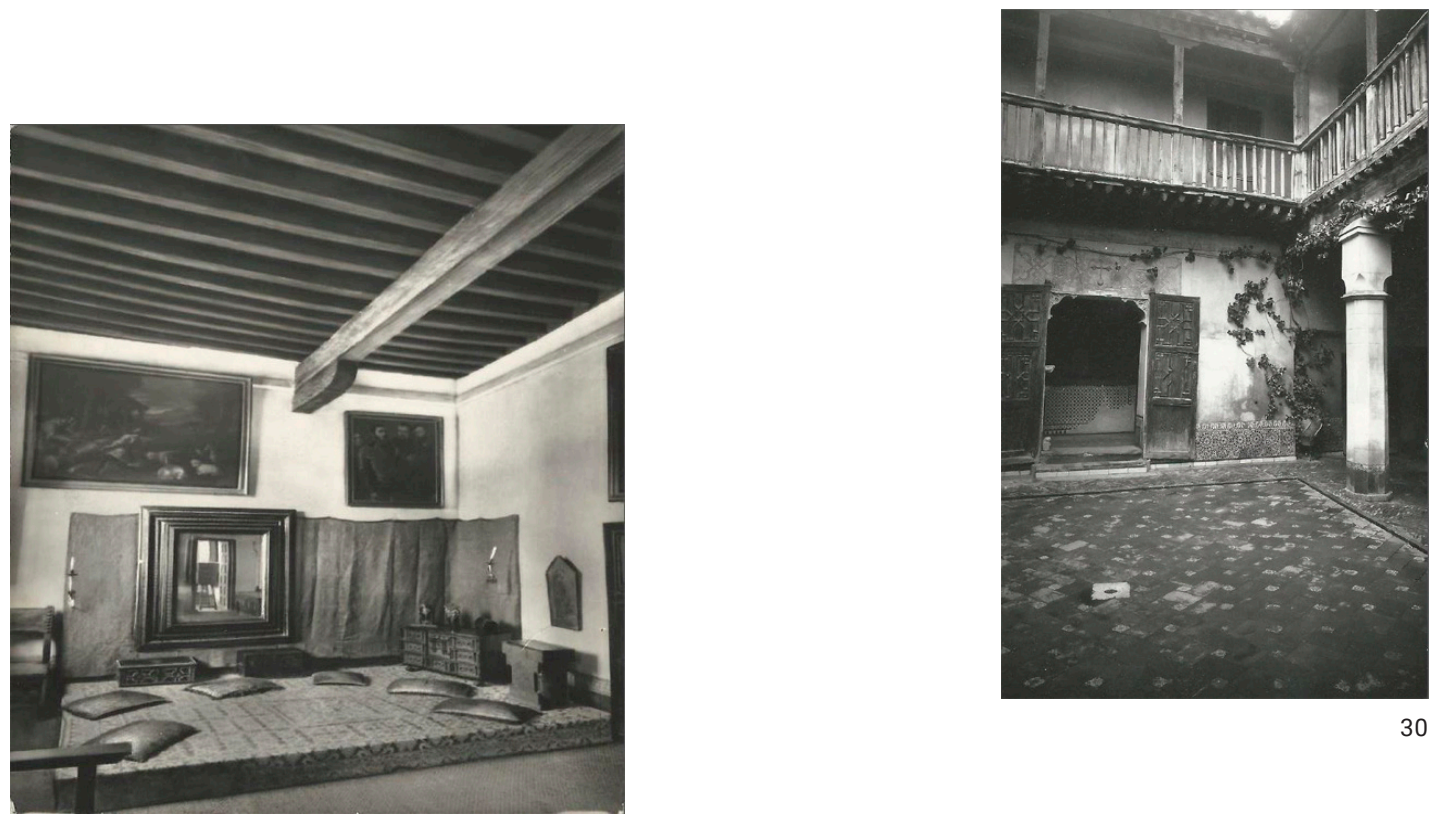
Los tejados de color, las fuentes y las macetas con flores son elementos que alegran y dan vida. Yo he empleado cuidadosamente esos elementos con la ambición de que las casas sonrían aun bajo la lluvia. (BARRAGÁN, 1931, p. 16) ${ }^{14}$

Após seu retorno ao México, Barragán trabalha como engenheiro hidráulico junto com seu irmão Juan José, para a Zona de irrigação do lago de Chapala, Jalisco (região próxima ao rancho da família e cidade em que a família também passava verões) e inicia seus primeiros projetos de casas unifamiliares em Guadalajara (Casa Robles León, 1927-1928; Casas Robles Castillo, 1927; Casa González Luna, 1928-29; Casa Cristo, 1929; entre outras). A historiografia da arquitetura moderna no México define a produção arquitetônica de Luis Barragán em três fases (Aníbal Figueroa Castrejón, Enrique de X. Anda, Louise Noelle, entre outros).

Sob esse aspecto, nessa primeira fase de Barragán, entre 1927-1935, seus projetos respondem às demandas dos clientes incorporando elementos arquitetônicos tradicionais e a relação entre os espaços internos com as áreas externas. Trata-se de um conjunto residências para clientes particulares. Algumas dessas casas localizam-se no centro histórico consolidado de Guadalajara, e a maioria em novos bairros que surgiam naquele momento, como o bairro Americana. Apesar das marcas do tempo, essas casas resultam em verdadeiras joias entre a malha urbana de Guadalajara. Barragán começa a trabalhar já neste momento o desenho dos espaços externos, dos pisos, dos pátios, e como ele mesmo diz, "arquitetura exterior", na busca de uma linguagem própria (PALOMAR, 1994, p. 22). A revista Artes de México publicou uma edição completa sobre a obra de Luis Barragán e Octavio Paz abre a revista um artigo dizendo que Barragán era moderno, mas não modernista, pois segundo ele, para sermos modernos de verdade, precisamos antes nos reconciliar com nossa tradição:

En la arquitectura popular mexicana se funde la tradición india precolombiana con la tradición mediterránea. Las formas son cúbicas, los materiales son los que se encuentran en la localidad y los muros están pintados con vivos colores - rojos, ocres, azules - a diferencia de los pueblos mediterráneos que son blancos. (PAZ, 1994, p. 17) ${ }^{15}$

Barragán reconhece a beleza da arquitetura dos povoados mexicanos e incorpora os elementos da cultura popular. Inclui em sua arquitetura arcos, pátios, fontes, pérgolas. Atento à passagem da vida pública para a vida íntima, aparecem caminhos, jardins e vestíbulos nas entradas das casas. Explora o uso de terraços jardins com coberturas planas. Já nessa primeira fase inicia experimentos com jogo de luz nos ambientes internos através da entrada de luz natural por claraboias, através de vidros pintados e de elementos vazados de madeira. Estes elementos filtram a luz natural promovendo uma luz difusa dentro dos ambientes. Esse imaginário é flagrado também nas ilustrações de Ferdinand Bac.

Na Casa González Luna (1928-29) por exemplo, a pérgola de concreto da cobertura, tem o mesmo desenho das estruturas de madeira dos beirais das casas de 
Mazamitla. As portas de madeira são exatamente como as portas de madeiras dos povoados mexicanos de Jalisco e Michoacán. Lugares de memória.

Surge em Guadalajara, em 1929, uma revista quinzenal de cultura chamada Bandera de Pronvíncia e com ela diversas reuniões e debates entre intelectuais. Seus principais membros foram os escritores jalisienses Alfonso Gutiérrez Hermosillo, Agustín Yánez, Esteban A. Cueva, José G. Cardona Vera, Emmanuel Palacios e Efraín Gonzalez Luna. Abriram os encontros para diversos jovens, escritores e artistas, expandindo a discussão para além do estado de Jalisco. Contribuíram jovens de Veracruz, Sonora, Zacatecas e Colima. Luis Barragán, e seus amigos Ignácio Díaz Morales, e Rafael Urzúa participaram dessas discussões e contribuíram com textos e ensaios. 0 grupo denominado por eles "sem número e sem nome" se encontrava semanalmente para debaterem temas atuais relacionados principalmente a cultura e de uma certa forma como resistência aos modos da cultura impostas por Porfírio Díaz, e tendo como resposta a busca de uma realidade nacional. Alinharam-se enquanto pensamento a outro grupo de escritores "Los Contemporáneos", no qual Carlos Pellicer fazia parte, e que também produziam publicações relacionadas a arte e cultura mexicana da primeira metade do século XX. Bandera de Província tinha como manifesto a retomada da voz aos povoados, lugar onde para eles, vivia-se o essencial, o verdadeiro, longe do francês e do inglês (PALOMAR, 2014, p.22). De uma certa maneira essa articulação de fenômenos culturais conformariam a construção de identidades nacionais. Gerardo Murillo Cornado, conhecido como Dr. Atl (1875-1964), Jesús “Chucho" Reyes (1880-1977) e José Clemente Orozco (1883-1949) eram alguns dos representantes do movimento artístico em Jalisco e também em suas obras expressavam a busca de uma identidade nacional "verdadeiramente" mexicana.

As publicações de Ferdinand Bac que Barragán levou para o México por exemplo, Jardins enchantés e Les Colombières, ambas de 1925, serviram de forte influência inclusive para seus amigos, Ignacio Díaz Morales (1905-1992), Rafael Urzúa (19051991) e Pedro Castellanos (1902-1961), refletindo em suas arquiteturas. A produção arquitetônica dessa geração de arquitetos, Luis Barragán, Ignacio Díaz Morales, Rafael Urzúa e Pedro Castellanos, ficou conhecida como "Escuela Tapatía de Arquitectura" (CASTREJÓN, 1989, p. 72), que apesar de motivados pelas vanguardas europeias não conseguiam desprender-se totalmente da vertente neocolonial vigente neste momento em Guadalajara. Barragán encontra no desenho de jardins a liberdade para exercer a imaginacão, e comenta:

16. "[...] embruxar o lugar, embruxar os pátios, os cantos dos jardins e até ligar os jardins às casas, colocar um pouco de jardín dentro dos ambientes internos - esse movimento foi devido à Ferdinand Bac interpretado por Nacho Díaz, Rafael Urzúa e por mim". (BARRAGÁN 1962 , p. 80 , tradução da autora).

[...] el embrujar el lugar, el embrujar los pátios, los rincones de los jardines y hasta ligar los jardines con las casas, meter ya un poco el jardin en las habitaciones - ese movimiento fue debido a Ferdinand Bac, interpretado por Nacho Díaz, Rafael Urzúa y por mi. (BARRAGÁN, 1962, p. 80) ${ }^{16}$

Observar com atenção os jardins que Barragán olhava é relevante para a compreensão de sua obra. 

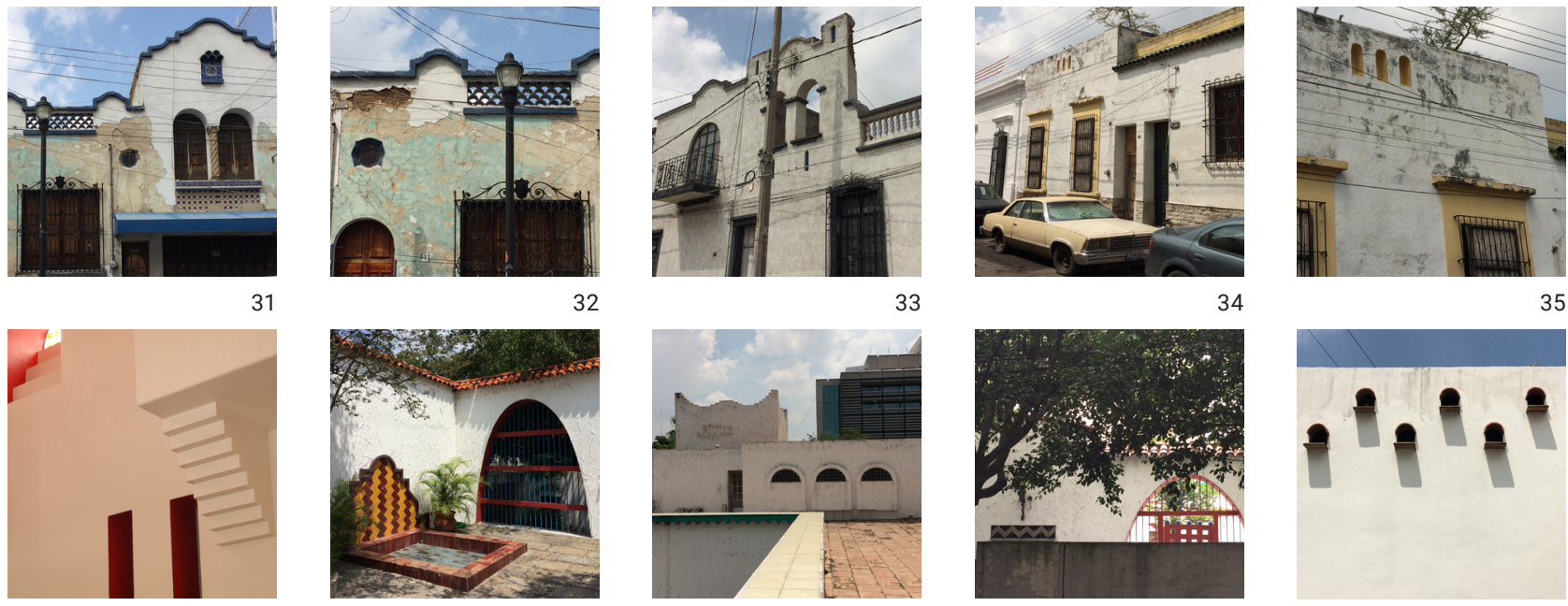

35
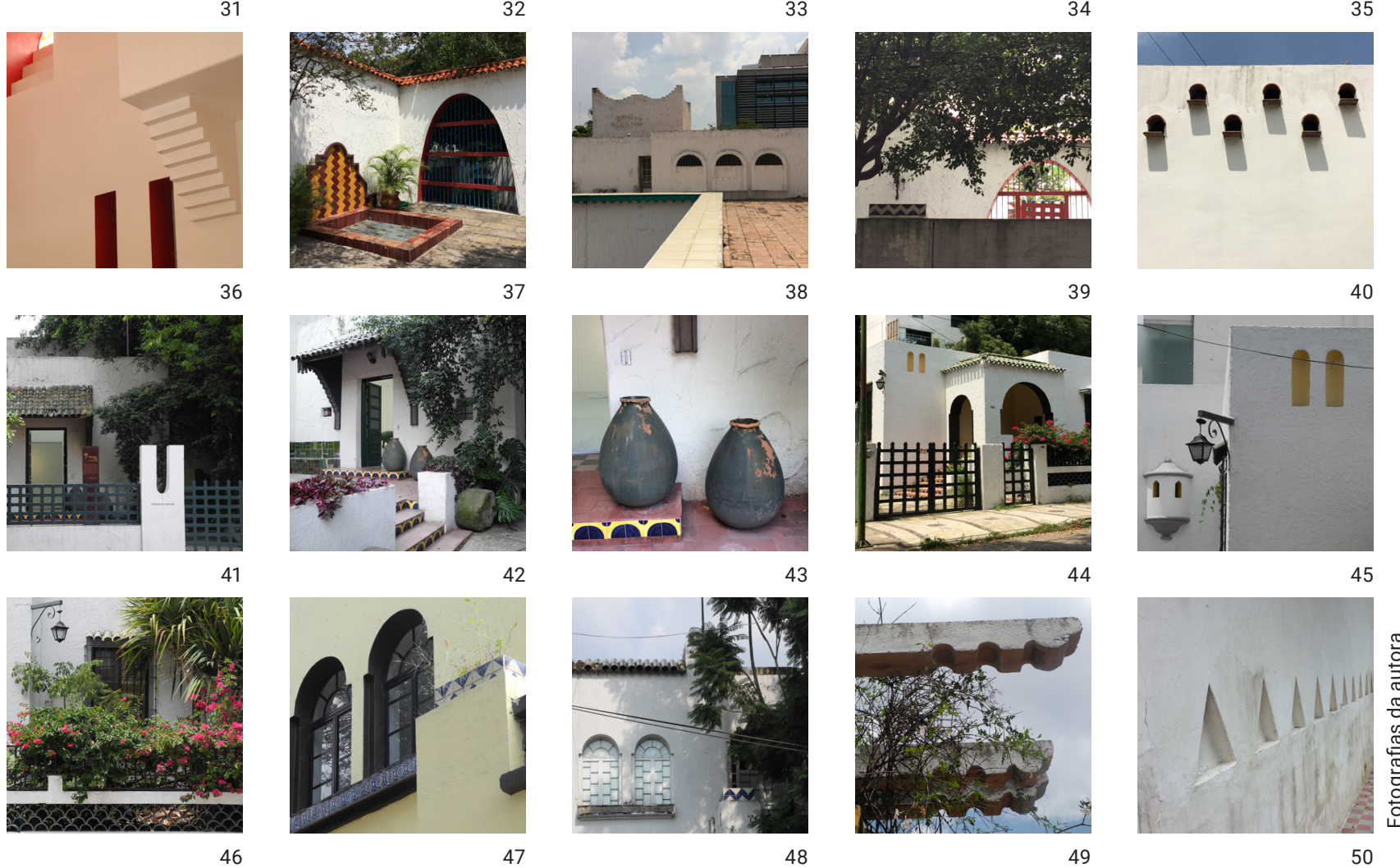

Conjunto de obras de Luis Barragán em Guadalajara, 2017
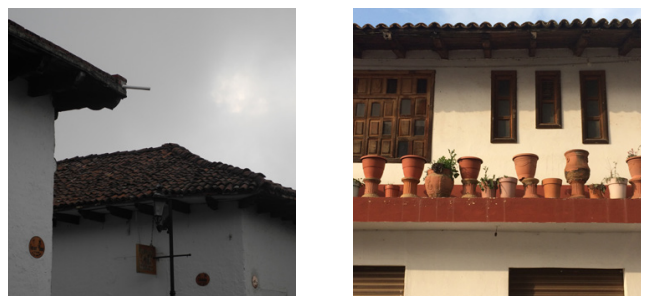

52

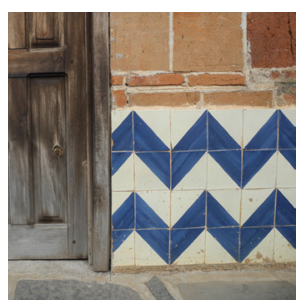

53
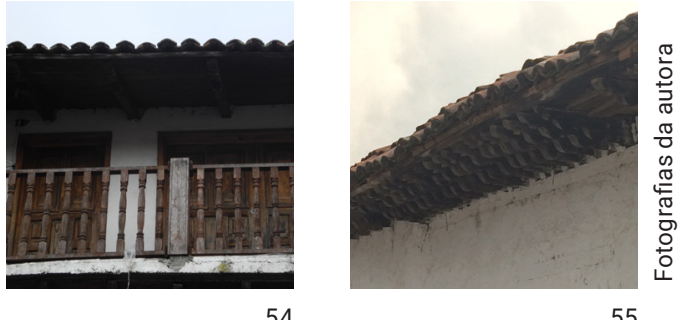

55 
Declarada patrimônio artístico pelo INBA (Instituto Nacional de Belas Artes ${ }^{17}$ ) desde 2006, e mantida pela ITSEO ${ }^{18}$ - Universidade Jesuíta de Guadalajara - desde 2001, a casa encontra-se em excelente estado de preservação. Atualmente funciona como um centro cultural e foi renomeada como Casa Clavigero, em homenagem ao jesuíta Francisco Xavier Clavigero ${ }^{19}$ (1731-1787) pelo seu trabalho com os indígenas e a favor de independência cultural dos mexicanos. A casa está localizada na rua José Guadalupe Zuno 2083, no bairro Americana, uma área predominantemente residencial. A casa foi projetada e construída para Efraín González Luna (18981964), influente intelectual, ativo politicamente em Guadalajara, tradutor de Kafka e Joyce, que participou ativamente da revista Bandera de Provincias ${ }^{20}$. Através dos encontros da revista estabeleceu amizade com o jovem arquiteto Barragán (ZANCO, 2002, p. 49). González Luna viveu na casa com sua família até 1964.

Implantada em um lote profundo, o terreno de $1750 \mathrm{~m} 2$ ocupa toda a extensão da quadra. Barragán toma partido das diferentes cotas de níveis entre as ruas adjacentes e implanta platôs escalonados para vencer esse desnível ao longo do terreno. Pelas duas ruas é possível o acesso à casa através de jardins. Composta por blocos e pátios, a volumetria relembra uma ilustração de Ferdinand Bac, com desníveis, pórticos e fontes. 0 acesso principal, com orientação norte, se dá a partir de um percurso da rua até o volume edificado composto por um pequeno jardim e um espelho d'água no formato quadricular já um pouco elevado em relação ao nível da rua. Uma escada conduz diretamente ao nível superior, para a biblioteca, para a capela particular de González Luna e para o terraço-jardim, num acesso independente e, pelo vestíbulo, conformado por um pórtico com arcos, há uma porta de madeira detalhada e demarcada, levando diretamente para a área social. Neste vestíbulo há um jogo de luz, e a cor azul do teto lava todo o ambiente de azul, em uma espécie de filtro entre fora e dentro. A construção segue em um eixo longitudinal norte-sul, onde do lado leste encontram-se os dormitórios que comunicam-se entre si orientados para um pátio na lateral, e do lado oeste encontram-se a cozinha e áreas de serviços com acesso ao pátio posterior. No pavimento superior, o eixo está marcado por uma pérgola de concreto localizada no terraço-jardim, conformando uma área sombreada entre o lado externo e o interno da casa. A partir do terraço jardim é possível ter vista para os jardins circundantes da casa e contato com o céu. Também há um acesso interno ao nível superior, através de uma escada, conformando o volume mais alto da edificação. Esta escada interna conecta-se com a escada externa através de uma porta, em um dos patamares. Os materiais utilizados na casa são típicos da região de Jalisco: paredes de adobe e pinturas de cal, pisos de pedra, ladrillo perón (tijolo de barro) e madeira. Elementos tradicionais das casas tapatías. 0 domínio dos detalhes é evidente, toda a marcenaria é trabalhada em ricos detalhes: guarda corpos, portas de madeira maciça, biombos. 0 desenho da marcenaria faz parte do todo. As aberturas são estrategicamente posicionadas e trabalhadas de diversas maneiras de modo à filtrar a luz: zenitais, janelas altas, semicirculares, quadradas, retangulares e não permitem uma vista direta ao exterior. São anexados vidros soprados com figuras geométricas e elementos vazados de madeira oferecendo em cada ambiente uma atmosfera distinta. A luz é difusa tornando a casa em um
17. Órgão cultural do governo mexicano cujo objetivo é preservar e difundir o patrimônio artístico do México. Site oficial: http://www.inah. gob.mx/es/

18. Instituto Tecnológico y de Estudios Superiores de Occidente. Site oficial: https://www.iteso.mx/

19. Autor de Historia Antigua de México, 1789.

20. A Casa González Luna foi projetada e construída durante o período da guerra cristera em Jalisco (1926-1929), conflito armado entre os católicos e o Governo. (ALFARO, 1996, p. 62 e 63). 
ambiente introspectivo. A luz define a qualidade do espaço e é distinta de acordo com cada estação do ano. As sombras das árvores nos jardins e nos pátios oferecem um micro clima, protegendo das altas temperaturas de Guadalajara. Barragán trabalha o desenho dos pisos externos, e a relação entre interior e exterior expressa em toda sua obra que se inicia já neste momento (ZANCO, 2010, p. 35). As estratégias projetuais de Barragán através de elementos como escadas externas, pátios, fontes aparecem já nesta primeira casa e se desdobra recorrentemente em toda sua obra. Em 1930 González Luna convida Ignácio Díaz Morales para realizar a ampliação da casa, anexando uma sala de música, dois dormitórios e um banho em um volume transversal à construção existente. E no pavimento superior, a ampliação da biblioteca e do terraço jardim.

É possível identificar no conjunto de obras nesta primeira fase a recorrência dos seguintes procedimentos: o desenho da luz, a presença da água, a dimensão cromática e o uso de elementos vernáculos nos projetos de Luis Barragán.
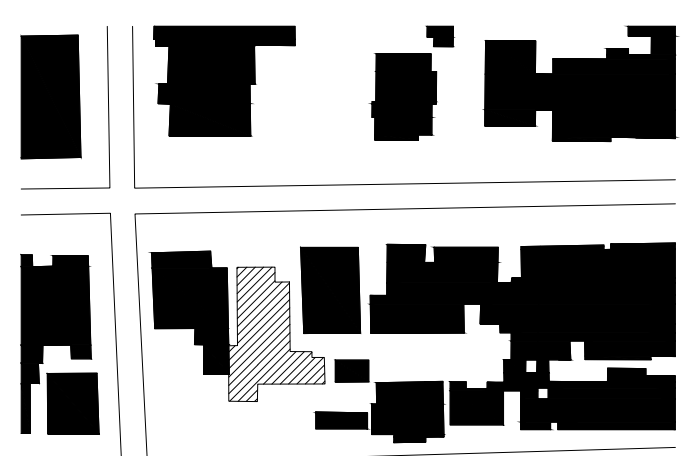

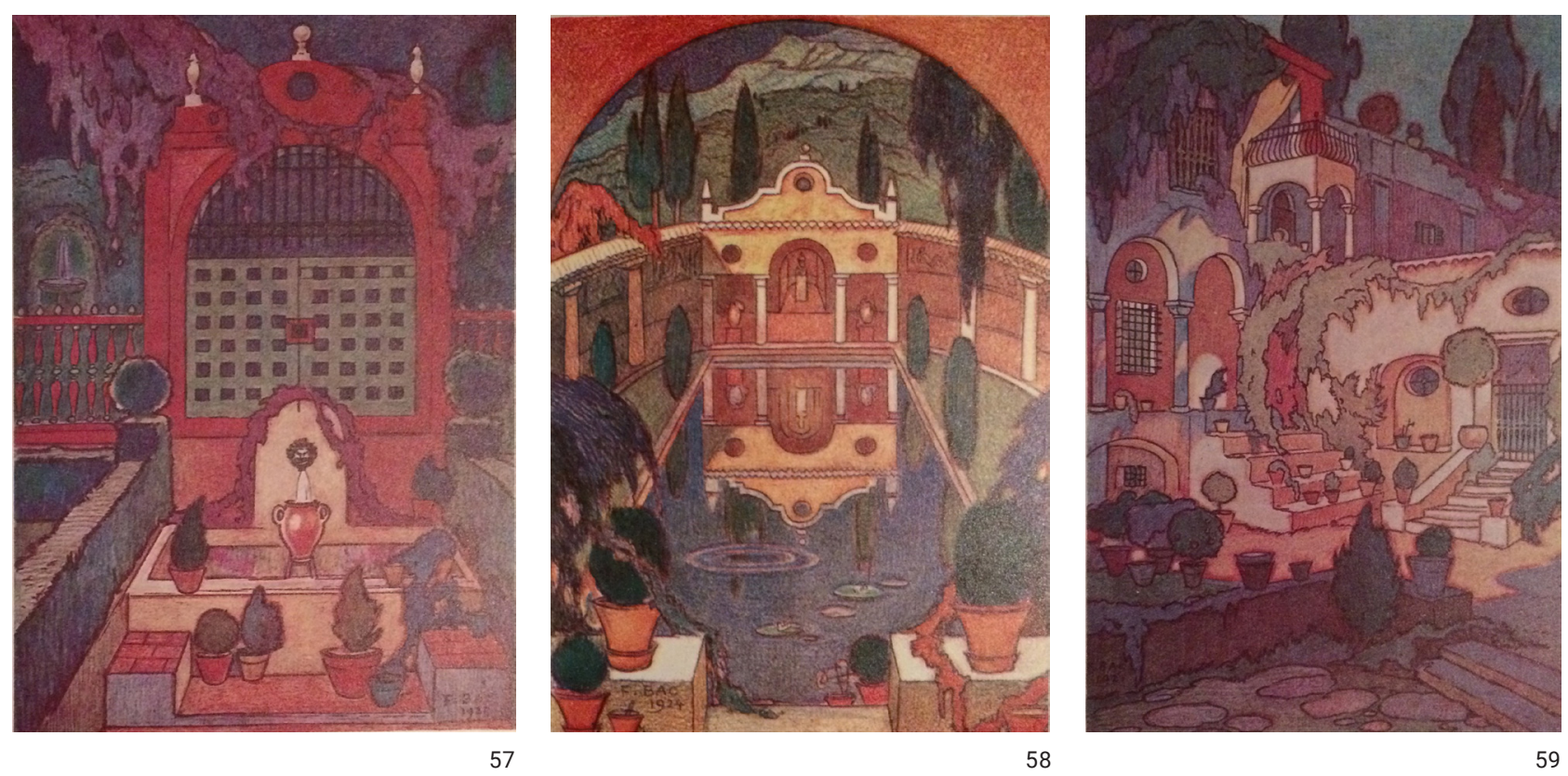


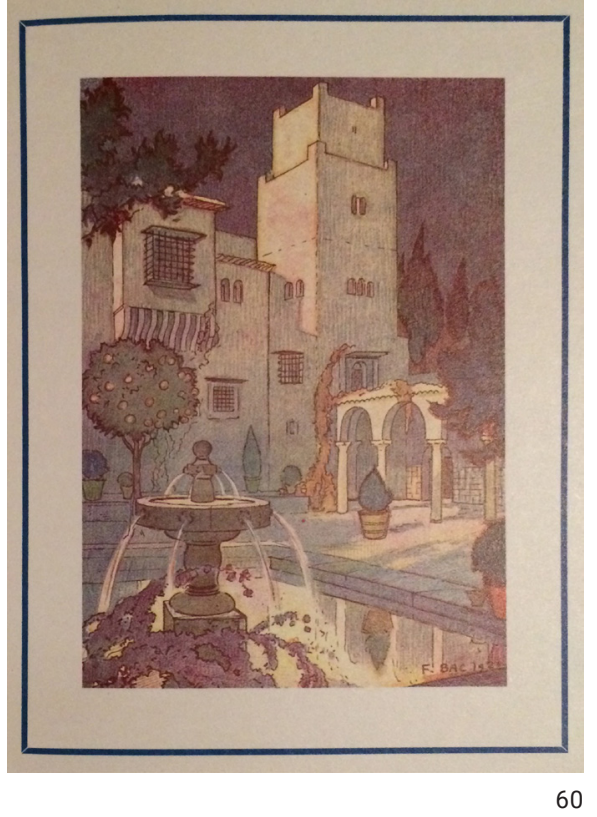

Ilustração de Ferdinand Bac, 1925 


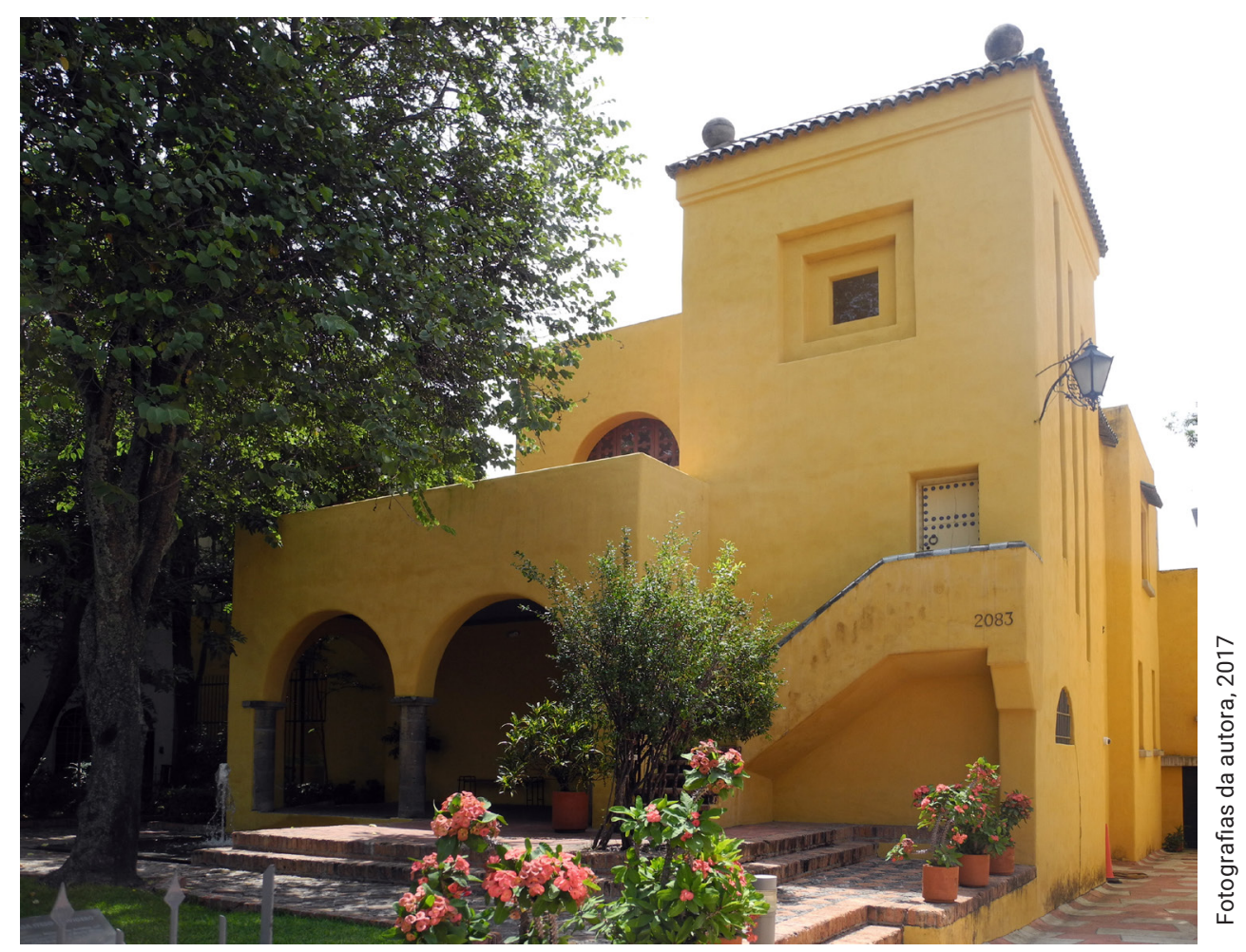

61 


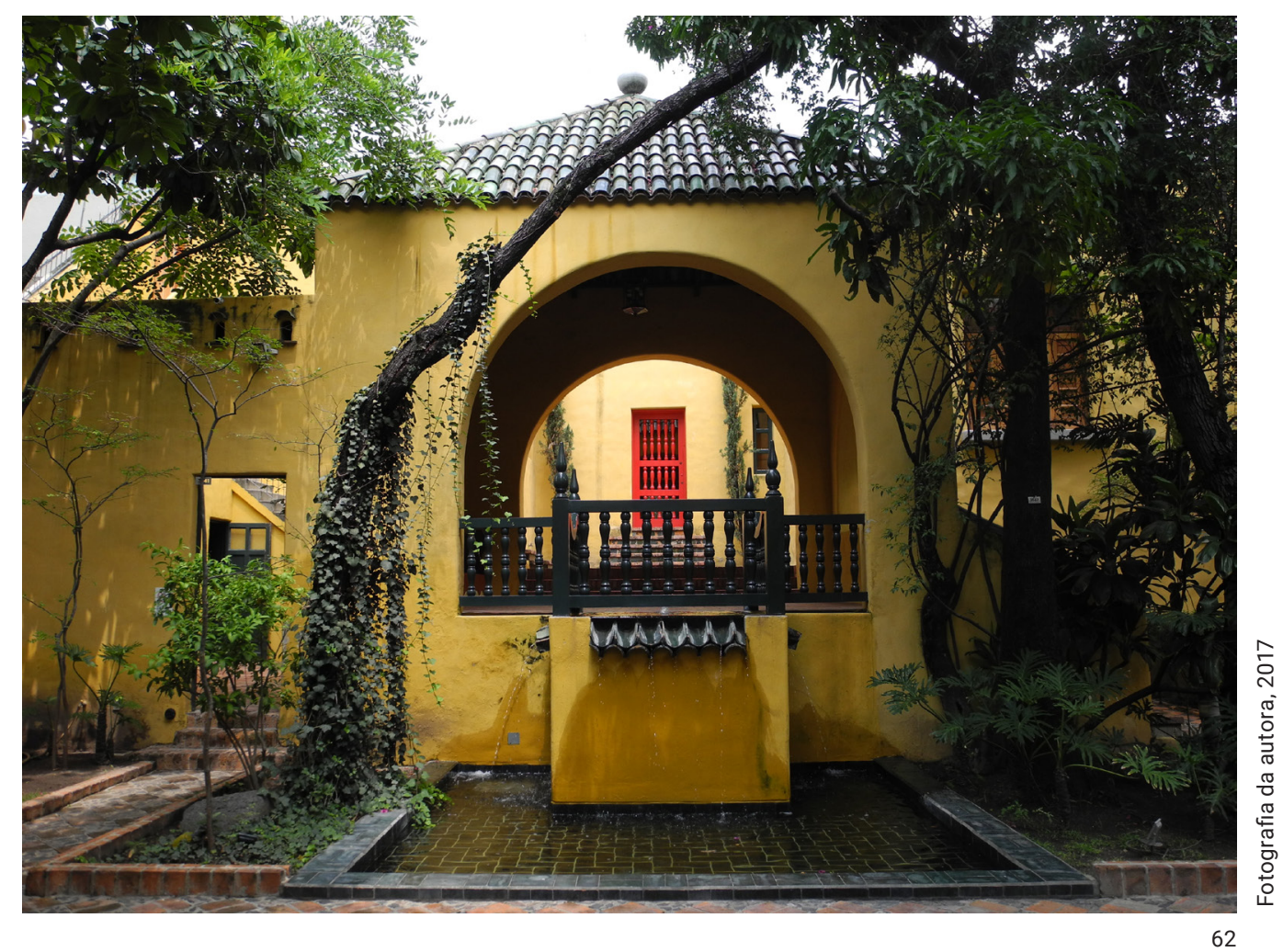



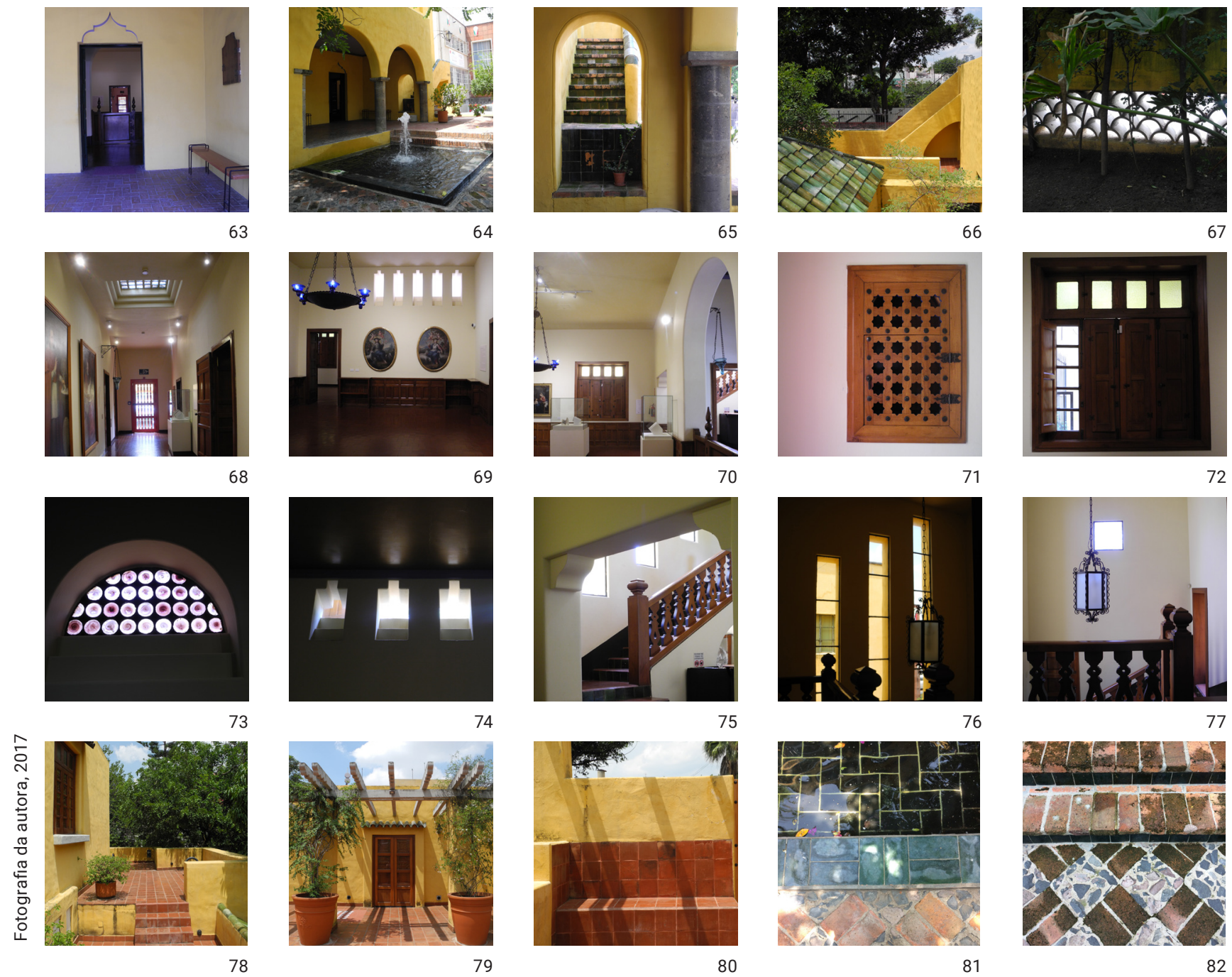

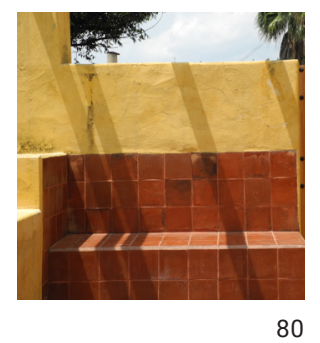

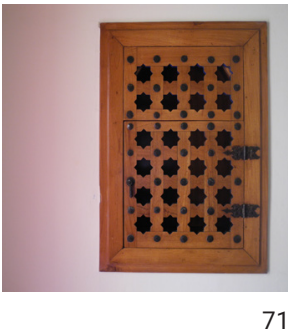

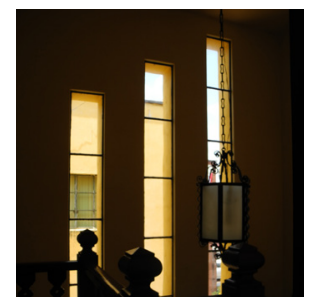

67
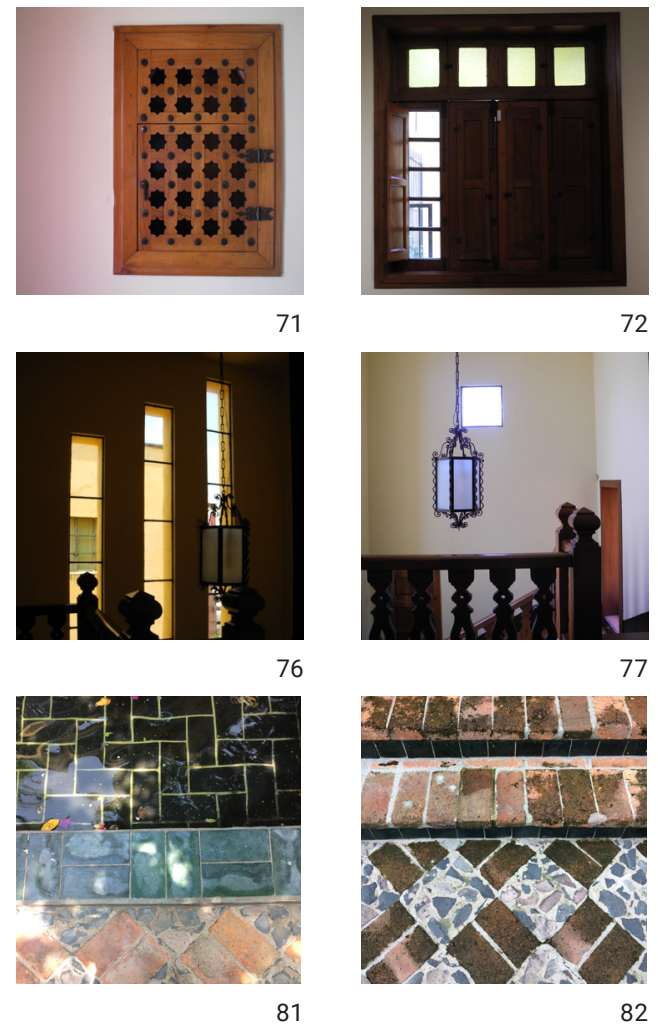



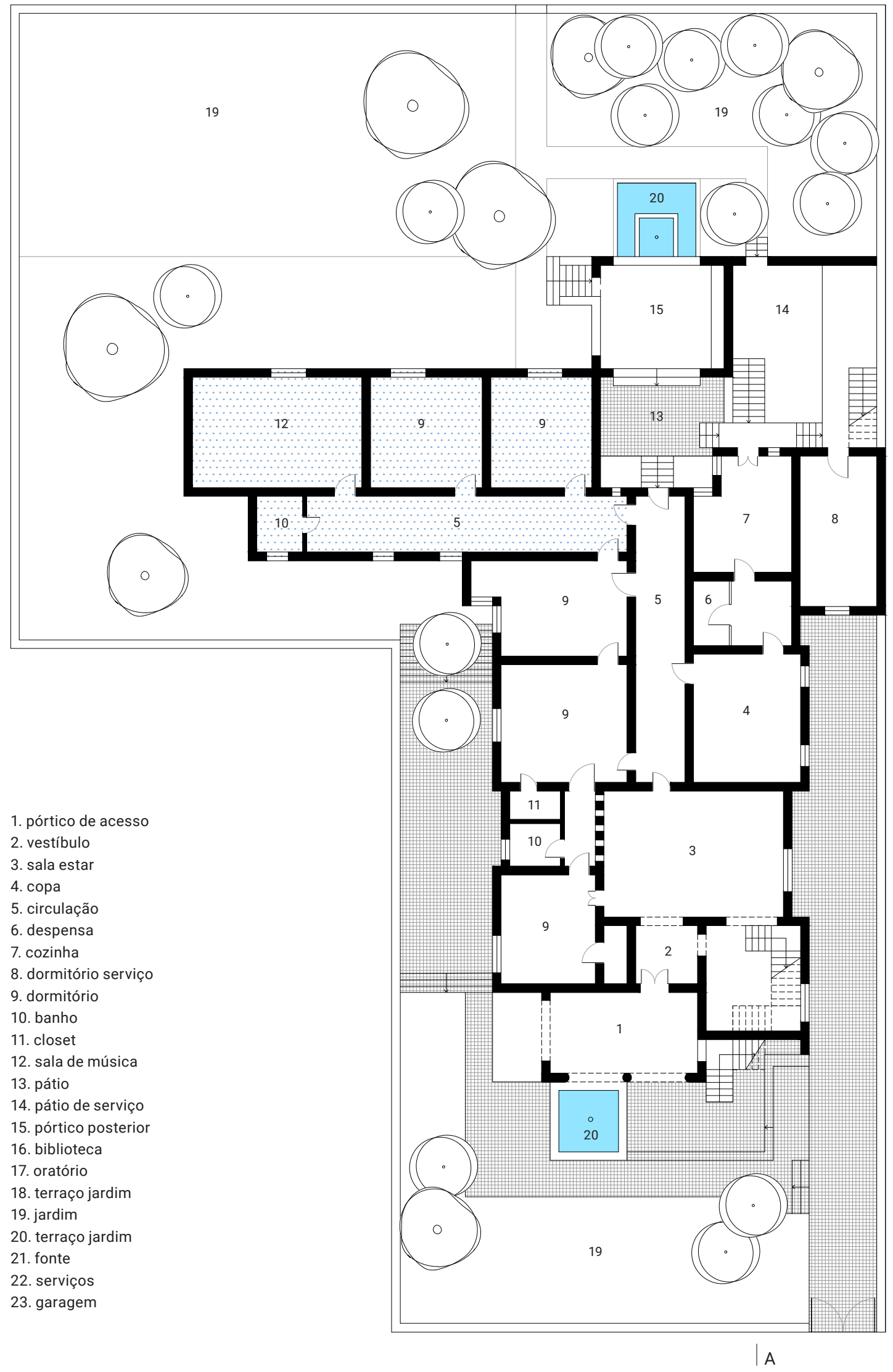

Rua José Guadalupe Zuno Hernández

planta térreo

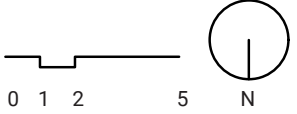



|A

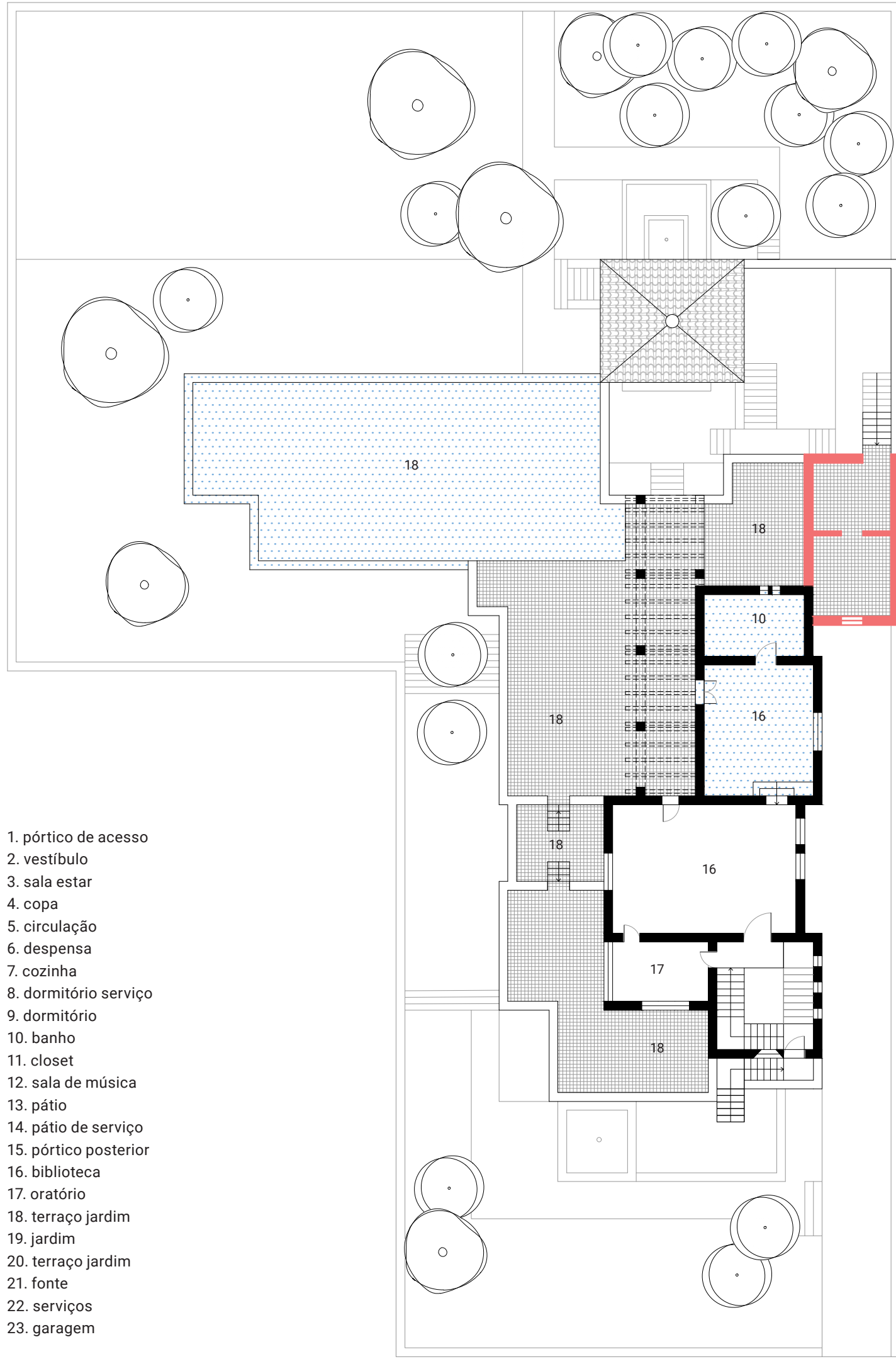

IA

planta pavimento superior

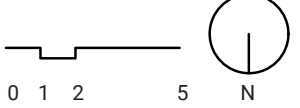





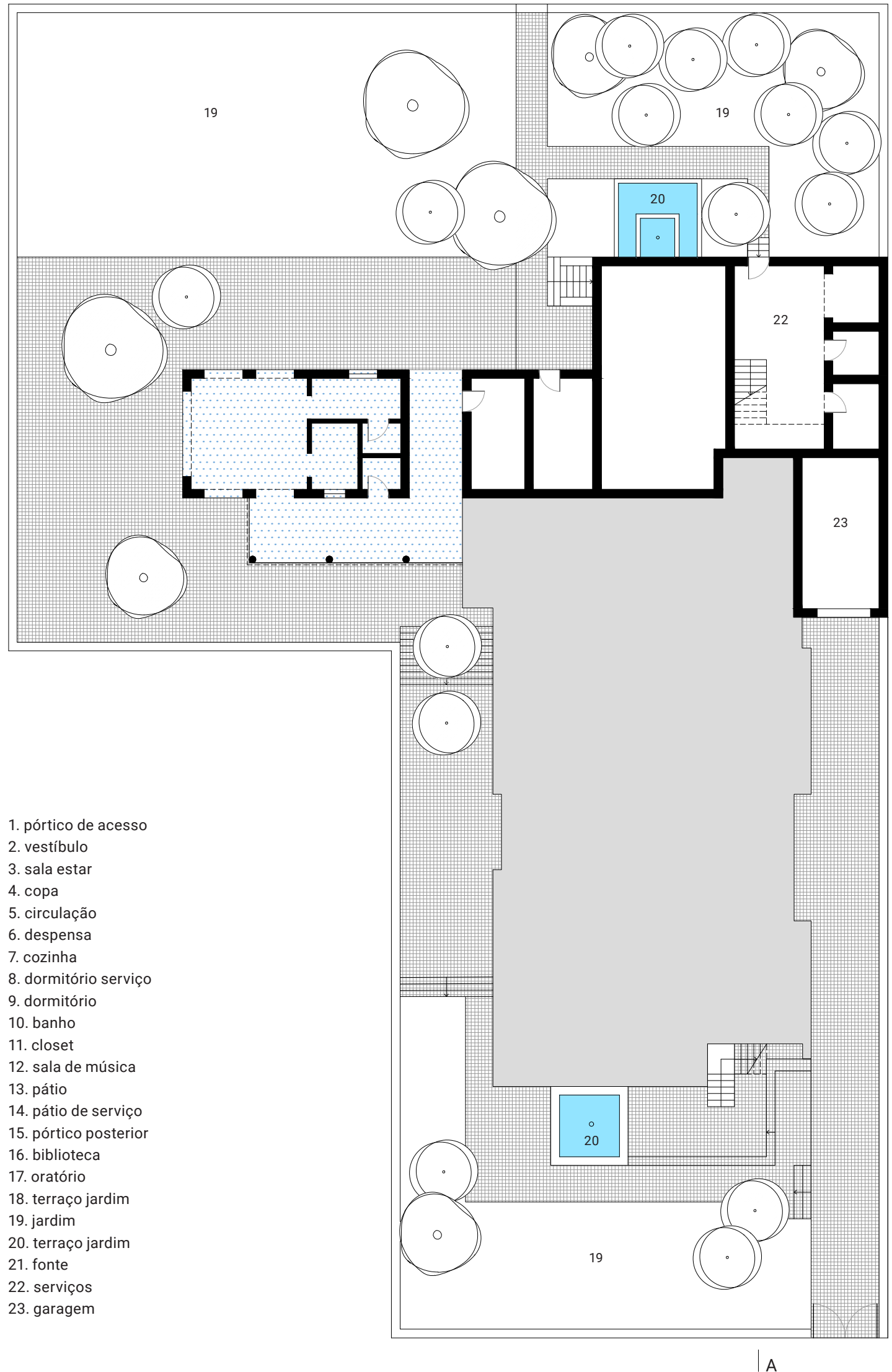





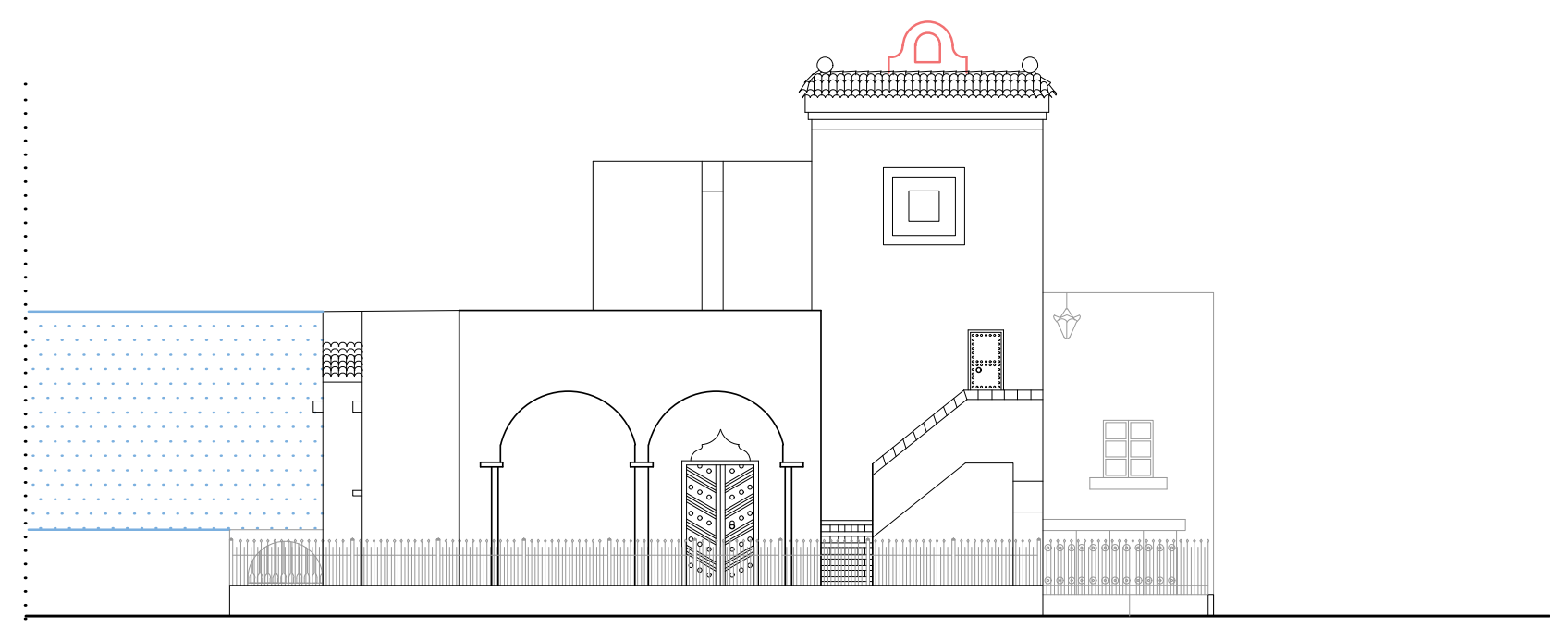

fachada norte

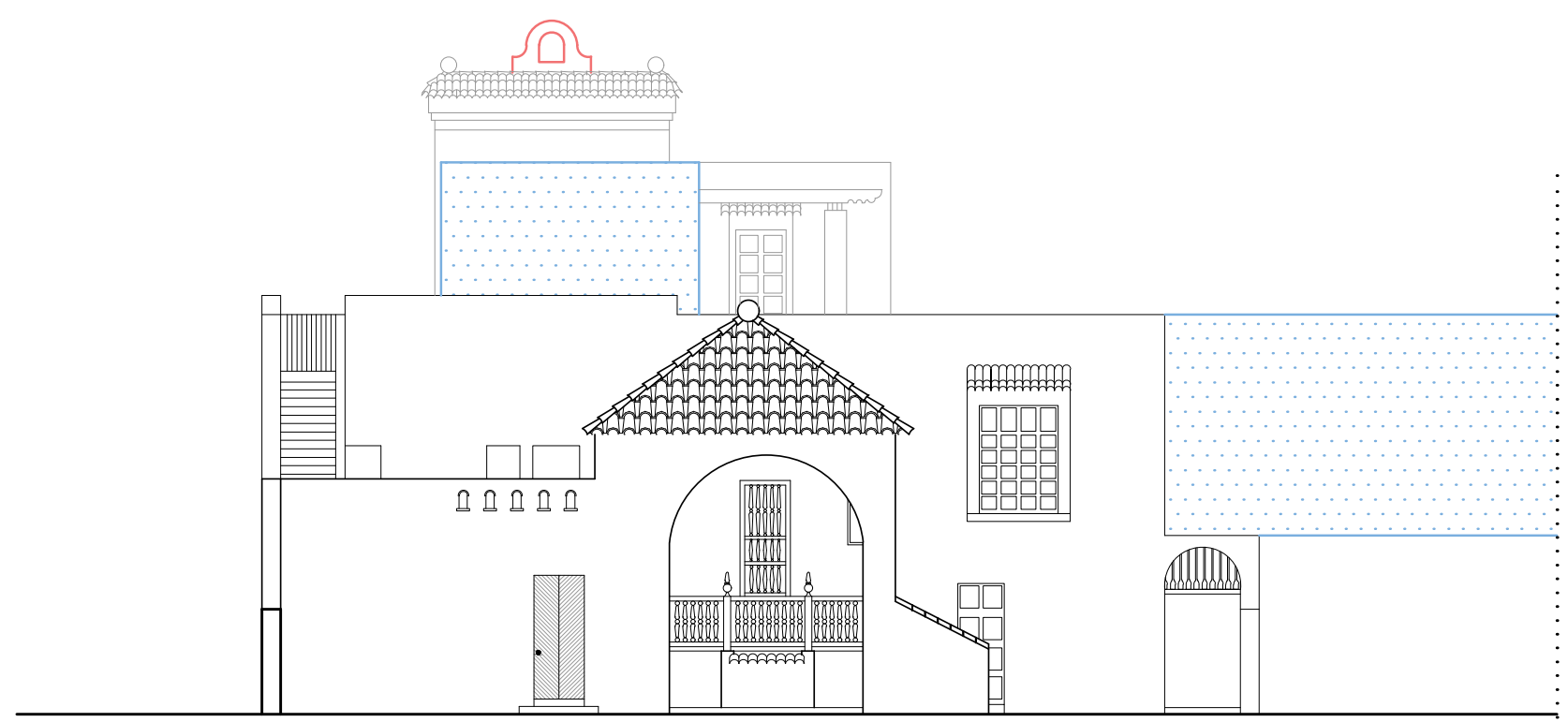

fachada sul

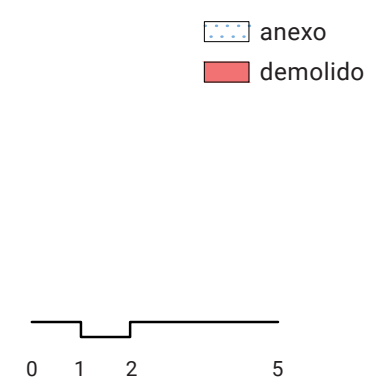




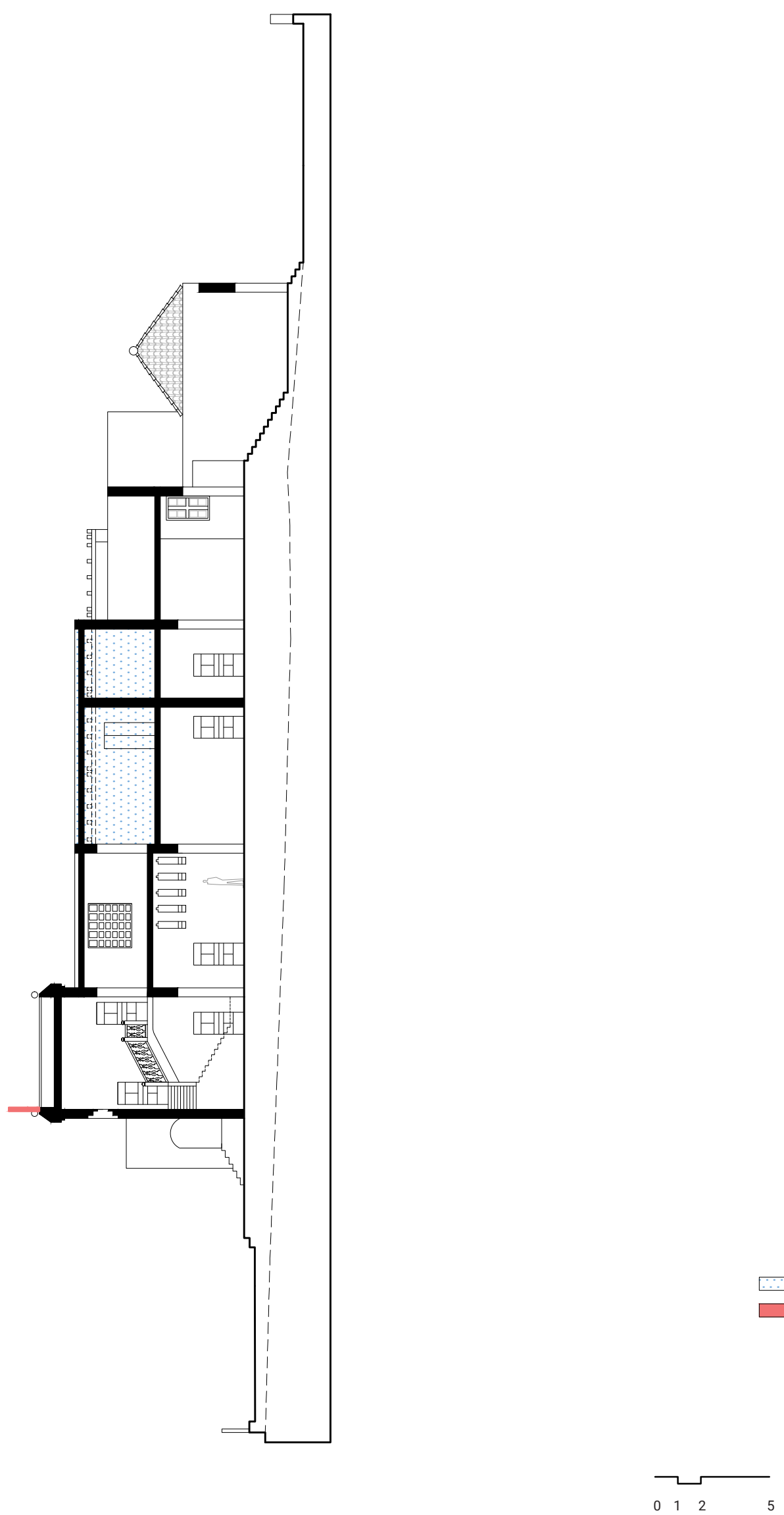

$\therefore$ anexo

demolido

corte A 


2. Segunda fase 1936-1944 
Estoy lejos de entender todo lo que está pasando. El pasado y el presente siguen en lucha. Lo moderno aquí va muy rápido. Quiero llevarme en el corazón este espíritu y revisar este arte. Cuando todo este ruido esté lejano, sus ideas me serán más claras. Me podrán servir para una línea de arte, distinta a la estacada ya desde hace tiempo. (BARRAGÁN, 1931, p. 17)

\subsection{Viagens à Chicago e Nova lorque e o retorno à Europa}

No ano de 1871 a cidade de Chicago sofre um enorme incêndio devastando grande parte das construções existentes. Conformada como uma das maiores cidades norte-americanas neste momento com 300000 habitantes, representava um dos polos econômicos do país. A cidade configurava-se como um grande entreposto de madeira, onde armazéns, residências e comércios eram construídos com esse material. Como resposta rápida ao desastre, a reconstrução da cidade foi feita através de novas técnicas construtivas, que contemplavam o uso de estruturas de aço e de concreto armado na construção dos edifícios conformando uma nova morfologia urbana verticalizada. A "Escola de Chicago" surge neste momento de reconstrução da cidade, na qual os arranha-céus começavam a surgir representando uma nova cultura arquitetônica condizente ao contexto econômico. O uso de novas técnicas construtivas junto com o desenvolvimento do elevador elétrico possibilitou a construção de edifícios cada vez mais altos (BENEVOLO, 1976, p. 233). William Le Baron Jenney (1832-1907), William W. Boyington (18181898) e J.M. van Osdel (1811-1891) foram os primeiros engenheiros a trabalharem com a reconstrução da cidade e Daniel H. Burnham (1846-1912), John Root (1850-1891), William Holabird (1854-1923), Martin Roche (1855-1927), Louis Sullivan (1856-1924) e Dankmar Adler (1844-1900) foram os principais representantes deste movimento.

1. "Estou longe de entender tudo o que está acontecendo. 0 passado e o presente seguem em luta. O moderno aqui vai muito rápido. Quero levar no meu coração este espírito e revisar esta arte. Quando todo este ruído estiver afastado, estas ideias serão mais claras. Poderão me servir para uma linha de arte, distinta da que está estancada já faz tempo". (BARRAGÁN 1931, p. 17, tradução da autora).

2. Após três meses em Chicago falece seu pai e Barragán retorna à Guadalajara assumindo os negócios da família em Jalisco.

Luis Barragán viaja à Chicago em 1930 acompanhando seu pai com problemas de saúde ${ }^{2}$ e se depara com uma cidade moderna construída em grande parte a partir de invenções técnicas aplicadas nos edifícios desenvolvidas através do uso de estrutura em aço e concreto armado. No México, neste período, não existiam construções deste tipo.

Um ano depois dessa viagem, aos 28 anos, Luis Barragán viaja mais duas vezes. Primeiro passa três meses em Nova Iorque, e depois retorna à Europa. Neste 
período, em Nova Iorque, José Clemente Orozco, estava realizando um ciclo de murais para a New School for Social Research, e Barragán estabelece uma forte amizade com o pintor. Conhece também nessa viagem, através de José Clemente Orozco, o arquiteto austríaco Frederik Kiesler (1890-1965), que neste momento acabava de projetar e construir uma sala de cinema experimental em Nova lorque, a Film Guild Cinema, 1929. Arquiteto vanguardista com forte interesse na relação entre escultura, pintura e arquitetura. O Film Guild Cinema foi uma das obras selecionadas para a exposição "Modern Architecture International Exhibition" e da célebre publicação "The International Style: Architecture since 1922", no MoMA em 19323. Barragán projeta entre 1935-1936 em Guadalajara uma sala de cinema, o Cine Jalisco, onde são tomadas claramente lições de arquitetura de Kiesler. Barragán comenta a importância dessas relações em uma entrevista para Alejandro Ramírez Ugarte realizada em 1962:

Las conversaciones con Kiesler fueron para mí muy interesantes [...] la ruta del funcionalismo estaba bien marcada, pero un funcionalismo que Kiesler entendió muy bien; quiero decir, funcionalismo de la función construcción cómo máquina para que el hombre la use, pero también la función para que el espíritu se desarrolle y viva agradablemente. Así que tuve esa conexión personal que fue buena. (BARRAGÁN, 1962, p. 78) ${ }^{4}$

Aproveita a viagem para fazer contatos e conhece Lawrence Cocker, editor da revista The Architectural Record, entre outros editores de outras revistas de arte e arquitetura. Barragán já pensava na difusão e promoção de suas obras.

No retorno à Europa, em 1931, Luis Barragán conhece pessoalmente Le Corbusier (1887-1965) que propõe à Barragán uma visita à Villa Savoye, indicando com um desenho como chegar na casa:

Fui al pueblo de Poissy a ver una casa de Jeanneret, muy moderna, me ha parecido una bella escultura. El paisaje a su alrededor sirve de mesa verde, se me figura sus bellos cuadros [...] Todos hablan de él, y yo apenas he leído unas cuantas cosas, aunque ya encargué a un librero todo lo que este publicado. Pude hablar con él, muy poco, y me dibujó el camino a la villa. Marie me dice que le hizo a un tal de Beistegui un proyecto por Campos Elíseos. Tengo curiosidad por ver lo que hizo a este paisano en París. A mi me gustan sus cuadros. (BARRAGÁN, 1931, p. 17) 5
3. Organizada por Philip Johnson e Henry-Russel Hitchcock.

4. "As conversas com Kiesler foram para mim muito interessantes [...] o caminho do funcionalismo estava bem marcado, porém um funcionalismo que Kiesler entendeu muito bem; quero

dizer, funcionalismo da função da construção como máquina para que o homem a use, mas também a função para que o espírito se desenvolva e viva agradavelmente. Assim tive essa conexão pessoal que foi boa". (BARRAGÁN, 1962, p. 78)

5. "Fui ao povoado de Poissy para ver uma casa de Jeanneret, muito moderna, me pareceu uma bela escultura. $A$ paisagem ao seu redor serve de mesa verde, me lembrou seus belos quadros [...] todos falam dele, e eu apenas li algumas coisas, e pedi para um livreiro guardar tudo o que foi publicado dele. Falei com ele, muito pouco, e ele me desenhou o caminho para à Villa. Marie me falou que ele fez para um tal Beistegui um projeto em Campos Elíseos. Tenho curiosidade em ver o ele fez para este compatriota em Paris. Eu gosto de suas pinturas". (BARRAGÁN, 1931, p. 17, tradução da autora) 

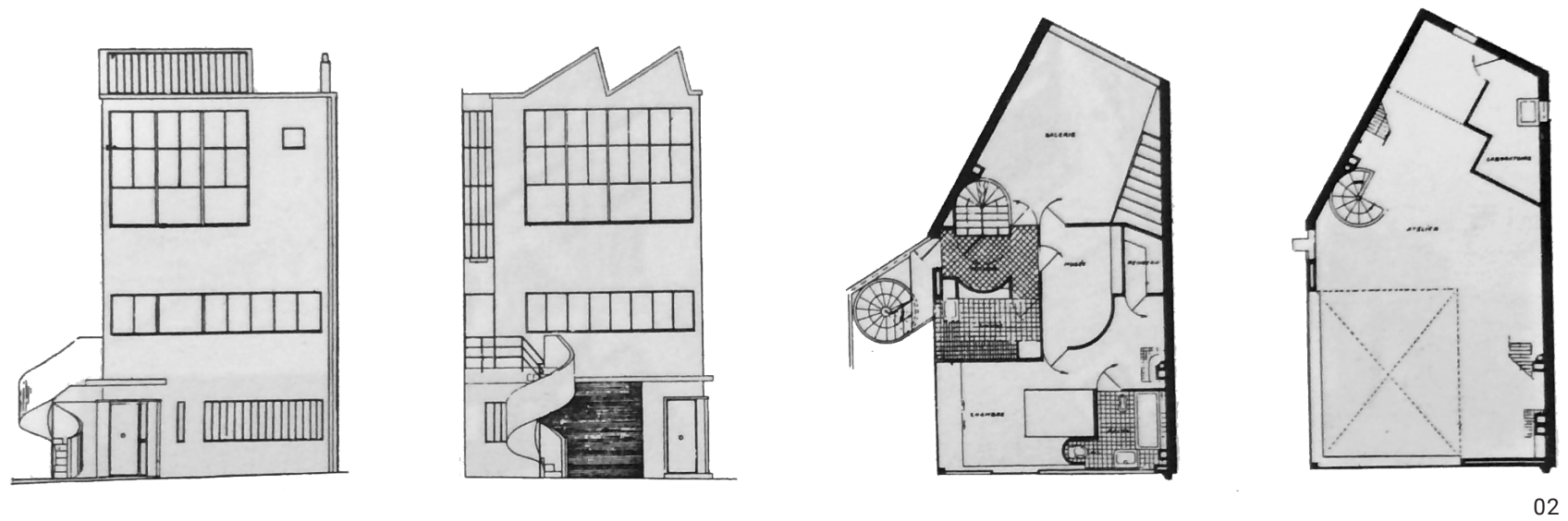
Barragán conhecia a arquitetura moderna através das publicações que chegavam ao México e nesta viagem, toma contato com essa arquitetura, visitando também o ático projetado por Le Corbusier para Carlos Beistegui nos Campos Elíseos (Carlos Beistegui era de nacionalidade mexicana e vivia em Paris).

Le Corbusier, que já havia passado por escritórios da vanguarda europeia na Áustria, França e Alemanha (colaborando com Josef Hoffman, August Perret, Peter Behrens e Heinrich Tessenow), e vindo de uma formação inicial na Escola de Artes e Ofícios em sua cidade natal La Chaux-des-Fonds na Suíça (e sem adentrar em suas viagens de estudo pela Europa e Oriente), neste momento já começava a cruzar em sua obra arquitetura, pintura e escritos. Perret lhe havia introduzido o uso do concreto armado nas construções e a teoria do racionalismo francês de Auguste Choisy, Eugène Viollet-le-Duc e de Abade Laugier e sua experiência laboral com Behrens lhe mostrou a relação entre arte e a máquina, e a necessidade de produção em série (CURTIS, 1982, p. 164). Em 1914, Le Corbusier elabora o projeto "Maisons Domino" conformando um sistema estrutural independente a partir da estrutura de concreto armado para a execução de casas em série. Esta invenção é para Le Corbusier guia para muitos outros projetos deste período.

$O$ encontro de Le Corbusier com o pintor Amedée Ozenfant (1886-1966) em 1917 Ihe abriu novos caminhos (como a pintura) e juntos conformaram em 1920, a revista artística e literária L'Esprit Nouveau trazendo a luz o debate da vanguarda nos campos da arquitetura e da pintura. Le Corbusier surge como um pseudônimo para Charles Edouard Jeanneret e Saugnier para Amedée Ozenfant ao assinarem os artigos da revista. Le Corbusier e Ozenfant já haviam escrito "Depois do cubismo" em 1918, como um manifesto e conformação do purismo. Na introdução da edição em português deste livro, Carlos Martins comenta que Ozenfant e Le Corbusier vinham de trajetórias distintas, mas compartilhavam alguns interesses em comum, entre eles, o modernismo industrial e o gosto pela arte antiga.

O purismo se configura neste contexto do final da Primeira Guerra Mundial, e segundo Carlos Martins, o movimento queria expressar a característica essencial do espírito moderno (MARTINS, 2005, p. 17). 0 impacto das máquinas, a indústria moderna, o uso do concreto, aço e vidro. A série de villas puristas de Le Corbusier (Casa estúdio Ozenfant, 1922; Casa La Roche-Jeanneret, 1923 e Villa Sovoye, 1929, por exemplo), revelam o impacto das máquinas, a indústria moderna, o uso do concreto, aço e vidro em sua produção. Em 1926 elabora a obra "Os Cinco pontos para uma Nova Arquitetura", pensamento contínuo ao projeto "Maisons Domino" no qual define as seguintes premissas: o uso de pilotis, terraço jardim, planta livre, janelas contínuas e fachada livre. Sua arquitetura neste período se conformava a partir dessas premissas (CURTIS, 1982, p. 176). Sua produção pictórica neste momento tinha como tema objetos da vida cotidiana. Le Corbusier revela anos mais tarde a importância de seu labor secreto ${ }^{6}$, a pintura, ao valor de sua arquitetura.

6. Le Corbusier passa 30 anos sem expor sua produção pictórica ao público.

Luis Barragán conhece também neste retorno à Europa as cidades alemãs

Munique, Sttutgart e Berlim. Ernst May (1886-1970) faz o uso de cores intensas já nas casas populares na cidade de Frankfurt (1928) e nas casas Weissenhoff em Stuttgart (1927) (RICALDE, 1989, p. 121). Dentre as diversas vanguardas que 
aconteciam na Europa neste período, os neoplasticistas, por exemplo, também incluíam o uso de cor na composição de planos na arquitetura.

Nestes deslocamentos, atento aos acontecimentos e às novas construções no exterior, Luis Barragán se depara com uma cultura externa que o leva ao olhar interno. Este estranhamento com o moderno, ao mesmo tempo o encanta, faz com que Barragán entre uma nova fase de sua produção arquitetônica.

José Clemente Orozco surge como o primeiro cliente com ideais modernistas de Barragán, levando-o a projetar a casa e estúdio do pintor tanto em Guadalajara entre 1934, quanto na Cidade do México em 1940. Ambas as casas representam uma ruptura com os modelos de casas projetadas por Barragán em Guadalajara até então. Barragán se apropria de algumas premissas de Le Corbusier e na casa estúdio para Orozco em Guadalajara, por exemplo, faz uso de laje na cobertura, em diferentes níveis, conformando um jogo de volumes, uma espécie de terraço jardim escultórico que pode ser lido como um ensaio cubista na escala da arquitetura.

Orozco foi um dos interlocutores fundamentais dessa fase de Barragán, considerando que se transformou em um primeiro cliente, e um cliente que tinha toda uma afinidade com aquilo que Barragán estava procurando.
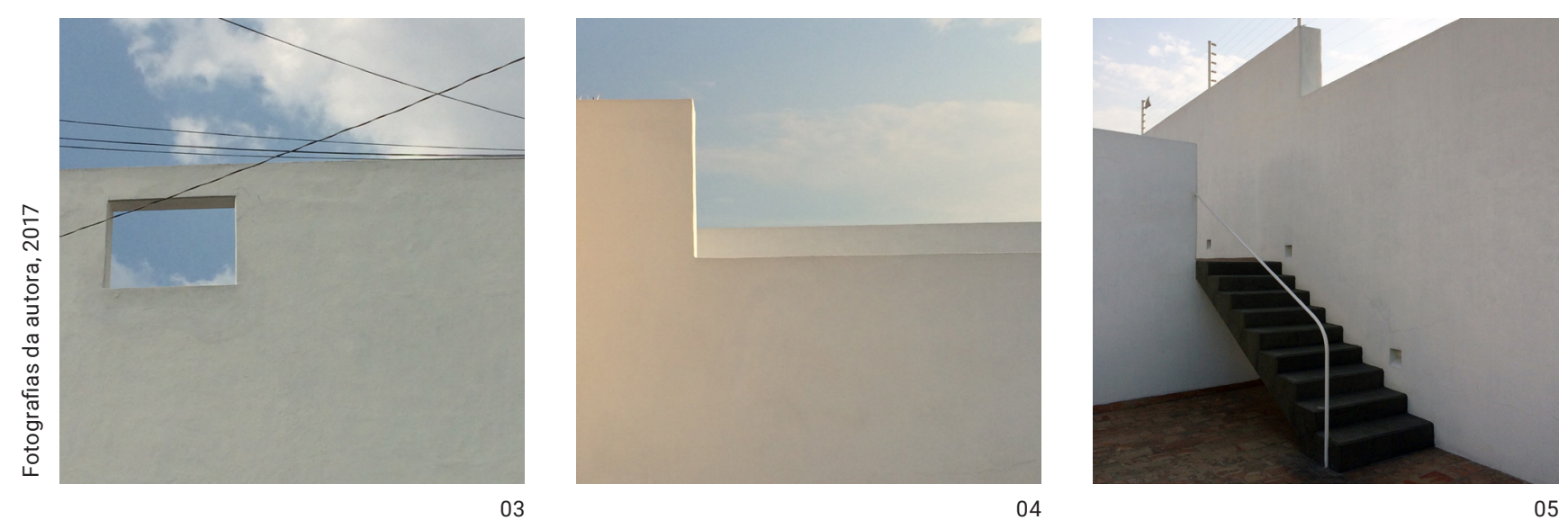

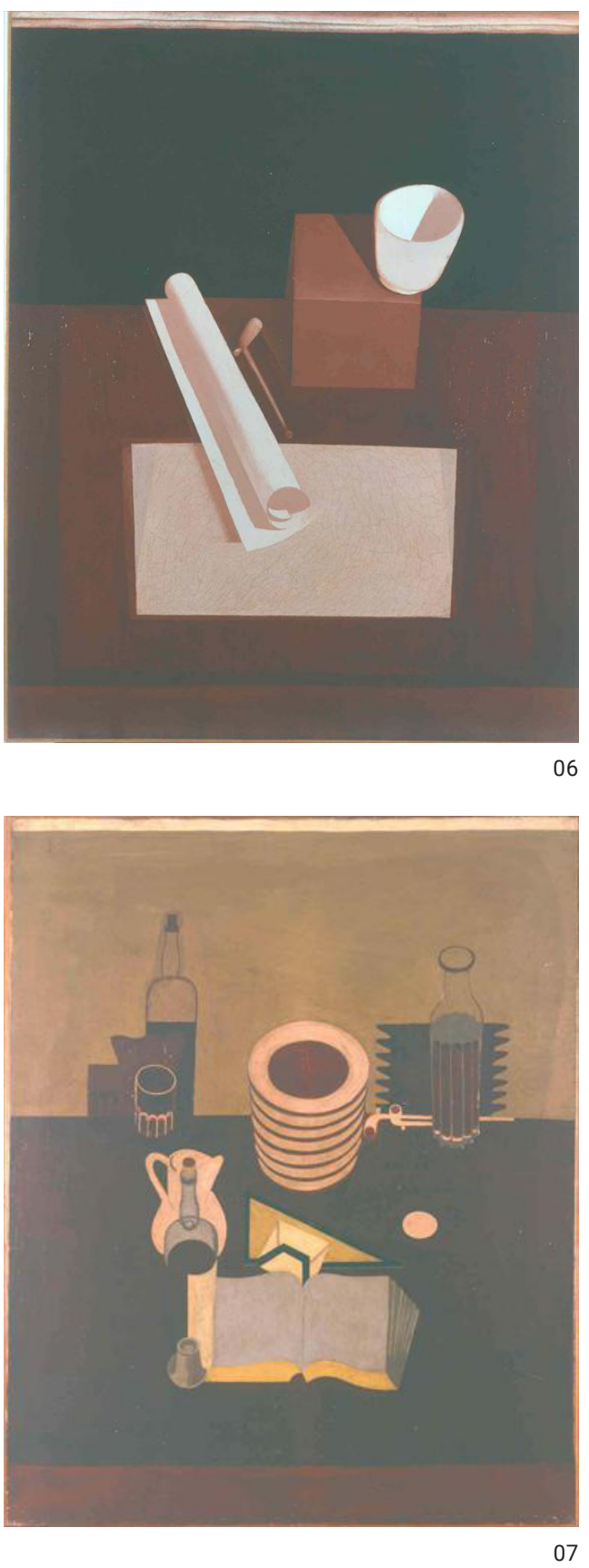

Le bol rouge, Le Corbusier, 1919

Nature morte à lóuef, Le Corbusier, 1919 

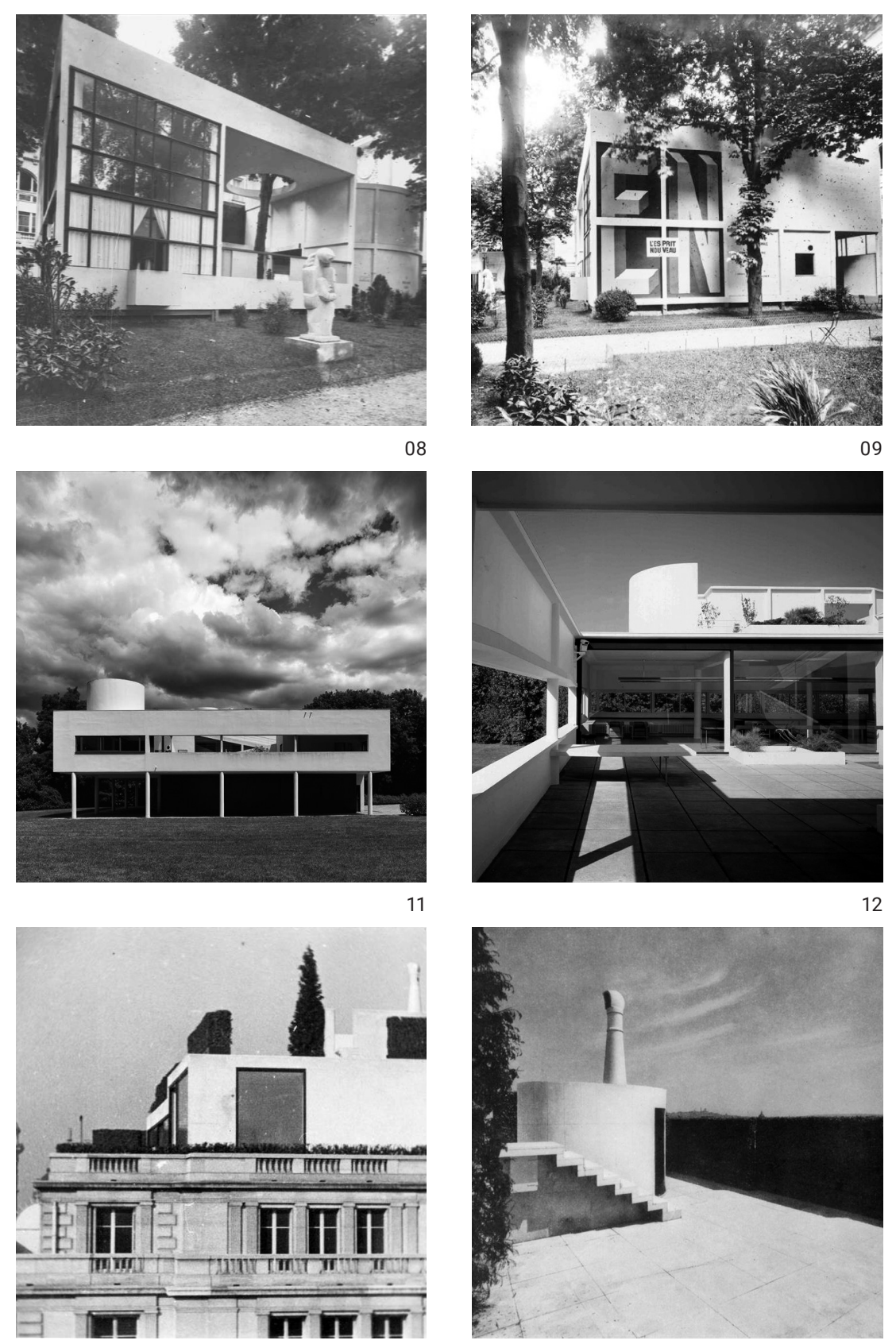

15
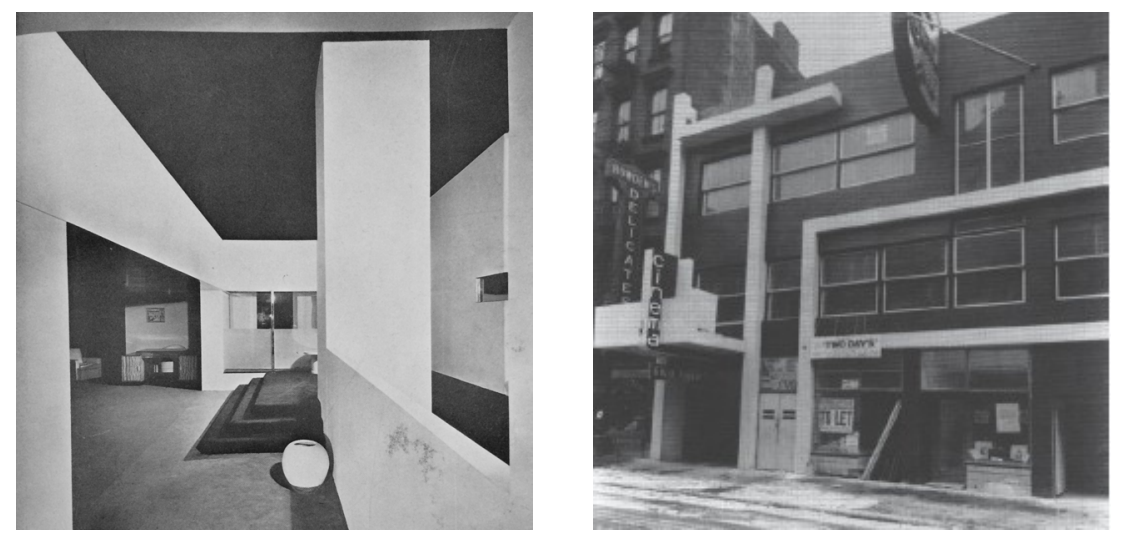

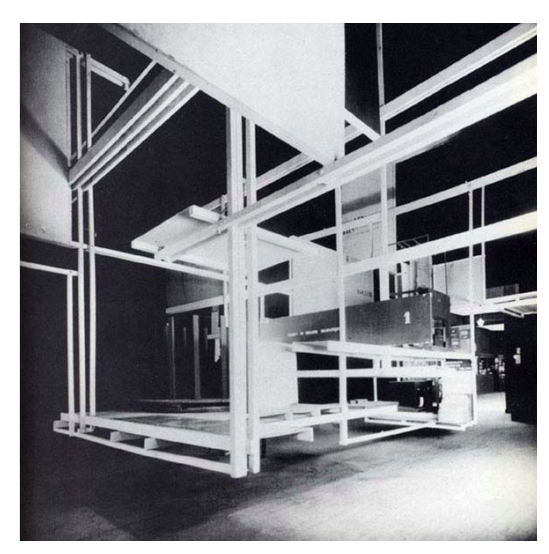

10
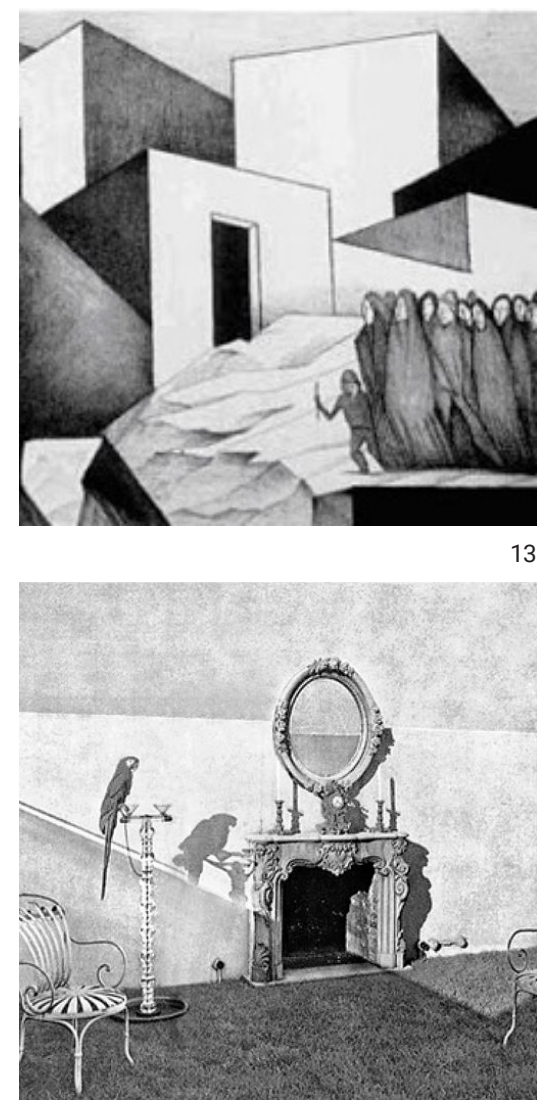

16

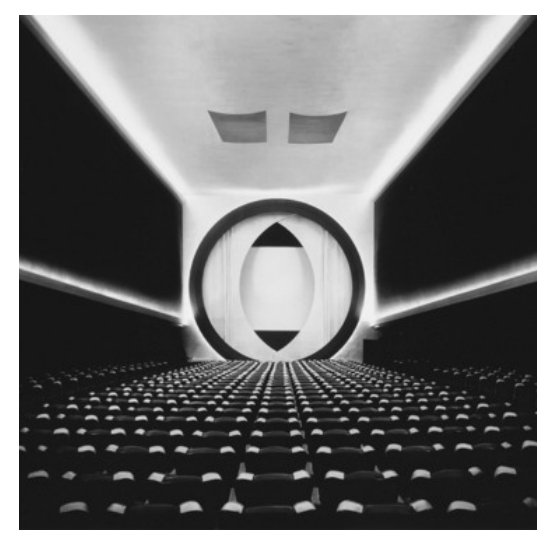

19

08 e 09. Pavilhão "L’Esprit Nouveau", Le Corbusier, Paris, 1925

10. Pavilhão "Cité dans L'Espace", Frederick Kiesler, Paris, 1925

11 e 12. Villa Savoye, Le Corbusier, Paris, 1929

13. El pueblo mexicano, José Clemente Orozco, 1930

14 a 16. Ático Carlos Beistegui, Le Corbuiser, Paris, 1930

17. Space house, Frederick Kiesler, Nova Iorque, 1933

18 e 19. Film Guild Cinema, Frederick Kiesler, Nova Iorque, 1929 


\subsection{Contextos históricos e culturais no México}

O debate entre temas relacionados à questão da tradição e das vanguardas na arquitetura mexicana permaneceram ao longo de muitas décadas do século XX. Enrique del Moral (1905-1987), um dos principais influentes da arquitetura moderna no México, por exemplo, traz a luz essa discussão através de artigo "Tradição versus modernidade" em 1980, escrito ao final de sua carreira profissional, investigando a relação entre esses limites na arquitetura mexicana durante todo este o período. Os representantes da arquitetura nacional passaram ao longo de suas vidas lidando com esses temas. Sob esse aspecto, a arquitetura moderna no México é composta por diversas vertentes. Se por um lado havia a busca de uma internacionalização, por outro, buscava-se a retomada do vernáculo para a construção de uma identidade nacional.

Após a Revolução, entre 1919 e 1920, a Cidade do México duplicou seu tamanho (ADRIÀ, 2016, p. 21). Com o plano urbano do bairro Hipódromo Condesa, de 1927, do arquiteto José Luis Cuevas (1881-1952), a arte decó e a arte nouveau ganharam expressão na conformação desses novos bairros. 0 bairro abriga diversos edifícios habitacionais modernos que não perderam o ornamento ou o detalhe artesanal. No centro do bairro foi projetado um jardim, atualmente Parque México, com autoria do arquiteto Leonardo Noriega e do engenheiro Javiér Stávoli. O jardim público contempla um teatro ao ar livre, um lago artificial e equipamentos urbanos como bancos, fontes e um relógio nas áreas ajardinadas e segundo Enrique X. de Anda, este projeto é um dos exemplos mais claros e vivos dos recursos estéticos promovidos pelo decó (ANDA, 1995, p.178). Ainda nas décadas de 1930 e 1940 continuavam-se construindo edifícios com essas expressões mantendo o uso do concreto armado com o qual passou a ser possível construir edifícios mais altos. É o caso do Edifício Basurto de 1945 de Francisco Serrano (1900-1982), próximo ao Parque México, e do Edifício Ermita de 1930 do arquiteto Juan Segura (1898-1989). 0 Edifício Ermita incorpora ao programa habitacional, o comércio no térreo e um cinema, seguindo uma linguagem composta por ornamentos (ANDA, 1995, p.179)7.

Em paralelo, no período entre as décadas 1920 e 1940, um grupo de intelectuais e artistas se preocupava em levar a cabo os reais propósitos da Revolução. Jovens arquitetos como Juan O'Gorman ${ }^{8}$ (1905-1982), Enrique del Moral (1905-1987), Juan Legarreta (1902-1934), Enrique Yánez (1908-1980), por exemplo, que foram alunos de Villagrán, neste momento respondem às demandas de construção através da vanguarda racionalista. Esse grupo de arquitetos estava comprometido principalmente ao funcionamento dos edifícios. A primeira casa modernista do México e comparada à Maisons Domino, 1914, de Le Corbusier, foi construída por Juan O'Gorman em 1929, para seus pais no bairro de Altavista na Cidade do México (LOBO, 2008, p. 10), conta com uma escada helicoidal de concreto do lado externo do volume edificado, conectando pavimento superior com o jardim, e com grandes janelas de vidro piso-teto. Legarreta constrói a sua própria casa em 1930, otimizando os espaços internos e eliminando qualquer tipo de ornamento, marcando uma ruptura com o modo de se fazer e pensar a arquitetura. A Casa Estúdio para Diego Rivera e Frida Kahlo projetada por Juan O'Gorman entre 1931-1932 é símbolo desta época. Situada ao lado da primeira casa de O'Gorman, o conjunto é considerado um marco da modernidade arquitetônica mexicana.

7. Muitos destes edifícios ficaram com a estrutura comprometida por conta do forte terremoto que atingiu a cidade em setembro de 2017, e alguns até chegaram a desabar

8. Juan O'Gorman também era membro do movimento muralista, junto com Diego Rivera, José Clemente Orozco, David Alfaro Siqueiros. 
Dois volumes elevados do solo sob pilotis, um vermelho óxido e outro azul anil, conectados por uma passarela conformam de um lado a casa estúdio de Diego Rivera e do outro, a casa estúdio de Frida Kahlo. Com estrutura e instalações aparentes, os volumes contemplam grandes aberturas na fachada e terraços ajardinados na cobertura. Com telhado típico de fábricas permite a entrada de luz ao ateliê de Diego Rivera. Neste volume, a mesma solução da escada de concreto helicoidal exterior é utilizada. Além da aplicação de novas técnicas construtivas e simplicidade no uso dos materiais, Juan O'Gorman absorve as influências de Le Corbusier reinterpretando-as com um caráter próprio.

Em 1932, Juan O'Gorman vira professor da Escola Superior de Engenharia e Arquitetura do Instituto Politécnico Nacional, desempenhando um papel importantíssimo nas discussões e debates sobre o papel da arquitetura na sociedade. Fica responsável também, entre 1932-1935, pela construção de diversas escolas de ensino fundamental pela Secretaria de Educação Pública (SEP) com base de um plano socialista de escolas para toda a cidade. Através de um levantamento das instituições existentes, para a implantação dos novos edifícios, foram construídas vinte e três de ensino fundamental e uma técnica, localizadas nos centros urbanos e em zonas rurais sob o preceito de que deveriam ser econômicas, simples e higiênicas. Custando o menos possível, dentro do melhor funcionamento, foram desenvolvidas com uma tipologia " $T$ ". Onde programa principal das salas de aulas foi disposto no eixo horizontal do "T" e as circulações e serviços no eixo perpendicular. Com estrutura de concreto armado, pensadas através de módulos, para possíveis ampliações no futuro e com conforto térmico e iluminação natural, sistematizando o programa, a tipologia, racionalização do sistema construtivo e sua materialidade (LOBO, 2010, p. 90 e 91). Foram incluídos também murais de diversos pintores.

Neste mesmo ano, Carlos Obregón Santacilia lança um concurso público para o projeto e construção de moradia mínima para os trabalhadores de classe operária na Cidade do México através do "Ministério da Construção Moderna", no qual convoca engenheiros e arquitetos para proporem e analisarem as condições espaciais e técnicas para habitação mínima social. 0 projeto vencedor do arquiteto Juan Legarreta, em Balbuena, contemplava um conjunto de 120 casas agrupadas em quatro quadras e um jardim nomeado "Jardin Obrero". As habitações tinham três tipologias que variavam de 44 a 66 metros quadrados, nas quais as menores eram casas térreas e as maiores incluíam uma oficina ou um espaço comercial.

A resposta desses jovens arquitetos às demandas nacionais, para a educação e habitação, por exemplo, foram atendidas de modo significativo através do pensamento racionalista, atentos aos movimentos vanguardistas e rompendo com o passado. 


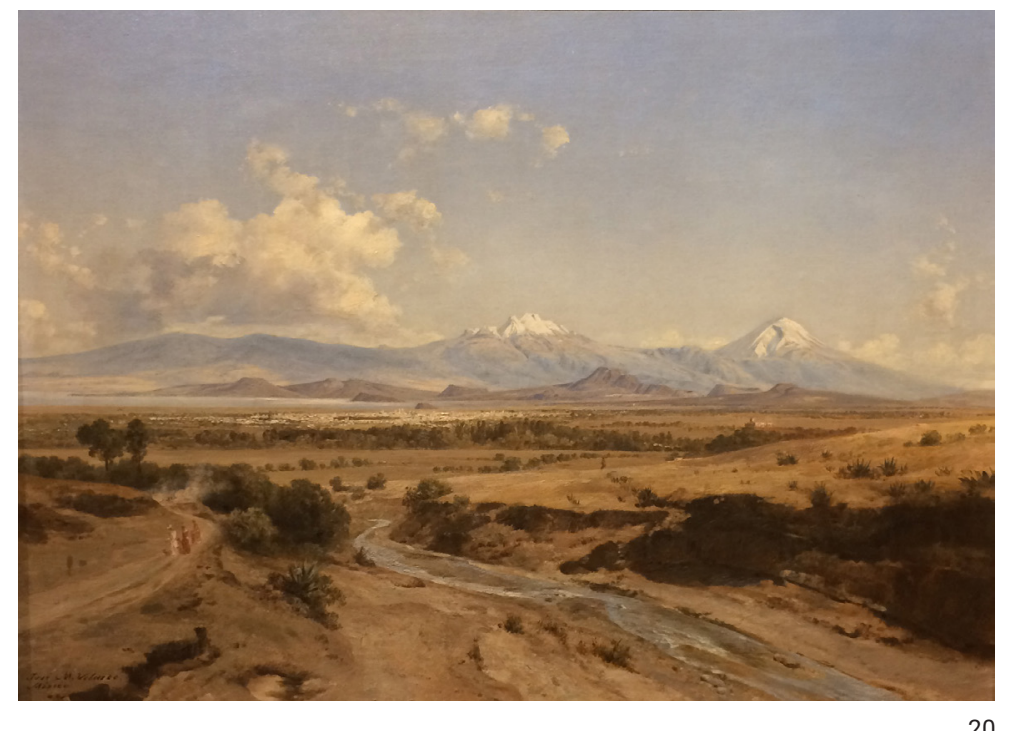



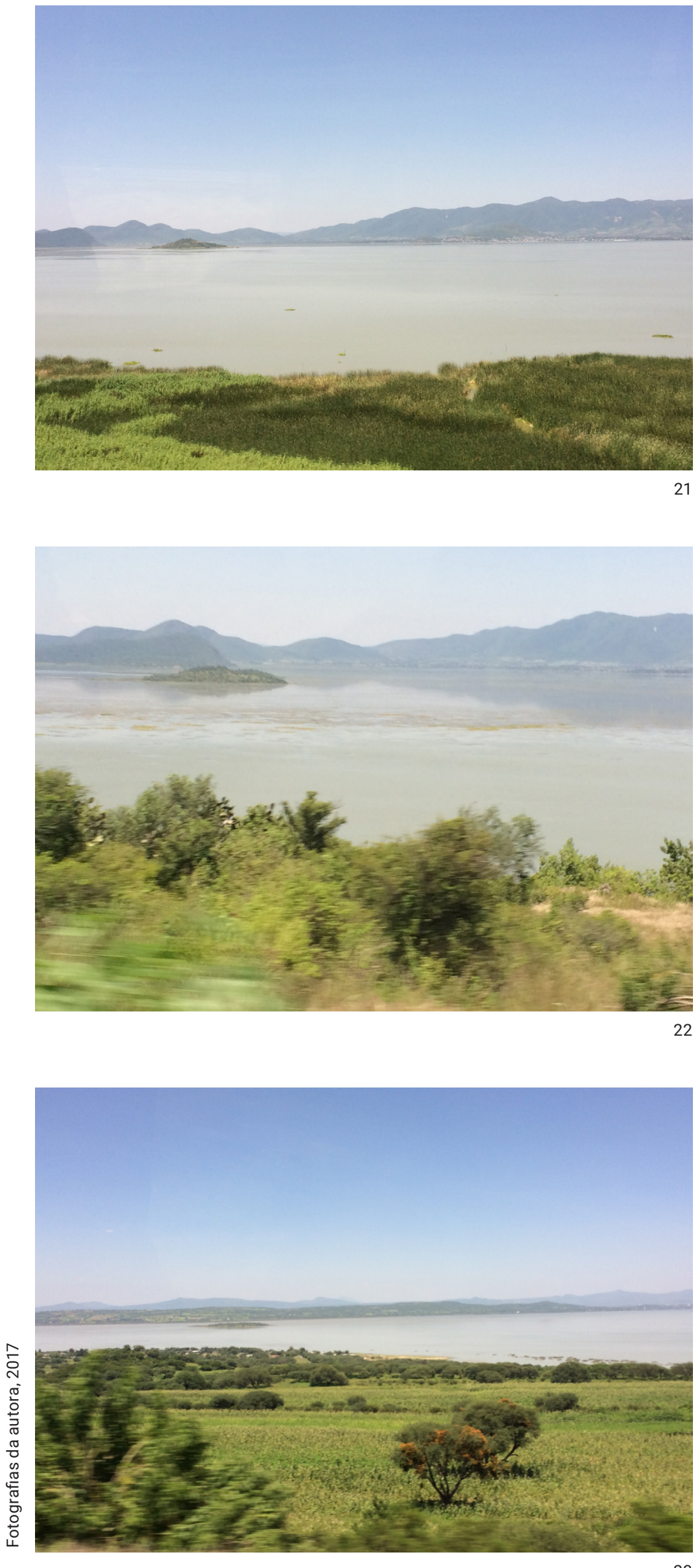
"Si queremos ser modernos hay que seguir la tradición de hacer arquitectura contemporánea”. (BARRAGÁN, 1938, p. 20)9

Com a industrialização, inicia-se uma intensa fase de construção na cidade, que neste momento passa por uma grande fase de crescimento econômico (CASTREJÓN, 1989, p. 73). Neste contexto, que incluía uma significativa reforma agrária no país, a família de Barragán perde algumas das propriedades rurais na região de Jalisco e Barragán decide mudar para a Cidade do México. Barragán aponta em alguns desenhos a sua preocupação com o crescimento da cidade sobre o Vale ${ }^{10}$. A partir das notícias que vêm de fora e pela oportunidade de ver de perto a arquitetura de vanguardas europeias, Barragán encontra a possibilidade de experimentar uma nova arquitetura, passando por uma fase de transformação.

Barragán abre um escritório na Cidade do México, e apesar de reconhecido como engenheiro, nas placas que colocava nos edifícios, identificava-se como "Luis Barragán, arquitecto" (CASTREJÓN, 1989, p. 73 e 74). Estas placas feitas com tipografias em ferro permanecem até os dias de hoje nas fachadas destes edifícios.

$\mathrm{O}$ arquiteto compra diversos terrenos no bairro de Cuauhtémoc, na Cidade do México, projetando e construindo uma série de edifícios habitacionais em áreas centrais da cidade associado ao arquiteto José Creixell (1908-2003). Neste período, Max Cetto (1903-1980) chega no México, saindo da Alemanha, e após passar pelos Estados Unidos, onde encontra seu amigo arquiteto Richard Neutra (1892-1970). Cetto, por problemas migratórios decide se mudar para o México e Barragán o contrata em seu escritório e para o convívio cotidiano com a cultura arquitetônica dos projetos habitacionais na Alemanha das décadas de 1920-1930 (RICALDE, 1989 , p. 122). Essas colaborações foram riquíssimas no processo da produção arquitetônica de Barragán explícitas em suas obras. Max Cetto colaborou no projeto do Edifício Casa Estúdio para Quatro Pintores na Plaza Melchor Ocampo, na Cidade do México, 1939-1940 e, posteriormente em casas do novo loteamento Jardines del Pedregal de San Ángel, 1945-1954, ao sul da Cidade do México.

Este conjunto de obras: Duas casas na Avenida México, 1936; Casa na rua Río Guadiana, 1936; Casas na avenida Mazatlán, 1936; Edifício de apartamentos na rua Estocolmo, 1937; Casa na avenida Nuevo León, 1938-1939; Conjunto de duas casas e um Edifício na rua Sullivan, 1939; Casa Estúdio Orozco, 1940; Edifícios na rua Río Mississippi, 1938-1940; Edifícios na rua Río Elba, 1940; Edifícios na praça Melchor Ocampo, 1939-1941; localizados entre outros edifícios nestes bairros centrais da Cidade do México, e por muito esquecidos na historiografia mexicana, representam uma fase importante do arquiteto. Fase na qual ele sai da província onde atende às demandas do mercado imobiliário da época, e aporta o valor arquitetônico a essa produção (MONTEYS, 1989, p. 108). Atualmente, muitas destas obras encontram-se descaracterizadas, algumas em péssimo estado de conservação, e outras sofreram drásticas reformas e mudanças de usos (algumas casas deste período viraram estabelecimentos comerciais descaracterizados de sua arquitetura original). Essa

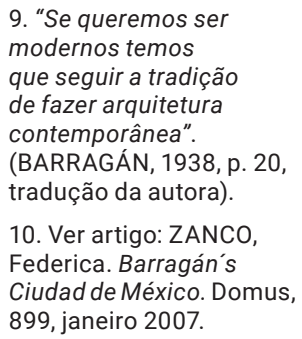


descaracterização resulta das circunstâncias em que ocorrem as preservações dos bens arquitetônicos no país. No México, o INBA (Instituto Nacional de Bellas Artes) não considera os edifícios construídos após 1900, então todo período que conforma o movimento moderno no México depende para a sua preservação da decisão de seus atuais proprietários, ou seja, cabe aos donos desses edifícios decidirem sobre a sua preservação.

Neste conjunto de obras, é possível identificar características do pensamento moderno apropriadas como terraços-jardim e fachadas livres com caixilharia em ferro, por exemplo. Barragán fazia o uso recorrente dos mesmos elementos arquitetônicos, e às vezes, até a mesma solução espacial (Casa na rua Río Guadiana, 1936 e uma das casas do conjunto de construções rua Sullivan, 1939, mantêm a mesma planta e a mesma fachada, porém espelhadas). Os volumes dessas obras ocupam toda a área do lote permitida para construção, na maioria das vezes com janelas horizontais e em alguns casos com balcões. As coberturas são terraços-jardim, com uma viga de borda fazendo o arremate do espaço e o enquadramento da vista para a cidade. Nos edifícios, alguns dos térreos são de uso comercial, atendendo ao uso misto e às dinâmicas da cidade em crescimento. $O$ uso da cor não era relevante neste período, mas o jogo de luz natural interna sim. Sua arquitetura se conformava neste período por volumes brancos com grandes aberturas na fachada.

Na Praça Melchor Ocampo configura-se um interessantíssimo conjunto arquitetônico conformado por uma série de edifícios projetados pelos arquitetos Enrique de Moral, Augusto H. Álvarez (1933-1995) e Juan Sordo Madaleno (1916-1985). Barragán projeta três edifícios nesta praça, sendo um deles em parceria com Max Cetto (1903-1980), o Edifício Casa Estúdio para Quatro Pintores.

E se essa produção escapa dos critérios do conjunto de obras de Barragán, não escapa por outro lado de aspectos gerais do movimento moderno. Miquel Adrià, em seu livro de 2016, La sombra del Cuervo - arquitectos mexicanos tras la senda de Le Corbusier, discute exatamente o impacto de Le Corbusier, que nunca conheceu o México, teve nos arquitetos dessa geração. É perceptível que o pensamento e obra do arquiteto franco-suíço influenciaram os arquitetos Juan O'Gorman, Luis Barragán, Mario Pani (1911-1993), Juan Sordo Madaleno, Augusto H. Álvarez, Pedro Ramírez Vázquez (1919-2013) e Teodoro González de León (1926-2016).

Curioso notar, que este conjunto de obras, que apesar de apresentarem um momento chave de transição da produção de Barragán, não foi incluído nem na grande exposição sobre a obra de Luis Barragán no Museu Rufino Tamayo em 1985 ou nos catálogos feitos pelos fotógrafos Armando Salas Portugal (19161995) e Yutaka Saito (1945). 


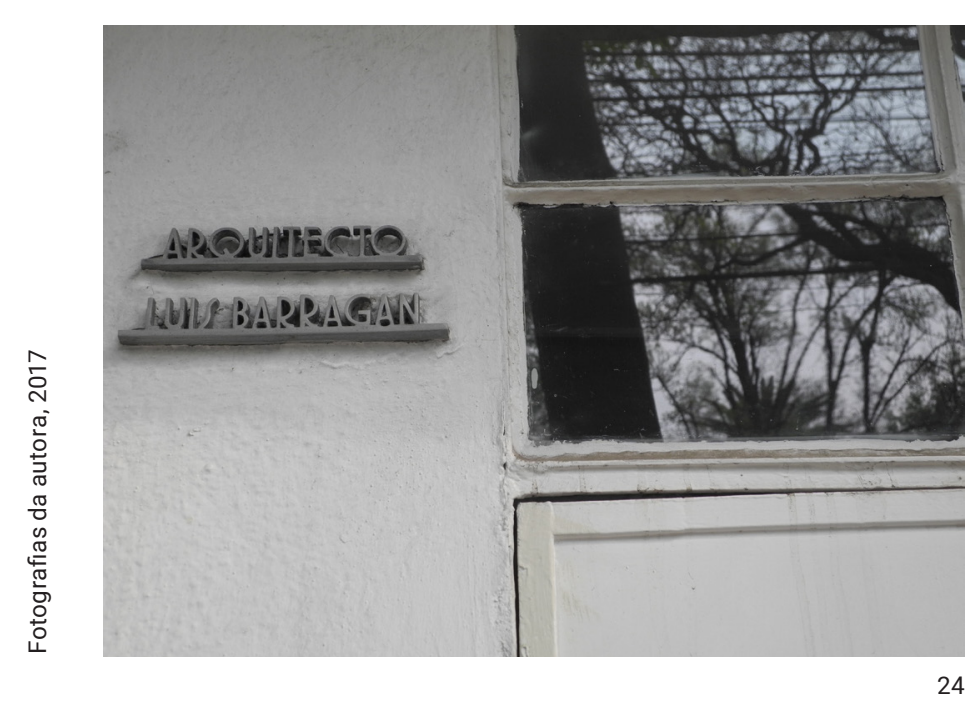

Placa de identificação. Duas Casas Av. México, 2017

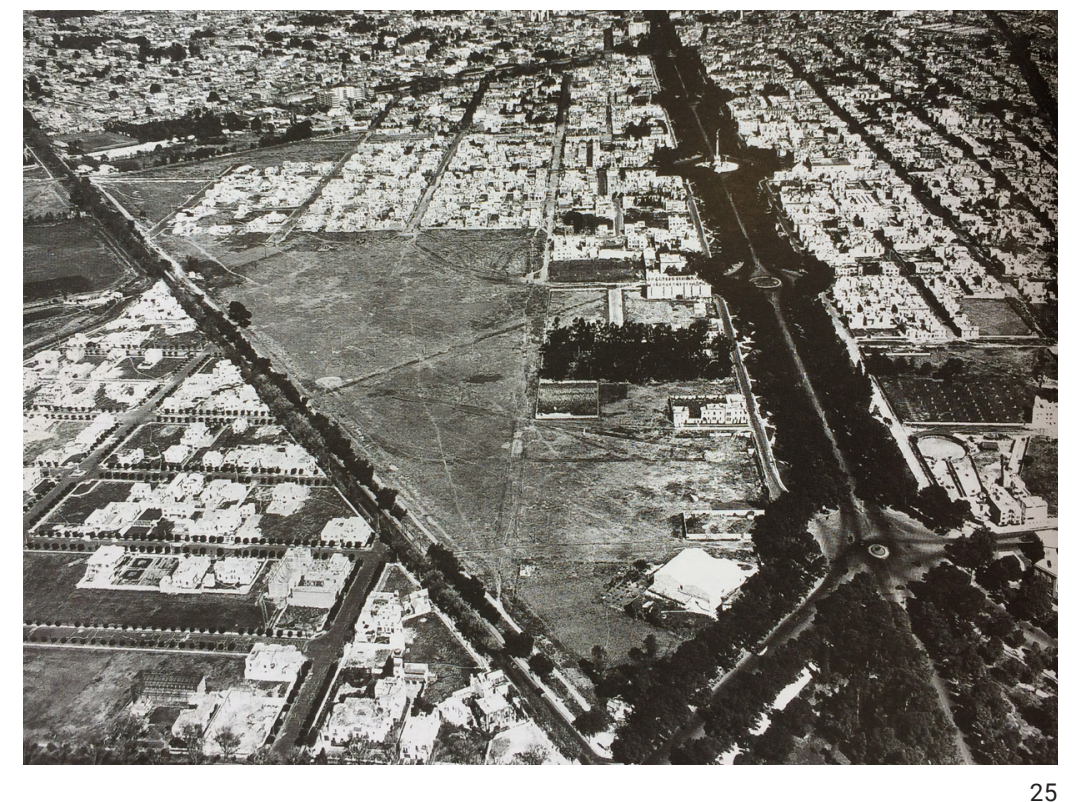



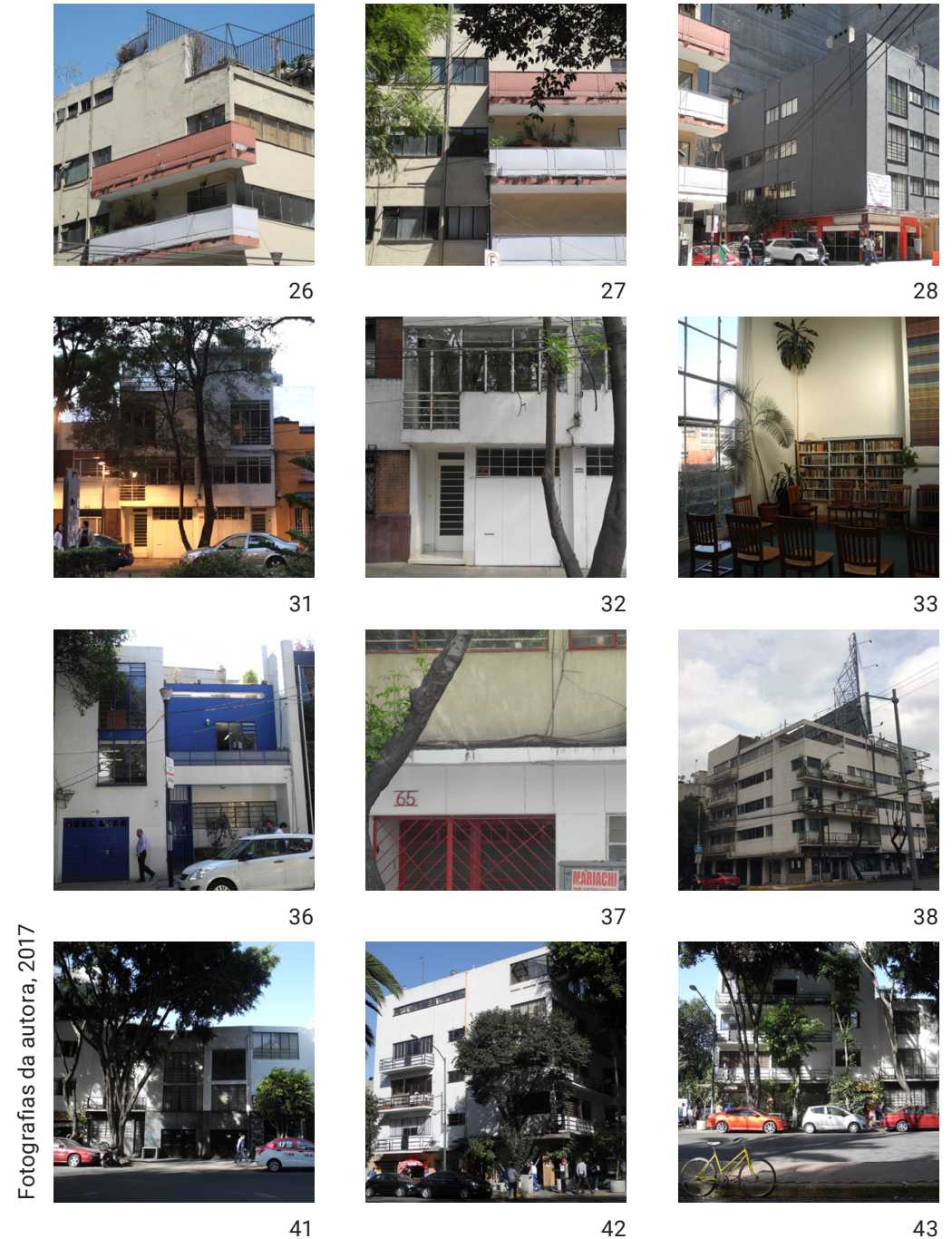

27

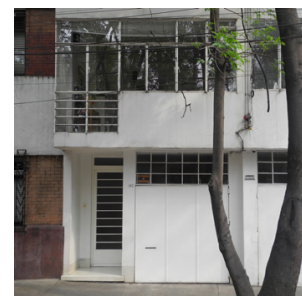

32

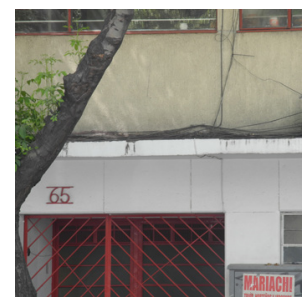

37

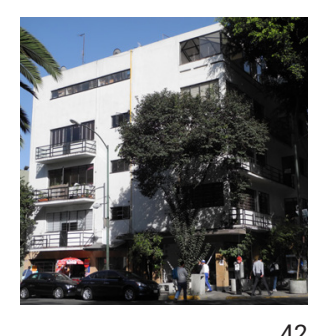

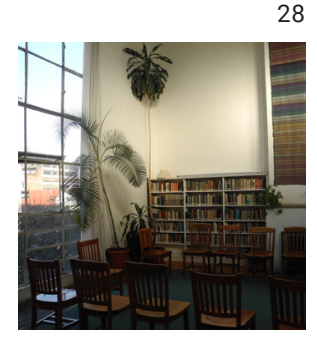

33
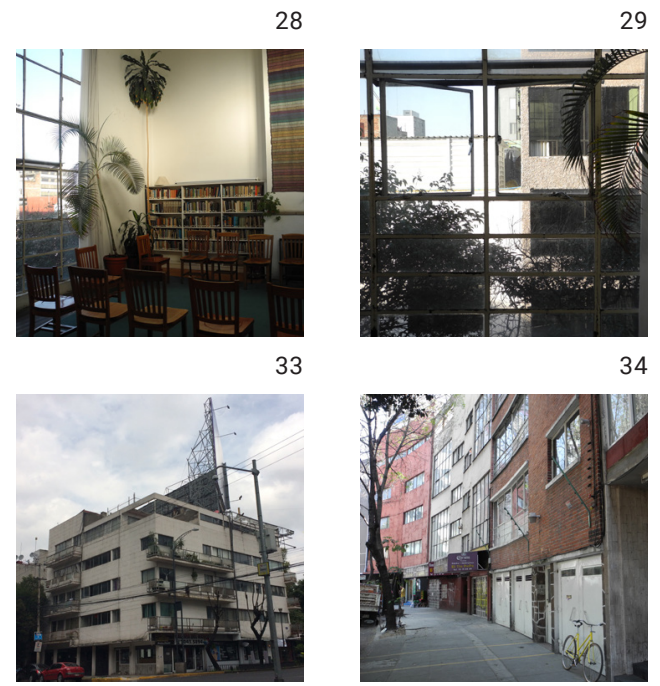

39
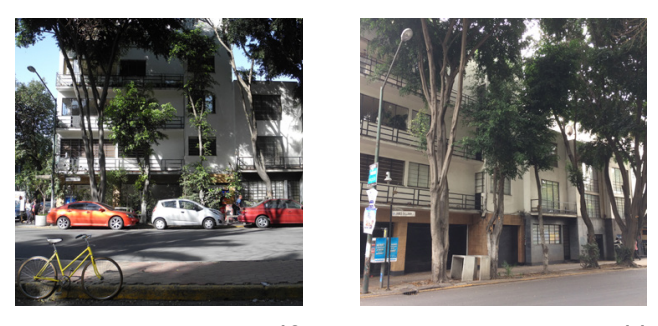
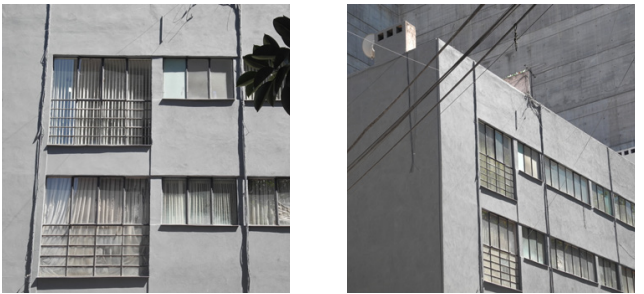

30

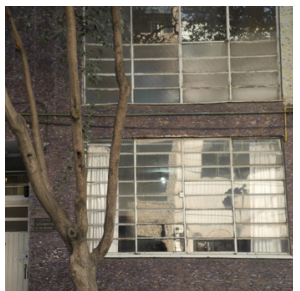

35

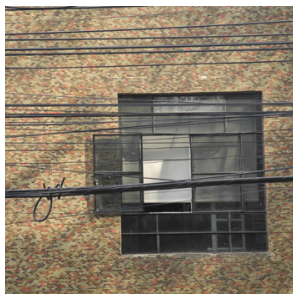

40

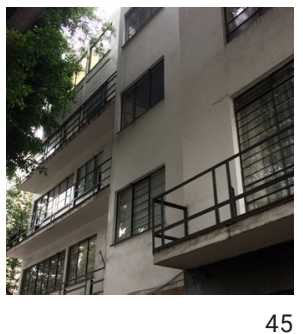




\subsection{Edifício Casa Estúdio para 4 pintores}

Em colaboração com o arquiteto de origem alemã Max Cetto, entre 1939-1940, Barragán realiza na praça Melchor Ocampo, no número 38, um edifício de apartamentos e estúdios para artistas, realizado para Carmen e Paz Orozco, no bairro Cuauhtémoc. Nesta mesma quadra, que antigamente estava conformada uma glorieta em frente, há nos números 56 e 64 dois edifícios projetados e construídos por Enrique de Moral, e no número 50 um edifício de Juan Sordo Madaleno em parceria com Augusto H. Álvarez (ZANCO, 2010, p. 90). Por conta das obras viárias para a realização do Circuito Interior (uma via elevada para autos ao redor da cidade) em 1961, essa glorieta sofre grandes transformações na paisagem e em seu entorno pelos acessos e alças à via elevada. A glorieta resulta atualmente então em uma sobra de área pública entre o eixo viário.

O volume do edifício para os quatro pintores acompanha a própria curvatura do terreno, e a proposta dos arquitetos contempla quatro apartamentos duplex, explorando o pé direito duplo e as grandes janelas piso teto. As quatro unidades habitacionais foram colocadas entre pares com uma escada central conformando a circulação vertical. As plantas são assimétricas e acompanham o desenho irregular do lote. $\mathrm{O}$ acesso aos mezaninos se dá um por uma escada helicoidal. $\mathrm{Na}$ cobertura há um terraço-jardim, e na fachada uma abertura horizontal arrematando a construção (ZANCO, 2010, p. 91). Após anos de abandono, um proprietário estrangeiro compra o edifício inteiro e se encarrega das obras de restauração do edifício ${ }^{11}$. Atualmente este edifício encontra-se em excelente estado de preservação, e a reforma respeitou ao máximo seu desenho original.

É possível identificar neste conjunto de obras da segunda fase a recorrência dos seguintes procedimentos: o desenho da luz e traços de Le Corbusier nos projetos de Luis Barragán.

11. O projeto de restauro do edifício é de autoria do jovem escritório mexicano de arquitetura Vrtical, e a obra foi recém terminada em 2017.

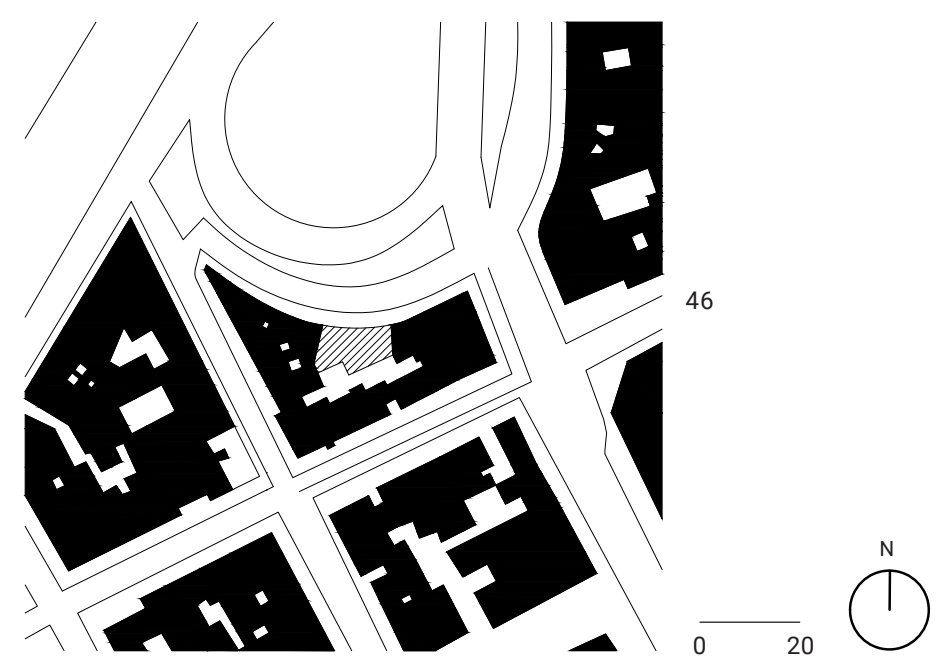




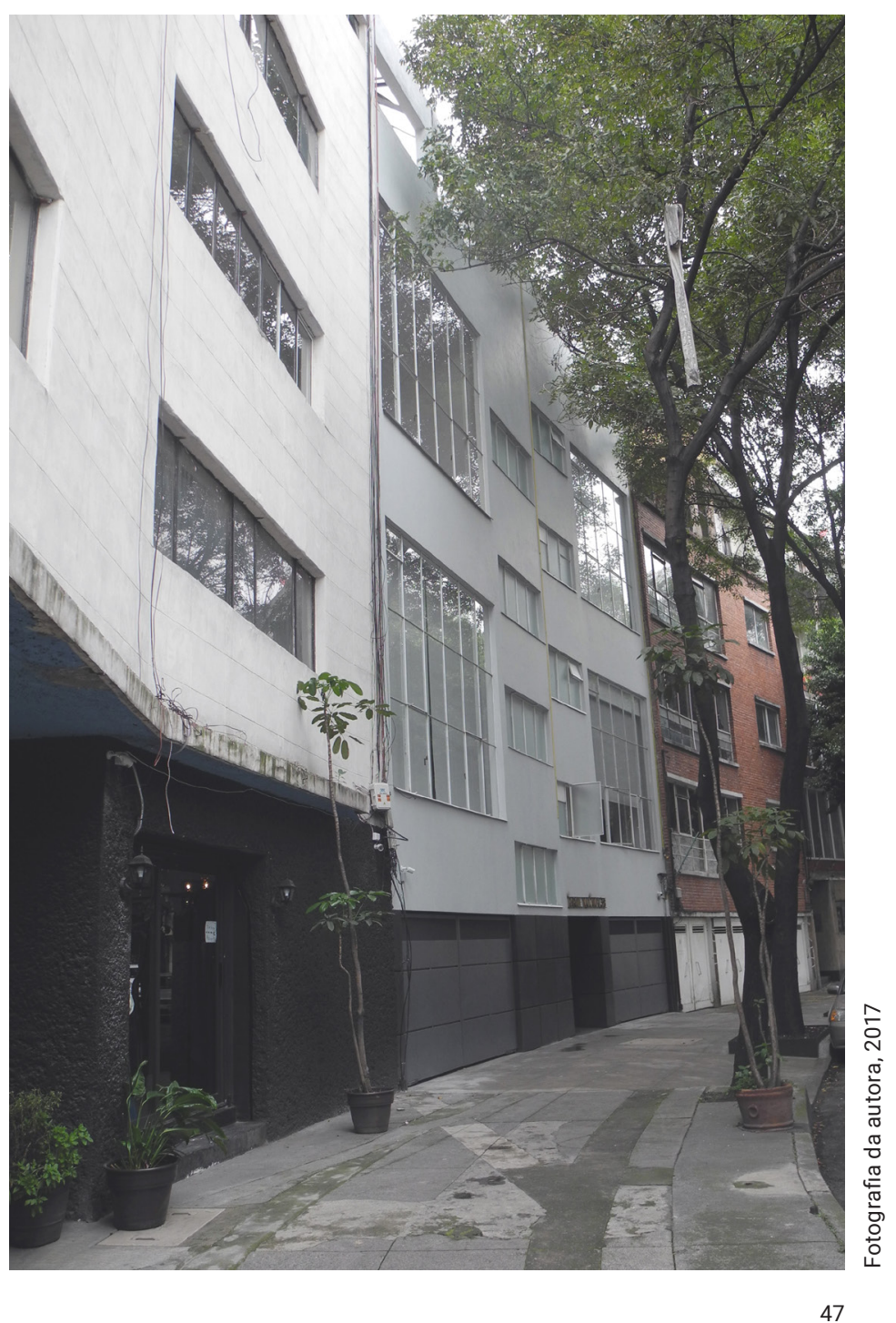

47 


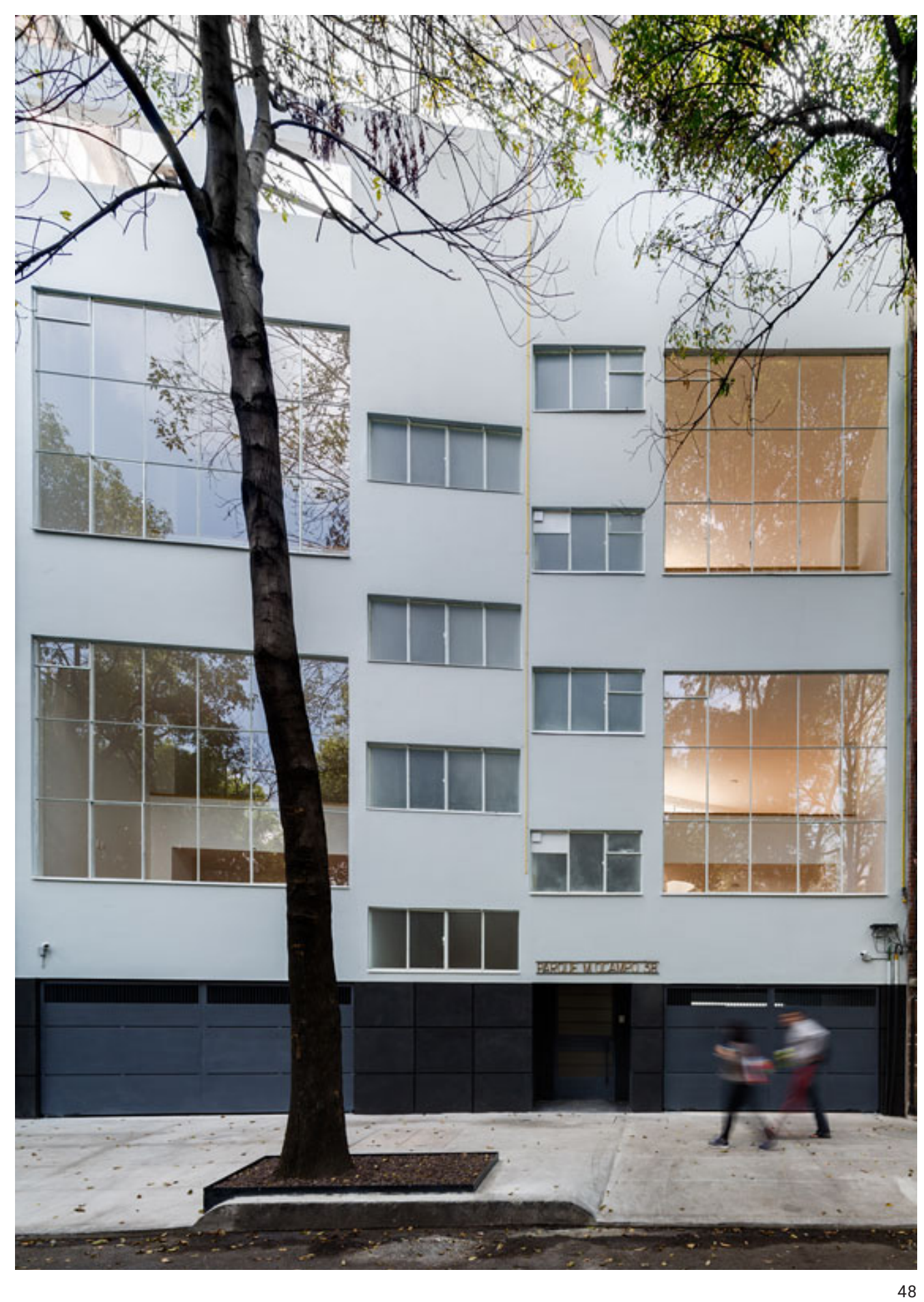




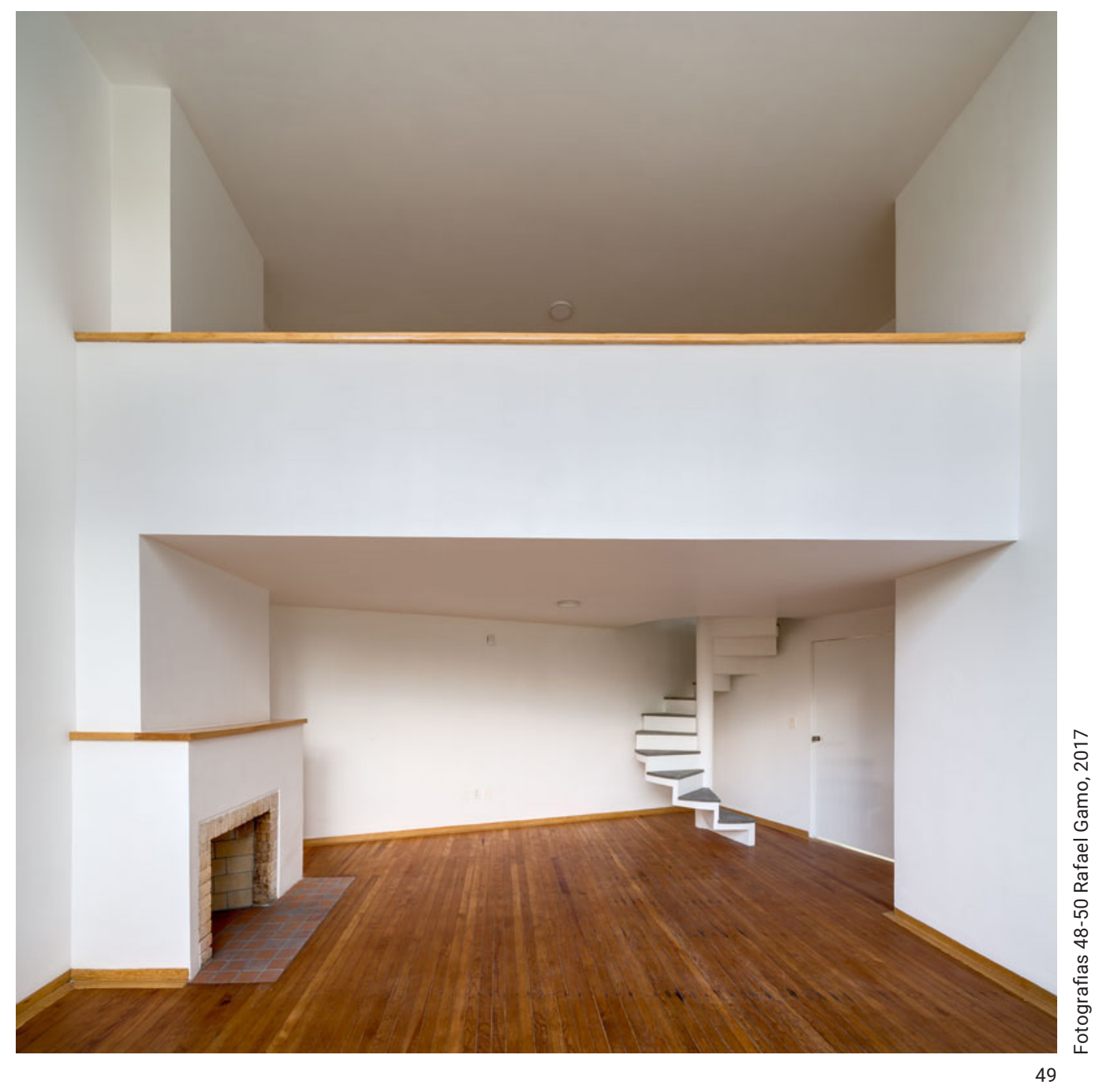



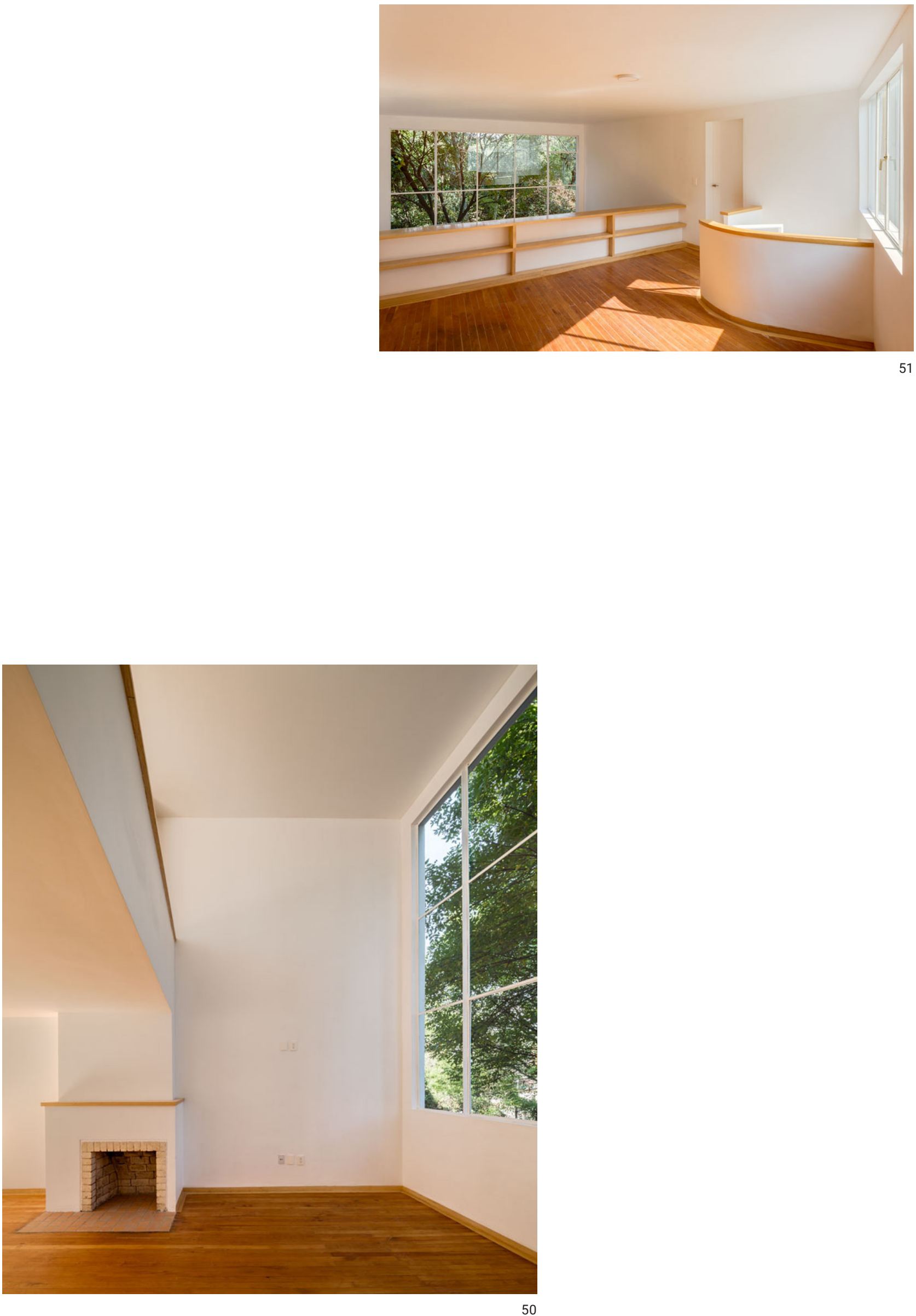


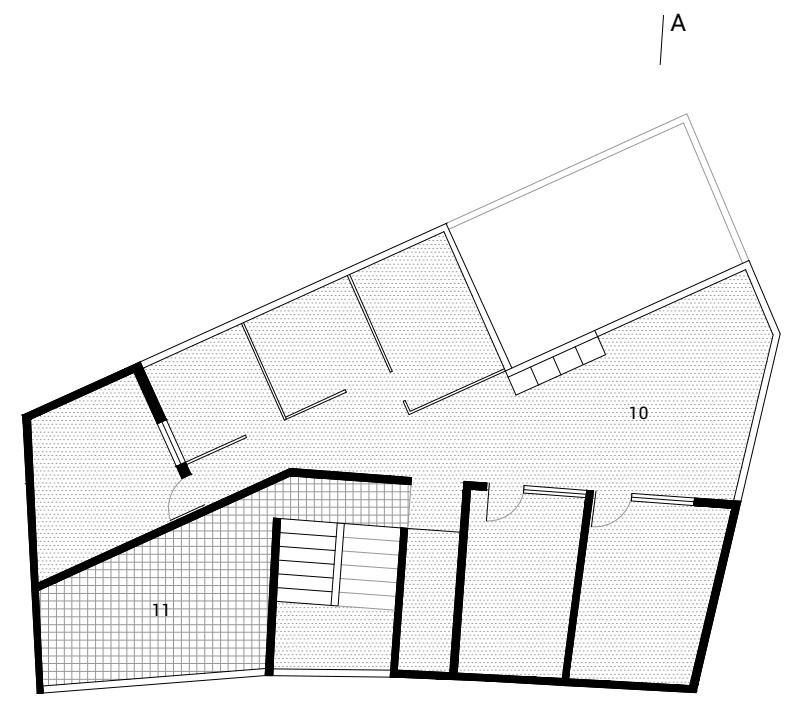

planta cobertura

A

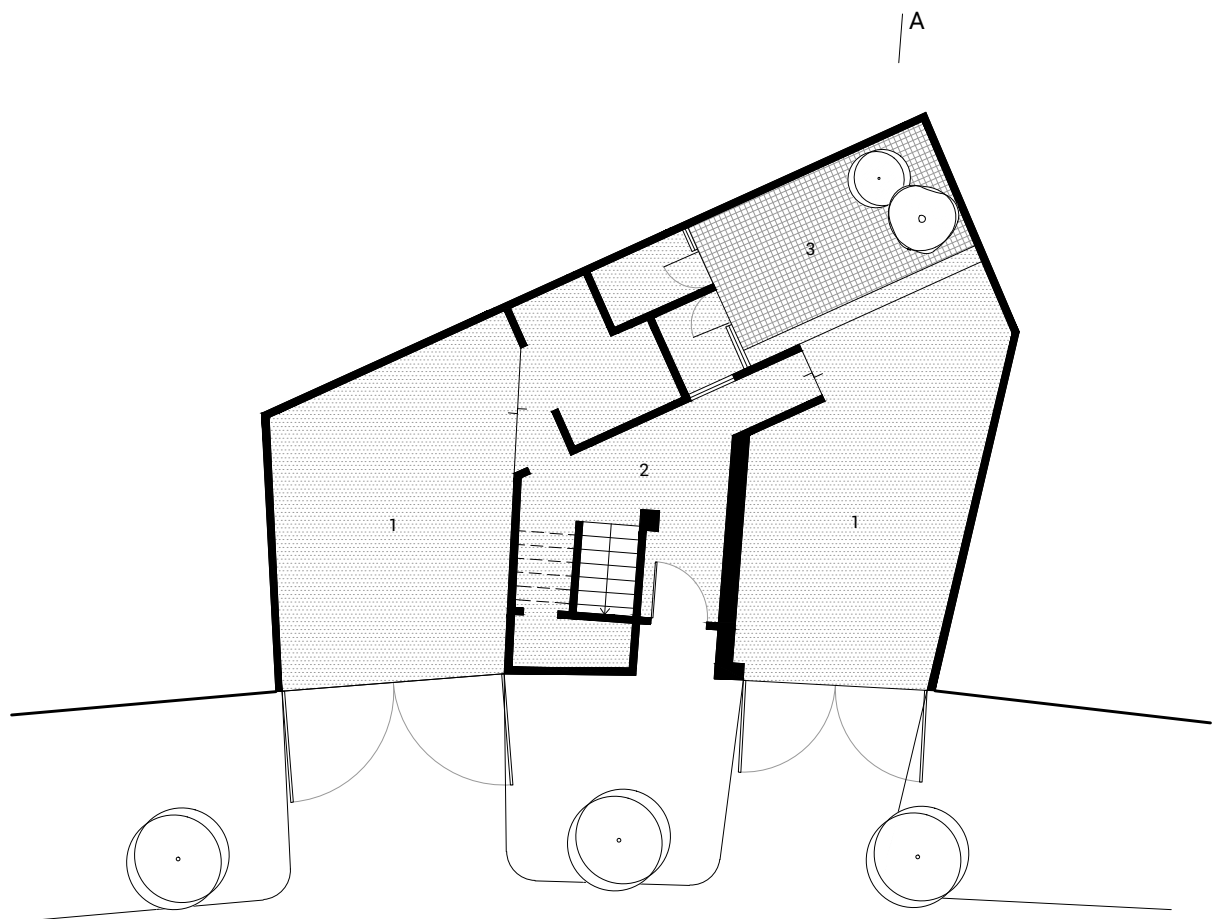

Rua Melchor Ocampo

planta térreo
1. garagem

2. vestíbulo

3. pátio

4. hall

5. sala / estúdio

6. cozinha

7. dormitório / mezanino

8. closet

9. banho

10. lavanderia

11. terraço jardim

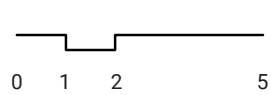





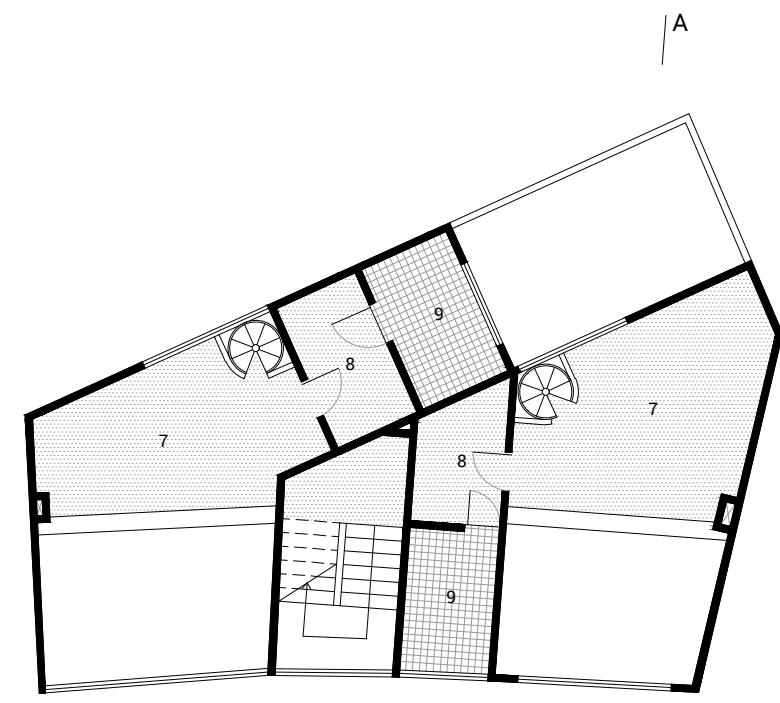

planta tipo superior
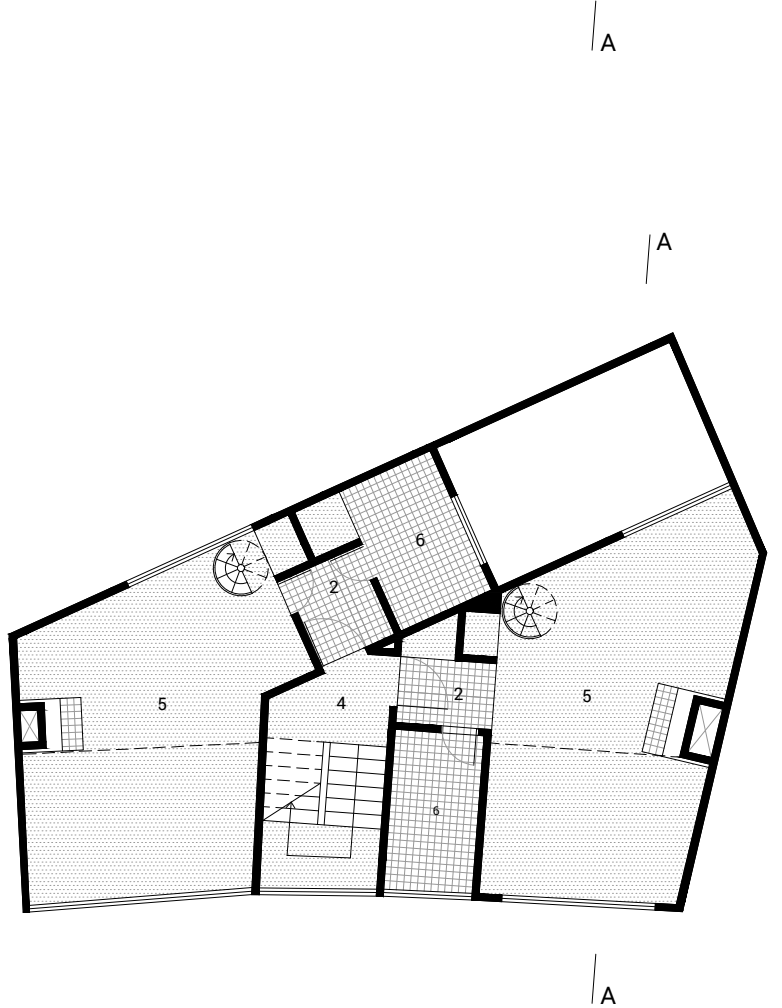

planta tipo inferior

1. garagem

2. vestíbulo

3. pátio

4. hall

5. sala / estúdio

6. cozinha

7. dormitório / mezanino

8. closet

9. banho

10. lavanderia

11. terraço jardim

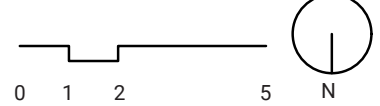





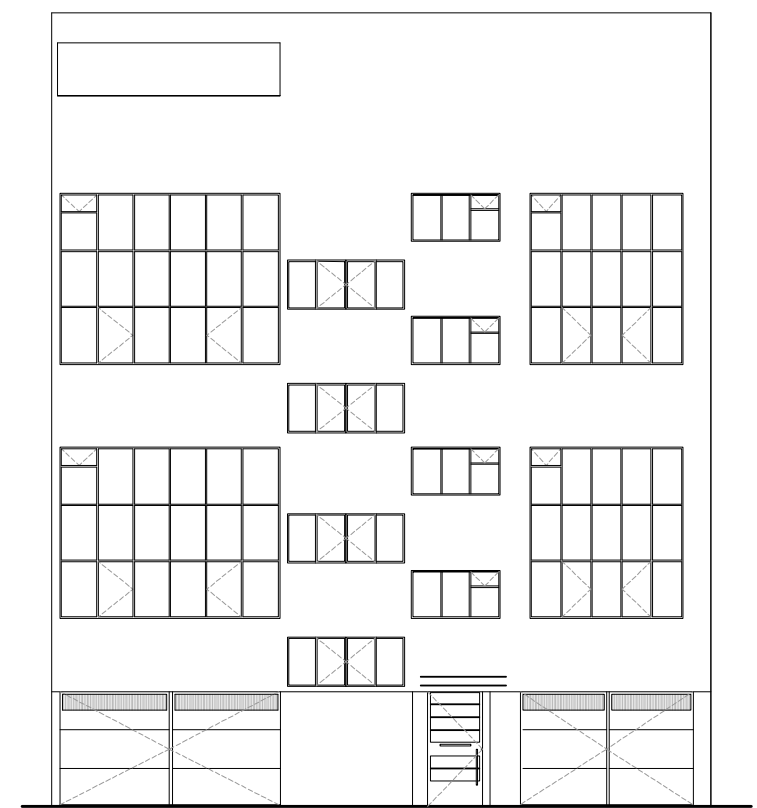

fachada norte

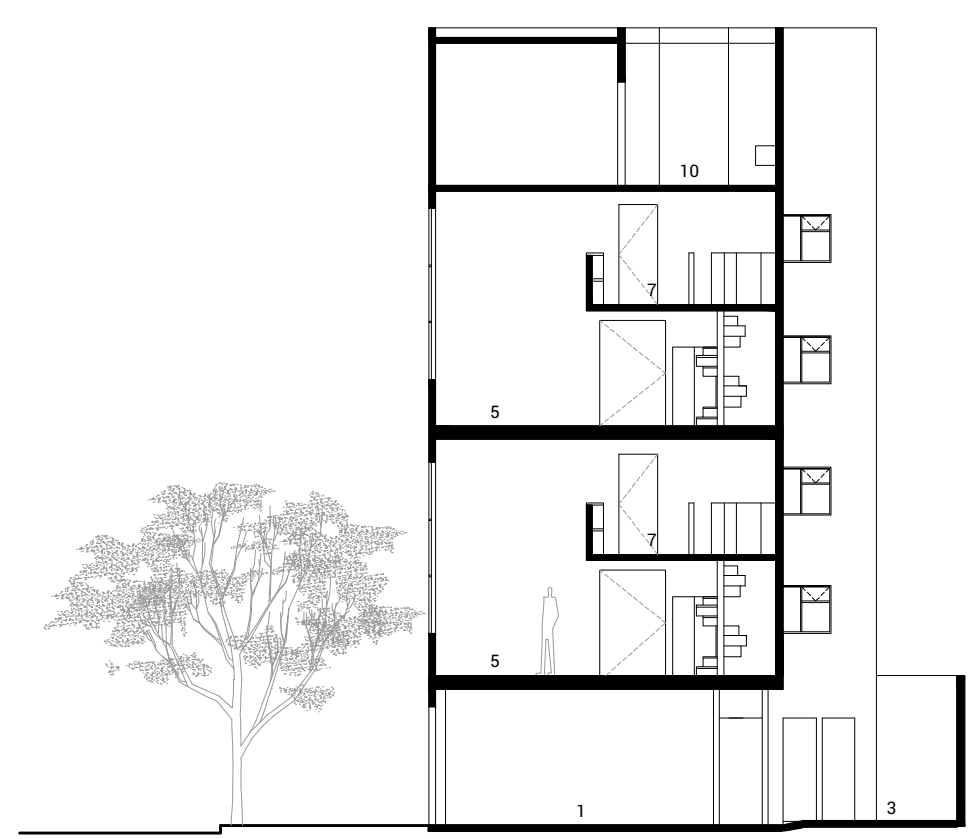

corte A
1. garagem

2. vestíbulo

3. pátio

4. hall

5. sala / estúdio

6. cozinha

7. dormitório / mezanino

8. closet

9. banho

10. lavanderia

11. terraço jardim

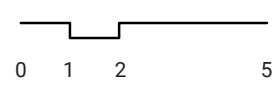




3. Terceira fase a partir de 1945 
La nostalgia. Es consciencia del pasado, pero elevada a potencia poética, y como para el artista su pasado personal es la fuente de donde emanan sus posibilidades creativas, la nostalgia es el camino para que ese pasado rinda los frutos de que está preñado. (BARRAGÁN, 1980, p. 61) ${ }^{1}$

\subsection{Contexto histórico anos 1940 e 1950 no México}

As décadas de 1940 e 1950 no México foram marcadas por uma série de transformações políticas e ideológicas. A consolidação da economia deu-se através de medidas políticas que proporcionaram a abertura de investimentos estrangeiros para a industrialização (ANDA, 1995, p. 190). Se de um lado o Governo propunha diversos programas a nível nacional de implementação de escolas, hospitais, habitação coletiva, por outro, a iniciativa privada tinha carta branca para investir e construir nas cidades. Sobre a produção de um território comum entre a arquitetura e o Estado, Adrián Gorelik define:

1. "A nostalgia. É consciência do passado, porém elevada à potência poética, e como para o artista seu passado pessoal é a fonte de onde emanam suas possibilidades criativas, a nostalgia é o caminho para que esse passado renda os frutos do que está carregado". (BARRAGÁN 1980, p. 61, tradução da autora).

O trabalho profissional nos escritórios públicos de gestão com programas avançados gerados pela burocracia estatal, assentando uma tradição de arquitetura pública altamente qualificada que se consolidará nos programas de planificação nacional nos anos quarenta e cinquenta. (GORELIK, 2005, p. 33)

A nacionalização do petróleo, o crescimento da indústria e um programa progressista de construção do país deram aos arquitetos a importância e reconhecimento ao melhoramento da vida pública (CANALES, 2013, p. 69). 0 programa federal de construção de escolas (CAPFCE) de 1942 foi liderado por Villagrán, José Luis Cuevas, Mario Pani e Enrique Yánez. Os primeiros conjuntos habitacionais em larga escala foram feitos por Mario Pani, fazendo com que os anos 1940 e 1950 ficassem marcados pelo período da chamada arquitetura heroica. Como menciona a arquiteta e pesquisadora mexicana Fernanda Canales em sua tese de doutorado apresentada no programa de Pós-Graduação da Escola Técnica Superior de Arquitetura de Madri da Universidade Politécnica de Madri em 2013, que "A riqueza do intercâmbio cultural trouxe para arquitetura mexicana definições e possibilidades inéditas". Com a Segunda Guerra Mundial, muitos estrangeiros 
chegaram ao México nesta época: Félix Candela (1910-1997), Clara Porset (18951981), José Luis Benlliure (1898-1981), Vladimir Kaspé (1910-1996), Hannes Meyer (1889-1954), Mathias Goeritz (1915-1990), entre outros. Luis Barragán estabeleceu relação profissional e pessoal com alguns deles. Com Clara Porset, por exemplo, desenharam juntos os mobiliários para os projetos residenciais. Clara, de origem cubana e com formação acadêmica relacionada às artes e desenho industrial nos Estados Unidos, França e Alemanha, escolheu o México para viver. Foi docente e colaborou também com os arquitetos Juan Sordo Madaleno, Enrique Yánez, Mario Pani e Max Cetto. Escreveu diversos artigos e em 1952 logrou a exposição "El arte en la vida diária" no Palácio de Bellas Artes, e depois na recém Cidade Universitária, integrando o artesanato mexicano com objetos industriais de uso cotidiano (FLORES, 2002, p. 25 e 26). Clara Porset foi uma das principais desenhadoras de mobiliário mexicano.

Ao longo de sua trajetória, Luis Barragán teve diversos outros interlocutores que the renderam boas parcerias. Dentre eles, se destacam: Jesús "Chucho" Reyes (18801977) e Mathias Goeritz (1915-1990).

Mathias Goeritiz chega ao porto de Veracruz em 1949. Recebido por Ida Rodríguez (1925-2017), com destino à Guadalajara, passando pela Cidade do México. Através de Ida, (neste momento esposa de Edmundo O'Gorman), Mathias Goeritz conhece Luis Barragán e Jesús "Chucho" Reyes. Além de sua prática artística, Mathias manteve intensas atividades culturais. Na faculdade propunha métodos e práticas da Bauhaus desenvolvidas por Johannes Itten e Moholy-Nagy (GARCÍA, 2014, p. 46), e promoveu exposições em diversas galerias de arte, tanto em Guadalajara quanto na Cidade do México. "Nestes anos, Goeritz colaborou com duas personalidades significativas da arte e arquitetura mexicanas: Jesús Reyes Ferreria e Luis Barragán" (GARCÍA, 2014, p. 49). Luis Barragán encomendou a primeira escultura urbana de Mathias Goeritz para a entrada do loteamento que estava desenhando e empreendendo, em 1951, Jardines del Pedregal, ao sul da Cidade do México. A escultura em concreto armado "El animal del Pedregal" localizada na Plaza de las Fuentes, anuncia a entrada ao bairro. A escultura da serpente na entrada ao loteamento remete simbolicamente aos animais ancestrais da cultura mexicana. Mathias Goeritz realizou pinturas, esculturas, murais, vitrais, torres escultóricas, tipografias e arquitetura. Barragán fazia uso dos quadros revestidos em folha de ouro de Mathias Goeritiz em suas obras, sempre posicionados de modo estratégico dentro dos ambientes. Os tons amarelados, o dourado constante na obra de Luis Barragán são evidências próximas de Barragán e Goertiz. As Torres Satélite, 1957-1958, uma das obras mais emblemáticas deste período, com autoria de Luis Barragán e Mathias Goeritz e consultoria estética de Jesús "Chucho" Reyes. As cinco torres de concreto (no projeto original eram sete), com plantas triangulares que variam de 30 a 52 metros, anunciam a cidade em expansão carregam um forte valor simbólico e são marcos na paisagem. Luis Barragán faz referência às torres de San Gimignano, na Itália, e posteriormente Mathias Goeritz realiza uma série de esculturas urbanas conformadas por torres.

Também nascido em Guadalajara, o pintor Jesús "Chucho" Reyes foi um dos maiores representantes da arte mexicana do século XX e segundo o poeta Carlos 
Reyes. Sua obra pode ser considerada paradigma dentro da busca de expressão plástica com inspiração local. A fonte de sua obra vem a partir da cultura popular e da vida cotidiana, constrói seu imaginário de cores e traduz o espírito da época. Apropria-se das cores dos mercados de frutas e flores, dos altares, das festas típicas populares. Barragán e "Chucho" Reyes se conhecem em meados dos anos 1940 e estabelecem uma forte relação de amizade e colaboração profissional:

Cuando pongo algún color fuerte, como el rojo o el morado, es porque de repente estalla en mi mente el recuerdo de alguna fiesta mexicana, algún puesto en algún mercado, la brillantez de alguna fruta, de una sandía, de un caballito de madera. En esto me parezco a Chucho Reyes Ferreira, que recordaba el amarillo como el de los pisos lavados con lejía y lo trasladaba al papel de china. (BARRAGÁN, 1976, p. 116)²

"Chucho" e Barragán têm mútua influência, em muito assemelham-se os ambientes da casa e ateliê do pintor com a casa e ateliê do arquiteto. Atmosfera âmbar, os vidros pintados de amarelo, as esferas de vidro, os objetos da cultura popular, as cerâmicas de Jalisco, Puebla, Michoacán e as figuras religiosas.

Em meados da década de 1940, a Escuela Nacional de Arquitectura lança um concurso interno entre professores e estudantes para a realização da Cidade Universitária localizada ao sul da cidade, em uma área denominada Pedregal. Inaugurada em 1952, a UNAM (Universidad Nacional Autónoma de México) conforma um dos conjuntos arquitetônicos mais significativos e expressivos da história da arquitetura moderna no México, e no limite, da América Latina. Enrique de Moral e Mario Pani ficaram encarregados pelo plano urbano, pela torre da reitoria e pela coordenação de todo o conjunto do qual 60 arquitetos, organizados em equipes três, ficaram responsáveis pelos projetos dos edifícios, entre os representantes estavam: Augusto H. Álvarez pelo edifício da Faculdade de Letras; José Villagrán pela Escola de Arquitetura (atualmente Faculdade de Arquitetura e Urbanismo); Félix Candela pelo Pavilhão de Raios Cósmicos; Juan O'Gorman pelos murais da Biblioteca Central; Pedro Ramírez Vázques (1919-2013) pela Faculdade de Medicina; Enrique Yánez pela Faculdade de Ciências Químicas, Enrique de la Mora (1907-1978) pelo conjunto de edifícios das Humanidades; Alberto Arai (1915-1959) pelo conjunto desportivo (frontones), Augusto Pérez Palacios (1909-2002) pelo estádio olímpico, Luis Barragán como engenheiro responsável pelas áreas ajardinadas; entre outros, resultando em um verdadeiro laboratório de experimentações. Os muralistas David Alfaro Siqueiros, Diego Rivera e Carlos Mérida (1891-1984) realizaram murais representativos, metafóricos e simbólicos fazendo parte da composição dos edifícios (ADRIÀ, 2016, p. 26), conformando a integração plástica entre arte e arquitetura. 


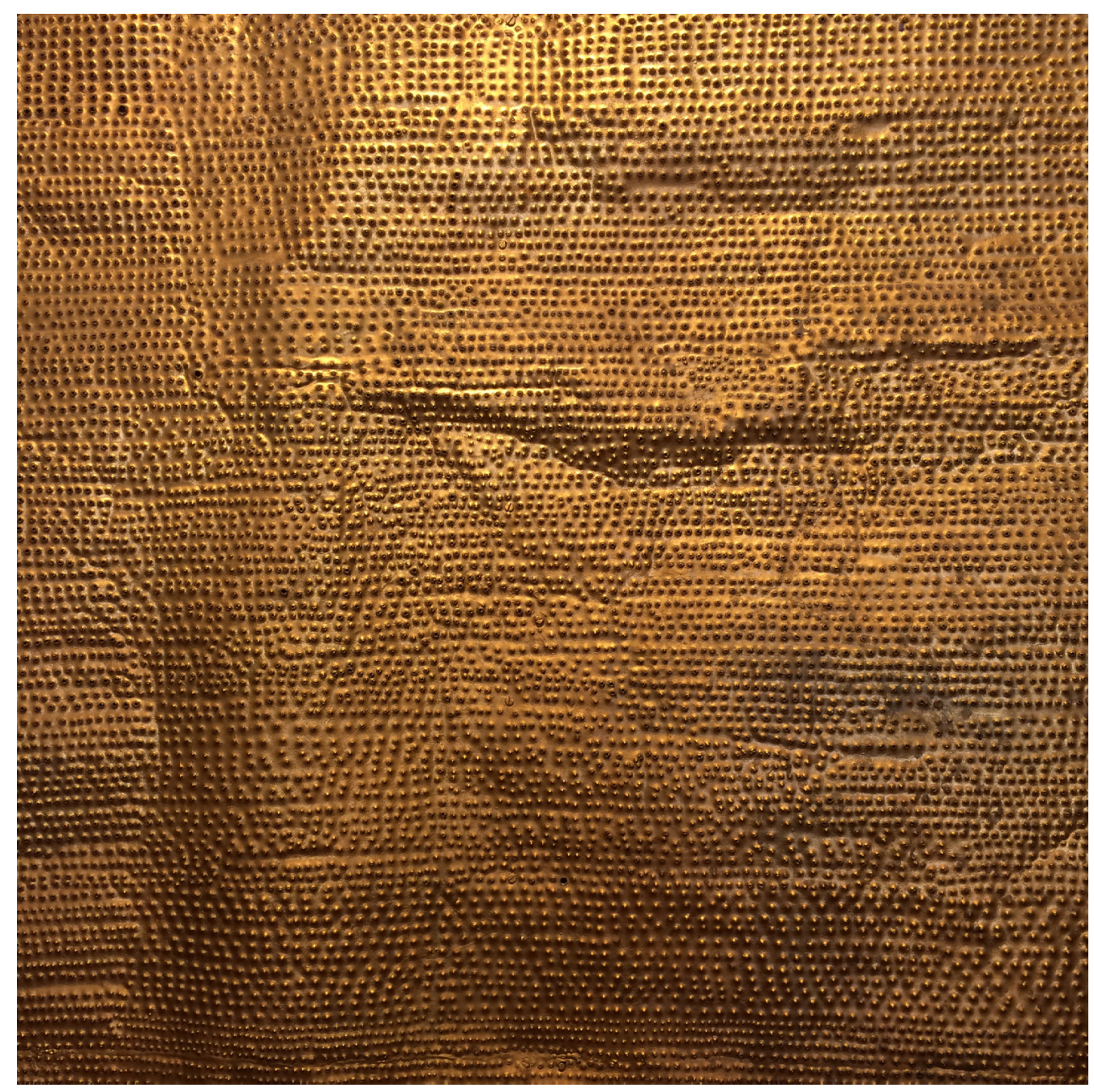

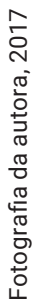

Mensagem em folha de ouro, Mathias Goeritz, 1967-1968 


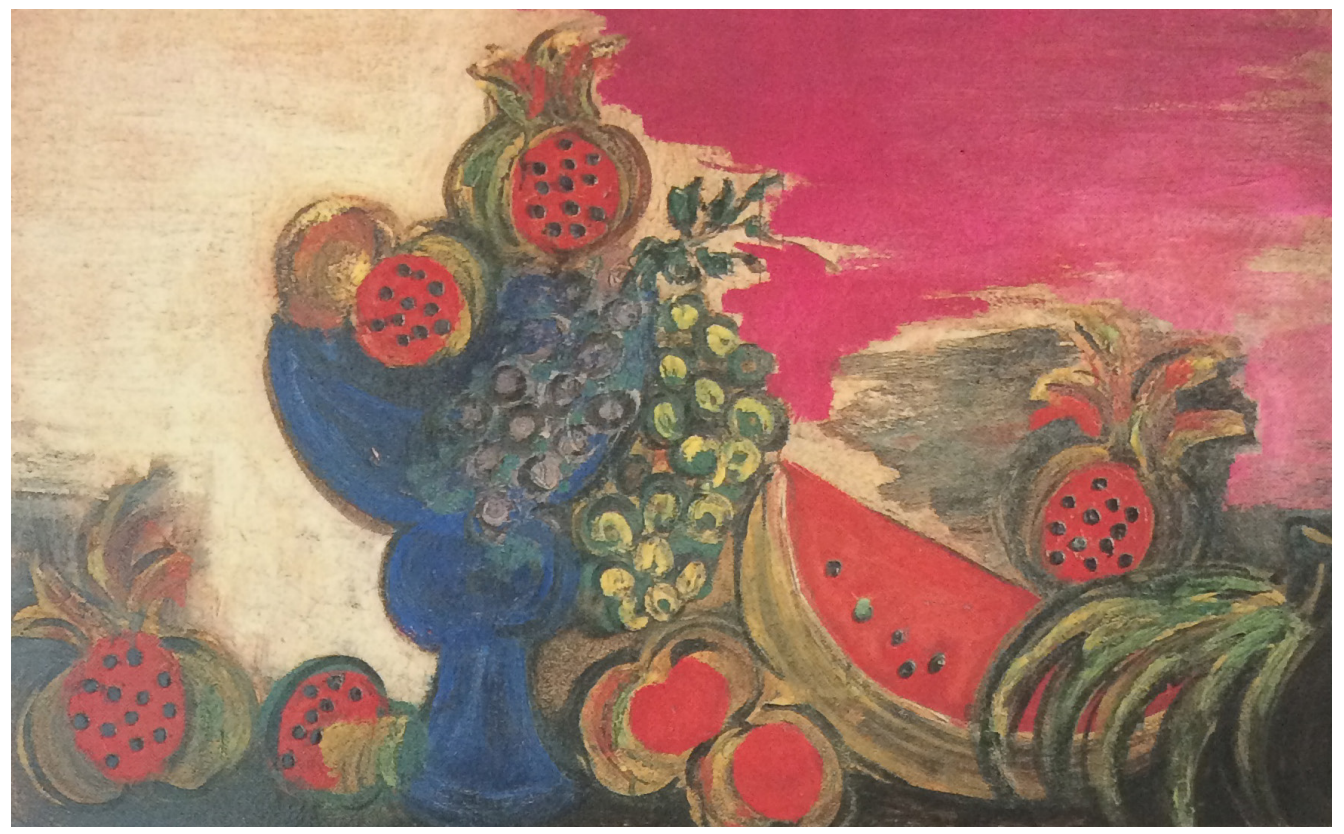


Al sur del campus se situaron las escuelas técnicas, al norte las humanidades, en el eje del conjunto se localizó a la Rectoría, frente a ésta la Torre de Ciencias y en la periferia, los edificios para deporte y habitación al mismo tiempo separados y ligados al conjunto por un novedoso sistema vial perimetral. Efectivamente, en la Ciudad Universitaria se aplicó por primera vez un sistema de circulaciones continuas sin cruces que rodea a todo el conjunto. (GARAY, 2004, p.57) ${ }^{3}$

O conjunto contempla uma arquitetura inovadora integrada aos murais com térreos livres, pilotis, predominância de aberturas horizontais, transparência constante, relação entre o interior e o exterior, uso de materiais locais (pedras), tradicionais (barro) e modernos (vidro e ferro) (ANDA, 1995, p. 196). O conjunto arquitetônico é expressivo no sentido em que integra arte e arquitetura e também pelos sistemas construtivos adotados, pela materialidade, pela relação com a topografia e vegetação existente, pela conformação dos espaços de passagens, pela relação entre áreas internas e áreas externas. Em uma entrevista para Arquine, o arquiteto e professor Humberto Ricalde (1942-2013) discorre sobre a Cidade Universitária:

O solo virou geometria plástica sobre qual se assentam esses edifícios da modernidade mexicana [...] Paulo Mendes da Rocha visitando Xochicalco e antes, passando pela UNAM comenta que para fazer arquitetura é preciso começar por construir o solo, é preciso antes pensar a construir o lugar". (RICALDI, 2013, informação verbal) ${ }^{4}$
3 "Ao sul do campus

situaram-se as escolas técnicas, ao norte as de humanidades, e no eixo do conjunto localizou-se a Reitoria, em frente à esta, a Torre de Ciências e nas periferia, os edifícios esportivos e

habitacionais ao mesmo tempo separados e conectados por um sistema viário perimetral inovador. Efetivamente, na Cidade Universitária, aplicou-se pela primeira vez um sistema de

circulações contínuas sem cruzamentos que rodeia todo o conjunto". (GARAY, 2004, p.57, tradução da autora).

4. Disponível em: https:// www.youtube.com/ watch?v=keq07m7UnLc

5. Mathias Goeritz, Helen Escobedo, Federico

Silva, Manuel Felguérez Hersúa, Sebstián e Roberto Acuña.

6. Dados encontrados no site oficial: http://www. fundacionunam.org.mx/ donde-paso/conoce-elespacio-escultorico-dela-unam/

Nas décadas seguintes foram sendo incluídos ao conjunto, em uma área anexa, novos edifícios como institutos, teatros, museus, centro para exposições e congressos, e o Espaço Escultórico (1977) com intervenções e esculturas de diversos artistas ${ }^{5}$ relacionando a arte com a própria reserva ecológica do Pedregal. Ao centro do Espaço Escultórico há uma intervenção que remete à zona arqueológica de Cuicuilco e aos cosmos. Trata-se de uma plataforma com 120 metros de diâmetro do lado externo, e 92,78 metros do lado interno, construída sobre lava vulcânica. Conformado por 64 módulos esculpidos de base retangular de 9x3 metros e 4 metros de altura ${ }^{6}$. É uma das intervenções mais emblemáticas da Universidade Autônoma do México.

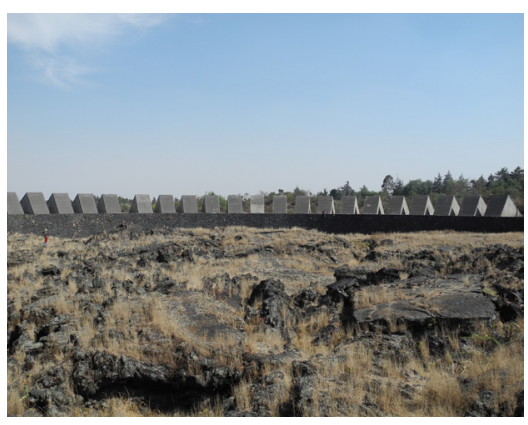

03

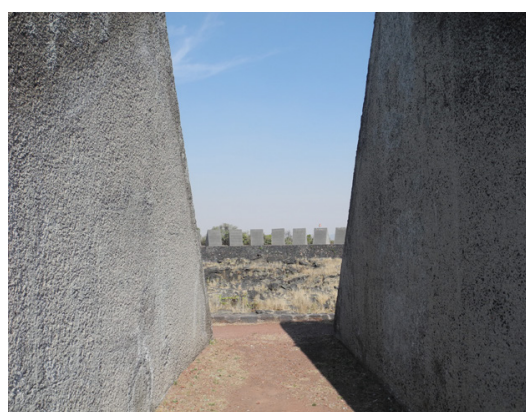

04

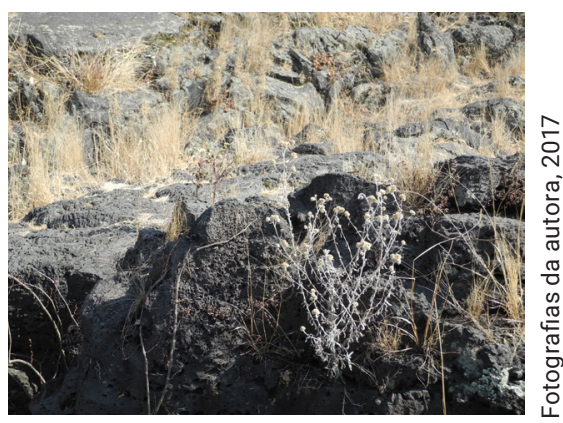

05 


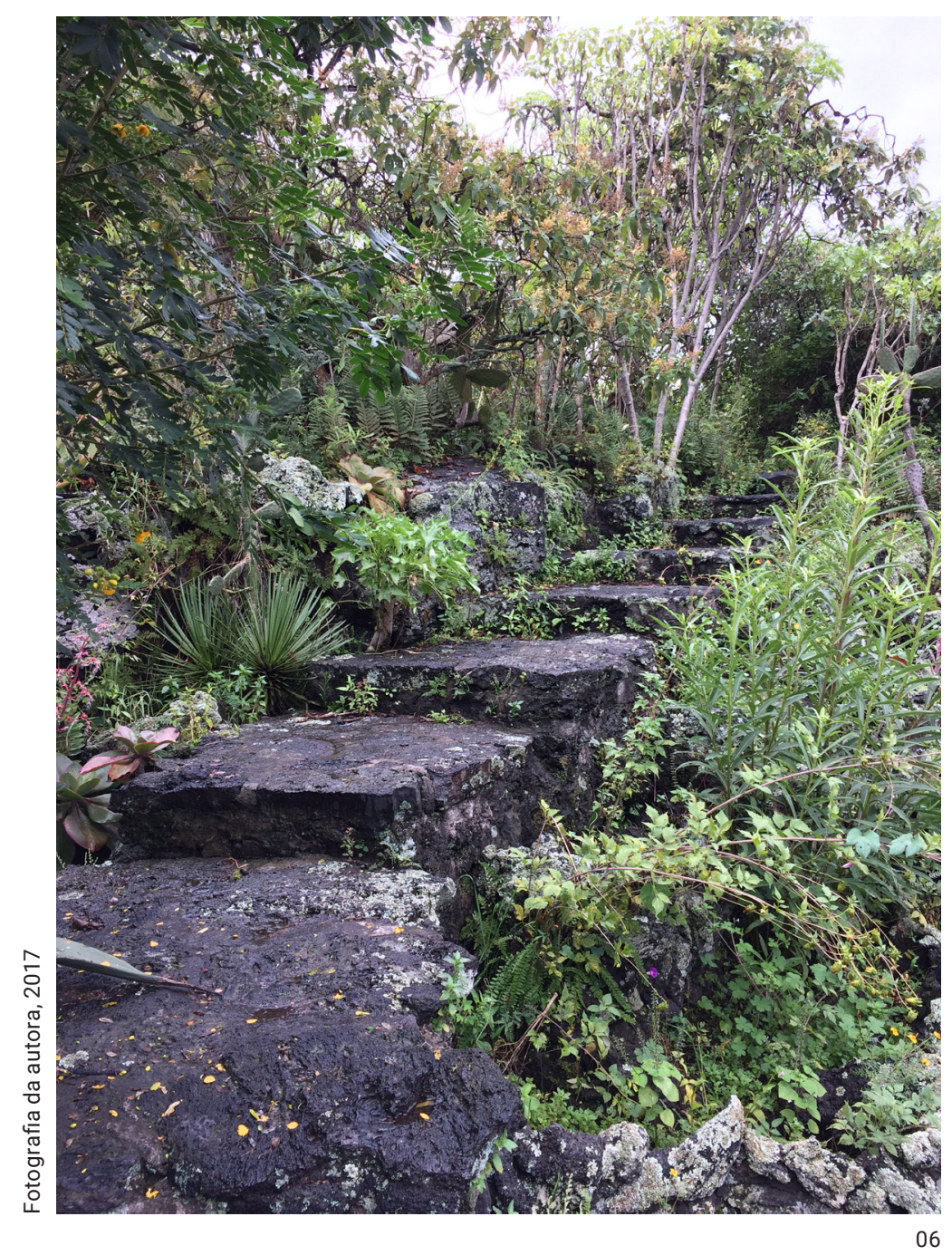




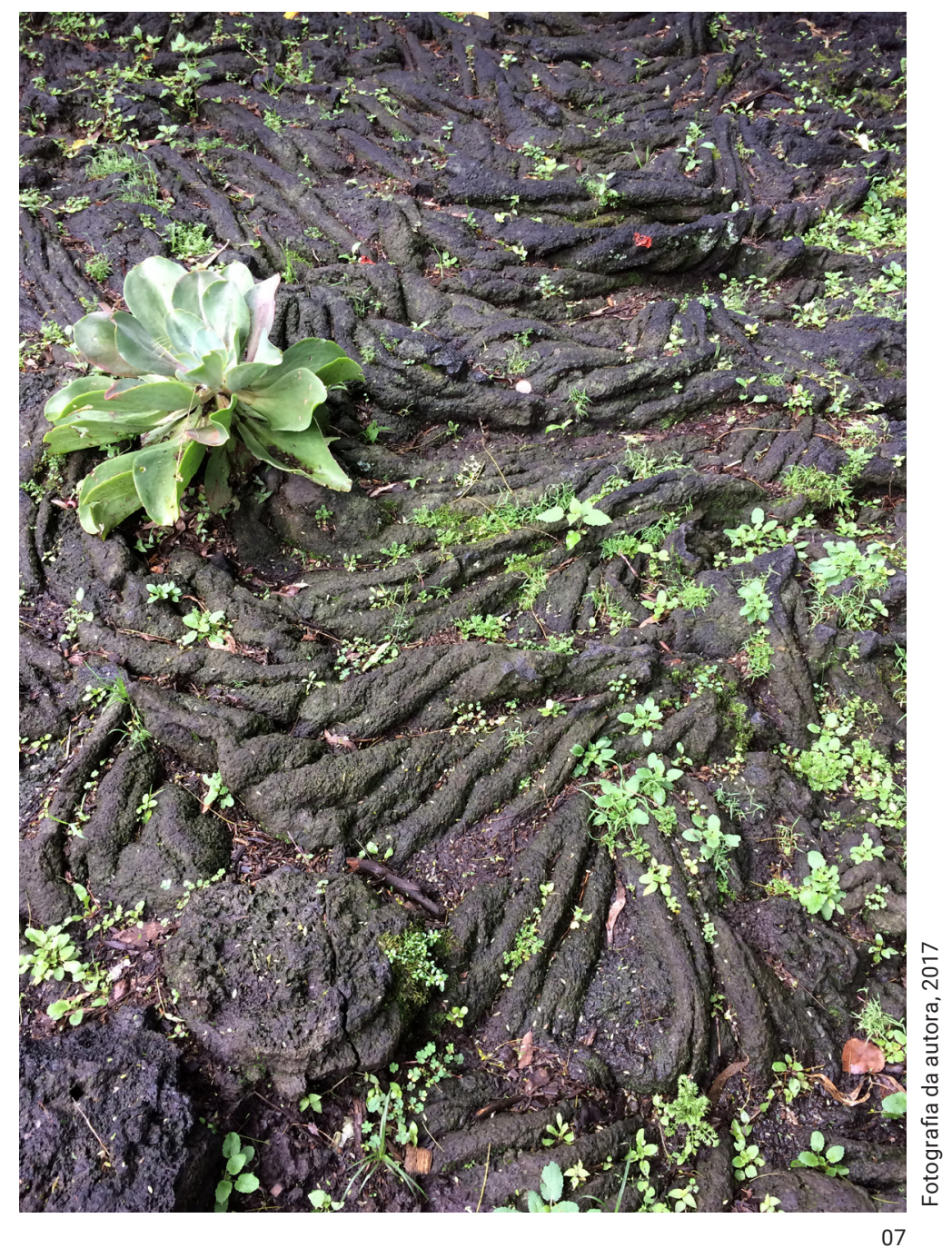


En una vasta extensión de lava al sur de la Ciudad de México me propuse, arrobado por la belleza de ese antiguo paisaje volcánico, realizar algunos jardines que humanizaran, sin destruir, tan maravilloso espectáculo. (BARRAGÁN, 1980, p. 60)7
Entre 1943 e 1945, Barragán compra um terreno na Avenida San Jerónimo, ao sul da cidade, denominado "El Cabrío" e nele realiza uma série de jardins privativos sobre a topografia existente conformada por pedra vulcânica e vegetação:

En los jardines de El Cabrío he querido crear espacios de pasión. La pasión es locura, es ambiente de ebriedad. Todas mis locuras - las que no me atrevo en vigilia - las hago en mis jardines [...] Su vegetación natural es asombrosa. Yo he querido trabajar con ella, y he experimentado aquí con mis ideas y dudas. (BARRAGÁN, 1945, p. 30 e 31) ${ }^{8}$

Em frente a esse terreno conformava-se uma área enorme de lava vulcânica, e segundo Barragán, de enorme potencial. Trata-se da área El Pedregal. A zona sul, diferentemente do restante da cidade caracterizada por seu solo argiloso, possui um solo rígido de pedra vulcânica por conta das diversas erupções dos vulcões Xitle, Cuatzontle, Oloica e La Magdalena que aconteceram entre 1500 e 2000 anos atrás, conforte estudos geológicos recentes (EGGENER, 2001, p.17). A lava vulcânica cobriu uma área de $80 \mathrm{~km} 2$, de 5 a 50 metros de profundidade levando também a destruição da cidade pré-hispânica Cuicuilco, alterando drasticamente a paisagem dessa região. Por muito tempo, a área ficou desabitada e no período Pós-clássico, os mexicas (ou nahuas) a chamavam de Tetlán, "lugar de pedras". Depois da chegada dos espanhóis, a área ficou conhecida como "Malpaís" e somente nos séculos XIX e XX, por conta de sua paisagem peculiar e beleza natural, começou a ser explorada por artistas, geólogos, antropólogos e arquitetos, entre eles Dr. Atl, José Clemente Orozco, Jesús “Chucho” Reyes.

Já em 1935, Diego Rivera havia escrito um documento com os requisitos para a organização do Pedregal (sendo publicado alguns anos mais tarde) ${ }^{9}$. Considerou as conformações geológicas do lugar e as condições climáticas favoráveis para a construção de habitações. Rivera não definiu o tamanho dos lotes, mas sua área livre para garantir a conservação geográfica natural do sítio (nos lotes com área inferior a $10.000 \mathrm{~m} 2$ a construção deveria ocupar no máximo um sexto do tamanho lote); as casas e jardins deveriam ser construídos a partir do próprio material existente na região (pedra vulcânica); haveria um limite de altura das construções; seria permitido o uso racional do concreto, vidro e aço, e telhados com telha seriam proibidos; estabeleceria-se um conselho estético composto por representantes do Departamento Central, da Secretaria de Educação Pública de México, da Universidade Nacional, do Colégio Nacional e de arquitetos e engenheiros para a aprovação das construções; as ruas teriam de duas à quatro faixas e a área
7. "Em uma vasta extensão de lava ao sul da Cidade do México me propus, encantado pela beleza desta antiga paisagem vulcânica, realizar alguns jardins que humanizaram, sem destruir, tão maravilhoso espetáculo". (BARRAGÁN, 1980, p. 60, tradução da autora).

8. "Nos jardins de El Cabrío quis criar espaços de paixão. A paixão é loucura, é ambiente de embriaguez. Todas minhas loucuras - as que não me atrevo em vigília - as faço em meus jardins [...] Sua vegetação natural é assombrosa. Quis trabalhar com ela, e tenho experimentado aqui minhas ideias e dúvidas". (BARRAGÁN, 1945, p. 30 e 31, tradução da autora).

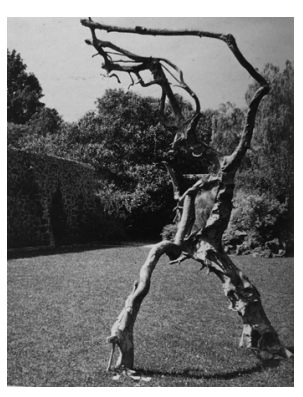

9. Artigo publicado em 1949 no jornal Novedades, segundo Keith L. Eggener em seu livro Luis Barragan's Gardens of El Pedregal Barragán teria acesso a esse documento antes dessa publicação, porque em 1945 discorre sobre o tema e toma os preceitos de Diego Rivera para a conformação do loteamento. 
poderia abrigar diversas espécies de vegetação (RIVERA, 1935, p. 24, 25 e 26). Rivera menciona Frank Lloyd Wright (1867-1959) como parâmetro de construção em Pedregal pelas condições propostas e resultado prático da obra do arquiteto norte americano. Barragán se atém em sintonia com esses princípios: "Es preciosa la vista, y es ahí donde podremos hacer vida moderna sobre jardines modernos" (BARRAGÁN, 1945, p. 31) ${ }^{10}$.

Em uma conferência nos Estados Unidos, ao discorrer sobre o Pedregal, Barragán afirma: "Benditos sean los desordenes geológicos!" (BARRAGÁN, 1951, p. 40).

Barragán lança os olhos sobre o Pedregal em meados da década de 1940, e compra uma área seis milhões de metros quadrados junto aos seus sócios Luis e José Alberto Bustamante em um momento de arquiteto investidor, com a intenção de realizar um loteamento residencial através de um audacioso plano urbanístico e paisagístico que respeitasse ao máximo as características naturais e existentes:

En la subdivisión de los Jardines de El Pedregal - con las exageraciones propias de la formación barroca de sus texturas y formas - hemos encontrado que, para no dañar o estropear la belleza del paisaje y poder crear formas arquitectónicas bellas que no compitieran con ella, éstas debían ser de absoluta simplicidad: abstractas en cualidad, preferentes líneas rectas, superficies planas y formas geométricas primarias. (BARRAGÁN, 1951, p. 40) ${ }^{11}$

Com a consolidação da Cidade Universitária, localizada também sobre essa geografia ao sul da cidade, e com o apoio do arquiteto e urbanista Carlos Contreras (1892-1970) - responsável por diversos projetos de desenvolvimento urbano neste período - surge o loteamento "Jardines de El Pedregal de San Ángel". Barragán passou a visitar a área acompanhado do pintor e vulcanólogo Dr. Atl e do fotógrafo Armando Salas Portugal' ${ }^{12}$, este último havia apresentado em 1944 uma exposição individual no Palácio Bellas Artes "Exposición Fotográfica del Paisaje Mexicano" com 14 fotografias de Pedregal, com as vistas dos vulcões, paisagem e vegetação deste lugar. Barragán propõe ao fotógrafo que trabalhe para ele, fazendo a documentação fotográfica dessa área, e posteriormente de suas obras.

Em atenção aos preceitos de Diego Rivera, Barragán escreve também outros preceitos para o desenvolvimento do projeto envolvendo desde o partido arquitetônico até sua divulgação para a venda. Era uma área inóspita da cidade, desabitada por muitos anos, e Barragán estava preocupado também com a venda dos terrenos, por isso a atenção com a publicidade. Toma como base os requisitos de Diego Rivera e neste documento afirma que o loteamento deveria ter o caráter de um parque; uma relação harmoniosa entre arquitetura e paisagem; além das casas, contaria com um hotel, um parque, uma igreja e jardins - construídos a partir do aproveitamento de materiais locais; o folheto de publicidade deveria ter um caráter de livro de arte, mostrando o potencial do lugar; e um curta poderia passar nos cinemas antes das sessões (BARRAGÁN, 1944, p. 22 e 23).

O projeto não acontece em sua totalidade, e atualmente pouco se pode reconhecer do projeto original. 0 parque residencial deveria deixar em estado virgem $2 / 3$

10. "É preciosa a vista, e é aí onde podemos fazer vida moderna sobre jardins modernos" (BARRAGÁN, 1945, p. 31, tradução da autora).

11. "Na subdivisão de Jardines de El Pedregal com o exagero próprio da formação barroca de suas texturas e formas - nos demos conta que para não danificar ou estropiar a beleza da paisagem e poder criar formas arquitetônicas belas que não competem com ela, estas deveriam ser de absoluta simplicidade: abstratas em qualidade, preferencialmente de linhas retas, superfícies planas e formas geométricas primárias". (BARRAGÁN, 1951, p. 40, tradução da autora).

12. Barragán toma contato com as

fotografias de Armando

Salas Portugal na exposição individual do fotógrafo no Palacio de Bellas Artes em 1944 (CANALES, 2013, p. 81). 
da superfície total de cada lote, o menor de $10.000 \mathrm{~m} 2$ só poderia alterar $10 \%$ a paisagem existente. 0 desenho das ruas seguiam o fluxo da lava vulcânica, conformando o desenho da paisagem. As ruas e avenidas foram nomeadas de Lava, Rocha, Cratera, Água, Fogo, Chuva, Brisa, Nuvens, entre outros.

Jardines de El Pedregal surge a partir do lugar, reconhecendo neste território suas qualidades específicas. Tomando o pensamento de Christian Norberg-Schulz (19262000) como fio condutor para a reflexão sobre este projeto, e de que a ação do homem sobre o lugar transforma a natureza em paisagem cultural, Luis Barragán entende o espírito do lugar, com habilidade de criar seus significados através de suas construções, texturas e cores. A tectônica entra fundamentalmente. "A arquitetura pertence à poesia, e seu propósito é ajudar o homem a habitar" (NORBERGSCHULZ, 1976, p. 459). Era o desejo de uma nova cidade possível, nessa relação entre lugares naturais e lugares criados pelo homem.

Em colaboração com Max Cetto realiza dois exemplos de casa para a venda, localizadas na Avenida de las Fuentes, lotes 10 e 14 (atuais 130 e 140). Essas casas buscavam a relação com a topografia natural dos terrenos e o uso de materiais locais, em uma nova maneira de entender o moderno (CANALES, 2013, p. 81). 0 acesso ao loteamento se dá próximo à essas casas, e originalmente era composto por um grande portão metálico, uma fonte com um jato de água que disparava na vertical, por altos muros de pedra vulcânica com diversas alturas e uma escultura que Luis Barragán pediu exclusivamente para Mathias Goeritz (CETTO, 2017, p.62). A serpente de concreto, Animal del Pedregal, remete a fauna da região. A fonte foi incorporada ao jardim particular de umas das casas circundantes ao acesso.
Las obras realizadas en el impactante entorno del Pedregal, cuyos terrenos próximos fueron pronto colonizados por Ciudad Universitaria, constituyen una de las más claras representaciones de la producción singular, tan arraigada en lo local como vanguardista, de la arquitectura moderna en México. (CANALES, 2013, p. 81) ${ }^{13}$

Barragán propôs também a Plaza del Cigarro, definidos por muros de concreto e uma torre cilíndrica, compondo o desenho de um espaço público dentro do loteamento. E entre 1948-1951 projetou e construiu a Casa Prieto López, também na Avenida de las Fuentes, sob esses preceitos. A experiência de Pedregal leva Barragán a projetar e desenvolver posteriormente outros loteamentos tanto na Cidade do México quanto em Guadalajara (Arboledas, 1958-1963; Jardines del Bosque, 1955-1958; Los Clubes, 1961-1972; e em parceria com o arquiteto Juan Sordo Madaleno o complexo residencial Lomas Verdes, 1964-1965).

Embora "Jardines del Pedregal de San Ángel" tenha sido um êxito na época, a utopia da paisagem ajardinada não permaneceu ao longo dos anos. Por falta de leis rígidas de preservação e conservação, pouco é possível ser reconhecido do projeto original e muitas das construções não seguiram os requisitos de Barragán. Ainda é possível encontrar vestígios das pedras vulcânicas camufladas entre os altos muros das residências e o mais parecido com a paisagem da época está localizado na reserva ecológica da UNAM. 


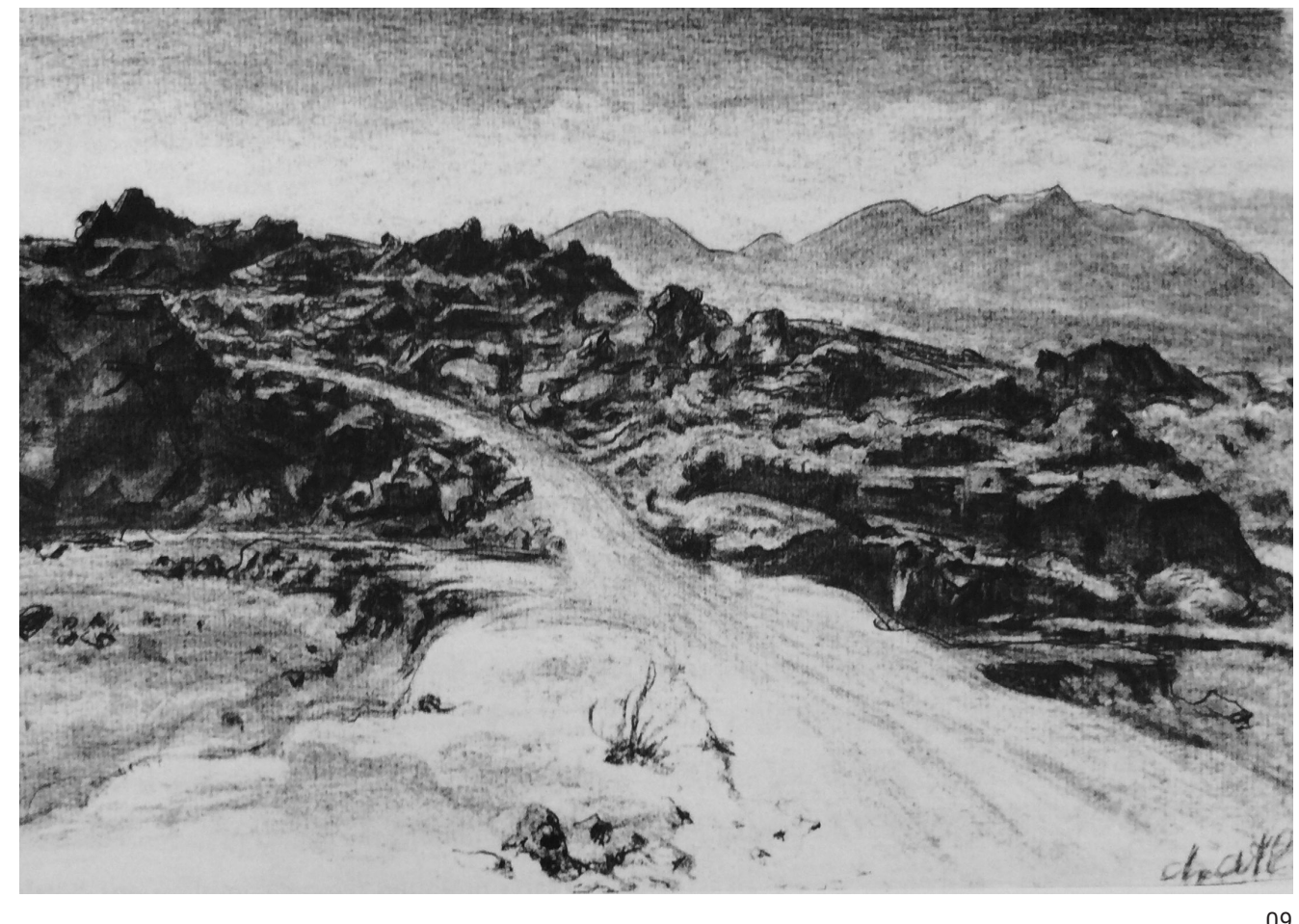

El Pedregal, Dr. Atl , 1946

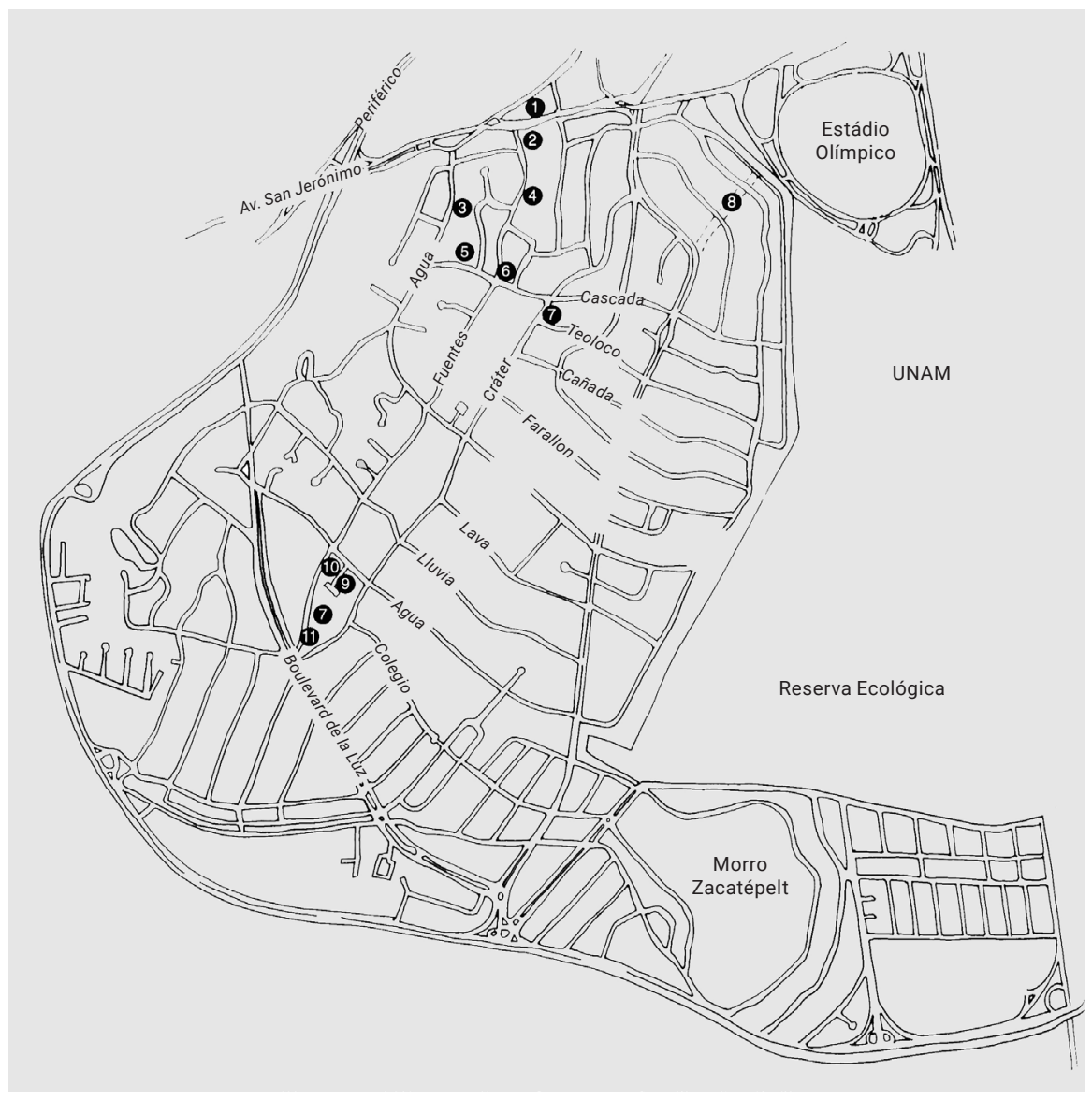

1. El Cabrío

2. Plaza de las fuentes

3. Casa Max Cetto

4. Casas mostras

5. Jardins mostras

6. Casa Prieto López

7. Parque público

8. Rotatória / acesso serviços

9. Plaza del Cigarro

10. Centro comercial

11. Igreja católica 

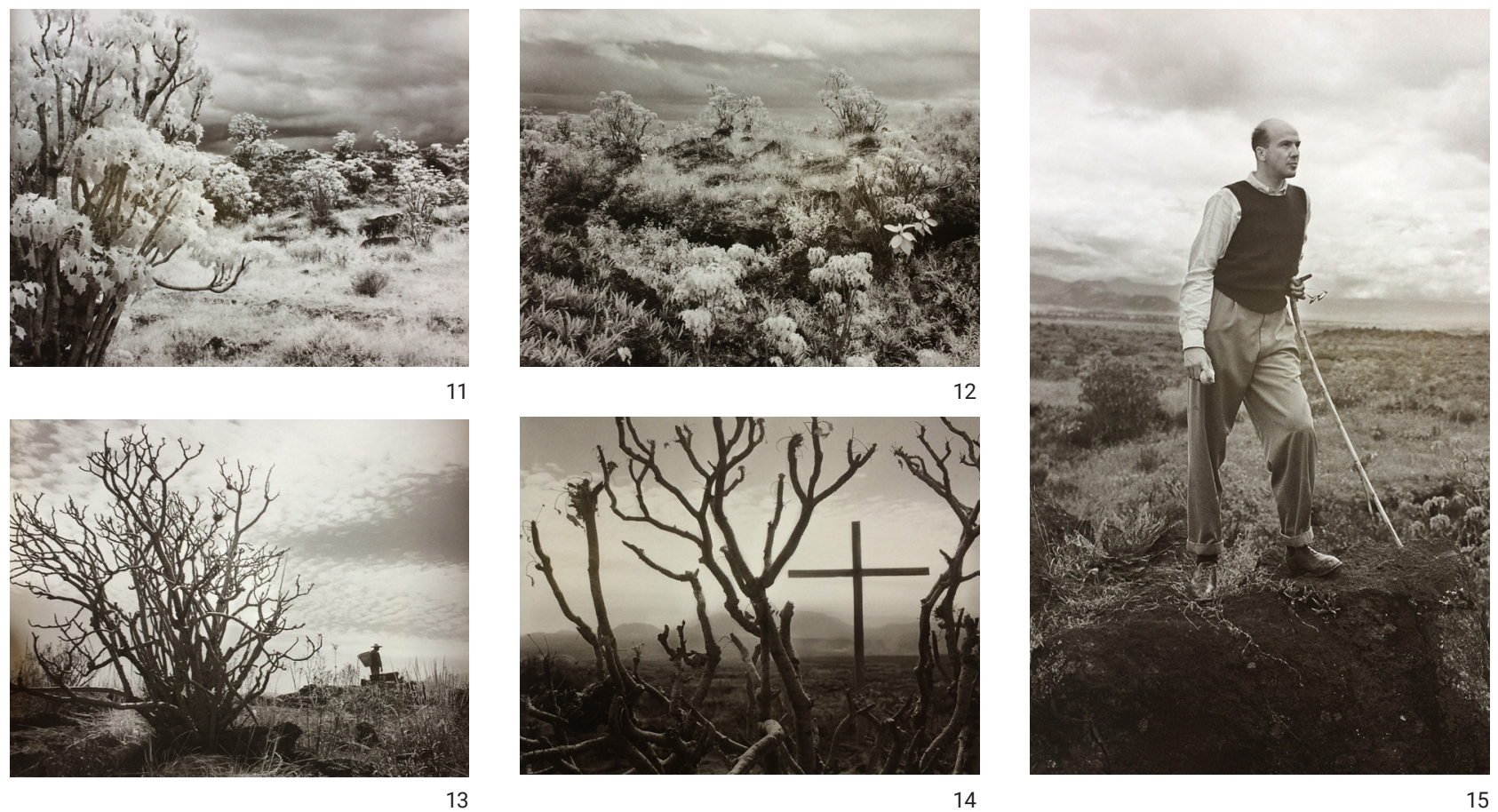

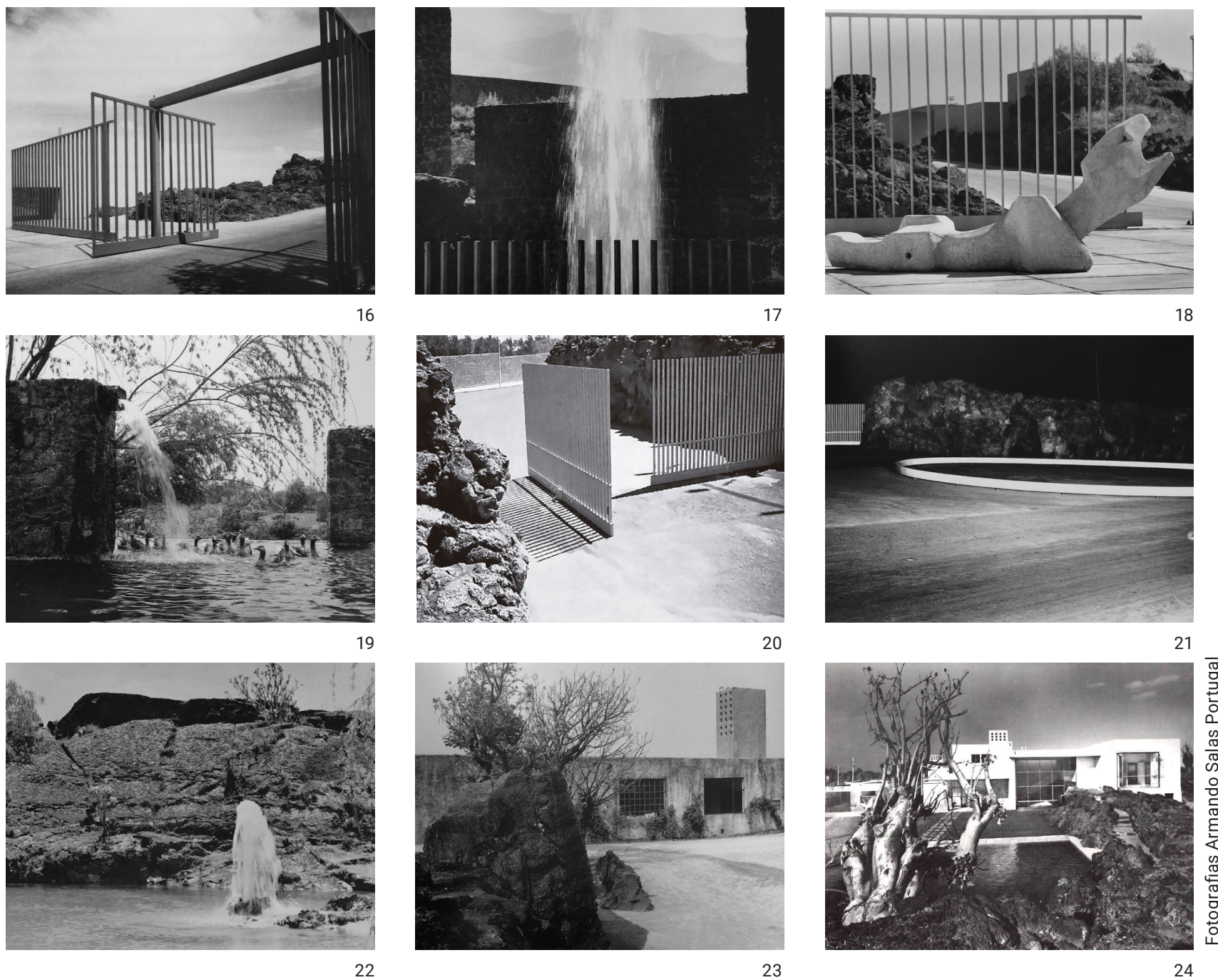


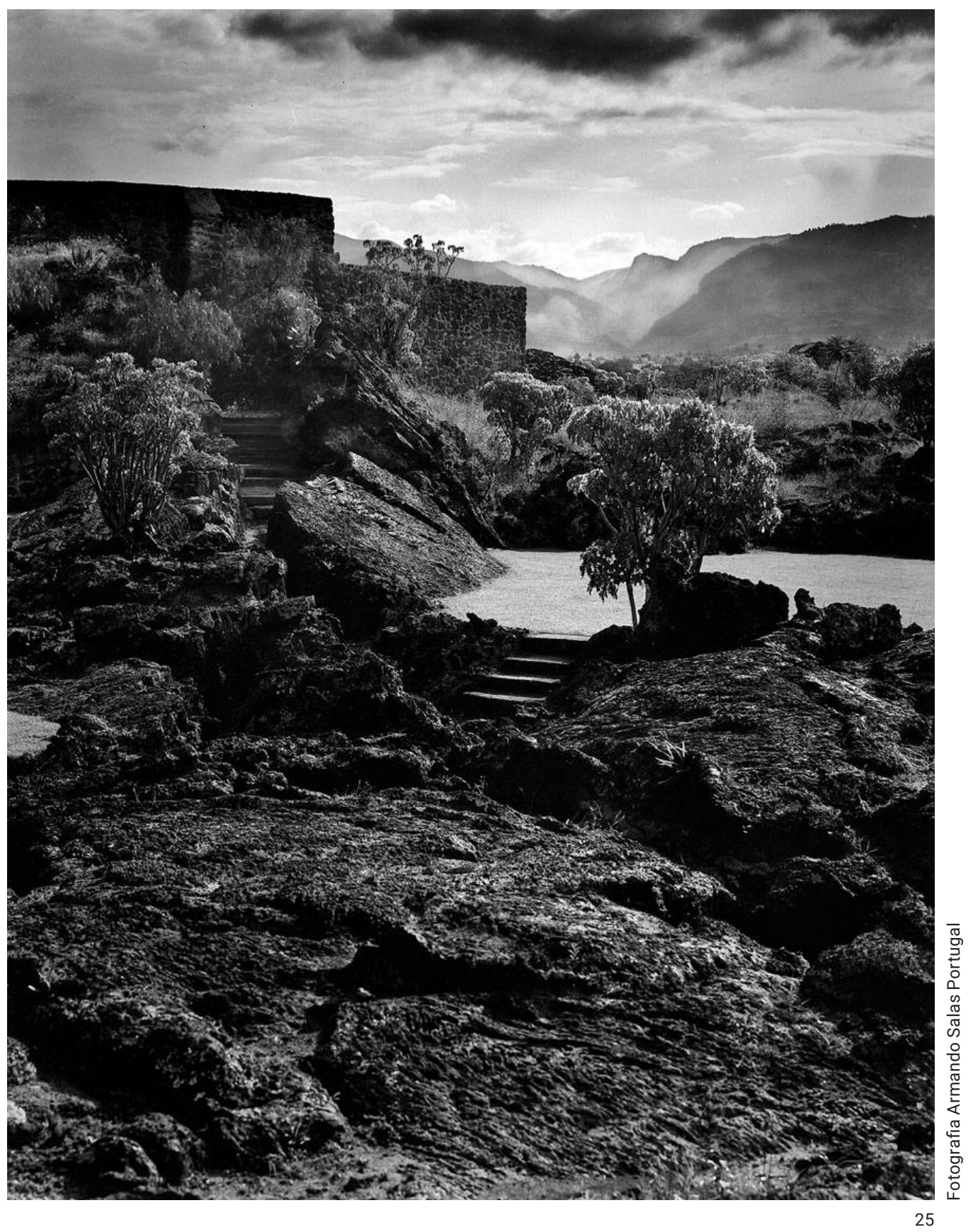




\subsection{Construções em Tacubaya . o desenho das casas}

Em paralelo ao projeto de "Jardines de El Pedregal de San Ángel", no mesmo período, Barragán compra alguns terrenos no bairro popular Tacubaya, e desenvolve jardins privados em uma menor escala. Localizados na antiga Calzada de Madereros (hoje Avenida Constituyentes), entre o centro histórico da Cidade do México e o Parque Chapultepec, Barragán desenvolve livremente o desenho desses jardins.

"Hay que buscar que las casa sean jardines, y los jardines sean casas" (BARRAGÁN, 1931, p. 15) ${ }^{14}$. Esse período faz Barragán ganhar o reconhecimento como arquiteto paisagista e de arquiteto urbanista, também pelos projetos de loteamentos, passando de uma escala íntima, para uma escala urbana. Nestes lotes, realiza também algumas construções. 0 bairro de Tacubaya era conformado por tipologias tradicionais mexicanas com residências de pequena escala e por comércio local (borracharias, lojas de materiais de construção e pequenos restaurantes). Atualmente novas construções surgiram, como edifícios mais altos, galerias de arte e instituições culturais ocupam a mesma rua.

O primeiro projeto nesse conjunto de construções que Barragán realiza no bairro de Tacubaya é a sua primeira casa, localizada na Rua General Franciso Ramírez, nos números 20 e 22, conhecida atualmente como Casa Ortega (1941-1943). Barragán define os muros colindantes em um lote em "L", onde já havia uma casa existente. 0 projeto consiste na remodelação da casa existente, sua ampliação e o desenho dos jardins. Os volumes são articulados espacialmente entre o interior e o exterior através de suas aberturas e pátios. Barragán tira partido da situação existente do terreno a partir desnível já dado, e conforma diversos platôs com vegetação, caminhos, escadas e taludes de contenção. No terreno também existem galerias subterrâneas por conta de uma antiga mina de areia, e que segundo o escritor Salvador Novo (1904-1974) configuravam misteriosas passagens de efeitos surrealistas (ZANCO, 2011, p. 97). Utiliza pedra para o desenho dos percursos, posiciona esculturas clássicas, sagradas e objetos da cultura local pelo vasto jardim, e inclui ao fundo do terreno, quase escondido, um tanque de água. Estes jardins se conformam como um lugar contemplativo, de recolhimento e de surpresas. Com o passar do tempo, uma das laterais da casa ficou imersa nessa vegetação.

Ao visitar a Cidade do México, recebido por Diego Rivera, Vladimir Maiakovski (1893-1930) repara na configuração urbana da cidade e comenta:

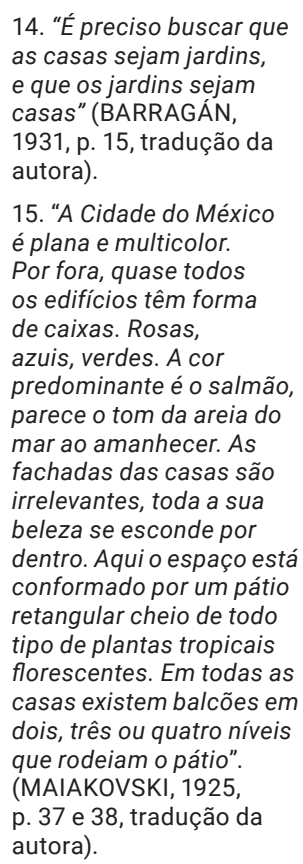

La Ciudad de México es plana y multicolor. Por afuera, casi todos los edificios tienen forma de cajas. Rosas, azules, verdes. EI color dominante es el salmón, parecido al tono de la arena del mar al amanecer. Las fachadas de las casas son anodinas, toda su belleza se esconde adentro. Aquí el espacio está conformado por un patio rectangular lleno de todo tipo de plantas tropicales florecientes. En todas las casas hay balcones en dos, tres o cuatro niveles que rodean el patio. (MAIAKOVSKI, 1925, p. 37 e $38)^{15}$ 
Maiakovski provavelmente se referia às construções do centro histórico e de Coyoacán, bairros com construções tipicamente de origem espanhola. As fachadas das casas, com poucas aberturas para a rua, preservam a intimidade dos espaços domésticos. De certo modo, Barragán interpreta essa cultura, e seus projetos residenciais a partir deste período, não demonstram ao exterior todo seu valor e a configuração dos espaços internos.

A segunda construção realizada em Tacubaya é sua segunda casa, onde vive até a sua morte, localizada na Rua General Franciso Ramírez, número 14. A casa situa-se no terreno vizinho à Casa Ortega e é considerada pela historiografia mexicana, sua obra principal. A Casa Estúdio (1947-1948) foi também seu laboratório de experimentações. Os muros na cobertura, por exemplo, foram modificados algumas vezes ao longo de sua vida. No lote vizinho a casa, no número 12, Barragán mantinha seu estúdio. Os lotes, com acessos distintos pela rua, compartilham o mesmo jardim ao fundo do terreno. Atualmente encontram-se em excelente estado de preservação, e o conjunto é aberto para a visitação. A Fundação Luis Barragán da Cidade do México toma como sede esta casa, tornando-a um museu. Voltadas para o interior do lote, as construções passam-se despercebidas pela rua. Mantém o alinhamento da calçada contínuo a Casa Ortega. Até hoje preserva os aspectos originais do projeto, inclusive na disposição do mobiliário (desenhando por Barragán e Clara Porset) e seus objetos pessoais (pinturas de Jesús "Chucho" Reyes, Miguel Covarrubias e Mathias Goeritz; reproduções de obras de arte de Picasso, Josef Albers, Mondigliani, por exemplo; fotografias; objetos religiosos; artesanatos da cultura popular; objetos africanos; cerâmicas de Jalisco e Puebla; esferas de vidro; entre outros) (ZANCO, 2010, p. 102). A casa conforma-se entre espaços íntimos, e assimila-se a um labirinto. Barragán desenha precisamente as circulações, escadas e altura dos ambientes, utilizando em muitos momentos fechamentos leves, como biombos, entre um cômodo e outro. Espacialmente complexa, ora com ambientes intimistas, ora com ambientes amplos. As aberturas são estrategicamente posicionadas e a entrada de luz natural é sempre controlada. Nos dormitórios, por exemplo, Barragán desenhou um fechamento em madeira, com quatro aberturas, muito semelhantes às janelas de Alhambra. Nos panos de vidro voltados ao jardim, tanto na sala, quanto nos quartos, fez uso de cortinas.

A casa possui três pavimentos distribuídos em distintos níveis, e o programa distribui-se entre áreas sociais e de serviços no térreo, e áreas íntimas no segundo pavimento. Sempre com ambientes de transição entre um cômodo e outro. 0 acesso a casa faz-se por um vestíbulo, limite entre a rua e o espaço íntimo, este primeiro ambiente da casa configura-se como uma espécie de filtro. Conformado por piso de pedra vulcânica e revestimento de madeira em uma das paredes, um vidro na cor âmbar posicionado na porta de entrada já deixa esse primeiro espaço da casa em tons amarelados. Um generoso banco de madeira e uma luminária completam o ambiente. 0 teto é baixo e sugere uma sensação de confinamento. 0 próximo ambiente, o hall de distribuição para outros cômodos da casa é generoso em altura, e recebe em algumas paredes a intensa cor rosa. Jogos de luz através de uma alta abertura direciona a luz que reflete na obra dourada de Mathias Goeritz posionada no patamar da escada de acesso ao pavimento superior. 0 desenho da luz é altamente sofisticado. A cor ganha volume, o piso de pedra 
vulcânica potencializa o valor tectônico. Na sala de estar, primeiro ambiente com pé direito duplo, a relação visual com o jardim é direta. Do mobiliário em madeira desenvolvido com Clara Porset, destacam-se as cadeiras butacas e o facistol. O facistol é um mobiliário de origem religiosa, colocado nos coros das igrejas como suporte de livros. Na sala de sua casa, Barragán o posicionou para apoiar as imagens de referências que alimentavam seu processo criativo. Na biblioteca, também com pé-direito duplo, a escada de madeira embutida na parede, remete à escada do Ático de Beistegui de Le Corbusier.

0 acesso ao estúdio por dentro do lote faz-se através do jardim, passando por um pátio com vasos posicionados livremente e um espelho de água com uma fonte, a presença da água e de vasos na paisagem configuram este espaço. 0 estúdio contempla uma cobertura com vigamento de madeira inclinado com uma abertura zenital. 0 grande caixilho que delimitava a área interna do estúdio com o jardim, mantendo a relação visual com a natureza, foi substituído por uma parede grossa de piso a teto. Já não é possível observar o jardim de dentro do estúdio.

Na cobertura, rodeada por muros altos, destacam-se os volumes das chaminés. Conformada por uma área reservada, denominada como fachada para o céu, resulta um dos espaços mais emblemáticos da casa (ZANCO, 2010, p. 106). Sobre a cobertura, Barragán afirma em uma entrevista para Elena Poniatowska:

El paisaje de De Chirico, y de muchos de los surrealistas, está caracterizado por la soledad; y muchos de mis ambientes - la terraza misma de aquí arriba, en mi casa - no podrían recordar sino la soledad de un cuadro de De Chirico. (BARRAGÁN, 1976, p. 120$)^{16}$

Barragán alimenta-se constantemente de suas fontes, referências e experiências vividas. Traduz nos desenhos seus desejos. Remete às construções das fazendas antigas do México ao fazer uso de vigamento de madeira. As aberturas, estrategicamente posicionadas, confirmam seu discurso e mantêm um espaço doméstico íntimo, voltado ao interior. Faz uso da luz natural, e posiciona as luminárias nos mobiliários, nunca no teto. 0 uso de vidro na cor âmbar em algumas das janelas lava o ambiente de dourado em alguns recintos. Utiliza nos materiais pedra vulcânica e madeira e faz uso de cor em algumas paredes.

A quarta construção nesta mesma rua, localizada no número 17 , consiste em um jardim e uma edícula ao fundo do terreno, onde funcionava um anexo de seu ateliê. Também aberto à visitação atualmente, abriga exposições de arte. Esculturas de dorsos femininos e masculinos estão espalhadas entre o jardim e um tanque de água. Os muros laterais do jardim recebem a cor azul anil.

Este conjunto de construções em Tacubaya mantêm um forte vínculo com a natureza: a Casa Ortega, é quase absorvida pela vegetação; a Casa Estúdio, com um jardim selvagem possível de ser visto de diversos ambientes de dentro da casa, ocorre como paisagem central; e o anexo do ateliê, do outro lado da rua, localizado ao fundo do lote, com acesso através do jardim. Nos anos seguintes, Barragán 
realiza mais algumas casas muito parecidas com os preceitos destes projetos e também faz uso de ambientes de transição; de pátios; de fontes; de vigamentos de madeira; de grandes aberturas de vidro nas salas voltadas para um jardim interno; de objetos vernaculares; de cor; de mobiliário de madeira; de biombos; entre outros. (Casa Gálvez, 1955; Casa Egerstrom, 1966-1968; Casa Gilardi, 1975-1977 e Casa Meyer, 1978; todas na Cidade do México).
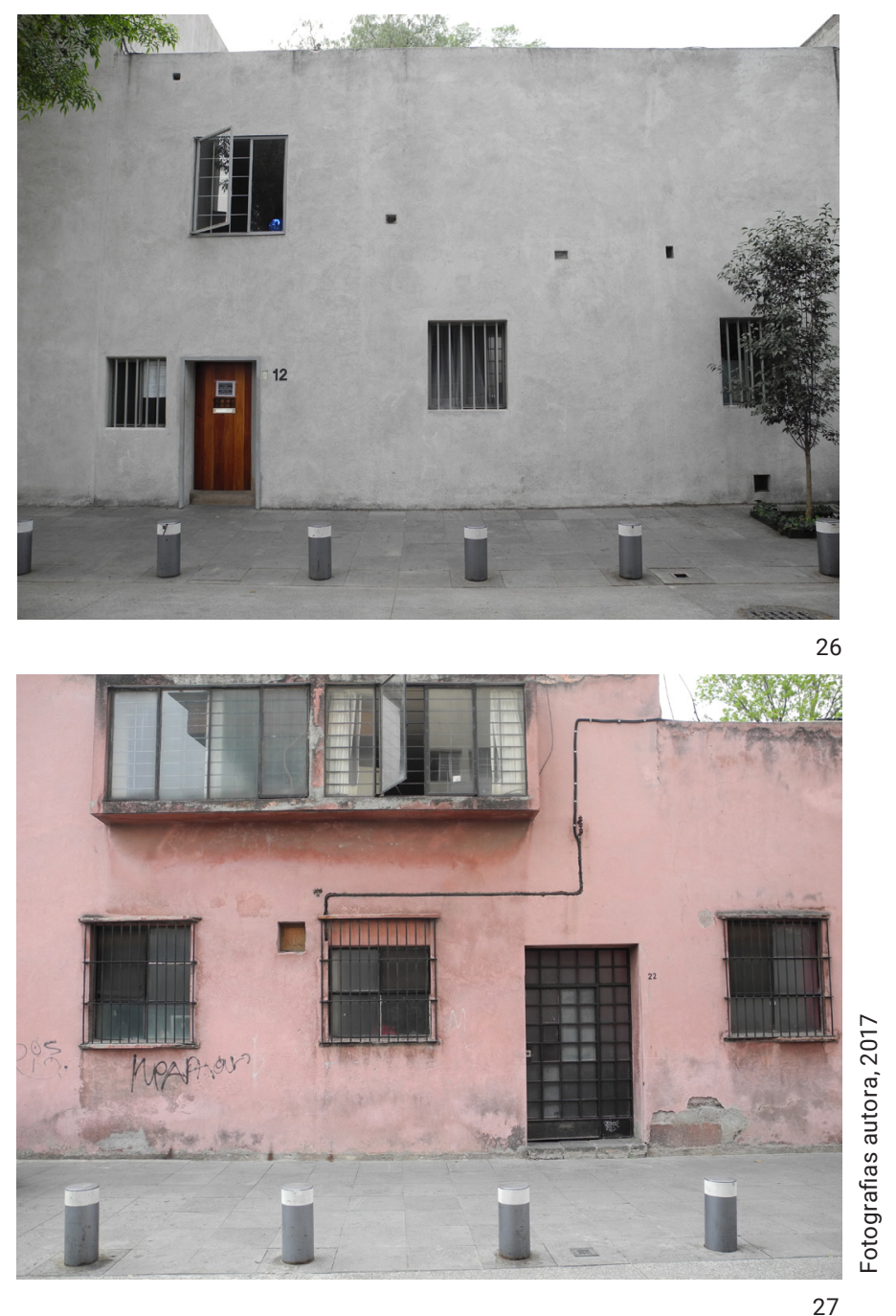


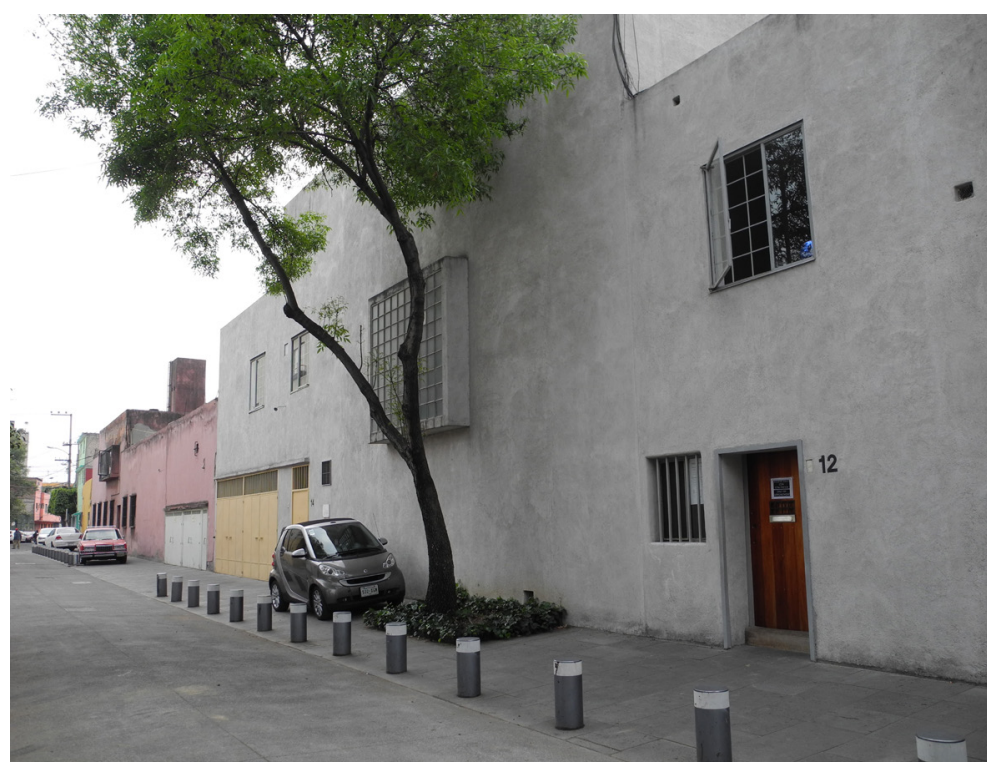

28

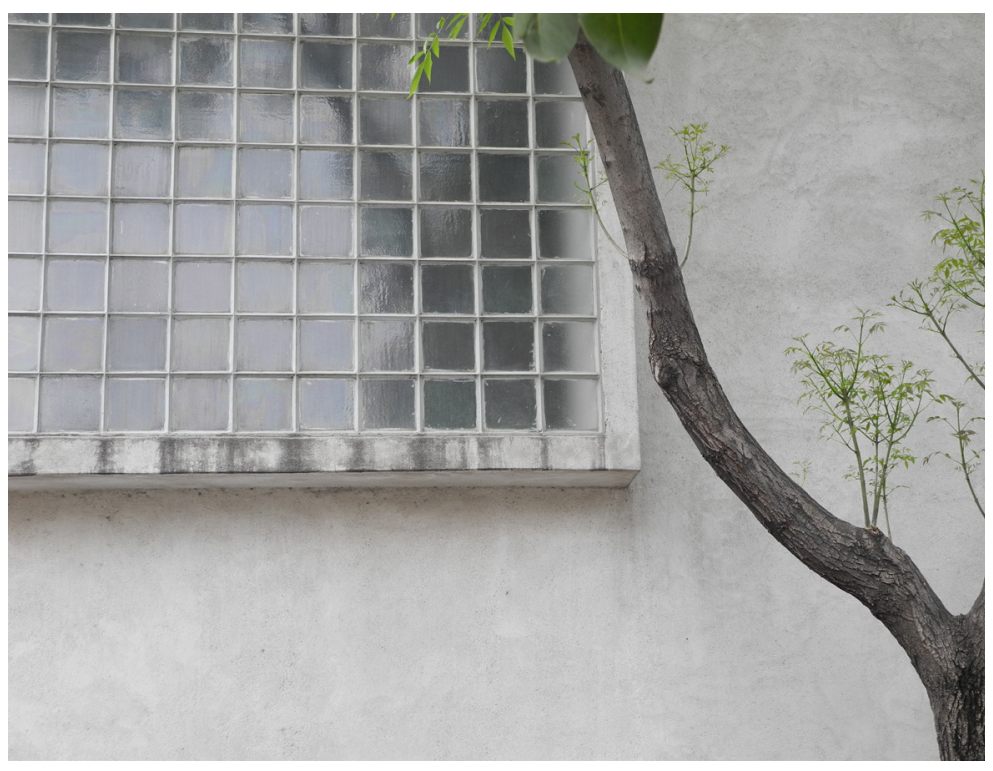

29

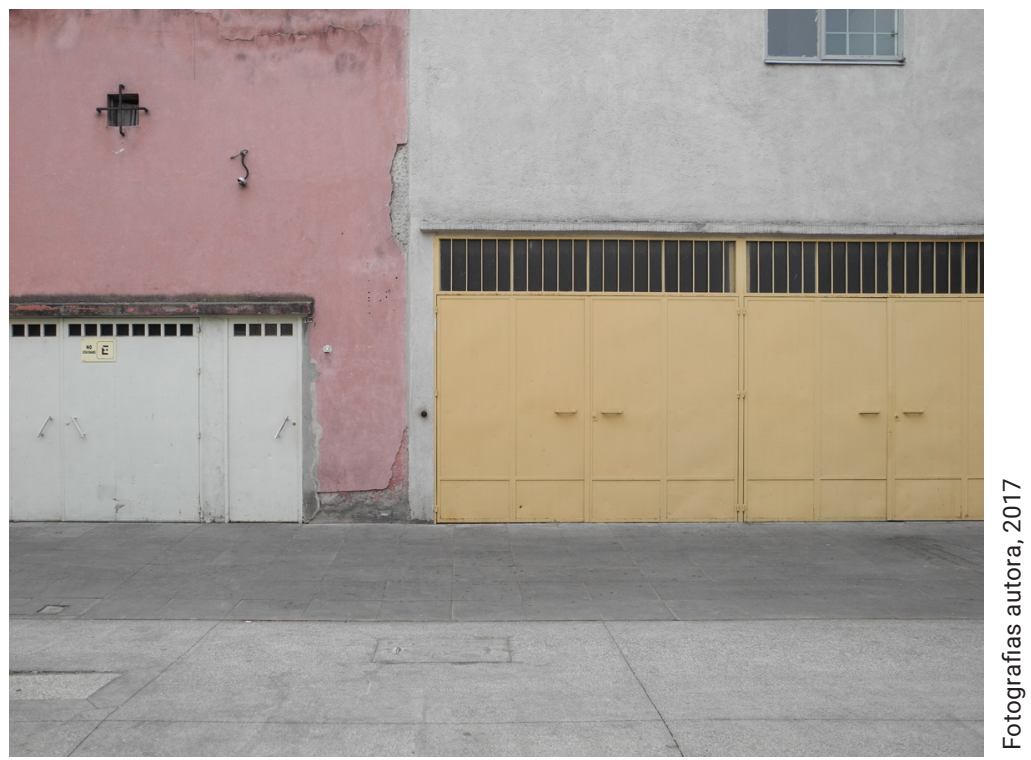

30 


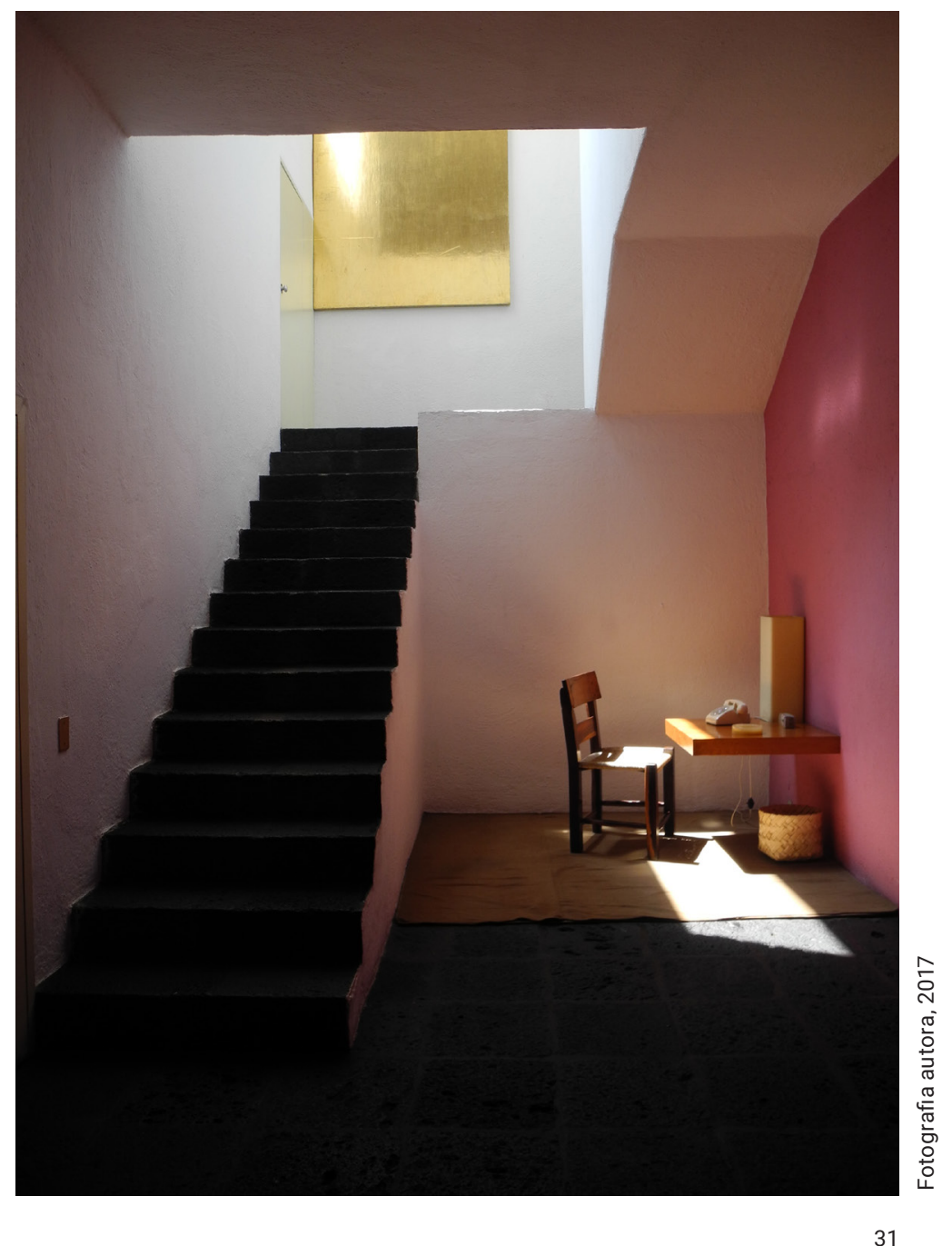



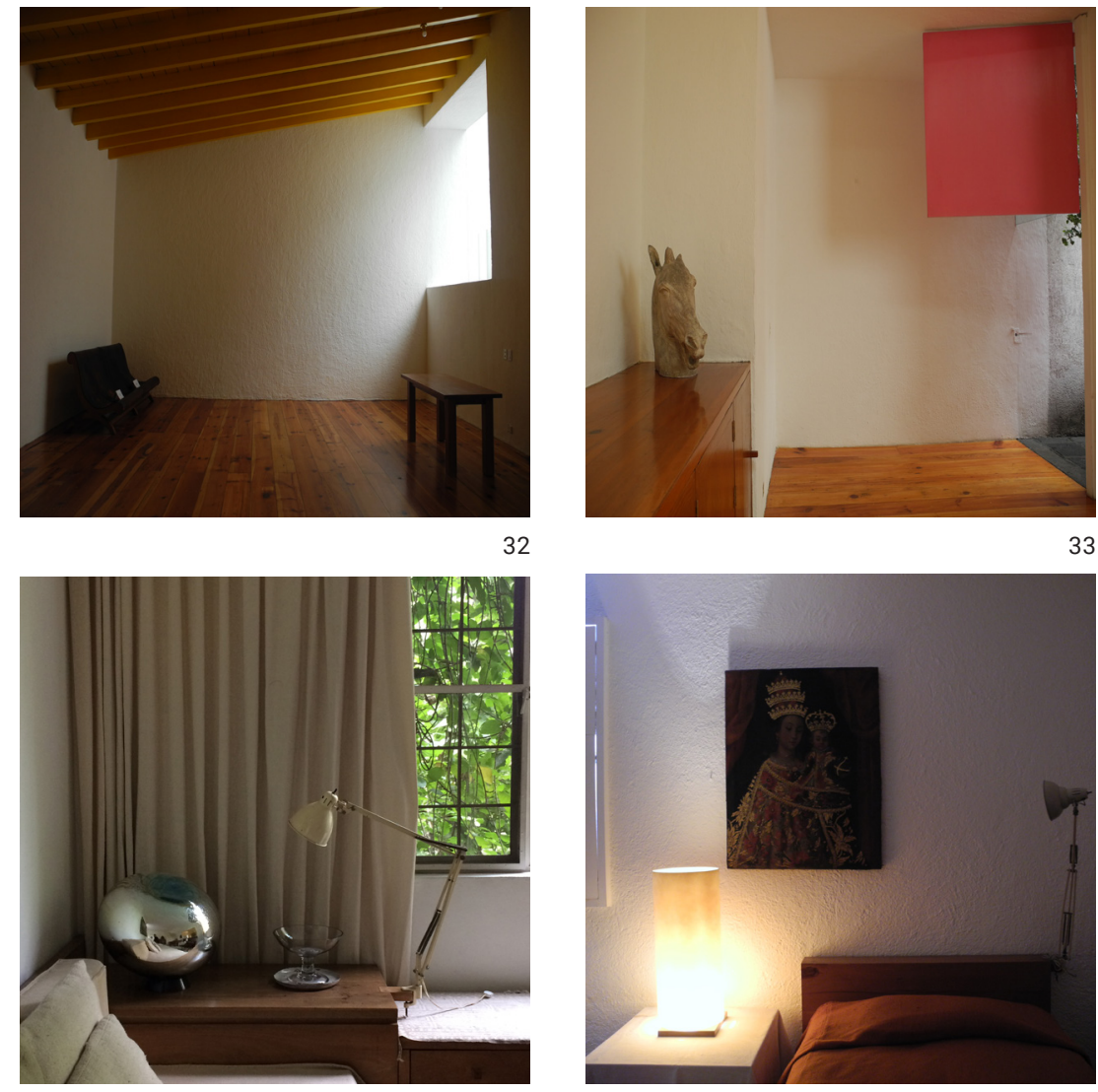

35
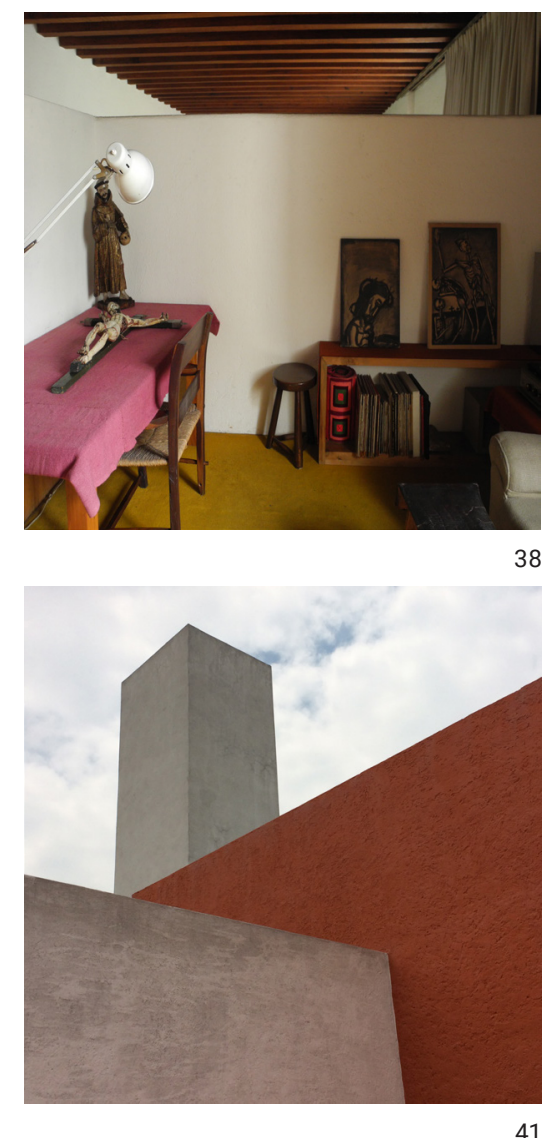
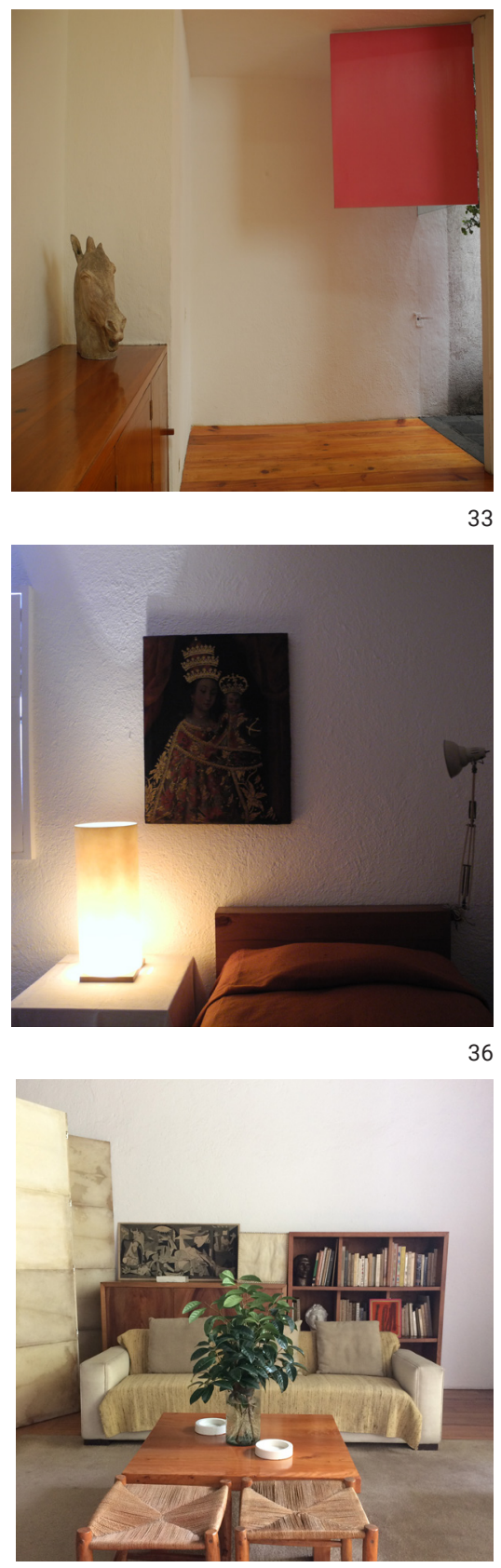

39

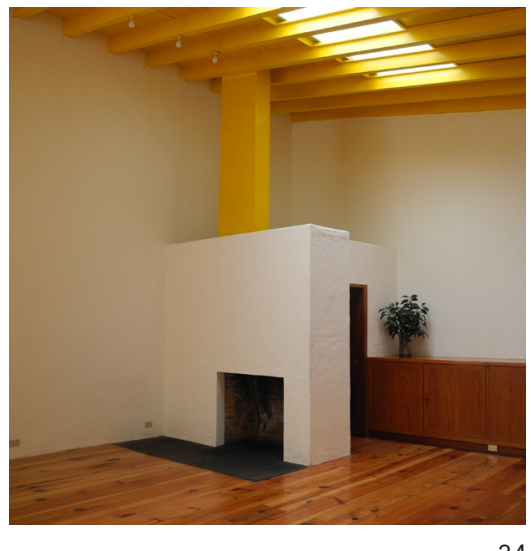

34

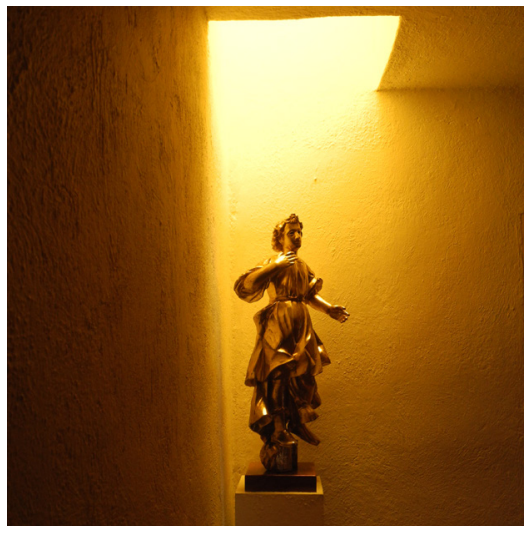

37

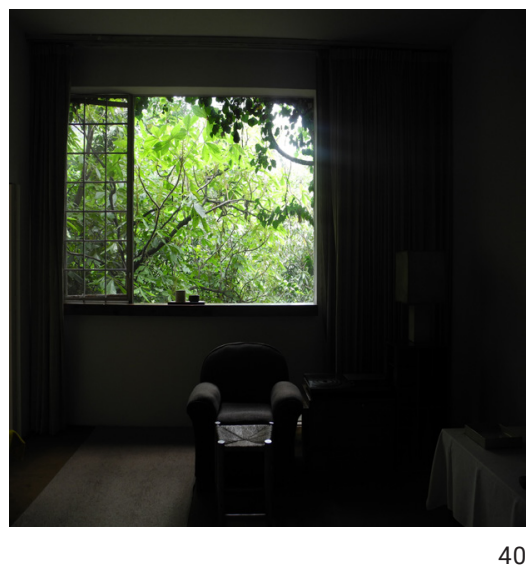

40

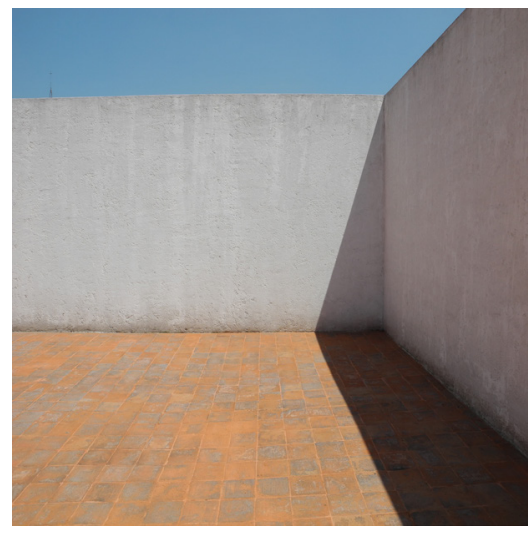

42

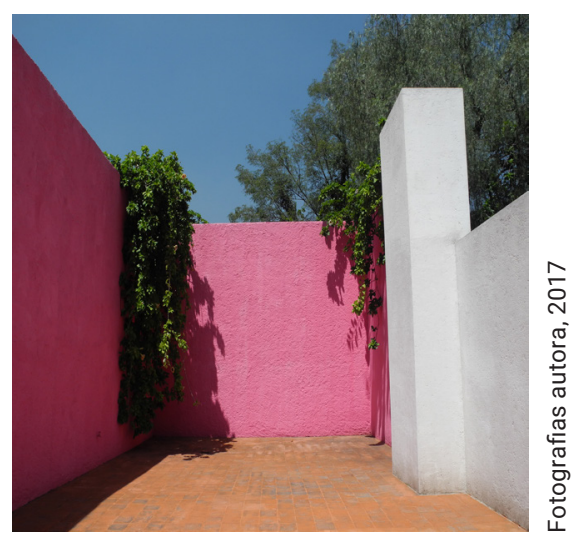

43 

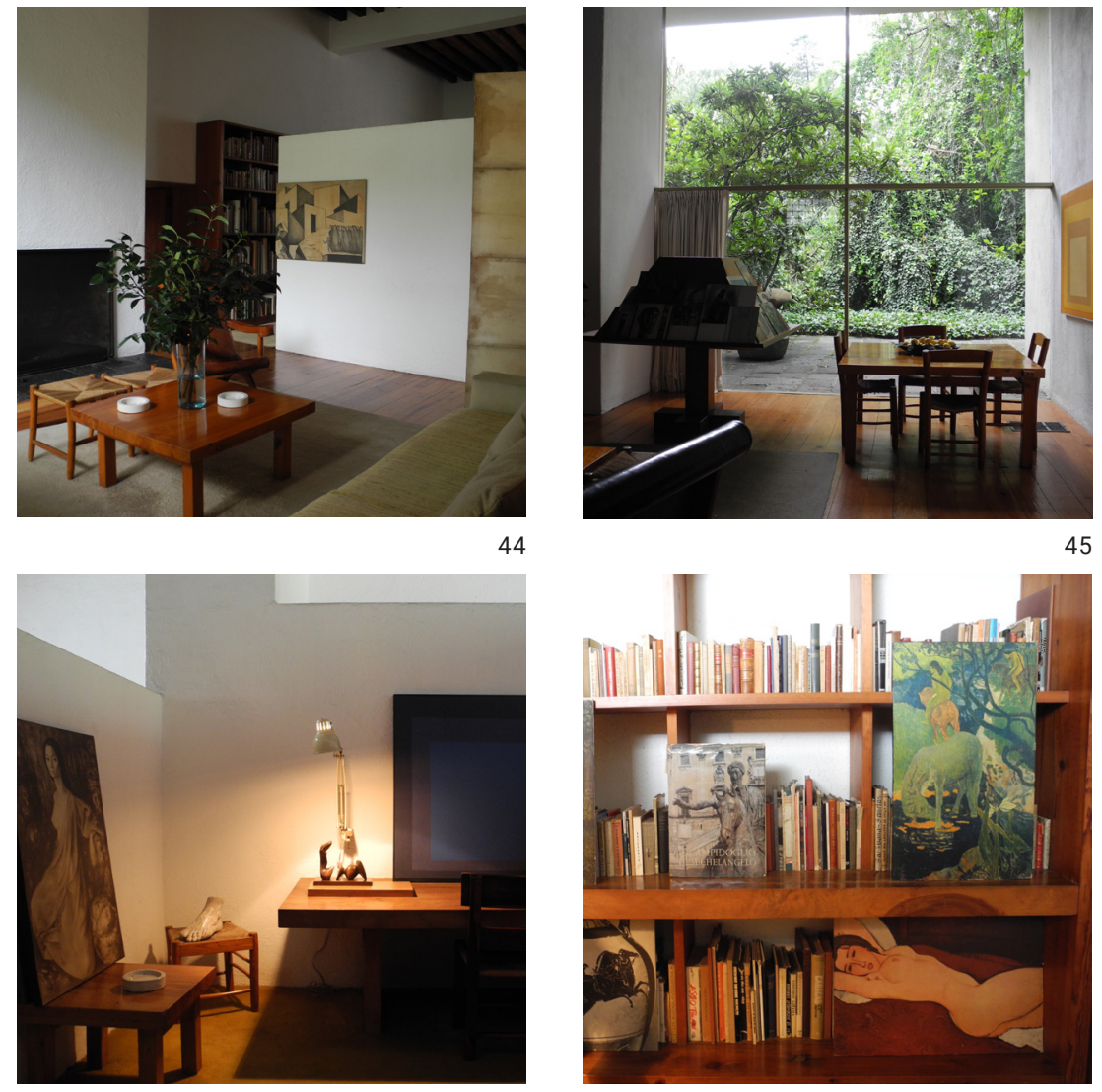

47
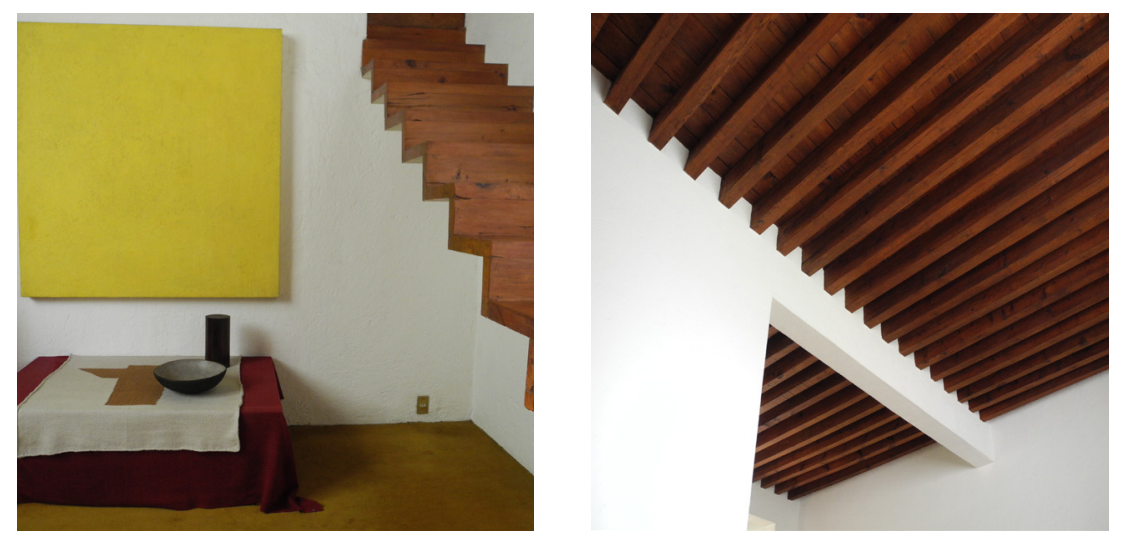

51

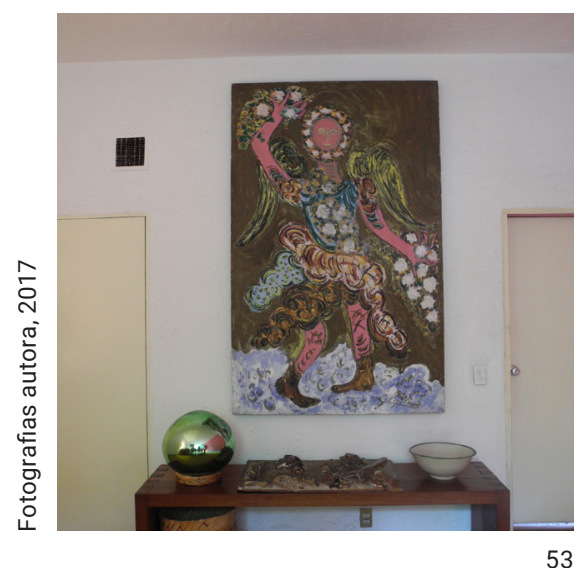

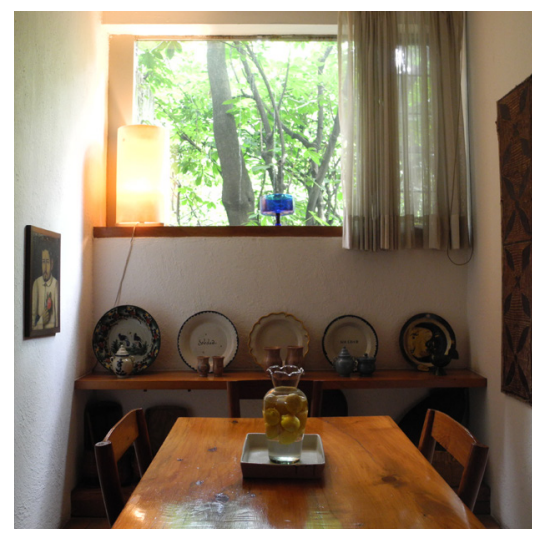

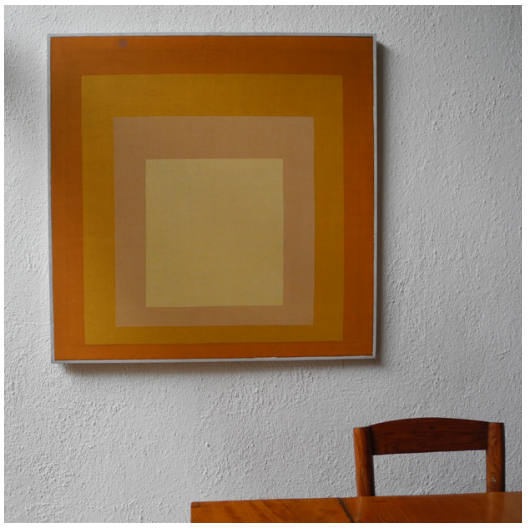

46

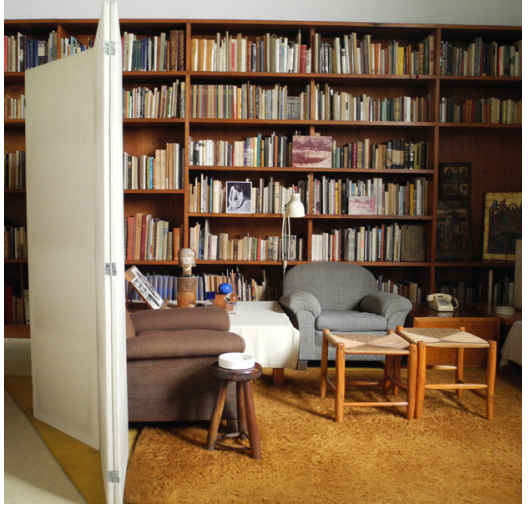

49

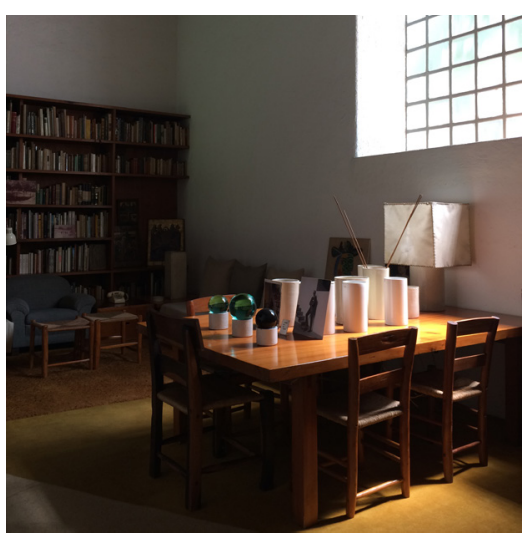

52

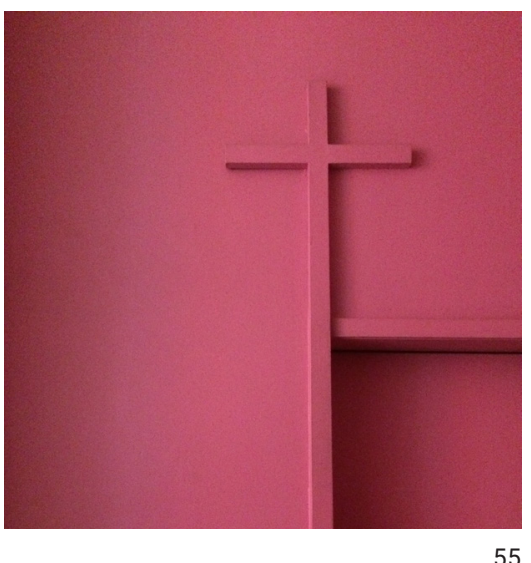



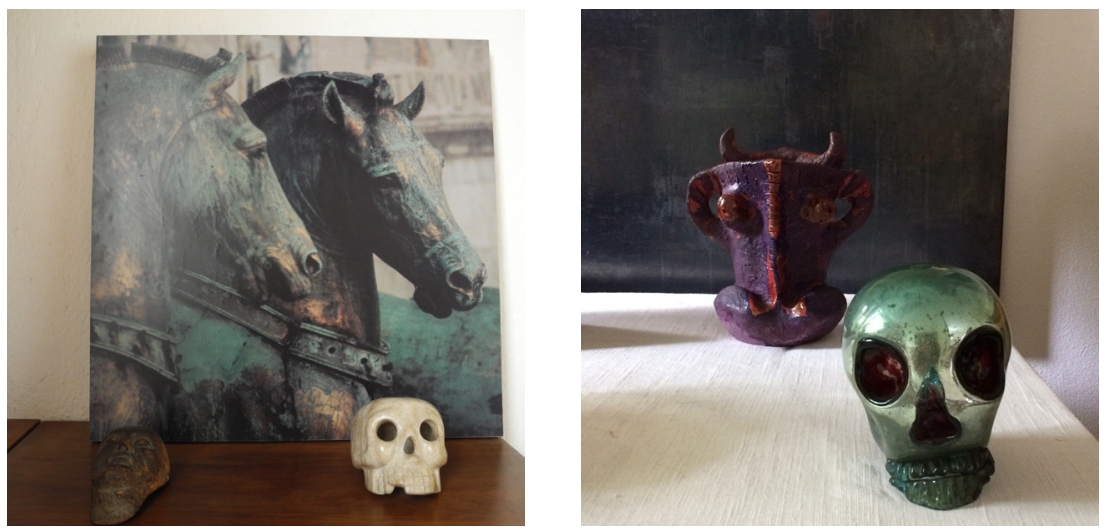

56

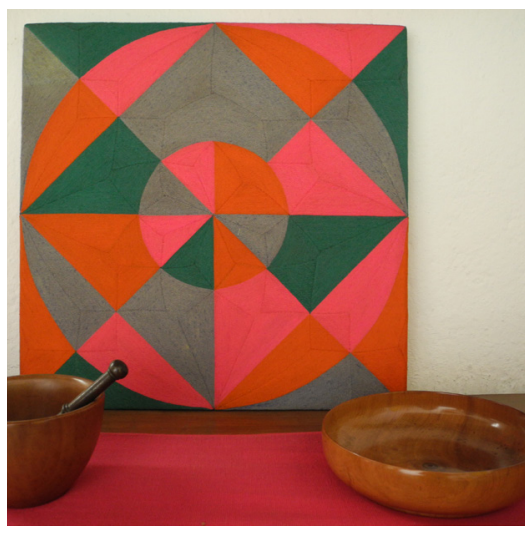

59
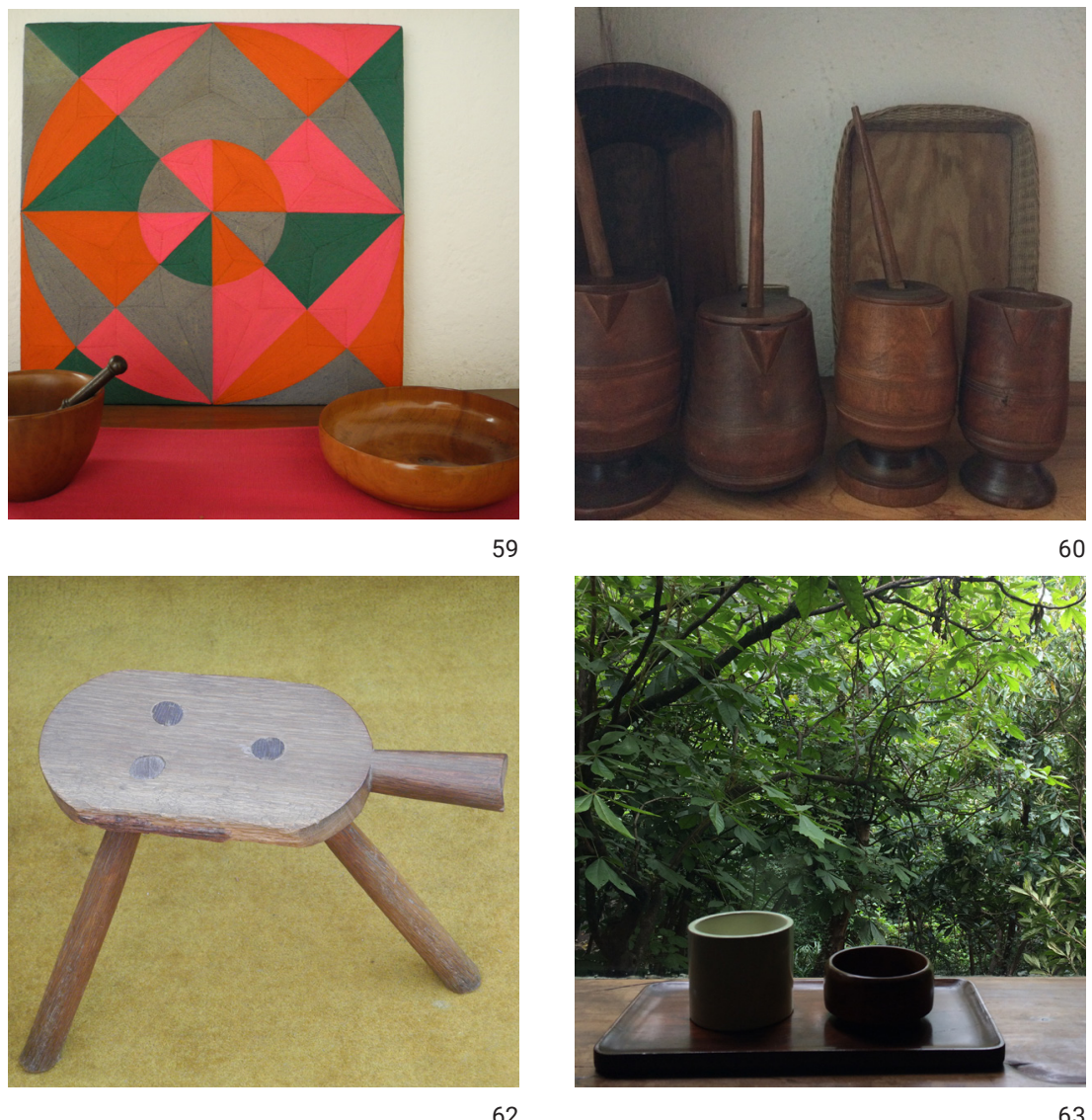

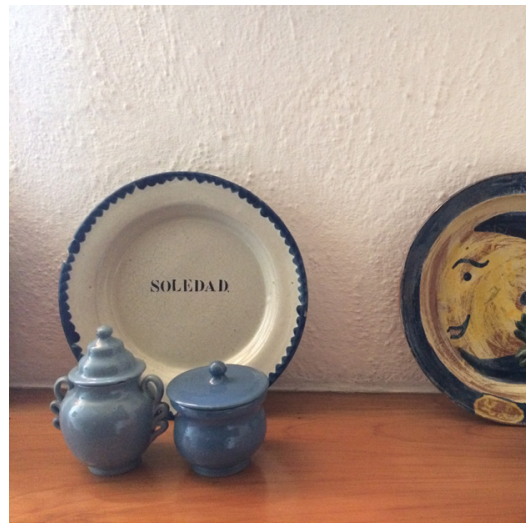

58

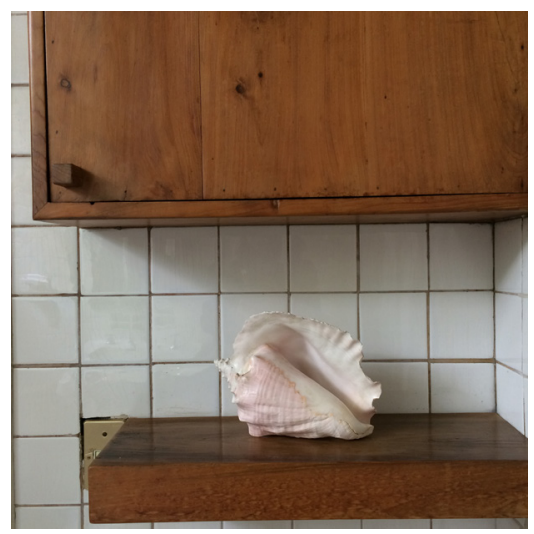

61

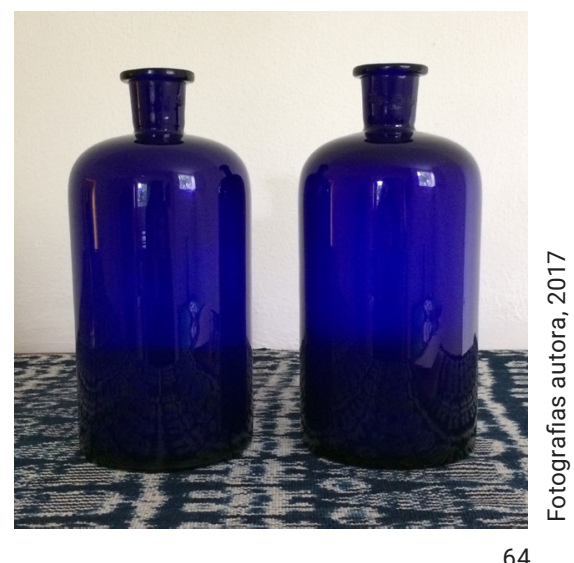




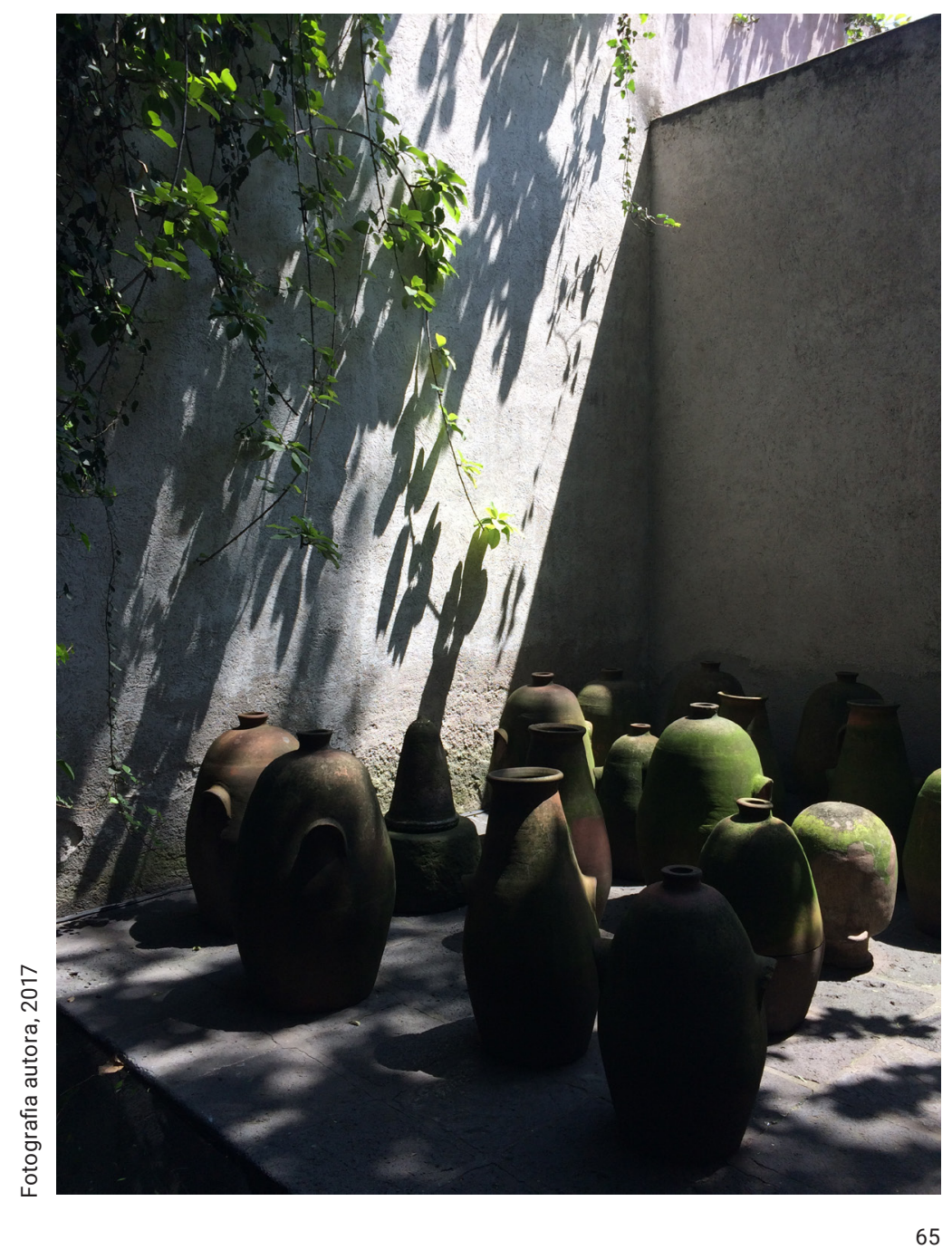




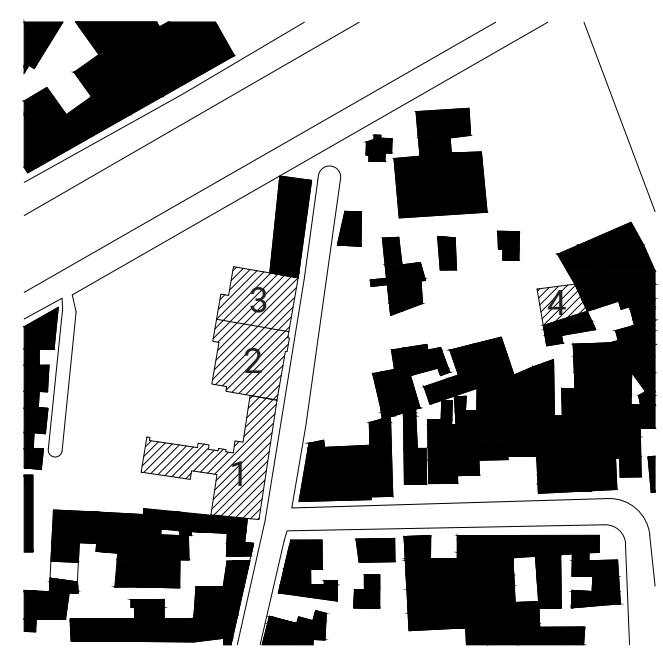

1. Casa Ortega

2. Casa Barragán

3. Estúdio Barragán

4. Anexo Ateliê Barragán 


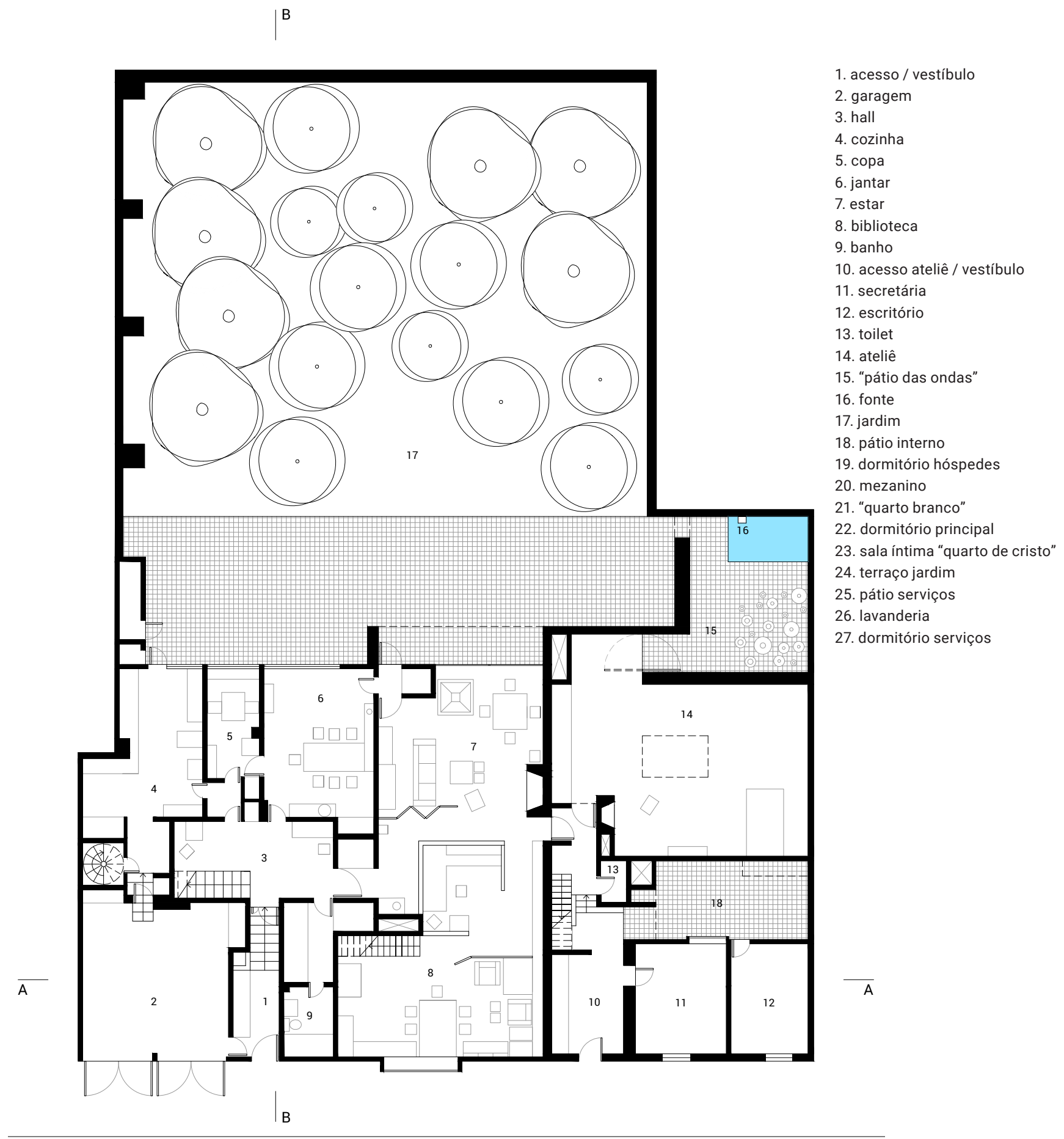

Rua Francisco Ramírez

planta térreo

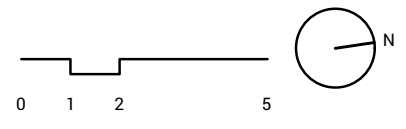





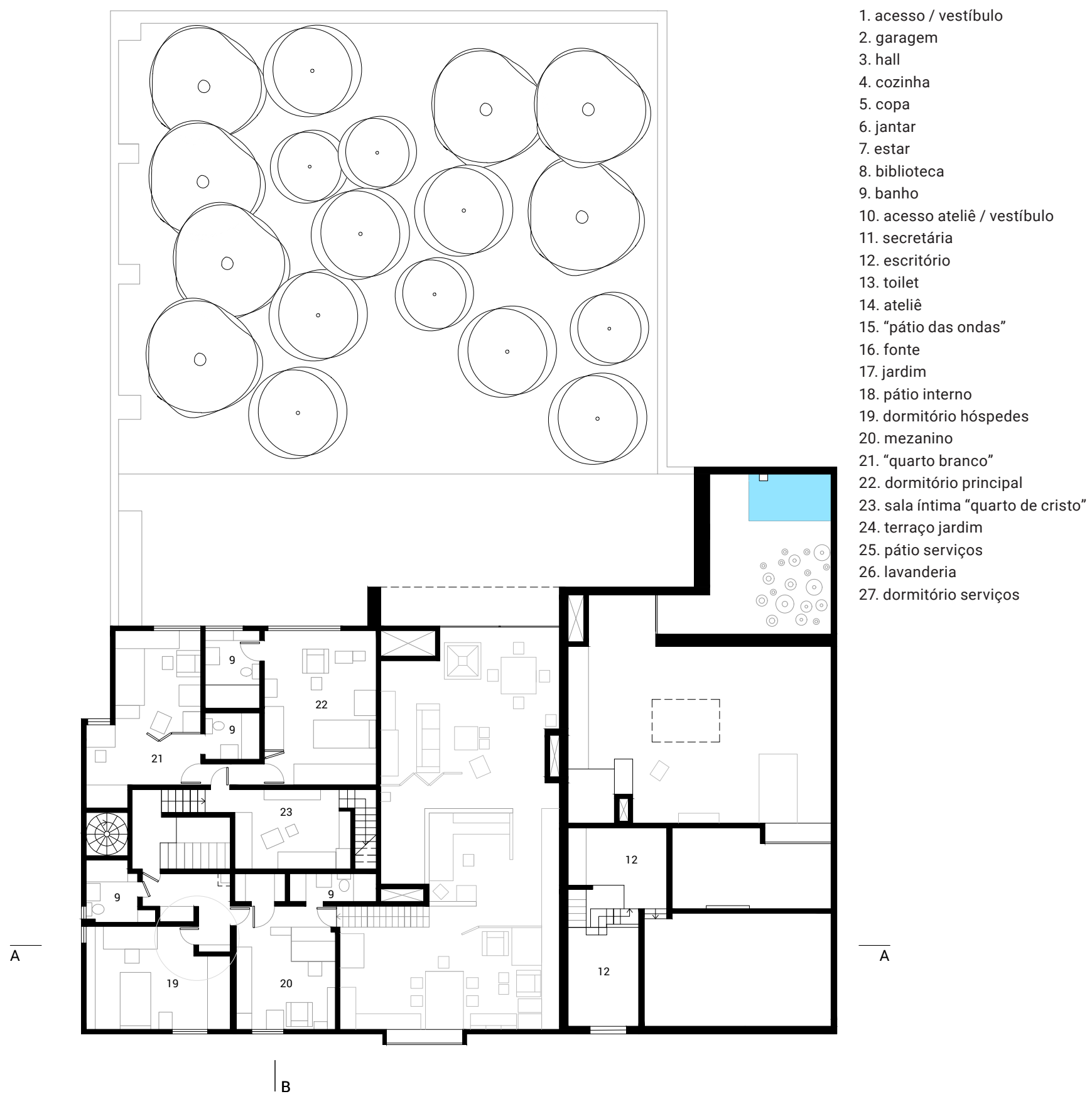

planta pavimento superior

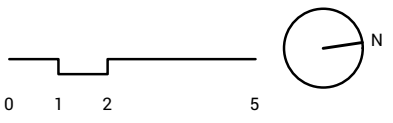





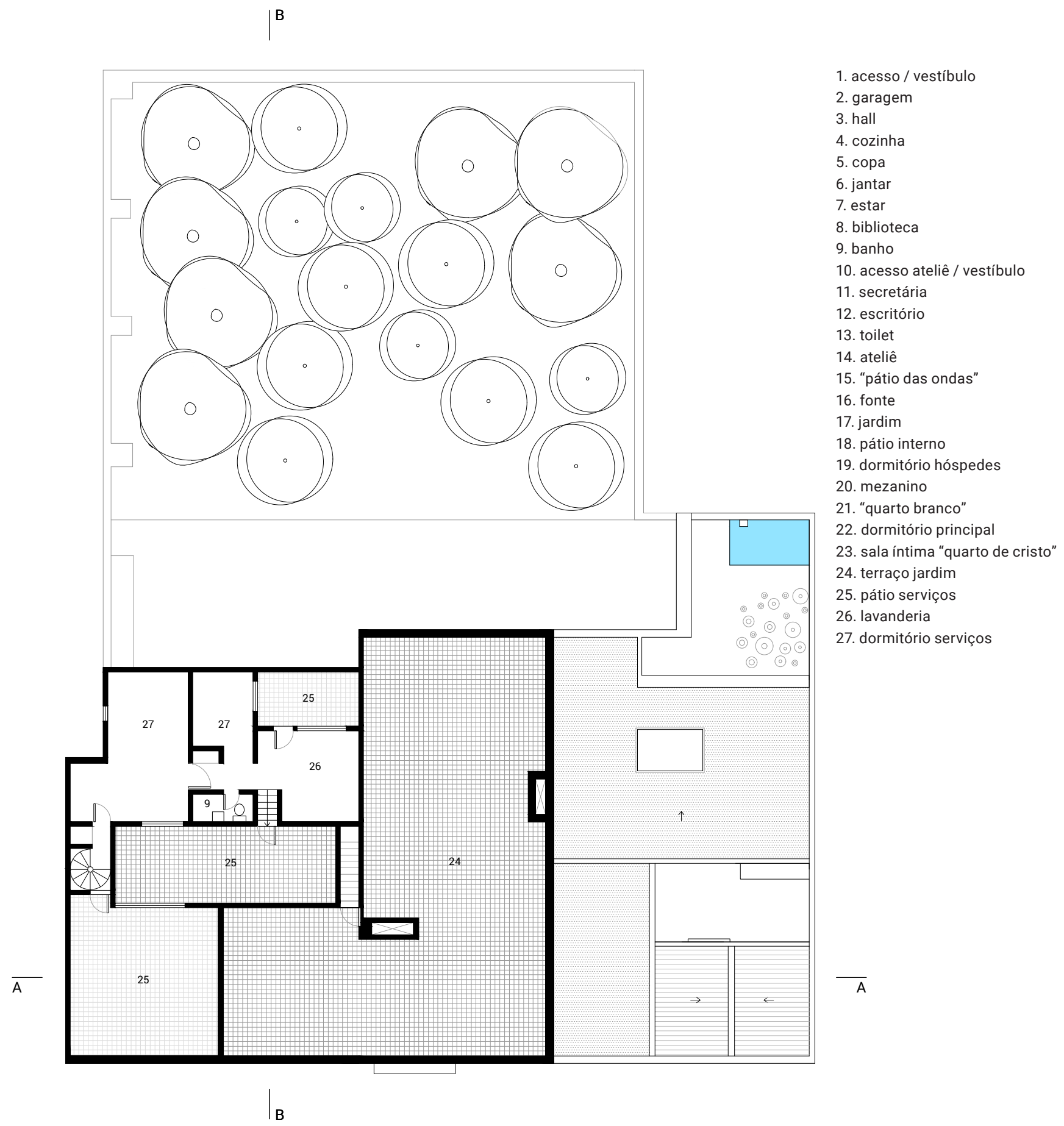

planta cobertura 



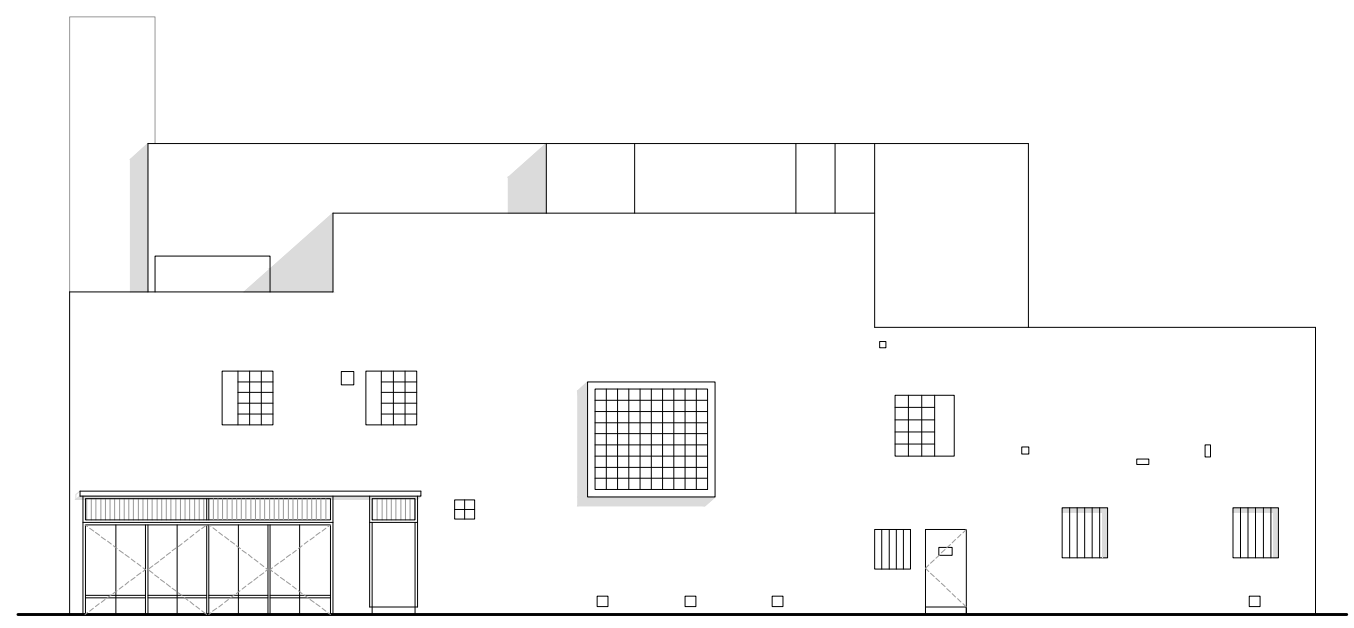

fachada leste

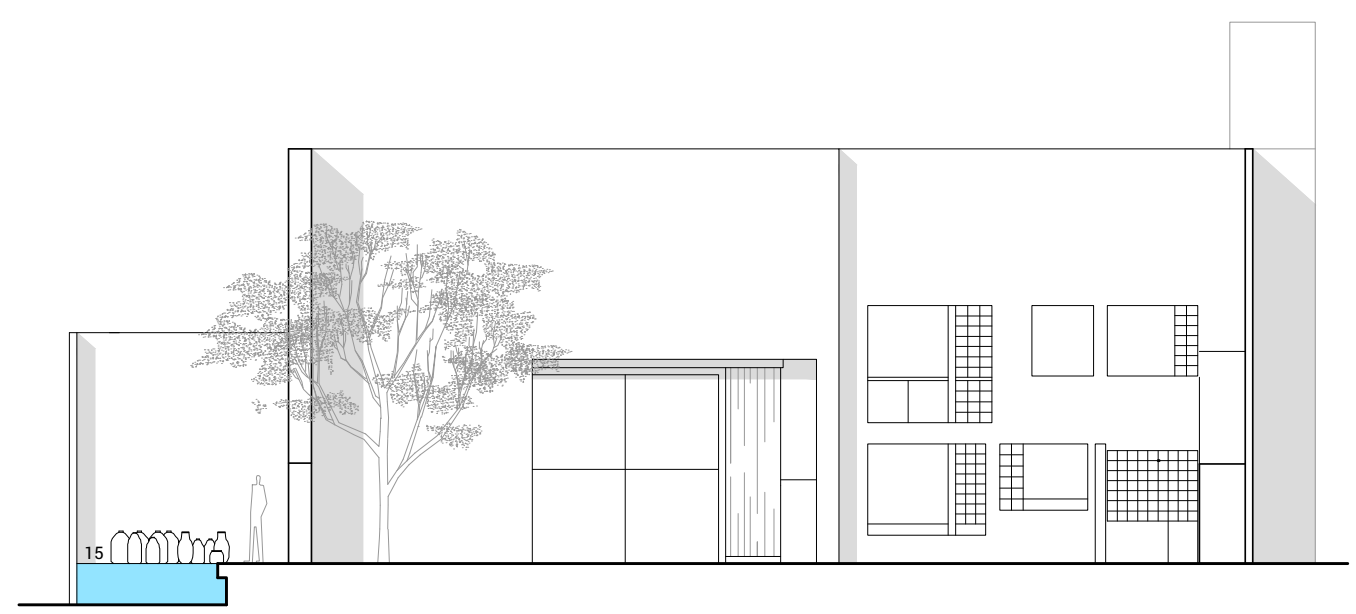

fachada oeste

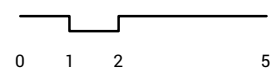





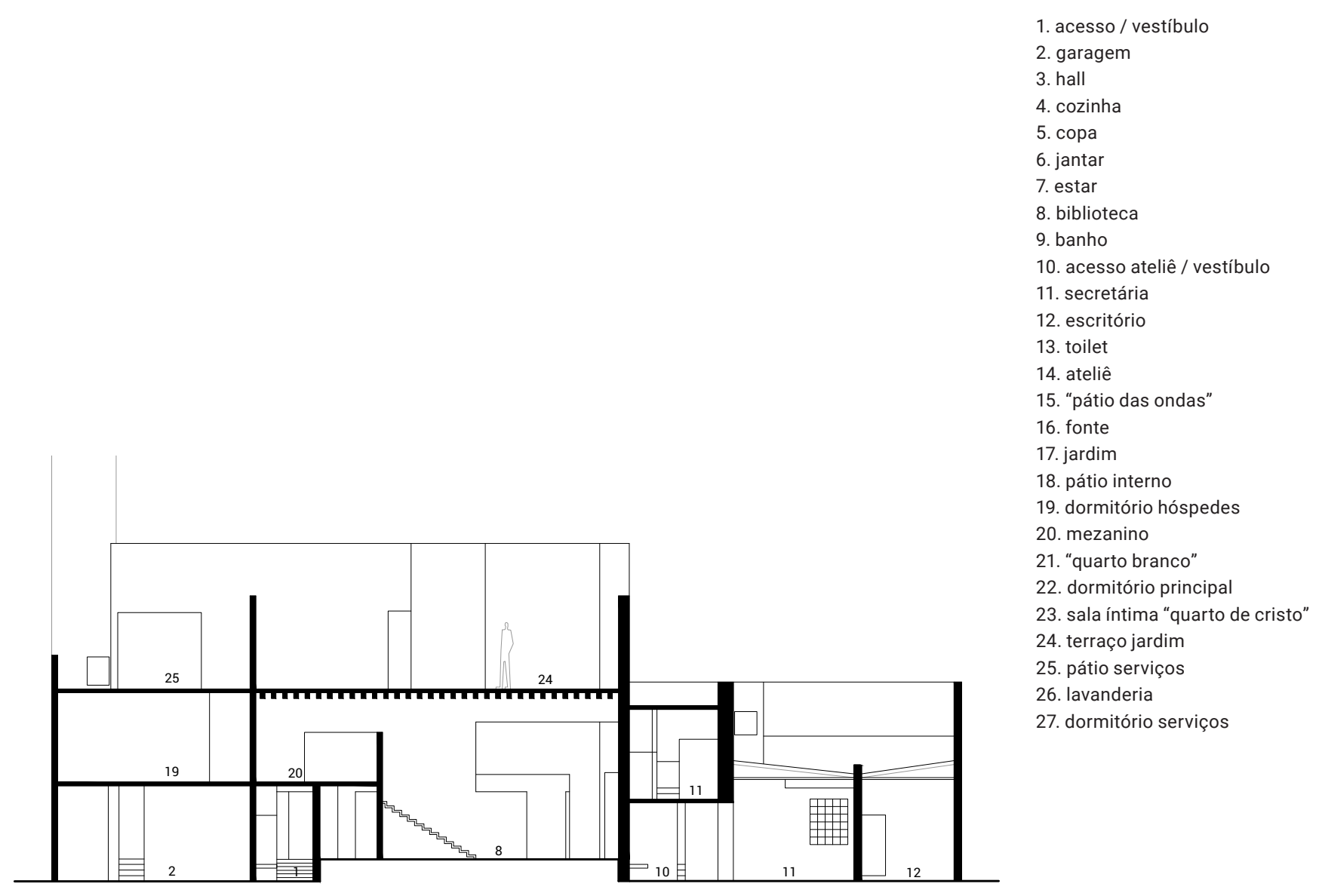

corte A

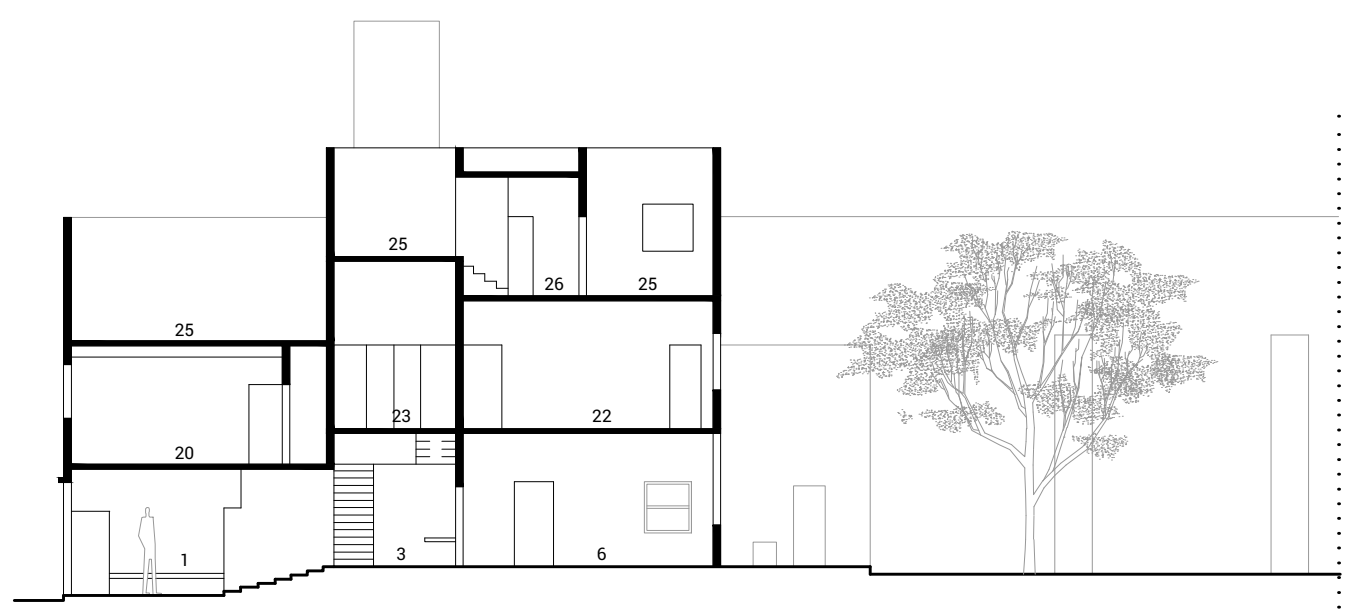

corte B

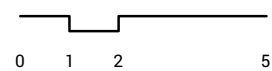





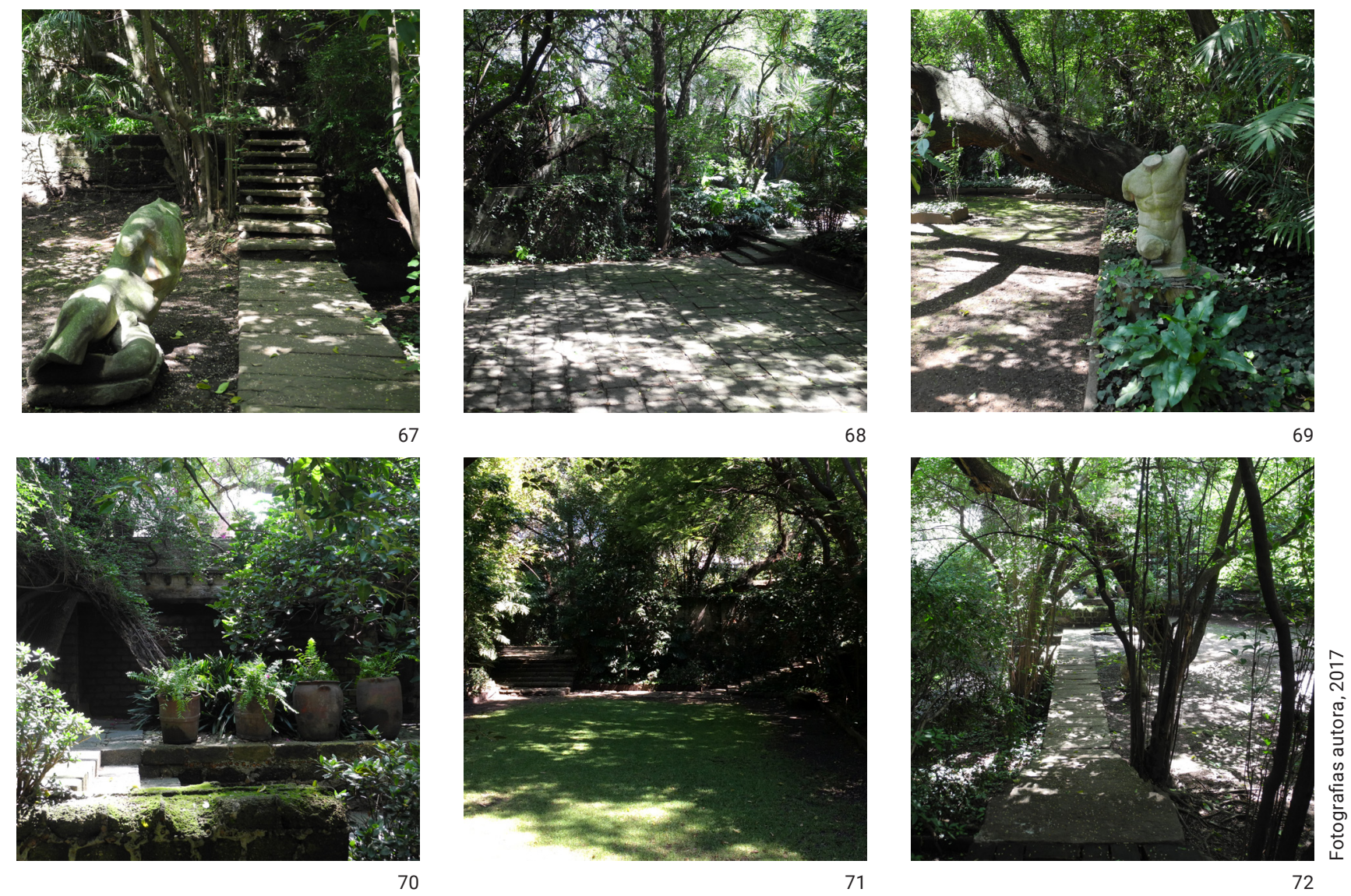

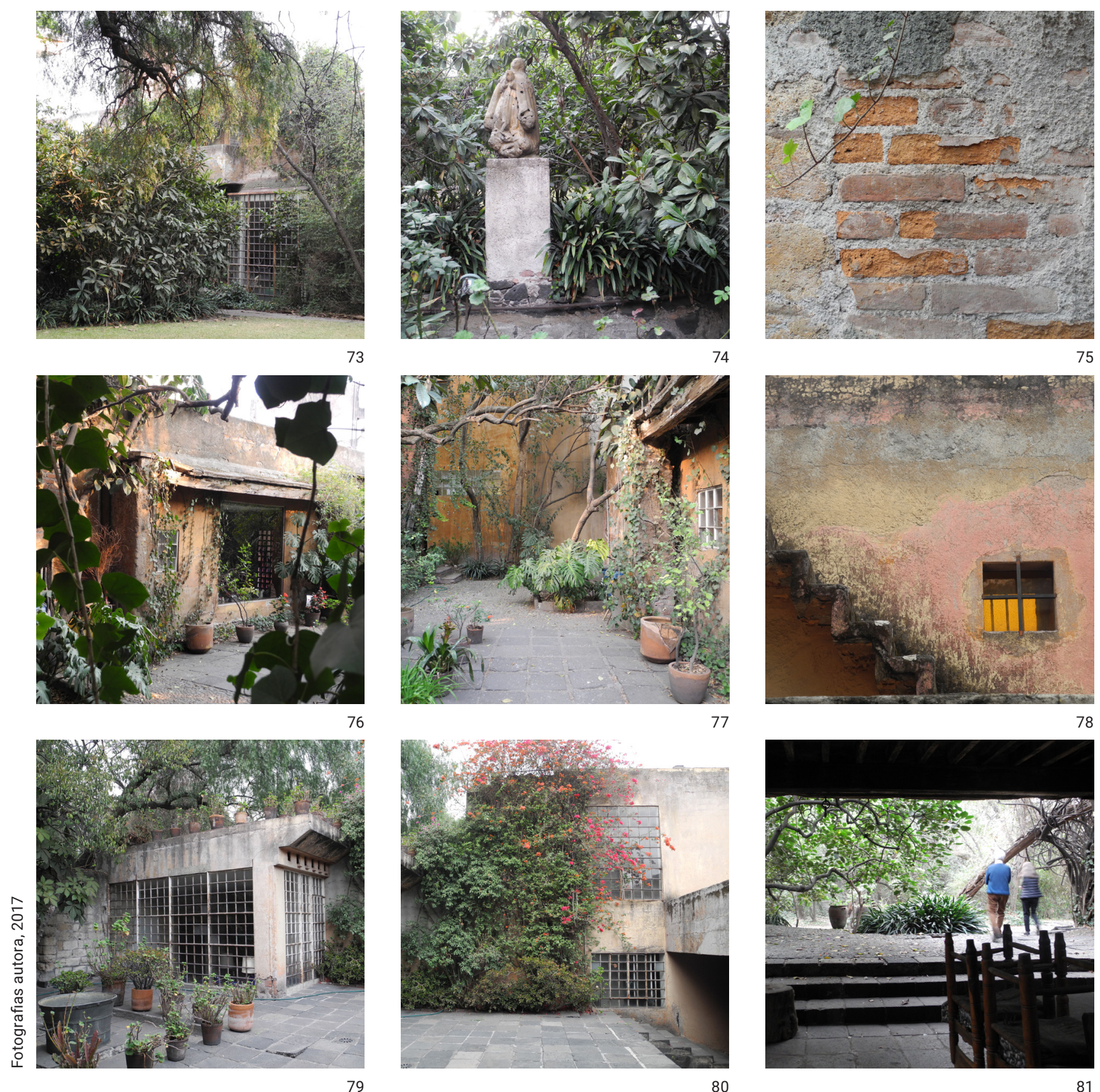

81 


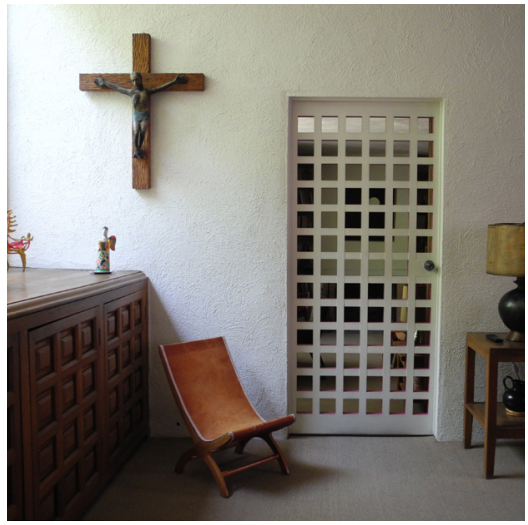

82

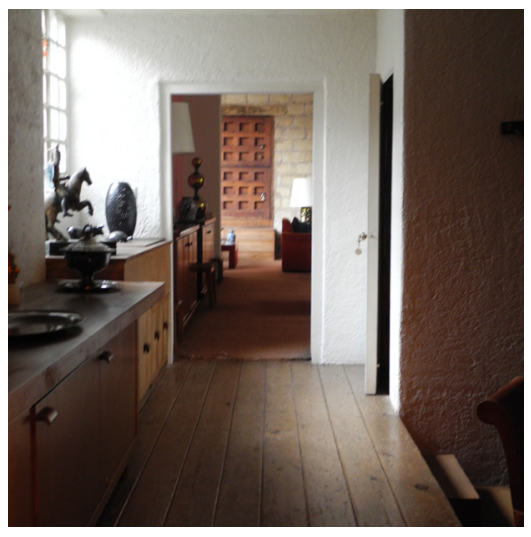

85

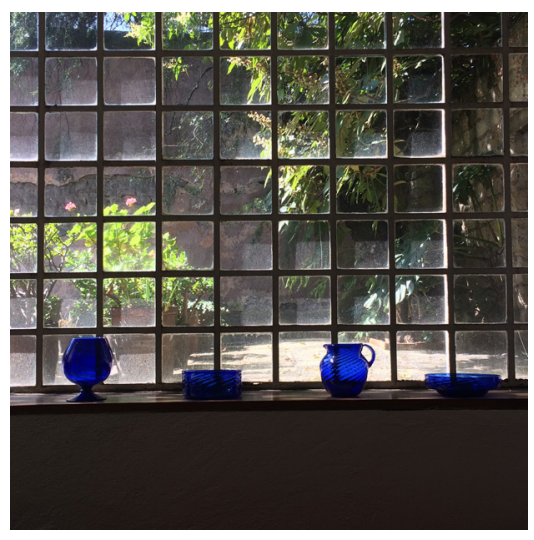

88

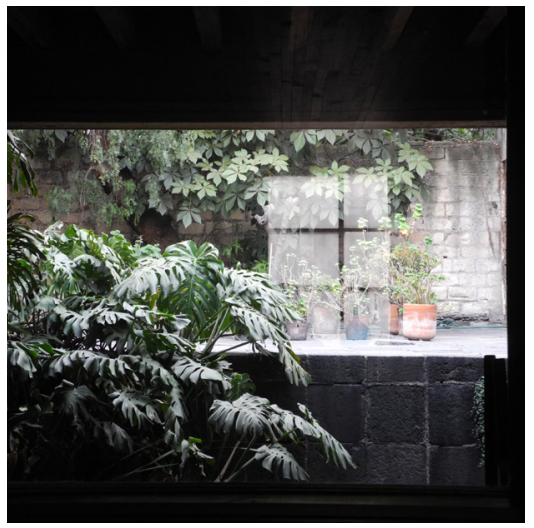

83

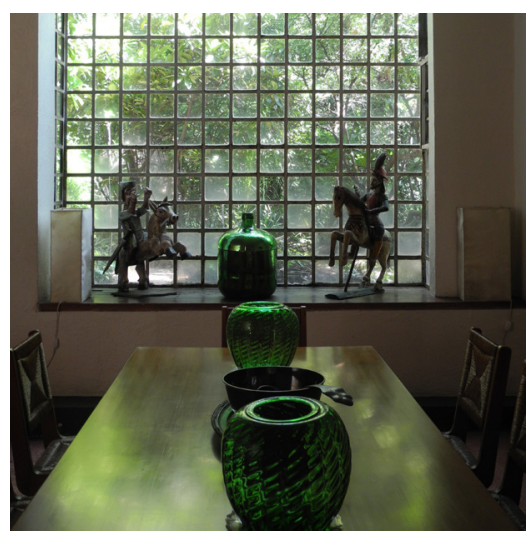

86

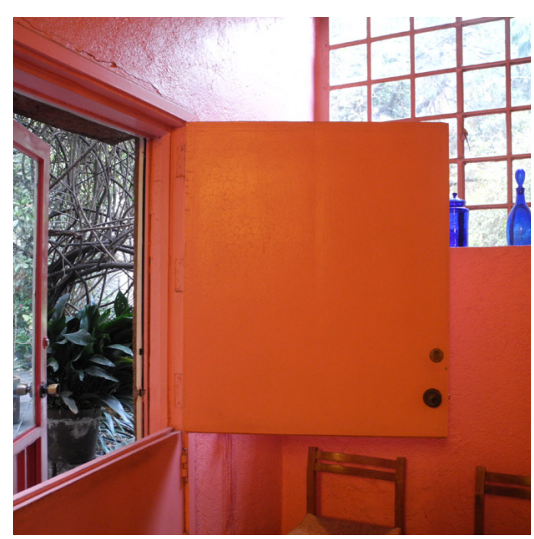

89

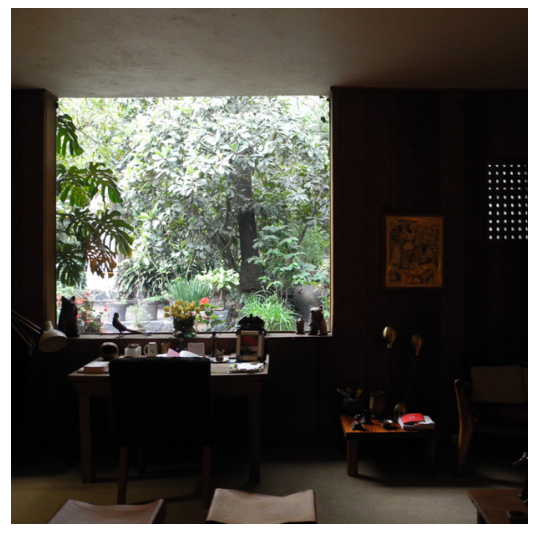

84

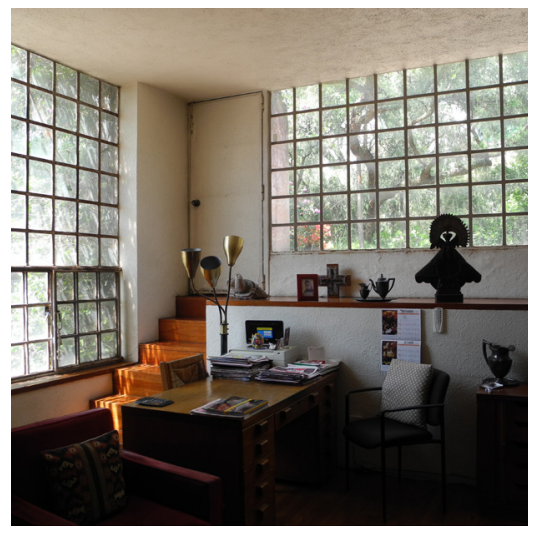

87

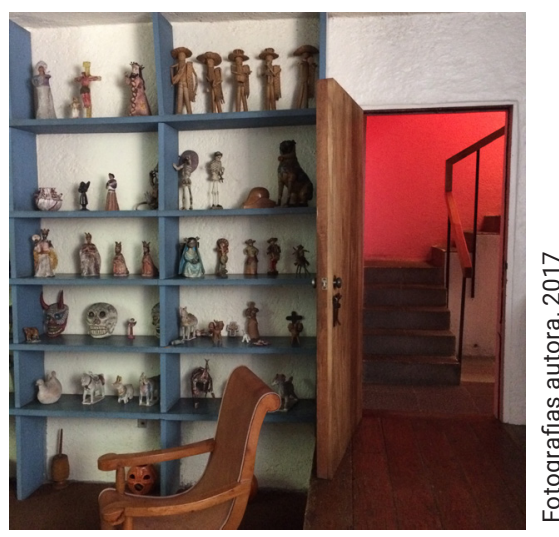

90 


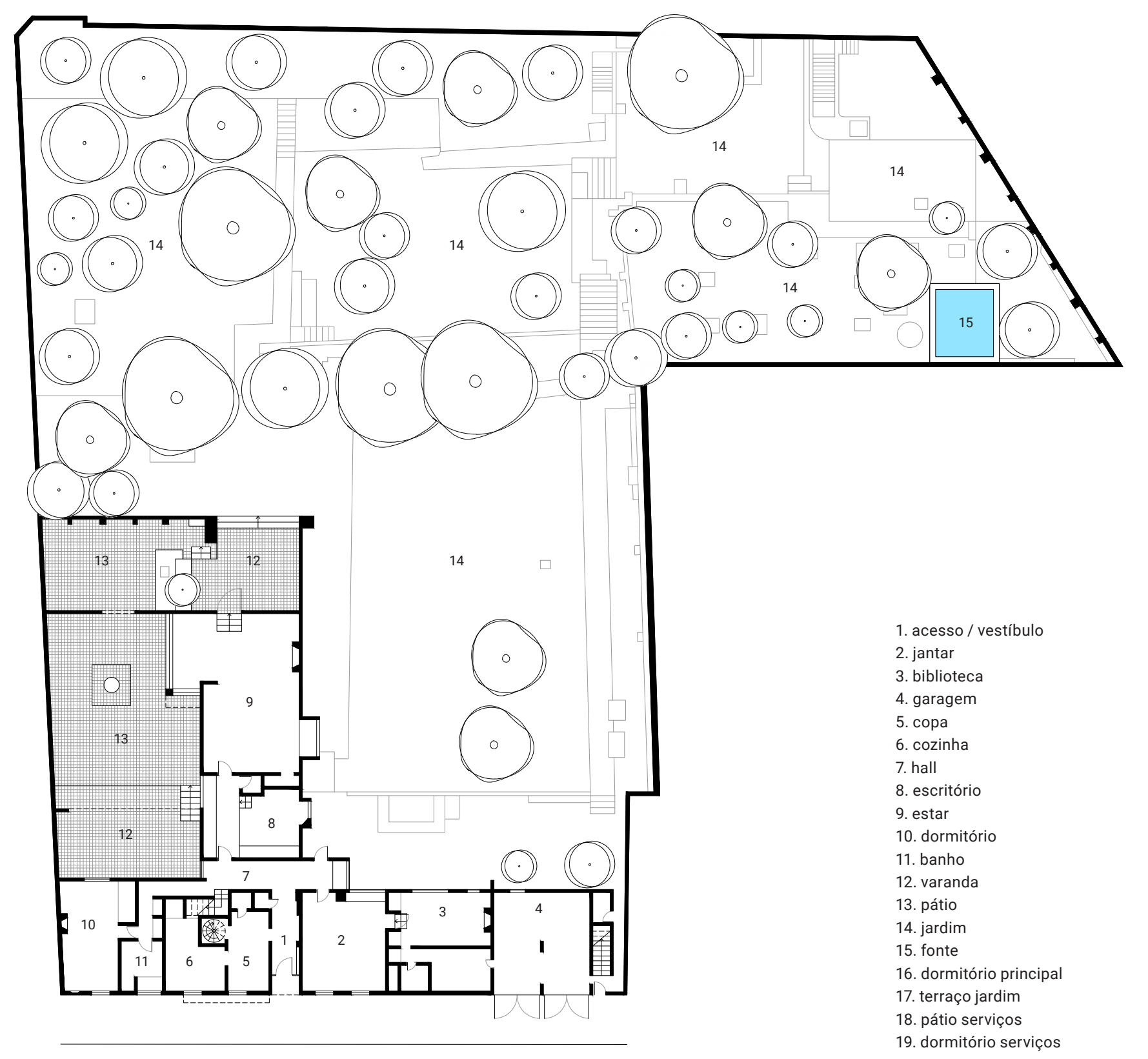

Rua Francisco Ramírez

planta térreo

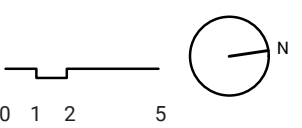





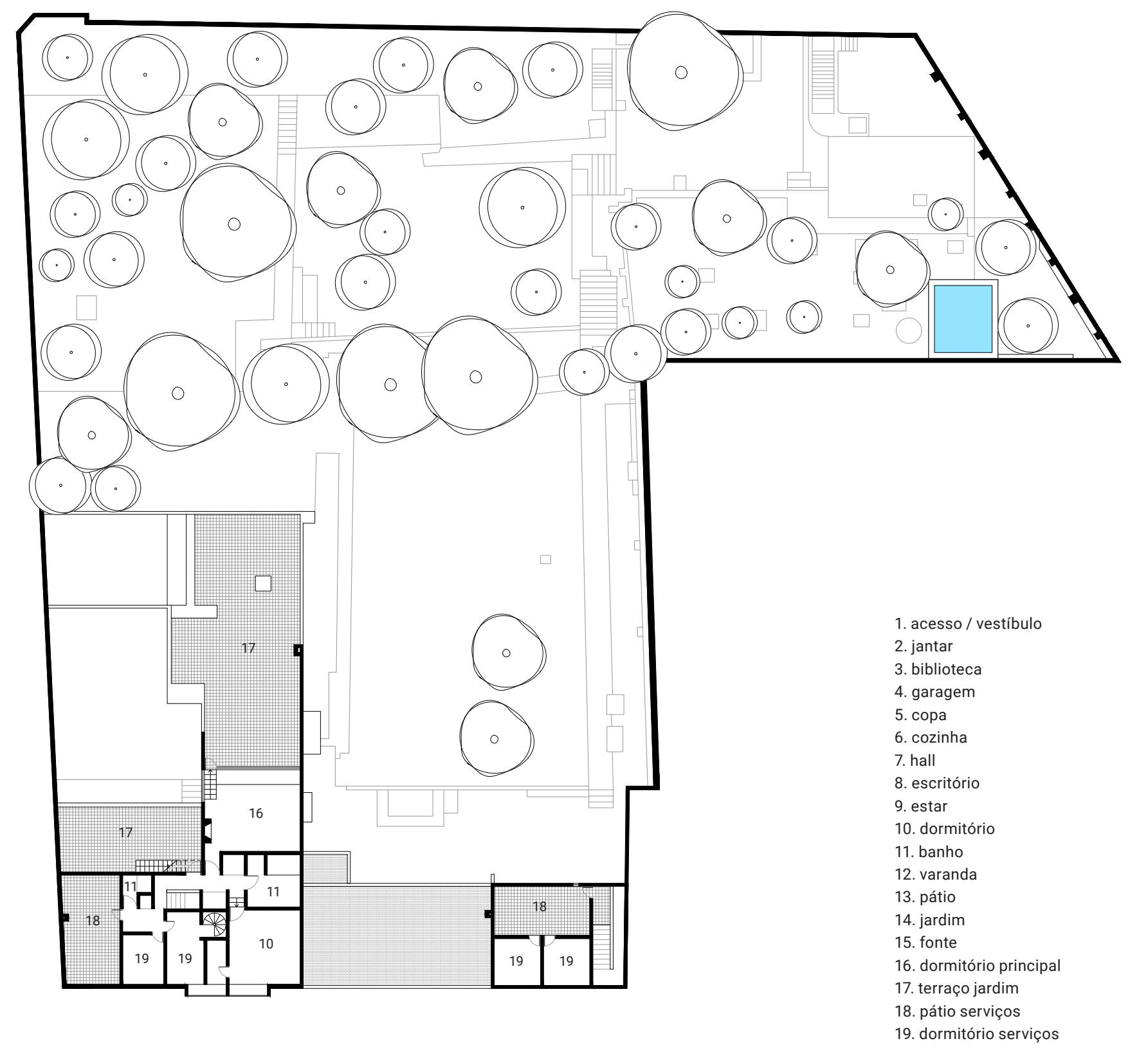

planta pavimento superior

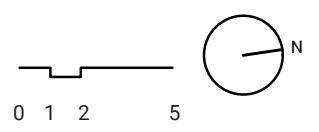





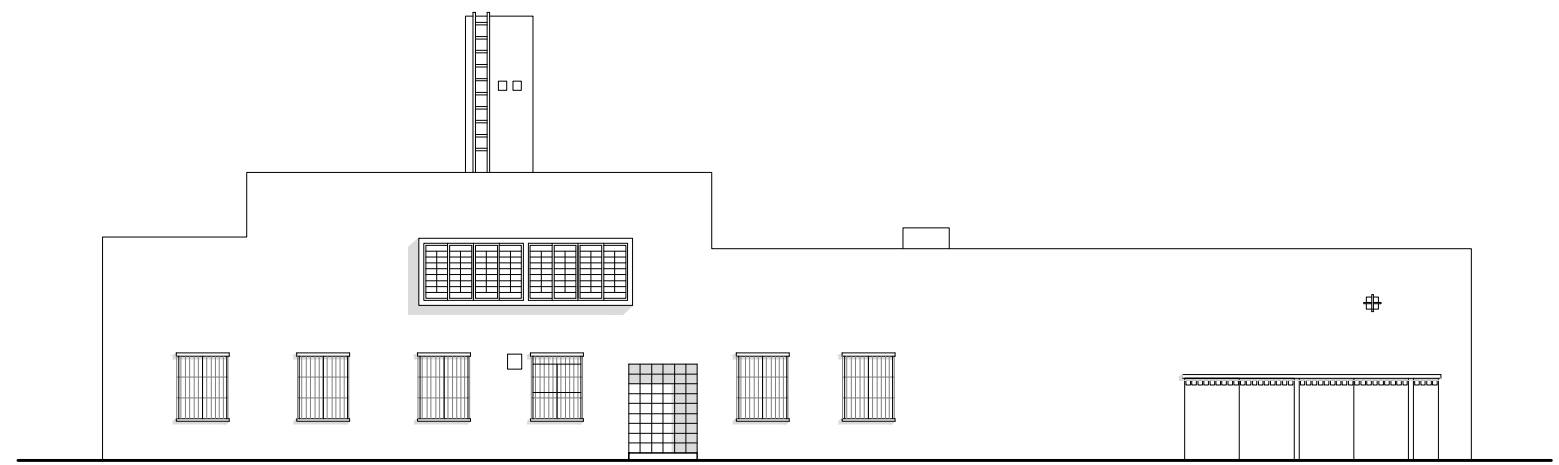

fachada leste

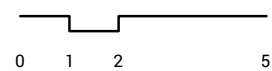





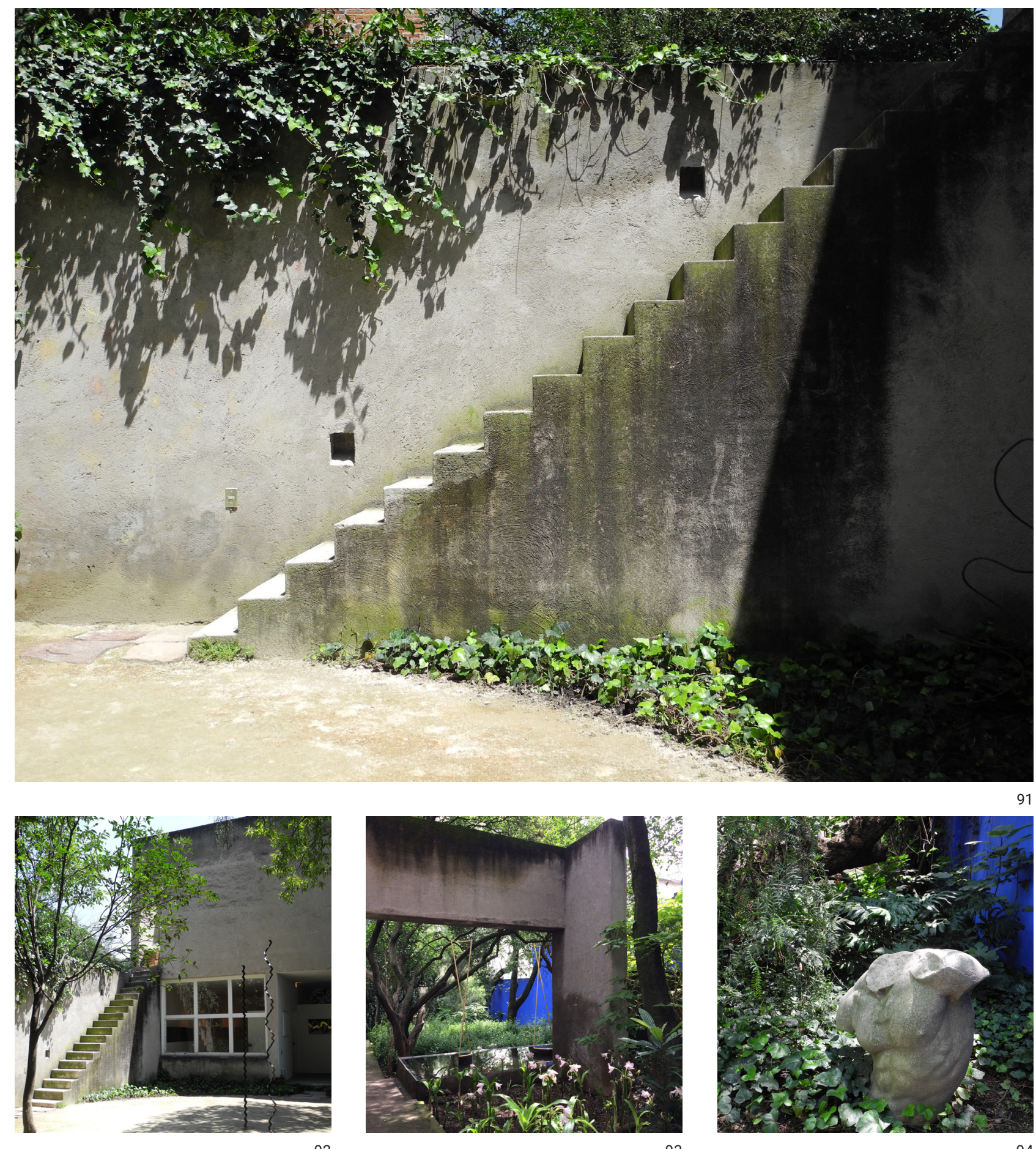

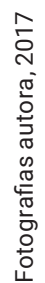




\subsection{Viagem ao Norte da África}

Outro momento chave na vida de Luis Barragán é a viagem para o Norte da África que Barragán realiza entre 1952 e 1953. Iniciando a viagem pela Europa, Barragán vai para Marrocos e se diz impressionado com as construções e cultura local. As "casbahs", ou cidadelas, construções características do Norte da África, conformam-se por altos muros de adobe. Essa arquitetura feita a partir de materiais existentes camufla-se na paisagem conformando uma única paisagem. Mas não apenas as construções chamaram à atenção de Barragán, também o misticismo, as danças, as roupas, e toda atmosfera envolvida nas "casbahs". De um lado o interesse em sua materialidade e de outro, em suas crenças e, sobretudo, como ambas relacionam-se. Alfonso Alfaro estudou cuidadosamente a biblioteca de Barragán, o resultado foi a publicação "Voces de tinta dormida: itinerários espirituales de Luis Barragán" (1996), nela Alfaro afirma que foram os livros sobre as caravanas beduínas que fizeram Barragán atravessar o deserto do Sahara. Desta viagem, se vê presente nas obras de Barragán o uso de objetos de arte da cultura africana. Logo após o retorno ao México, Barragán inicia o projeto da Capela e Ampliação do Convento de Tlalpan.

Un viaje que hice al África ha sido el viaje que más me ha impresionado en mi vida, es donde vi las construcciones que se llaman "casbahs", en el norte del desierto del Sahara, al sur de Marruecos. Es lo que encontré plásticamente más ligado al paisaje, más ligado a la gente que lo vive, a su ropa, al ambiente de la atmósfera, inclusive más ligado a sus propias danzas, a su familia; es decir encontré ahí la integración perfecta de su religión con todo el ambiente en que viven y las cosas físicas que tocan. (BARRAGÁN, 1962, p. 87 e 88$)^{17}$

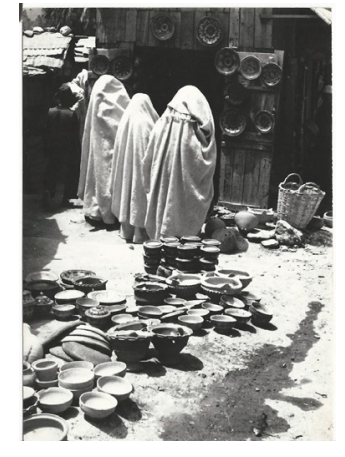

95

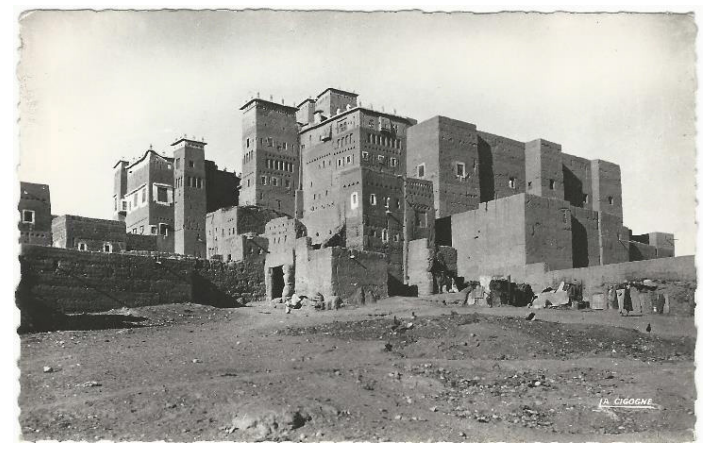

96

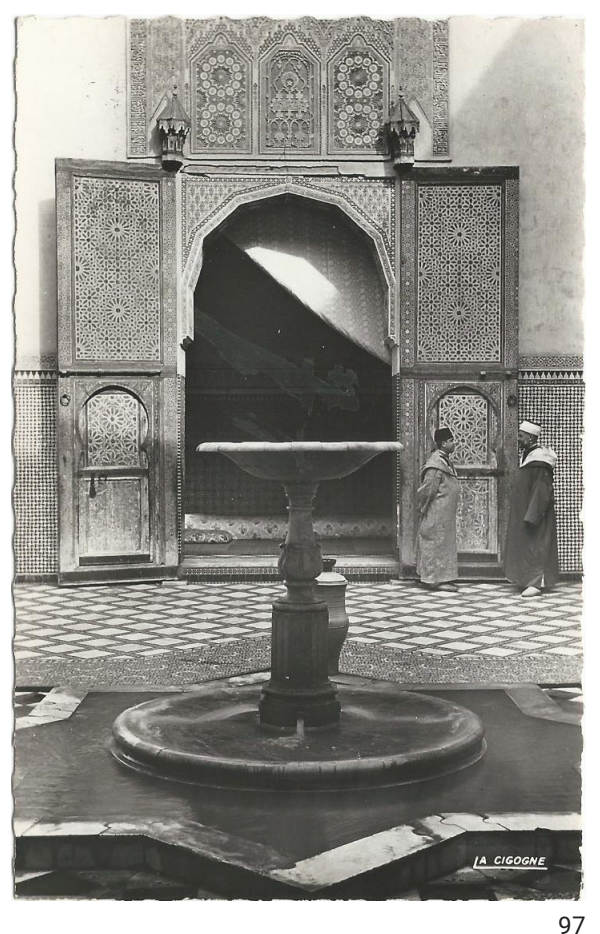

17. "Uma viagem que fiz à África foi a viagem que mais me impressionou na vida. Foi onde vi as construções que se chamam "casbahs", no norte do deserto Sahara, ao sul de Marrocos. É o que encontrei plasticamente mais ligado à paisagem, mais ligado às pessoas que a vivem, à sua roupa, ao ambiente da atmosfera, inclusive mais ligado à suas próprias danças, à sua família; assim dizendo, encontrei lá a integração perfeita de sua religião com todo o ambiente em que vivem e as coisas físicas que tocam". (BARRAGÁN, 1962, p.87 e 88, tradução da autora). 
En mi proyecto para la capilla de las Capuchinas Sacramentarias del Purísimo Corazón de María, estudié atentamente luces y colores, porque quería crear una atmósfera de quietud y reflexión espiritual. La idea de penumbra era muy importante en ese proyecto. (BARRAGÁN, 1981, p. 129) ${ }^{18}$
O que era para ser um projeto de pequenas reformas e melhorias em um convento existente no bairro de Tlalpan, acabou tornando-se uma das principais obras de Luis Barragán. Localizado na Rua Miguel Hidalgo, no número 43, no antigo bairro de traçado ortogonal do período colonial e conformado por construções do século XVII, ao sul da Cidade do México, a construção da capela e ampliação do Convento de Tlalpan fez-se em duas fases. Por sua ideologia religiosa, o projeto e obra foram totalmente financiados e realizados pelo próprio Barragán. 0 projeto constitui-se de três etapas: reorganização do convento existente; construção da capela e a reestruturação e extensão do claustro. Para este projeto, Barragán consultou o pintor Jesús "Chucho" Reyes, e os historiadores Justino Fernández e Edmundo O'Gorman (FERREIRA, 1980, p. 10) e conformou uma equipe específica para a realização do conjunto arquitetônico, incluindo arquitetos, artistas, engenheiros, mestre de obra, e carpinteiros. Os engenheiros Pablo González López e José Creixell fizeram os cálculos estruturais, e o artista Mathias Goeritz foi responsável pelo vitral na capela. Segundo texto de Raúl Ferreira ${ }^{19}$ de 1980 o método de trabalho do arquiteto mexicano era o de fazer e refazer até encontrar a solução que melhor Ihe agradava:

Luis Barragán diseñaba y decidía. Si al ejecutarlo no le gustaba, se demolía y se volvía a construir, hasta que quedó como se encuentra ahora: de una absoluta simplicidad. (FERREIRA, 1980, p. 12$)^{20}$
18. “Em meu projeto para a capela das Capuchinas Sacramentárias do Puríssimo Coração de Maria, estudei atentamente a luz e cores, porque queria criar uma atmosfera de quietude $e$ reflexão espiritual. A ideia de penumbra era muito

importante neste projeto". (BARRAGÁN, 1981, p. 129 , tradução da autora).

19. O engenheiro Raúl Ferreira (1942-1992) foi sócio de Luis Barragán por 16 anos, iniciando a colaboração com o arquiteto mexicano em

1964. O texto de Raúl

Ferreira sobre a Capela e Convento de Tlalpan está publicado em uma edição especial publicada pela Barragan Foundation em 2005. A publicação leva mesmo título da obra e contém fotografias de Armando Salas Portugal.

20. "Luis Barragán desenhava e decidia. Se quando executado não gostava, derrubava e construía de novo, até chegar como se encontra agora: de uma absoluta simplicidade". (FERREIRA, 1980, p. 12, tradução da autora).

21. Entrevista realizada pela autora com Martin Luque em fevereiro de 2016.

Martin Luque, atual morador da Casa Gilardi, 1975-1977, confirma o mesmo processo ${ }^{21}$. Ocorre também na Casa Estúdio em Tacubaya, que era de fato seu laboratório de experimentação. Como as casas em Tacubaya, o convento visto de fora se passa despercebido, é anônimo. Barragán reconfigura novos ambientes, através de elementos arquitetônicos, em um jogo de composição luz, sombra e reflexos, nova materialidade e cores simbólicas. 0 terreno alargado, que já conformava jardins existentes em seu interior, contempla agora uma série de espaços pensados em sequência e no percurso dentro do convento. Um novo pátio interno, por exemplo, possui o piso em pedra vulcânica, típica do lugar, uma cruz em relevo em um dos altos muros brancos que enquadram o pátio, um espelho d’água negro, no qual a água escorre pelos três lados do tanque refletindo um muro de elemento vazado de cor amarela, separando o acesso à Capela. Esse pátio separa a área pública do convento e a área privativa do claustro, e também afasta a vida lá fora. Barragán configura em diversos momentos deste projeto esses 
espaços de transição, induzindo o visitante a certa introspecção. No interior da Capela, a entrada de luz é controlada por precisas aberturas, o vitral na cor âmbar de Mathias Goeritz reflete tons amarelados e toda a Capela possui uma atmosfera específica com variação cromática devido aos tons alaranjados das paredes. A Capela é livre de adornos, e ao mesmo tempo em que mantém simplicidade em sua composição sugere amplitude. A riqueza está na materialidade e na luz. A planta da Capela é irregular, um prisma triangular recorta o ambiente em sua lateral, orientando a vista e a luz para o altar (ZANCO, 2011, p. 138). Todos os elementos arquitetônicos foram desenhados por Barragán: bancos de madeira, o altar de concreto, o tríptico composto por elementos quadrados recobertos com folhas de ouro, a cruz de madeira colocada entre o altar e a lateral da Capela e pintada da mesma cor da parede reflete sua sombra e reforça o valor simbólico.

É possível identificar no conjunto de obras da terceira fase a recorrência dos seguintes procedimentos: o desenho da luz, a presença da água, traços de Le Corbusier, a dimensão cromática, o uso de elementos vernáculos, a relação com a topografia nos projetos de Luis Barragán.

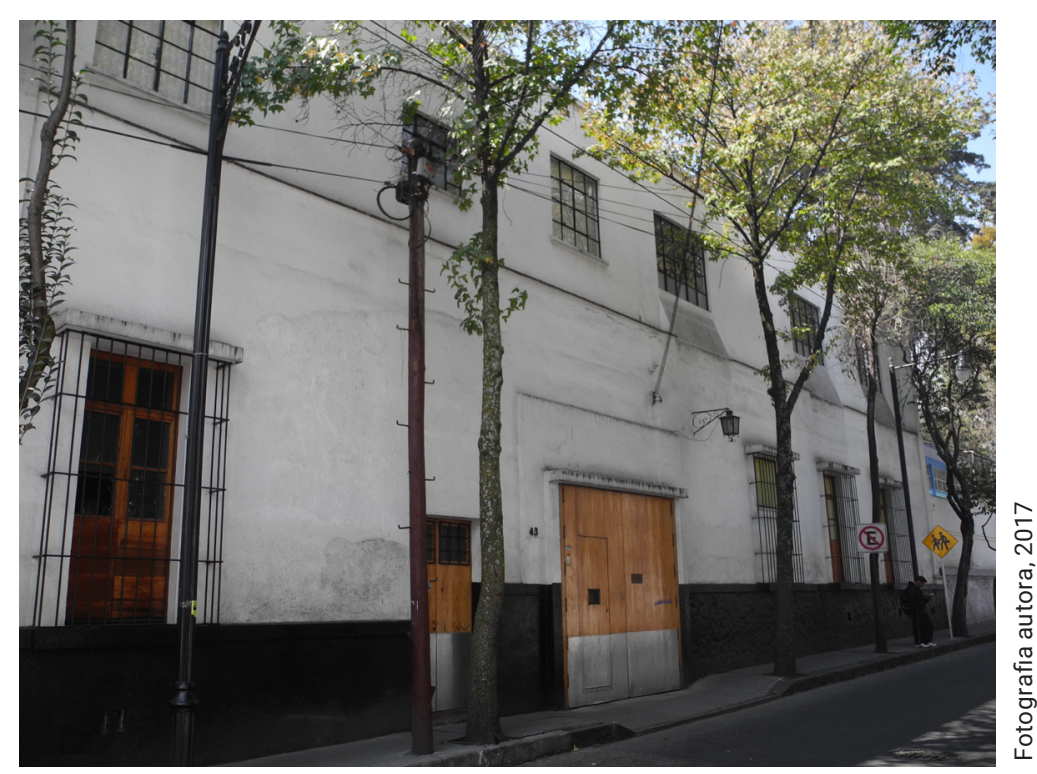

98

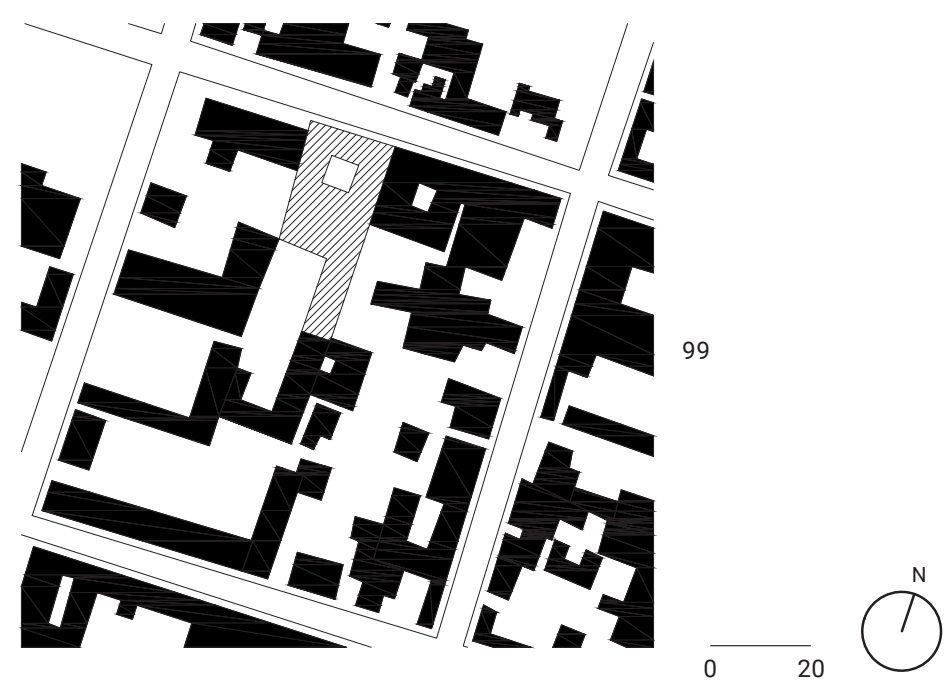





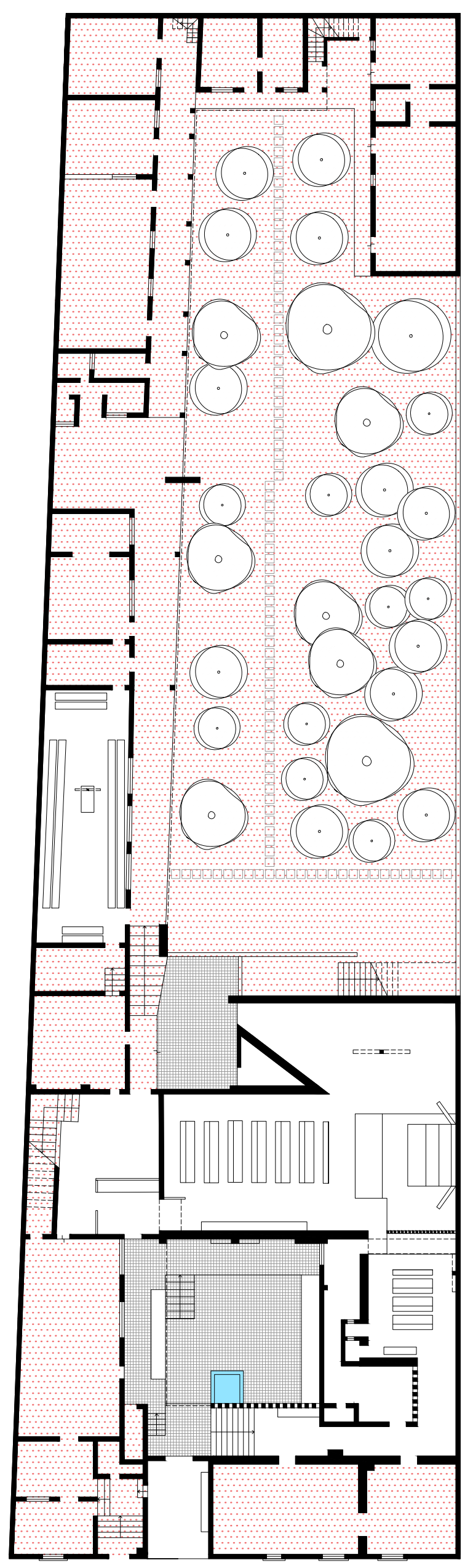

planta térreo

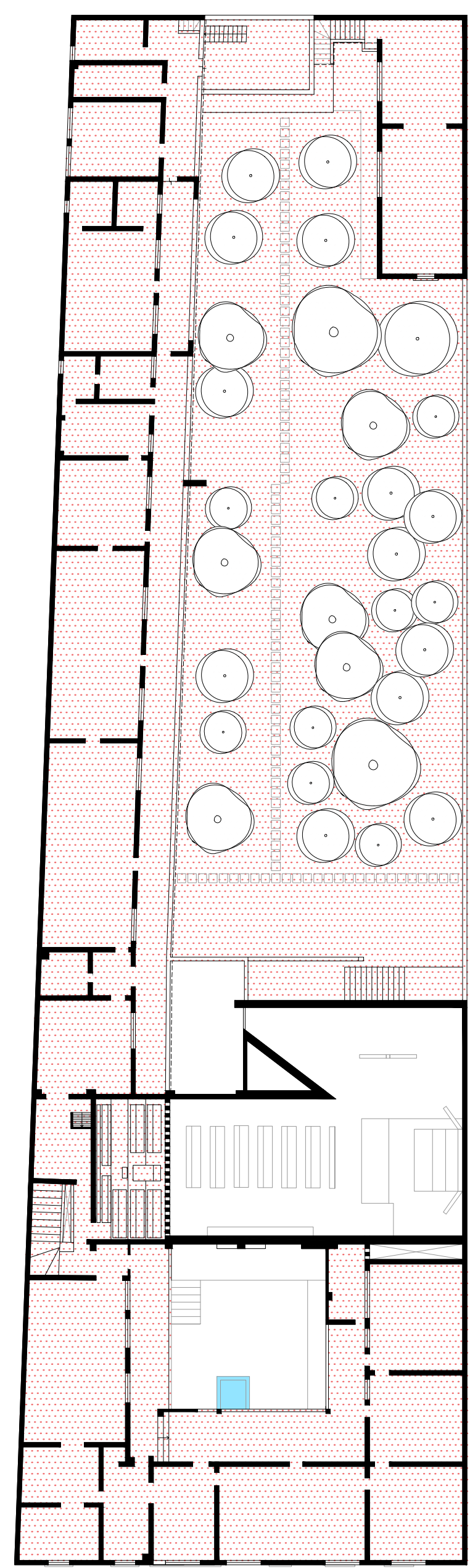

planta pavimento superior

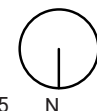





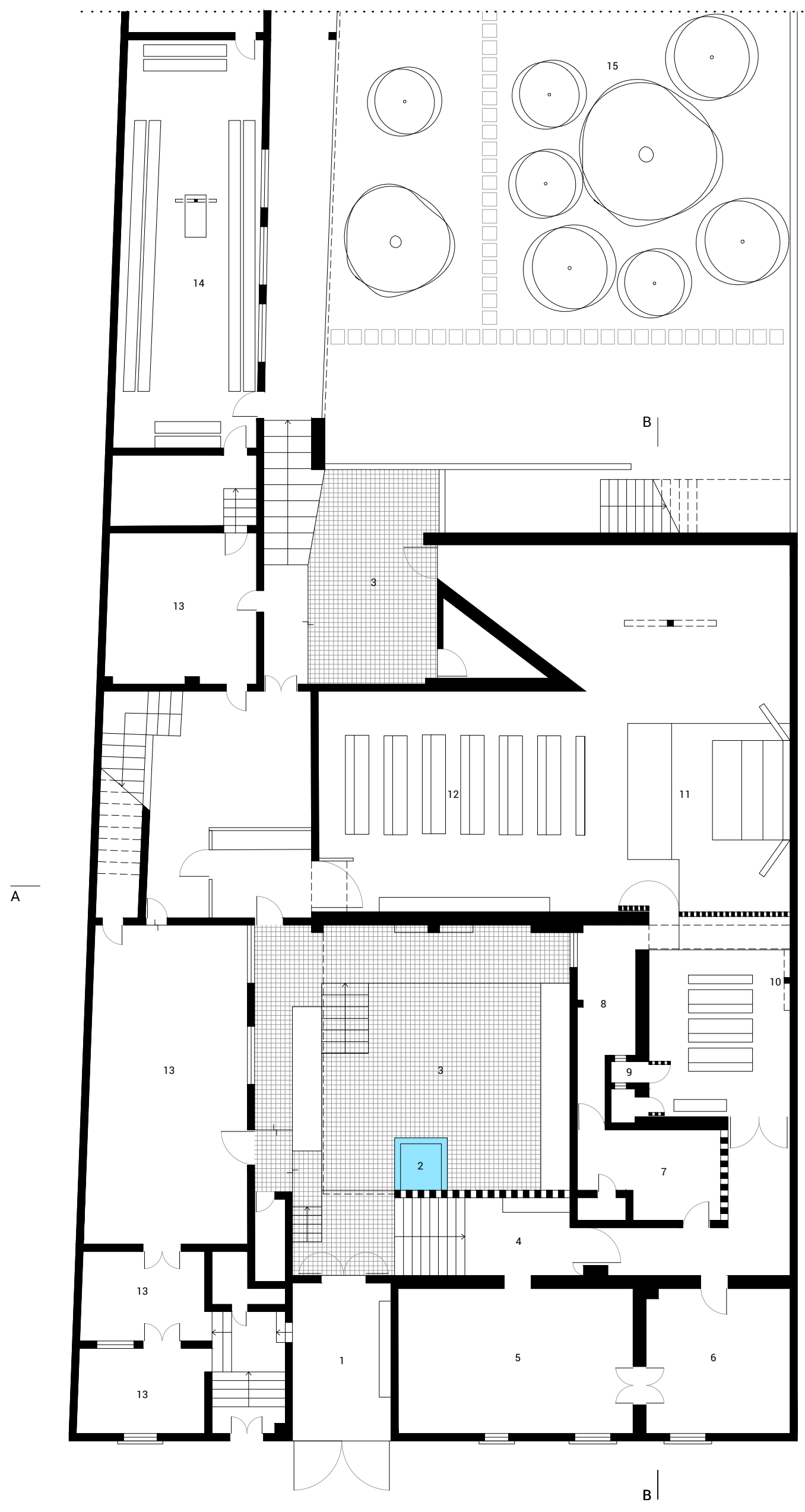

Rua Miguel Hidalgo

planta térreo 



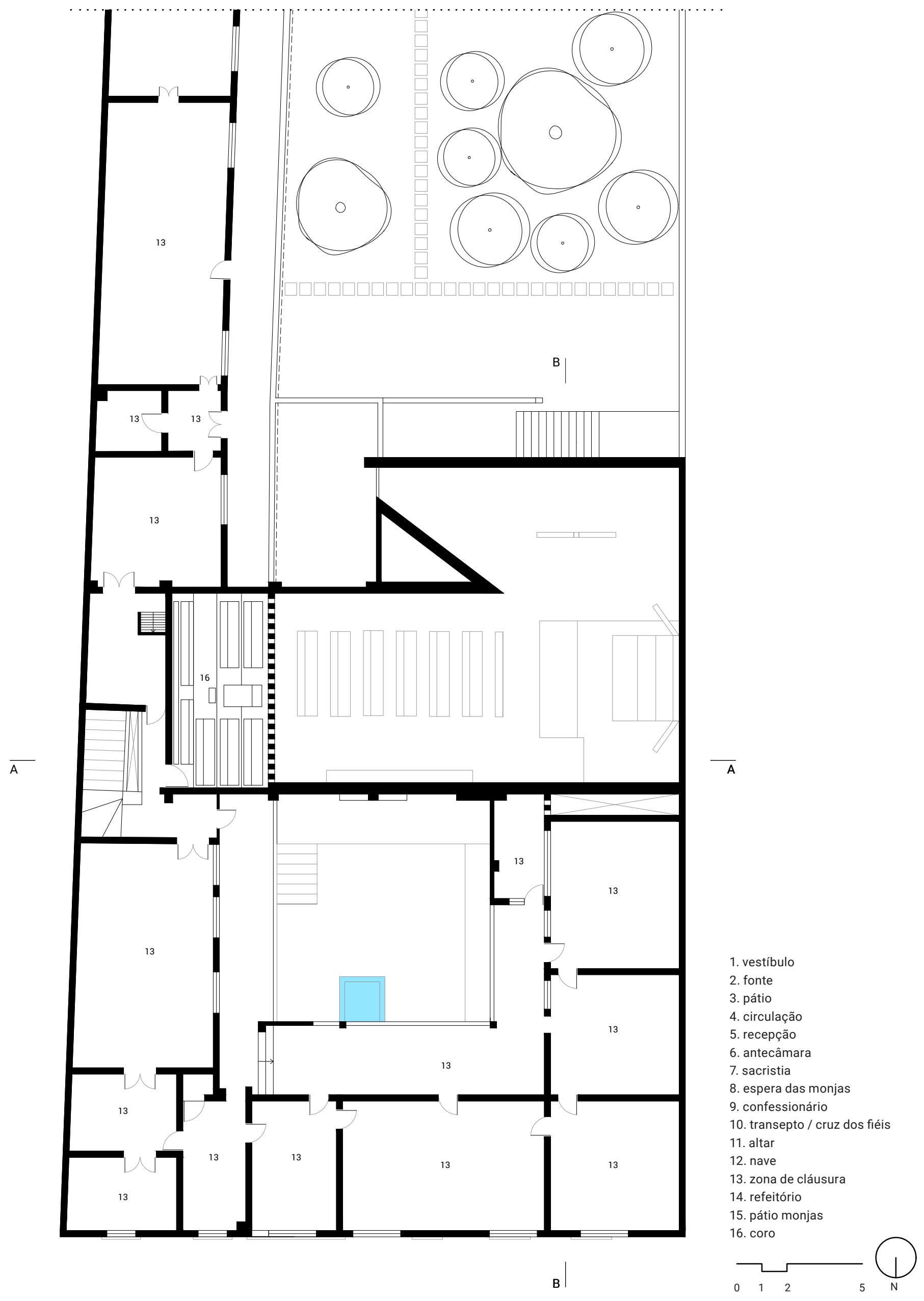

planta pavimento superior 



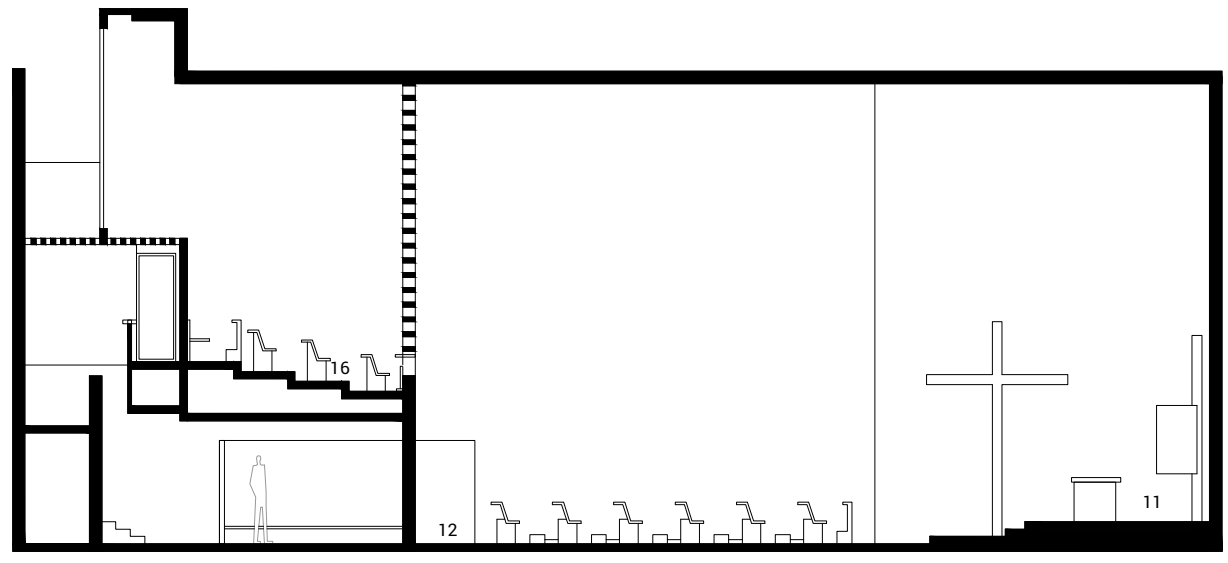

corte A

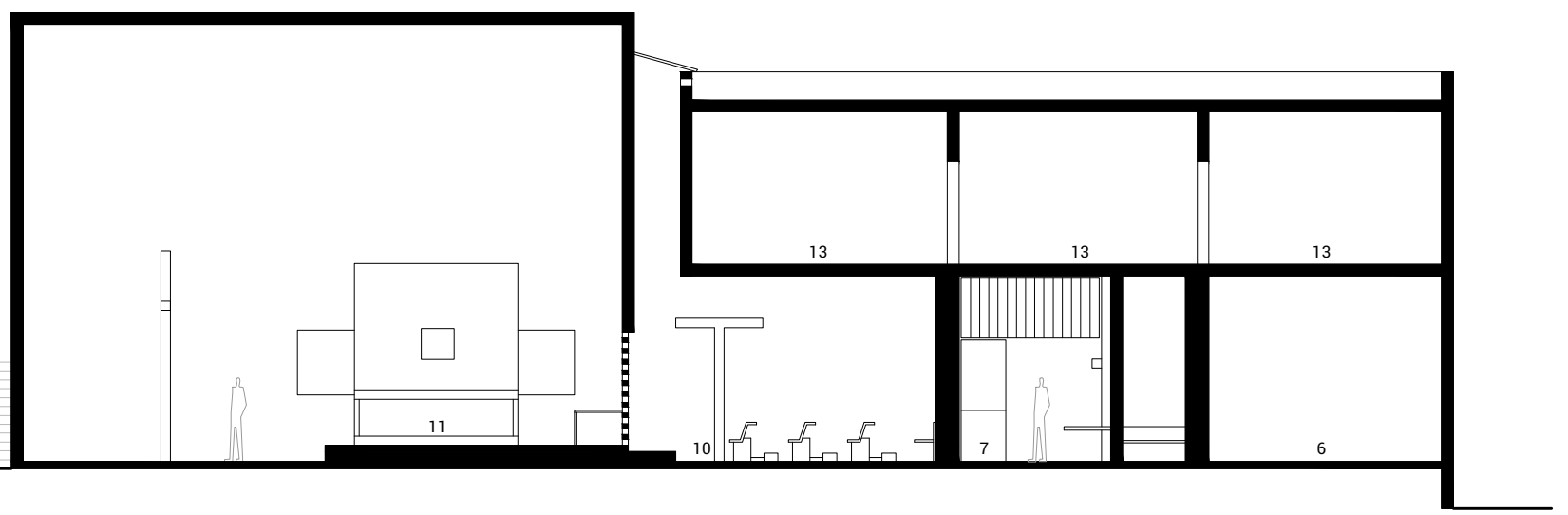

corte B

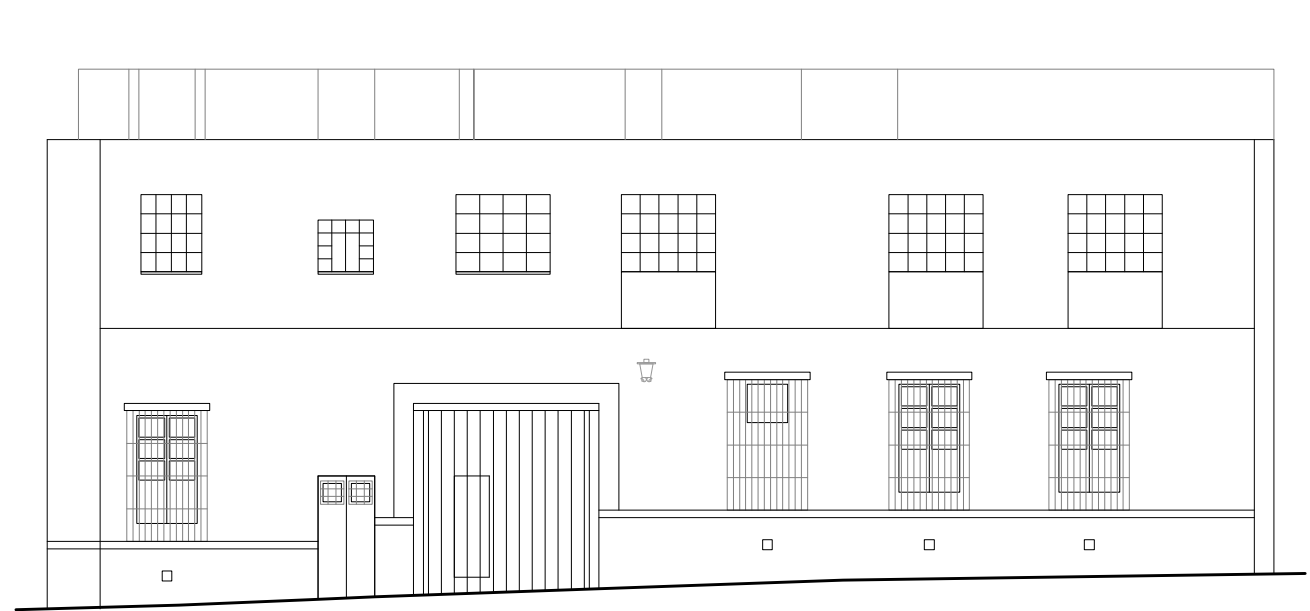

1. vestíbulo

2. fonte

3. pátio

4. circulação

5. recepção

6. antecâmara

7. sacristia

8. espera das monjas

9. confessionário

10. transepto / cruz dos fiéis

11. altar

12. nave

13. zona de cláusura

14. refeitório

15. pátio monjas

16. coro

fachada norte

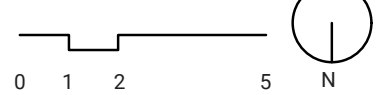






\section{Considerações finais}

Percorrer as três fases da produção arquitetônica de Luis Barragán permitiu reconhecer alguns temas recorrentes na sua trajetória. Atento à sua época, 0 arquiteto, paisagista e urbanista, trabalhou em diferentes escalas ou programas e delineou criteriosamente os espaços através desses elementos imanentes que fizeram parte do vocabulário amplo do arquiteto.

Barragán buscou configurar atmosferas interiores, lugares de serenidade, às vezes, de introspecção, nos quais o jogo de luz e o posicionamento das aberturas, por exemplo, fossem sempre imprescindíveis. Realizou um trabalho persistente com a luz, configurando uma singular luminosidade através das janelas e aberturas que aparecem desde suas obras iniciais em Guadalajara. Usa um dourado constante, obtido através do uso de vidros na cor âmbar, para criar ambientes em tons amarelados. Estratégias que em um primeiro momento podem passar despercebidas, de limites invisíveis que variam de acordo com a estação do ano, se há sol ou chuva e funcionam como filtros sensoriais. Chama atenção aos elementos vernáculos, faz referência às antigas fazendas dos povoados mexicanos com o uso de vigamento de madeira nos tetos, o uso de materiais locais e a configuração de pátios, além de objetos cotidianos da cultura popular - as cerâmicas, os vasos, as esferas de vidro, os adornos religiosos.

Realiza investigação do campo cromático através do uso de cor nas paredes em interlocução com Jesús "Chucho" Reyes e com as cores das festas populares, das feiras, das flores. $\mathrm{O}$ aprimoramento no diálogo do movimento moderno nos traços de Le Corbusier aparece desde a segunda fase com aberturas de piso a teto e escadas, por exemplo. Usufrui da presença da água através das fontes, uma evidente interlocução com Ferdinand Bac. Por fim, constitui forte relação com a topografia e o desenho dos jardins que o devolve à memória de infância a experiência da paisagem original, vínculo com a natureza.

Em 1945, Le Corbusier escreveu sobre o Espaço Indizível, dizendo que a chave da emoção estética é uma função espacial (ROZESTRATEN, 2015, p. 238-241). A reflexão sobre vida e obra de Luis Barragán permite reconhecer a busca de uma emoção, da dualidade entre o espiritual e o material. Mesmo quando, na escala da 
cidade, em obras da terceira fase, anônimas, a beleza ocorre escondida atrás de grandes muros.

A construção do imaginário do arquiteto evidencia a síntese alcançada em sua obra. Talvez, um ato sublime da imaginação poética evoque diretamente à experiência da emoção estética para quem visita suas obras. Uma emoção compatível à admiração nos termos de Valéry:

O que fica de um homem é o que nos levam a pensar seu nome e as obras que fazem desse nome um signo de admiração, de ódio ou de indiferença. Pensamos que ele pensou, e podemos reencontrar entre suas obras esse pensamento que lhe é dado por nós: podemos refazer esse pensamento à imagem do nosso. (VALÉRY, 1919, p. 9)

O fechamento da pesquisa permitiu um jogo de imagens sobrepostas e justapostas, com seus respectivos filtros, revelando elementos recorrentes na produção ampla de Luis Barragán. 


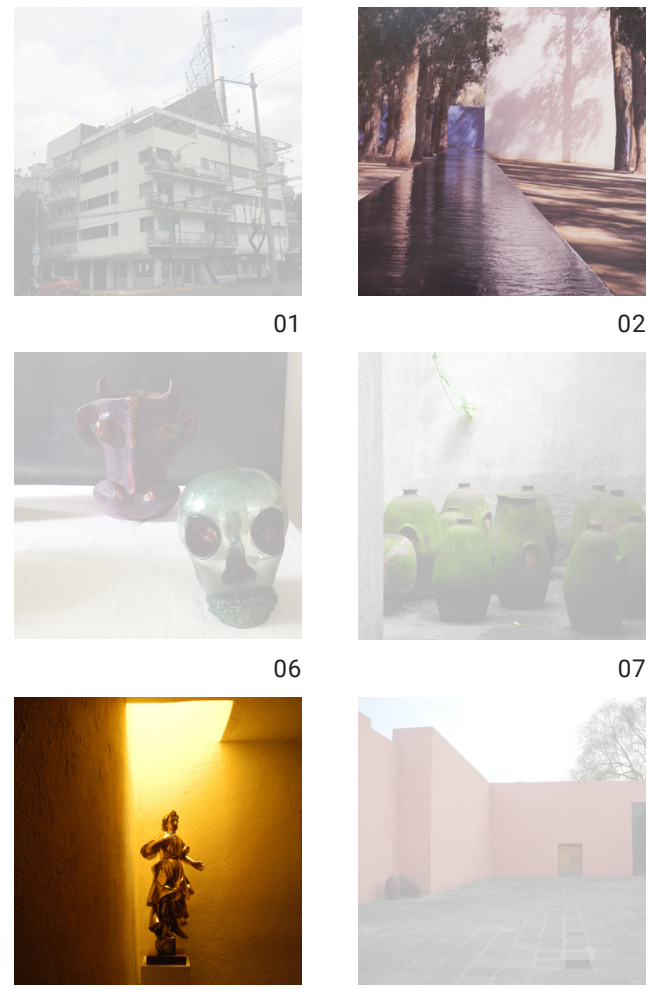

11
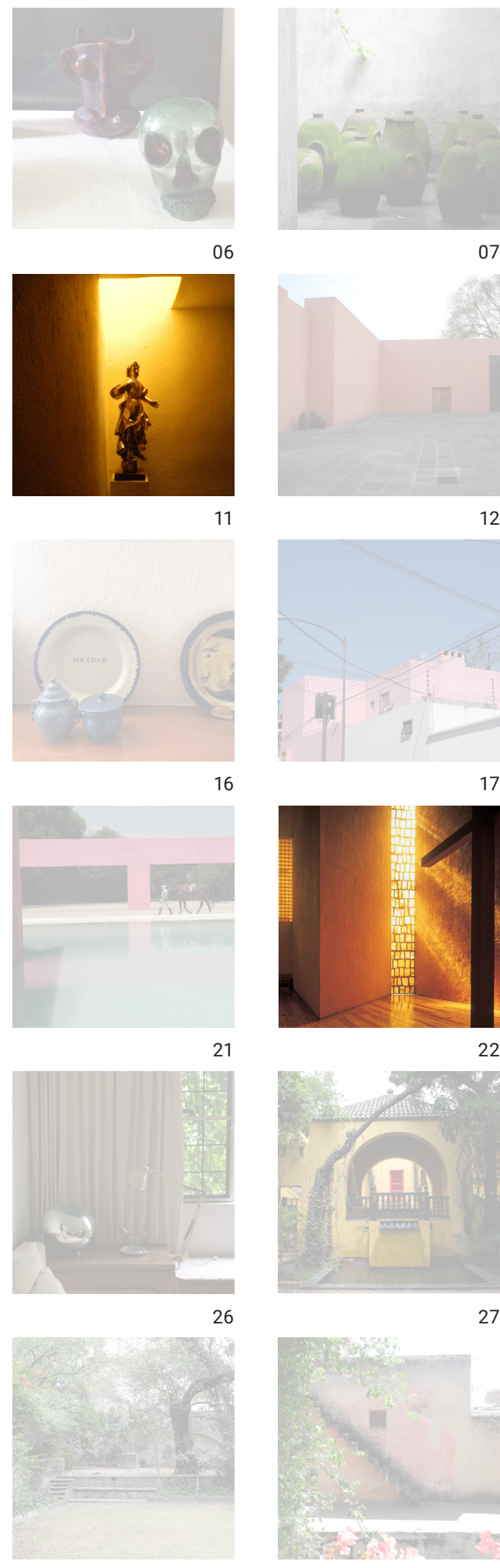

12

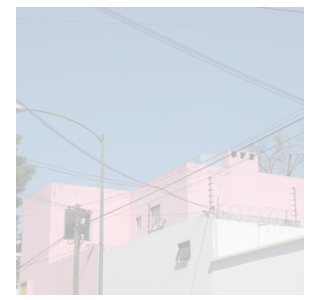

17
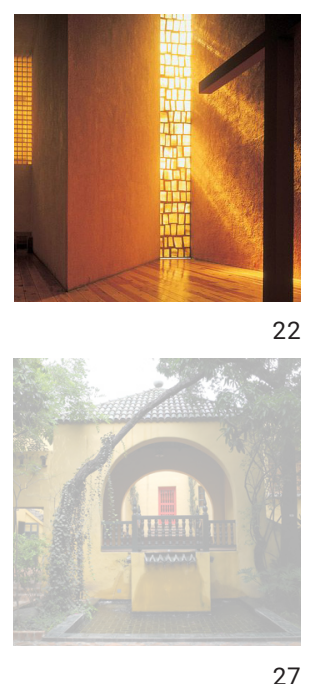

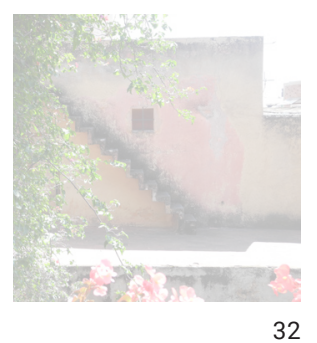

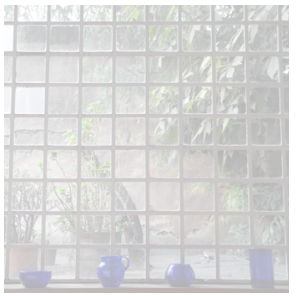

03
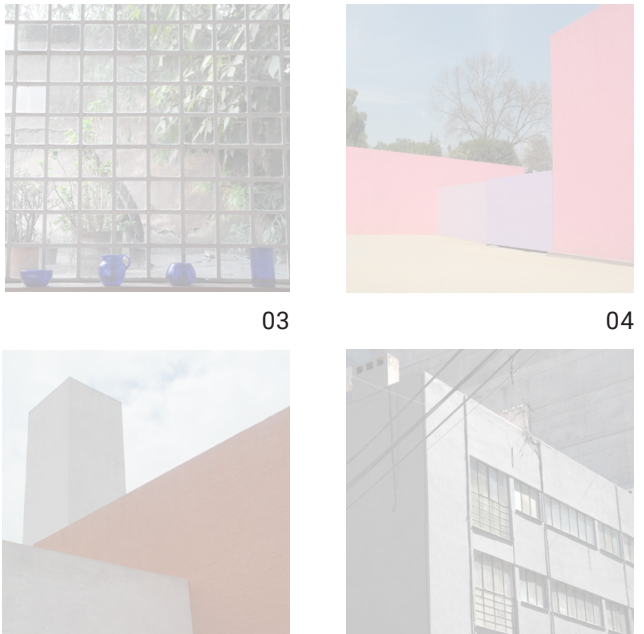

04

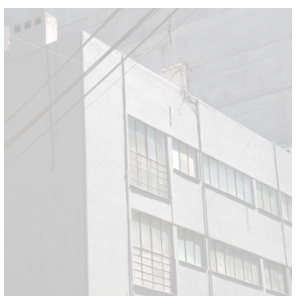

09
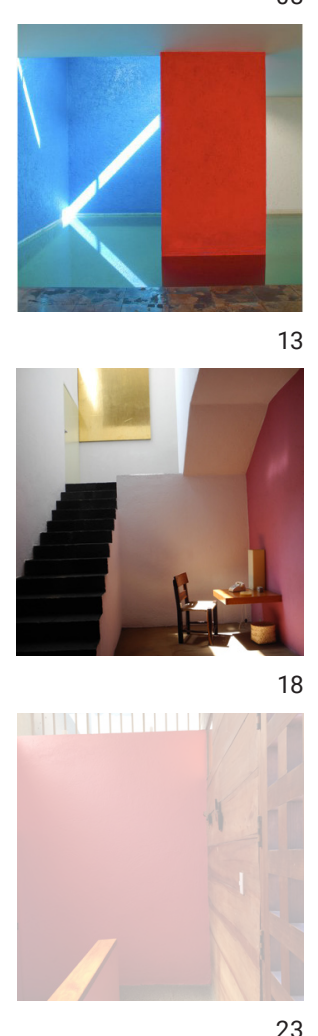

23

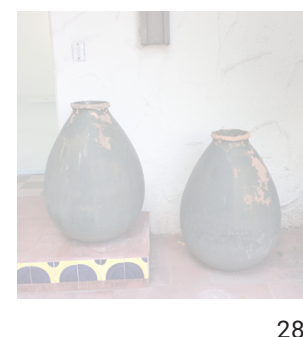

28

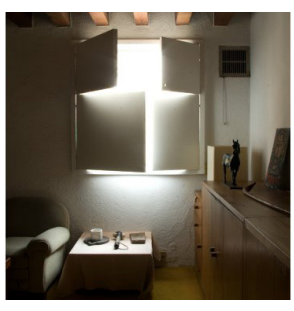

33
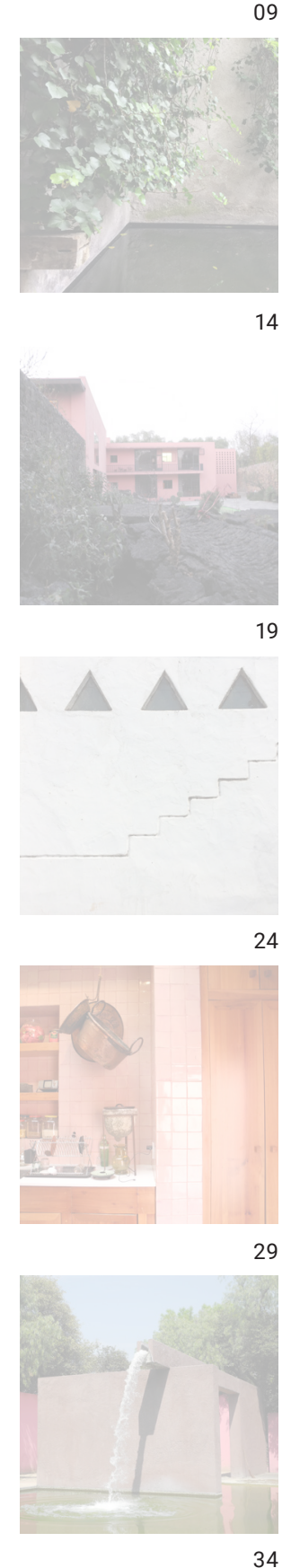

24

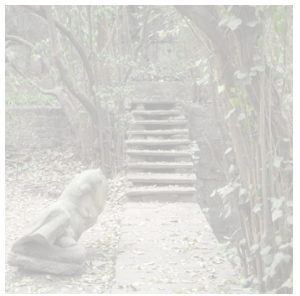

05

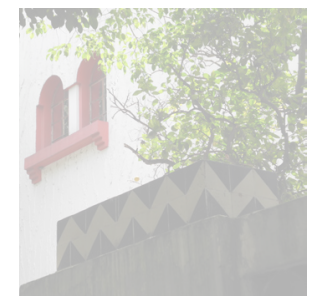

10
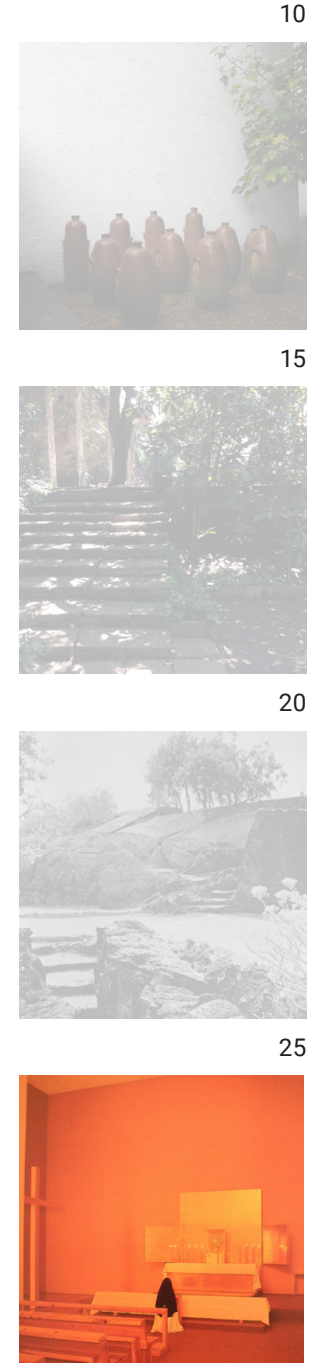

30

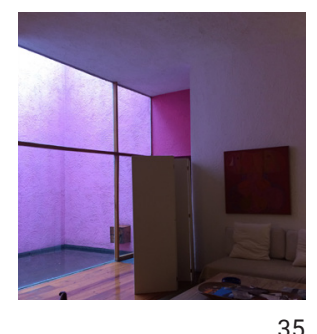

DESENHO DA LUZ 


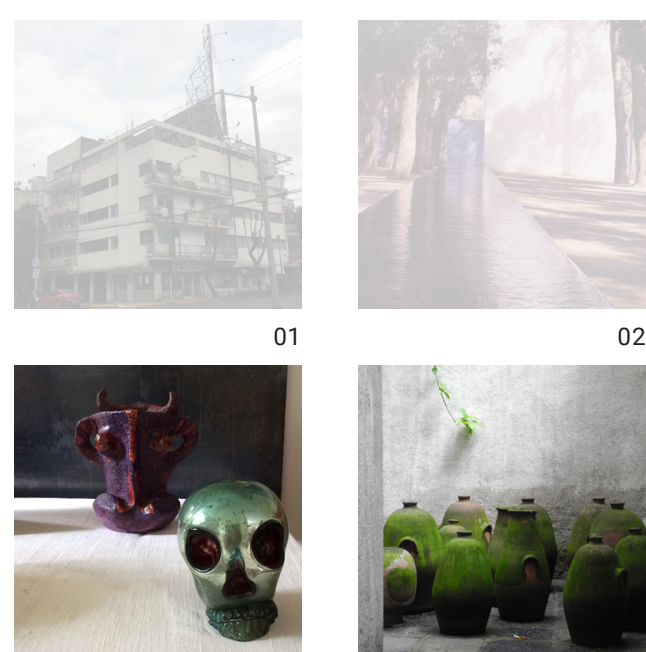

06

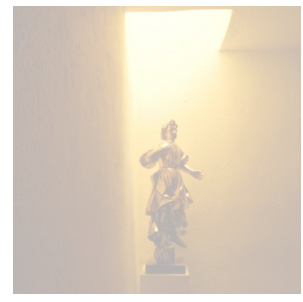

11

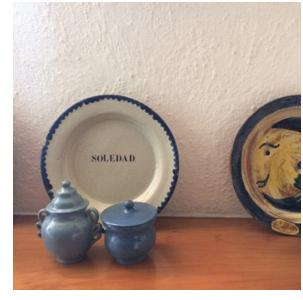

16

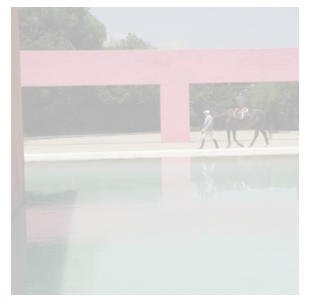

21

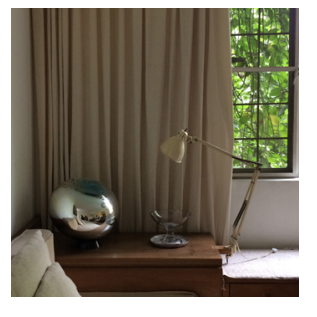

26

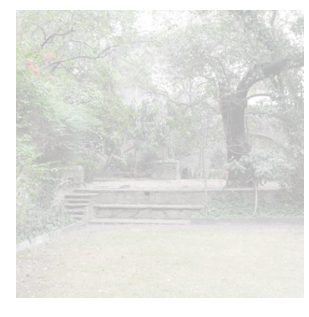

02

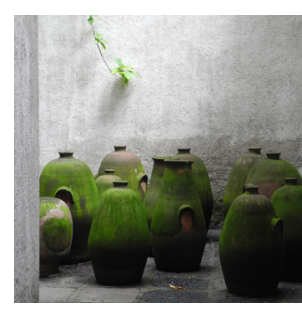

07

12

17

22
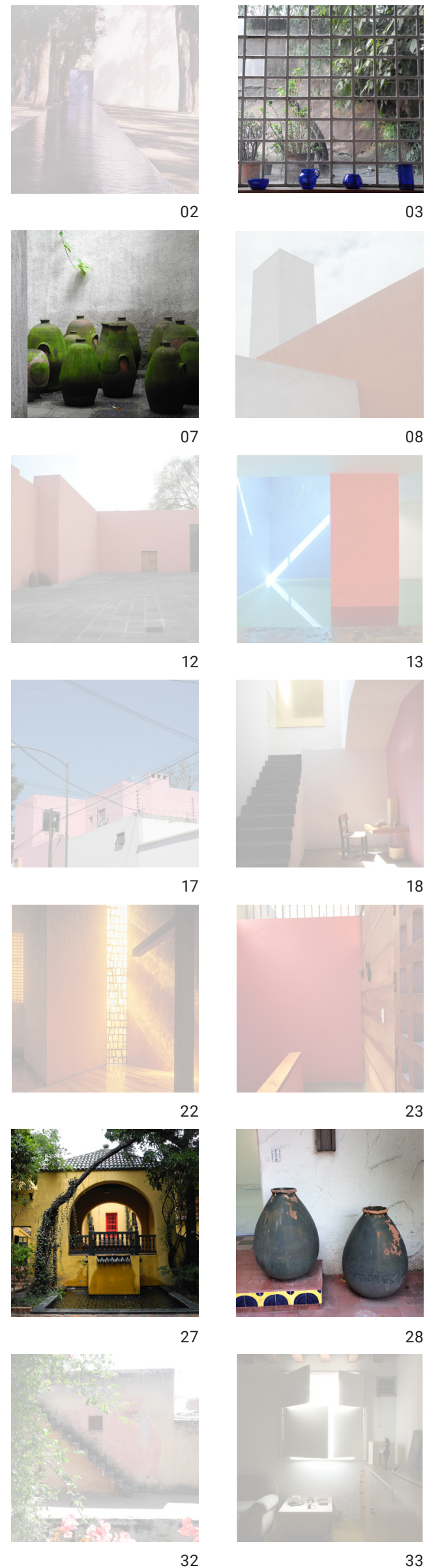

08

13

18

23

28

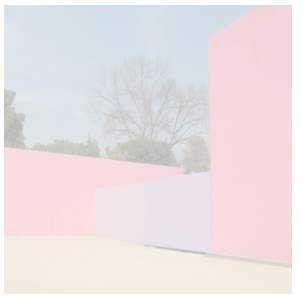

04
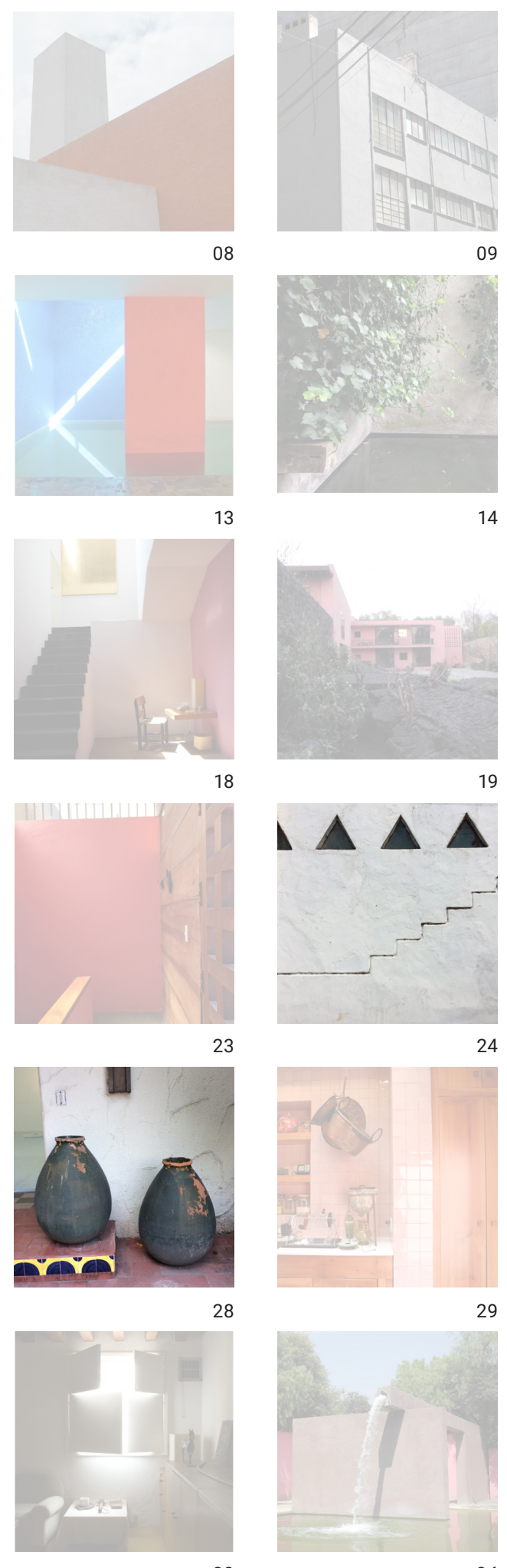

09
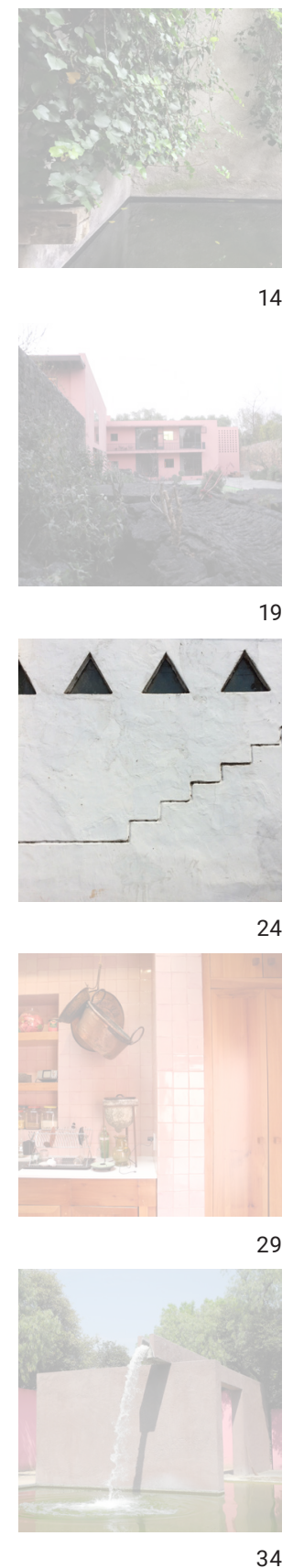
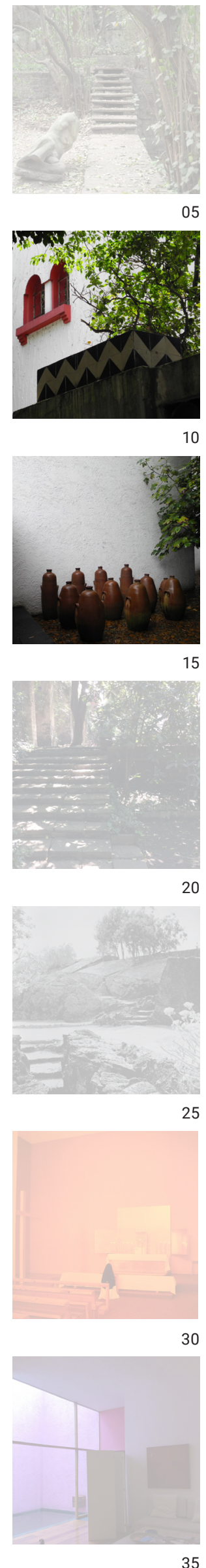

USO DE ELEMENTOS VERNÁCULOS 



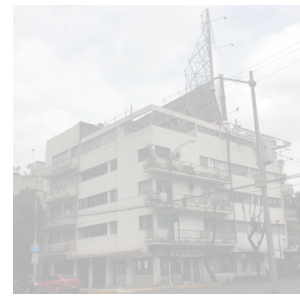

01

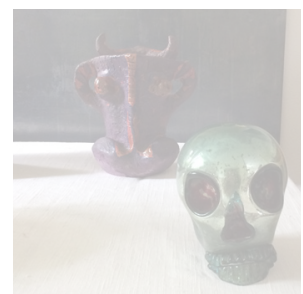

06

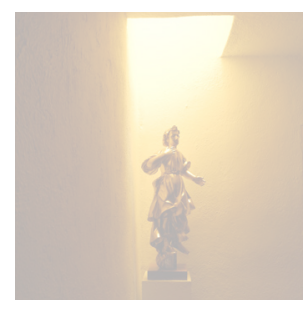

11

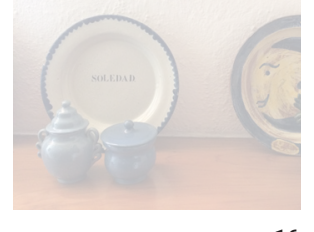

16
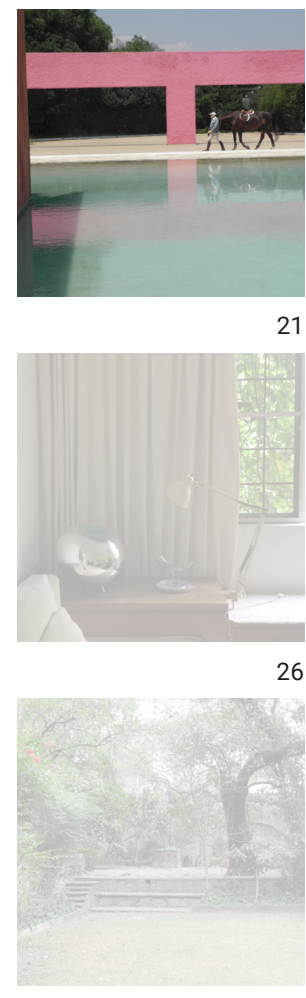
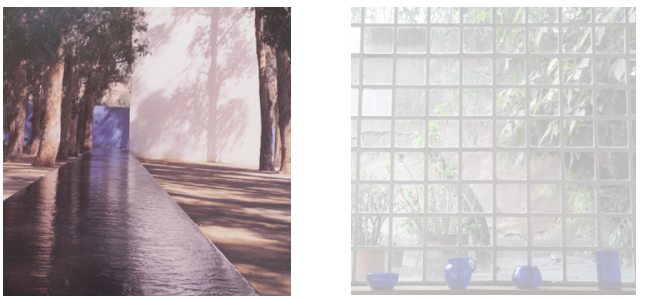

03

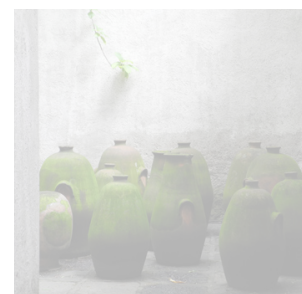

07

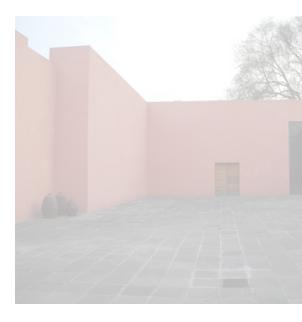

12

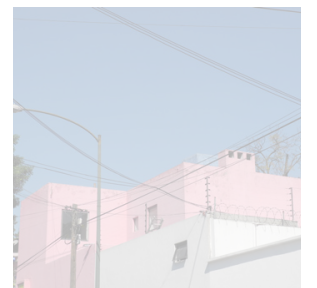

17
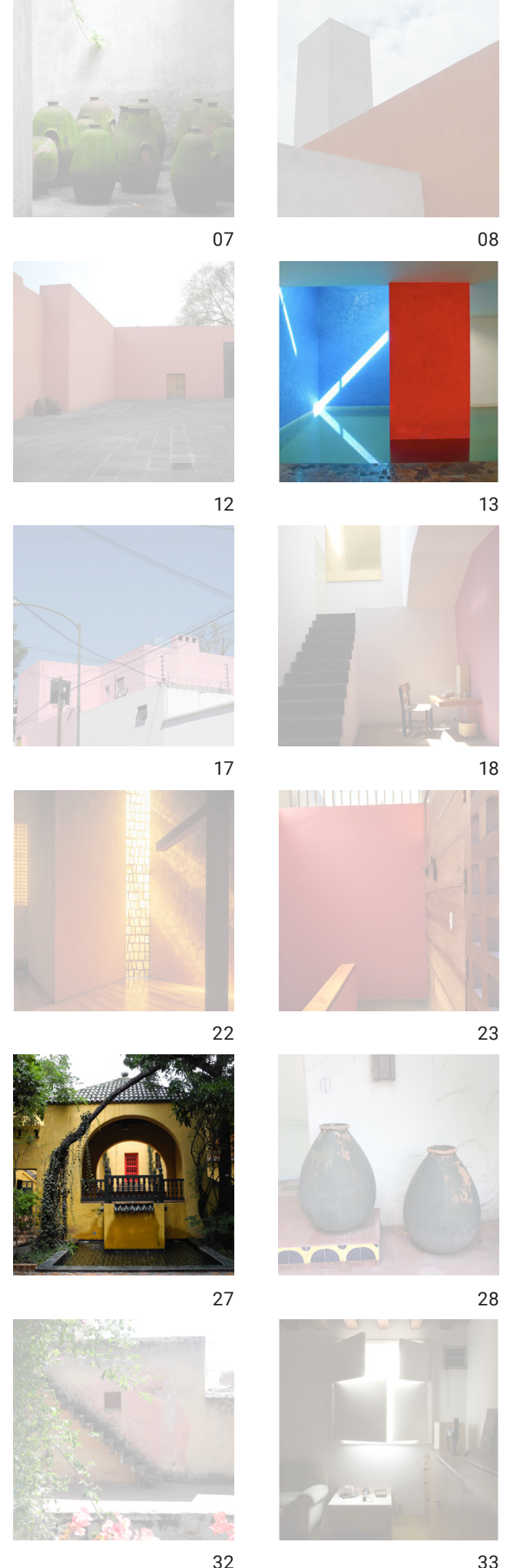

18

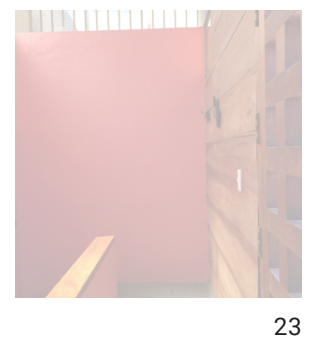

23

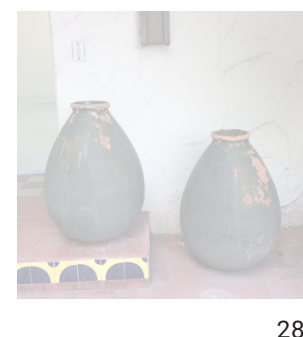

28

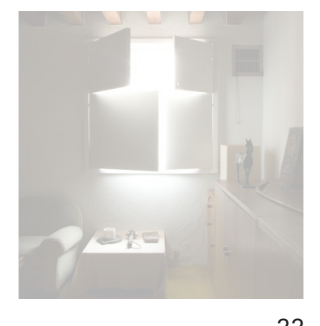

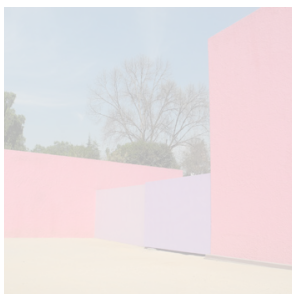

04

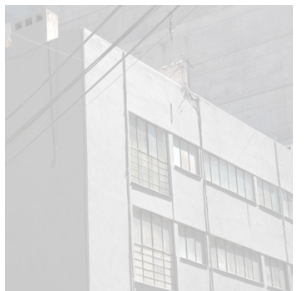

09
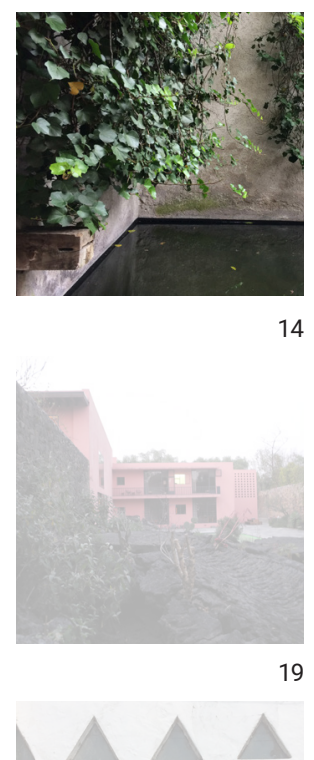

24

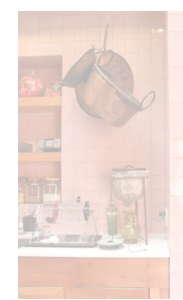

29

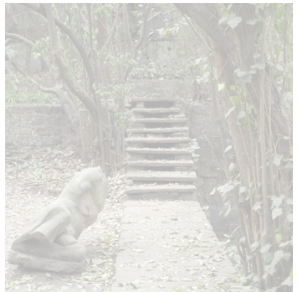

05

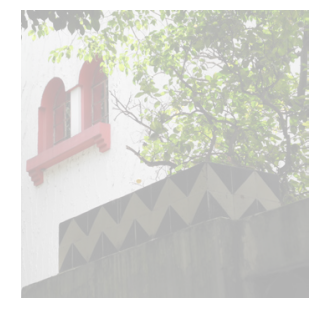

10
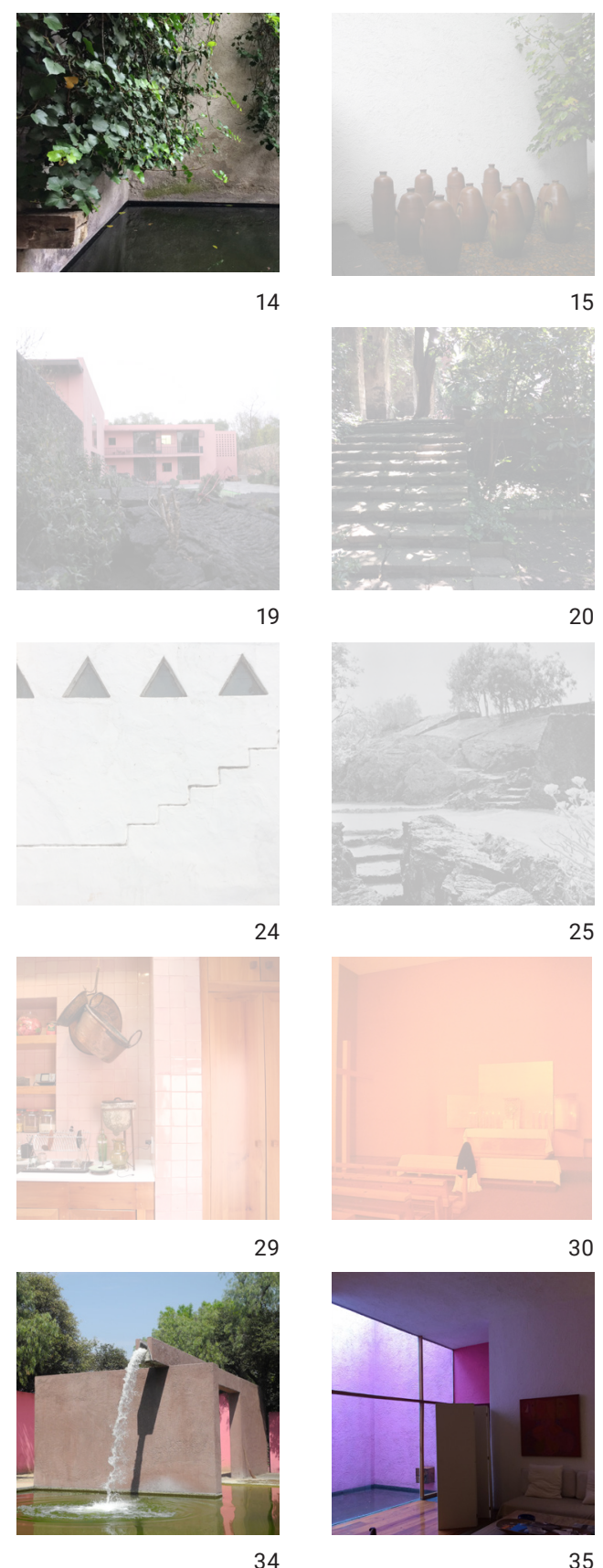

30

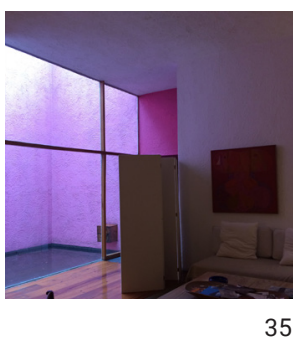

PRESENÇA DA ÁGUA 



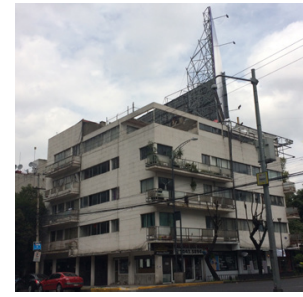

01

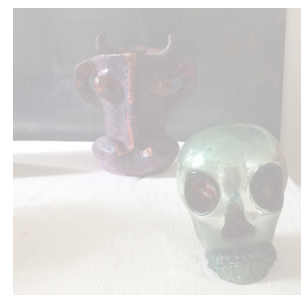

06

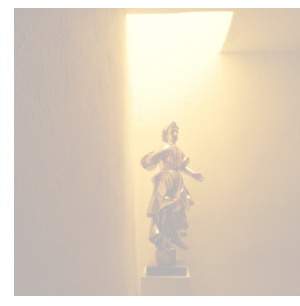

11
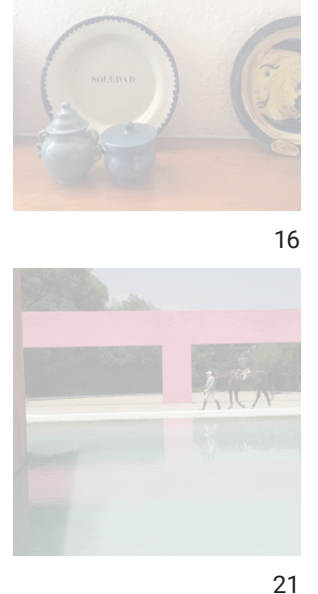

21
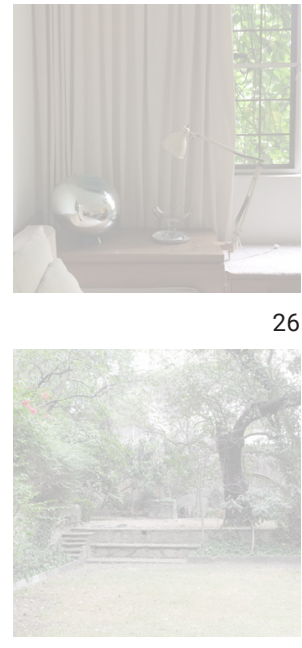

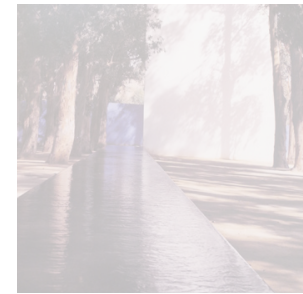

02

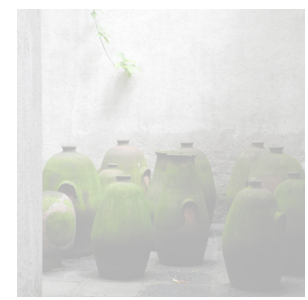

07

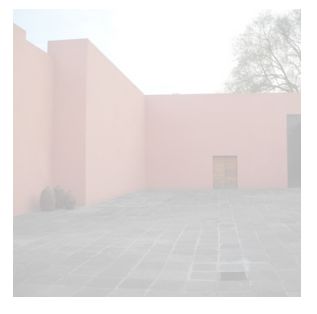

12

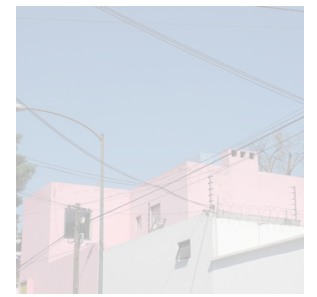

17
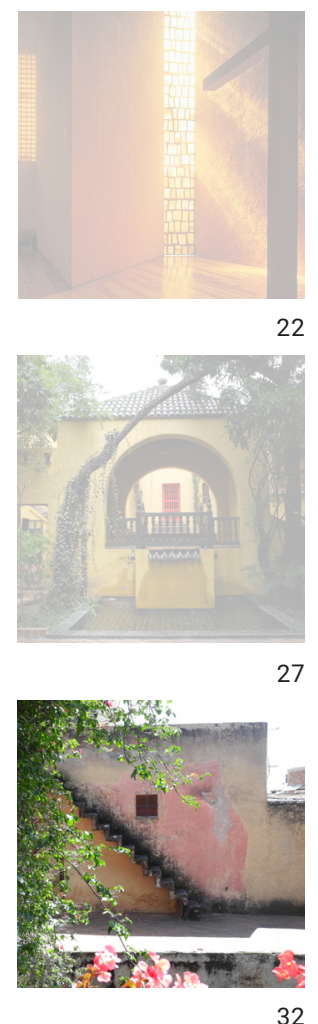
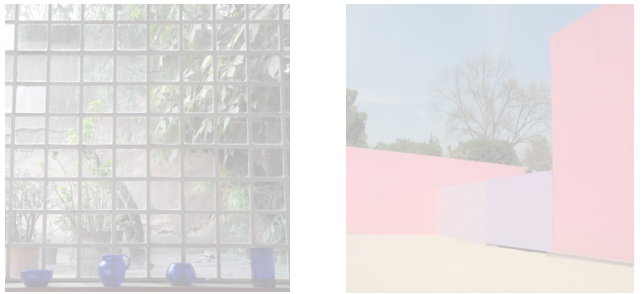

04

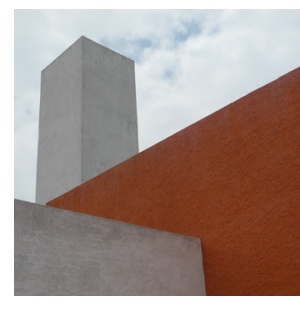

08

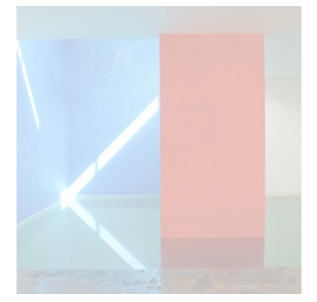

13

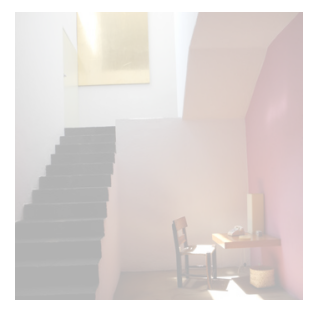

18

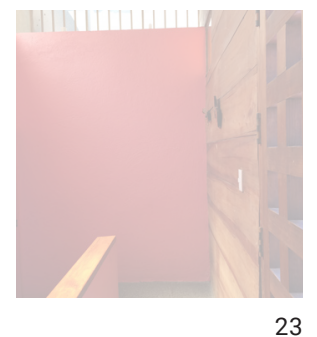

23

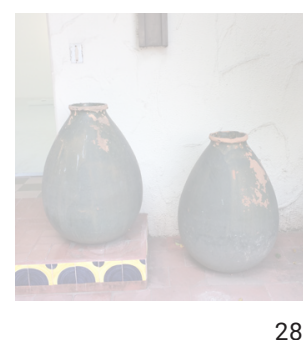

28

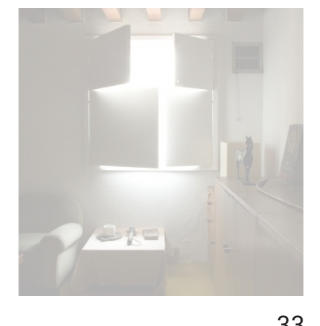

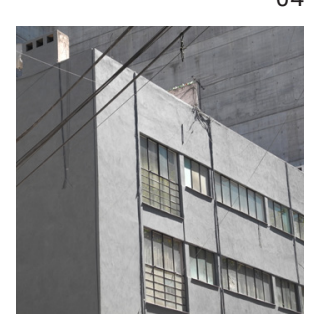

09

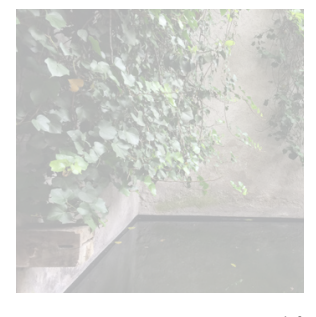

14
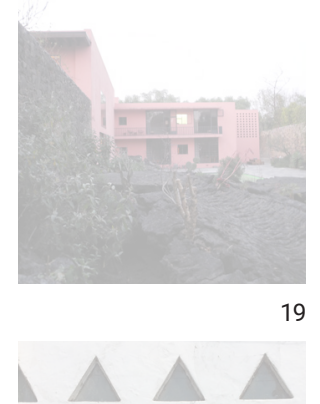

24
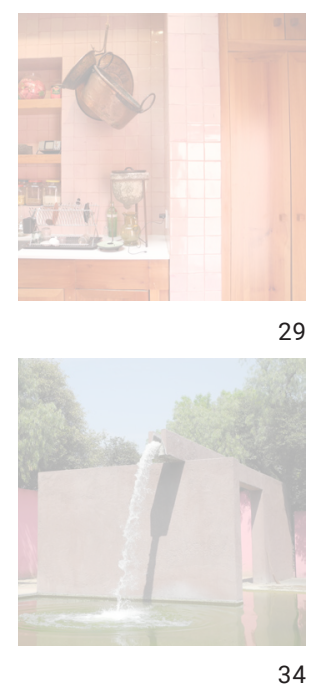

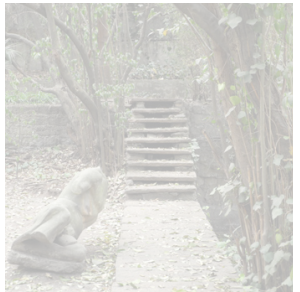

05

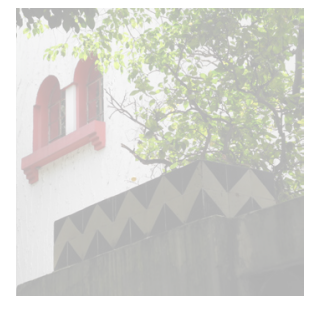

10
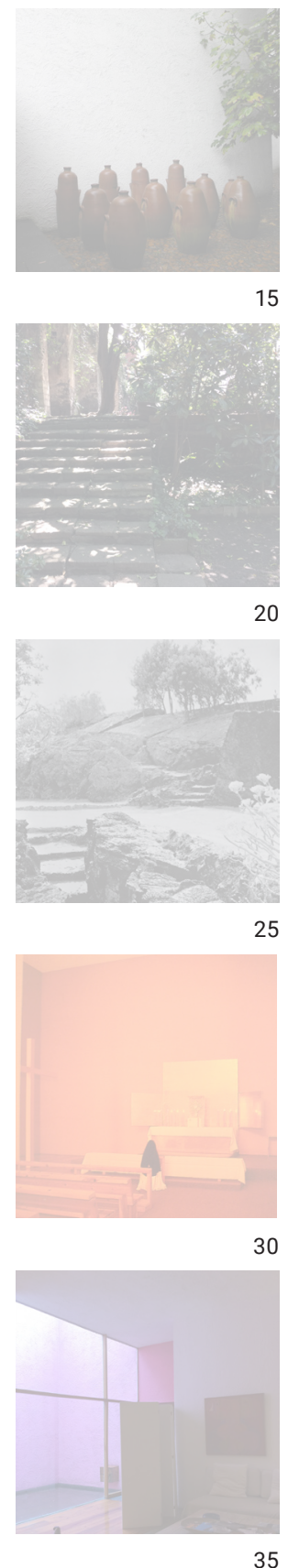

TRAÇOS DE LE CORBUSIER 


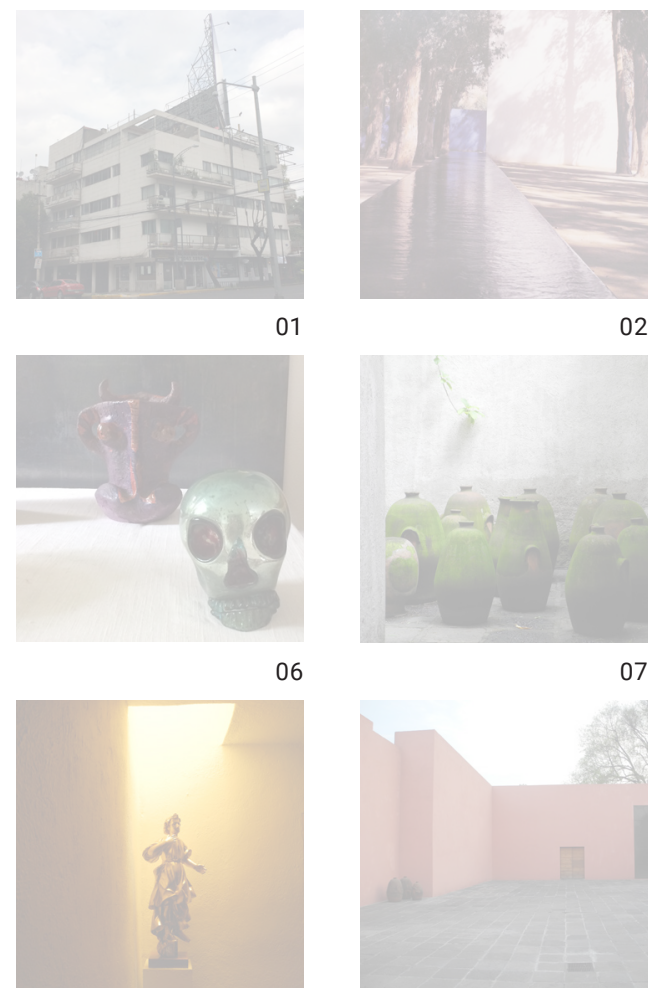

11
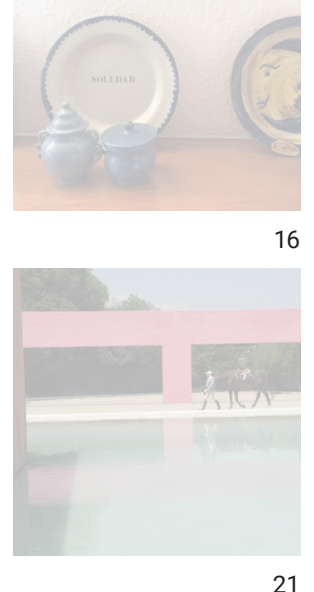

21

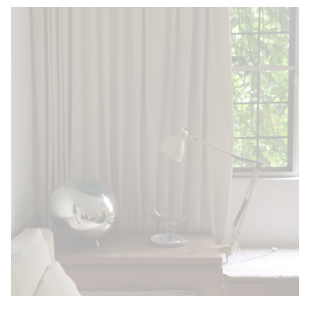

26

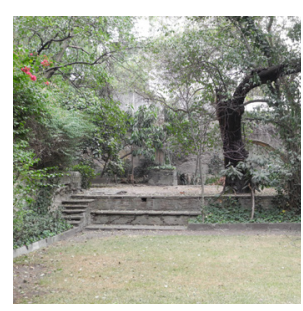

31

02

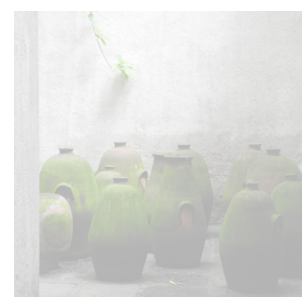

07

12

17

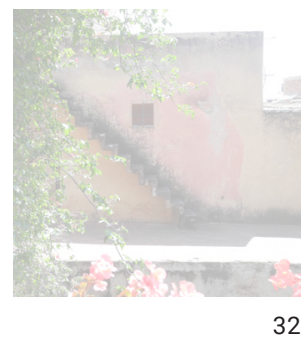

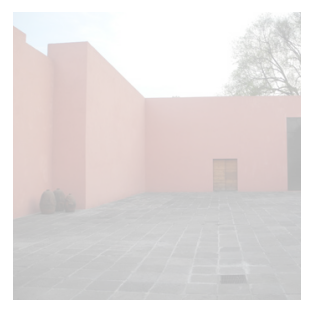
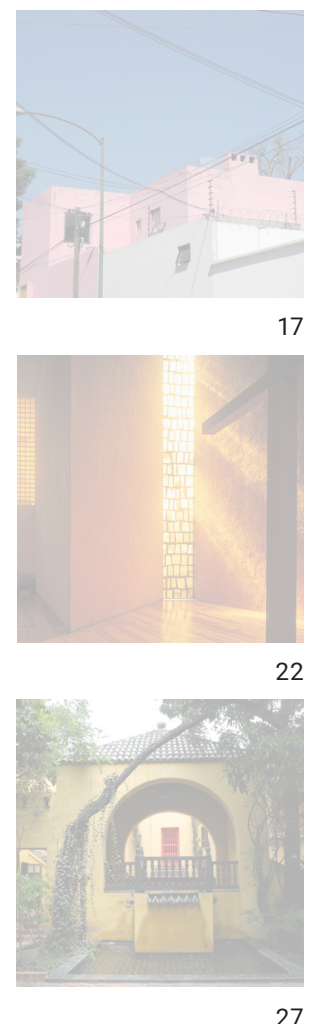
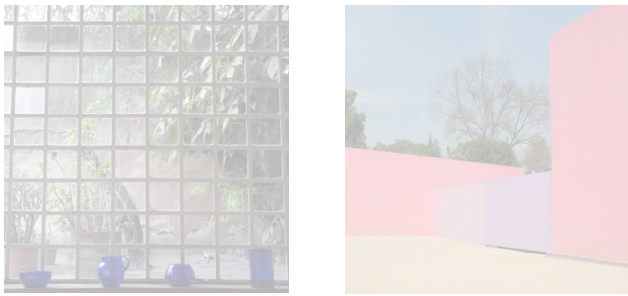

04

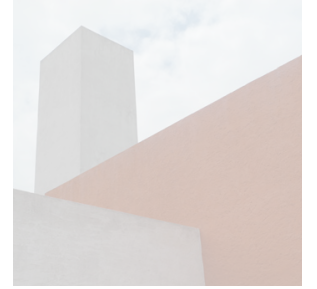

08

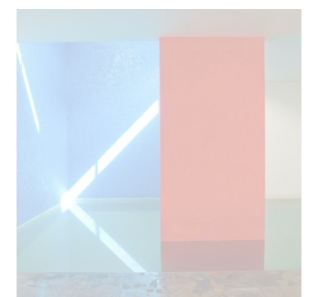

13

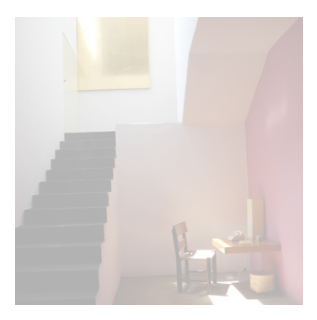

18

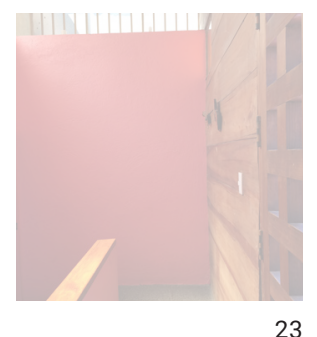

23

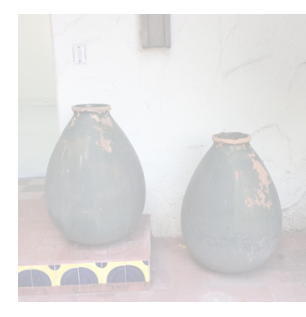

28

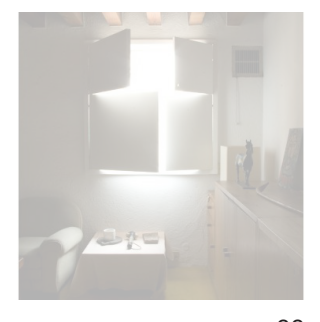

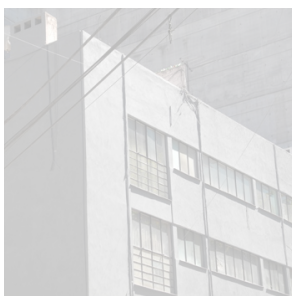

09
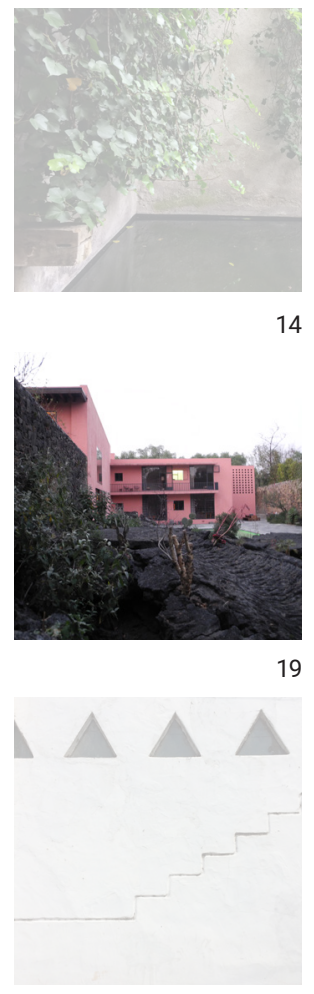

24
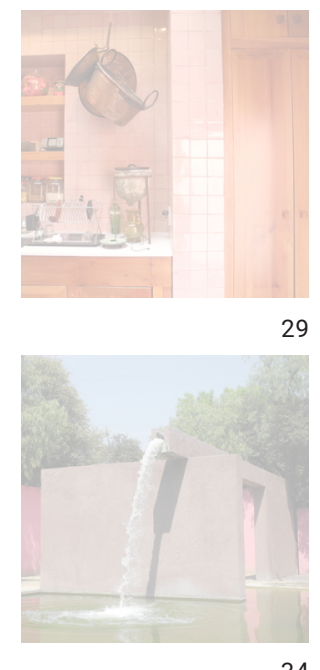

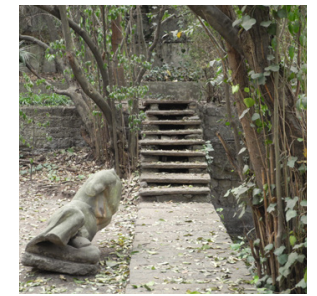

05

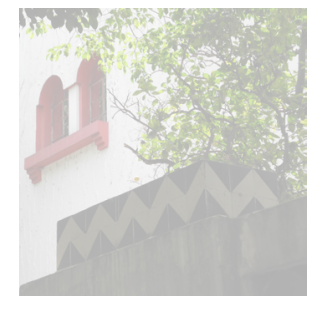

10
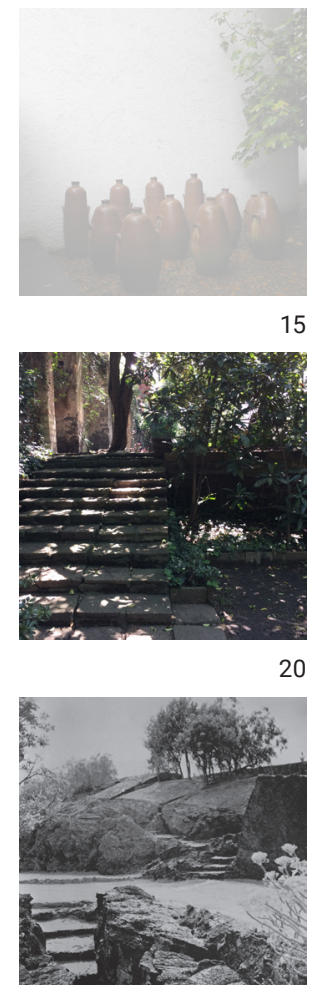

25

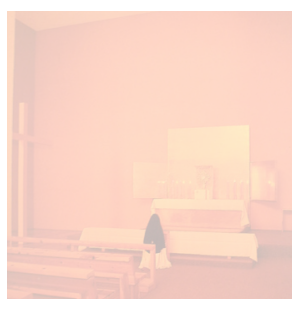

30

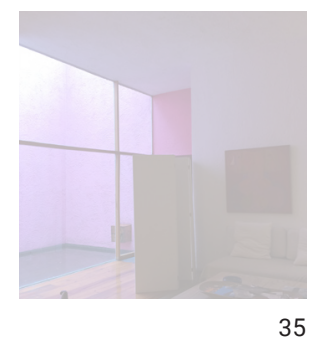

RELAÇÃO COM A TOPOGRAFIA 


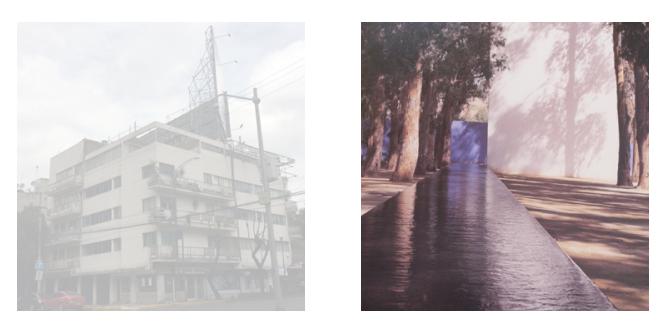

01
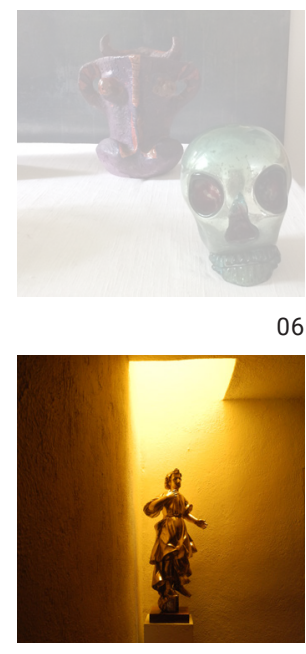

11
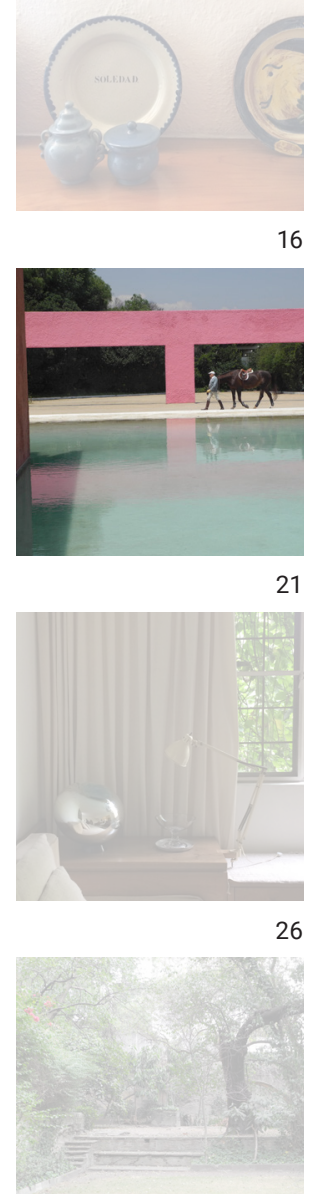

31
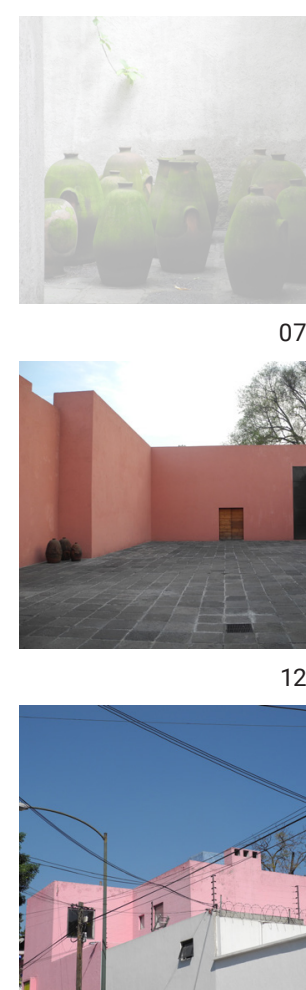

12
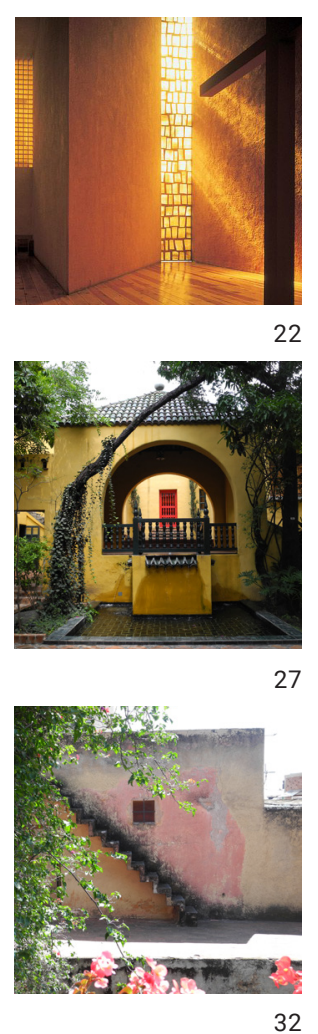
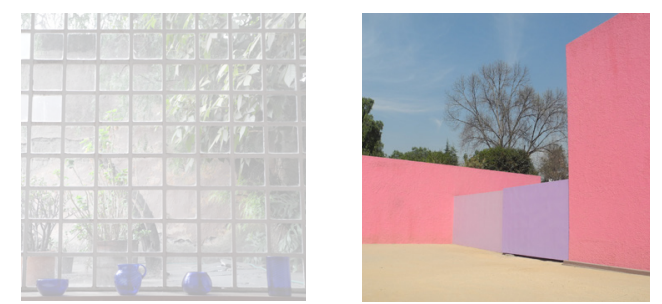

03
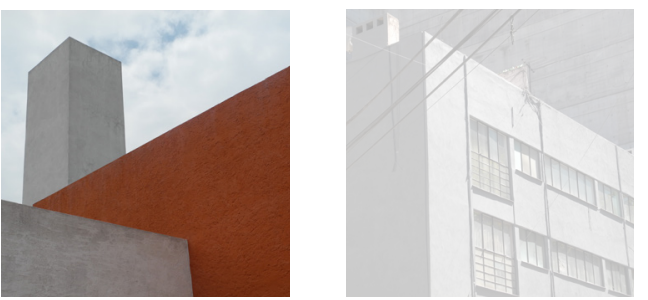

09

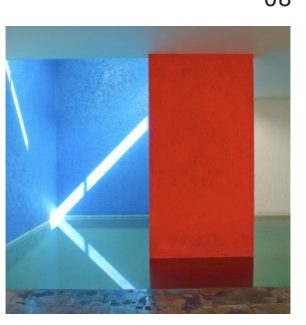

13
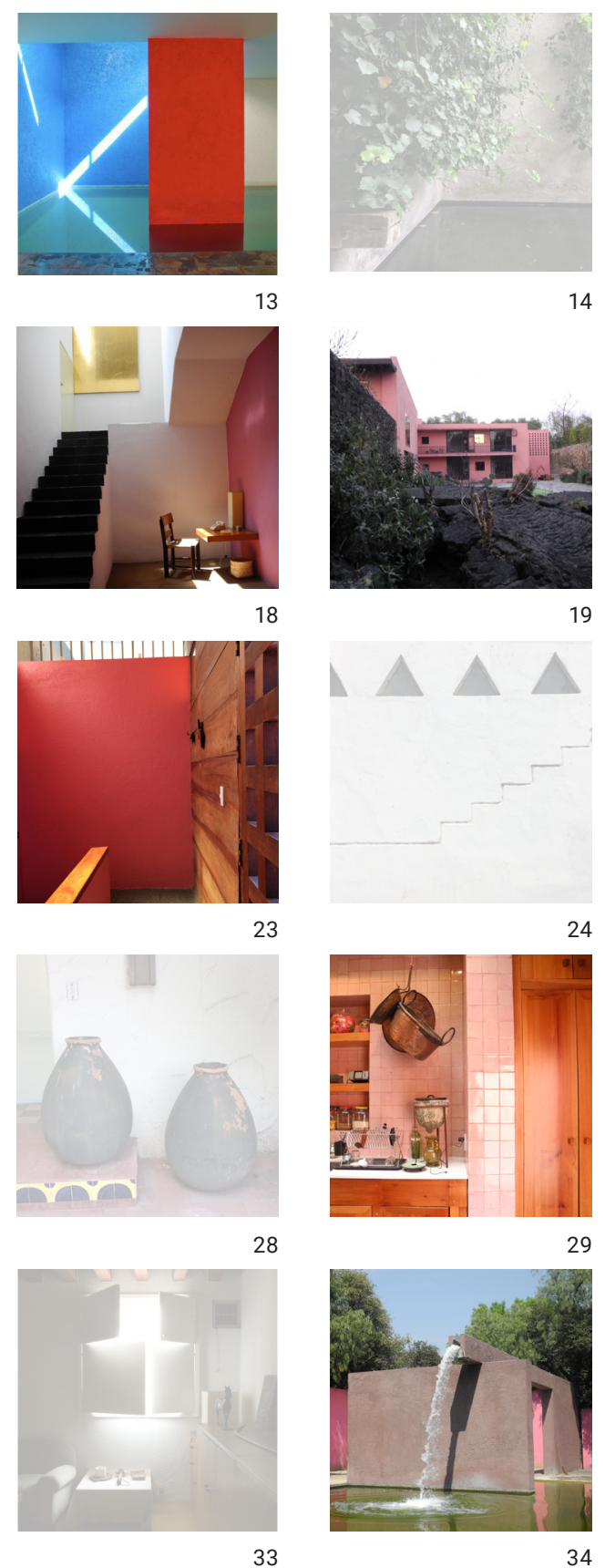
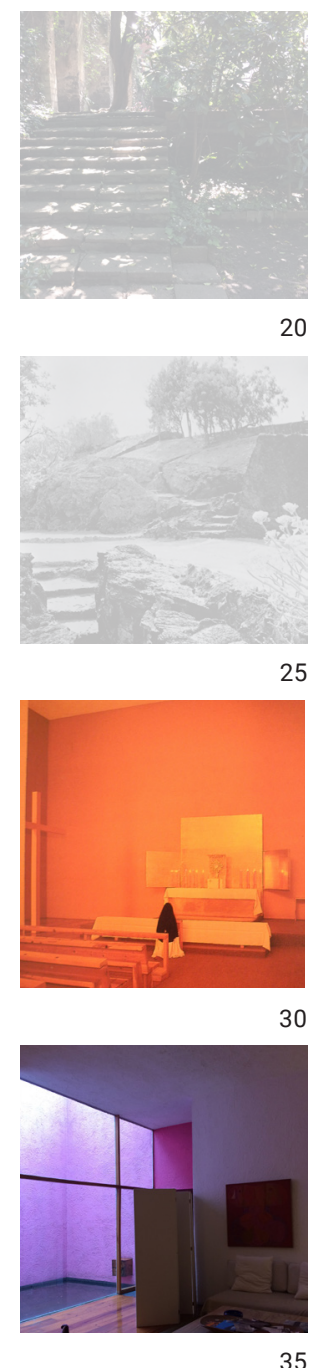

CAMPO CROMÁTICO 


\section{Lista de imagens}

\section{Prólogo}

01 a 08 Capela e Ampliação Convento de Tlalpan, Luis Barragán, 1953-1960 e 1979-1980. Fotografias de Armando Salas Portugal, sem data. Disponível em: SALAS, Armando Portugal. Fotografías de la arquitectura de Luis Barragán. Barcelona: Gustavo Gili, 1992.

\section{Introdução}

01 Luis Barragán. Fotografia de Fulvio Roiter. Disponível em: ZANCO, Federica e VALENTE, Ilaria. Guía Barragán. Cidade do México: Fundação Barragán / Arquine, 2011.

\section{Primeira fase (1927-1935)}

01 a 06 Fotografias de Juan Rulfo. Disponíveis em: RULFO, Juan. Letras e imágenes. México: Editorial RM, 2002.

07 Povoado mexicano, sem data. Fotografia arquivo Barragán. Disponível em: RIGGEN, Antonio Martinez. Luis Barragán: escritos y conversaciones. Madri: Ed. El Croquis, 2000.

08 a 10 Fotografias povoados mexicanos. Fotografias da autora, 2017. Arquivo pessoal.

11 Croquis localização Sierra del Tigre. Elaboração da autora. Arquivo pessoal. 12 Mapa localização rancho da família de Barragán. Elaboração da autora. Arquivo pessoal.

13 a 20 El Volantín, Jalisco e ruínas da família Barragán. Fotografias da autora, 2017. 21 Alhambra, Granada, Espanha. Disponível em: ANTEQUERA, Marino. La Alhambra y el Generalife. Granada: Editorial "Padre Suarez", 1961.

22 Luis Barragán em Alhambra. Disponível em: PAULY, Danièle. Barragán. L'espace et L'ombre, le mur et la couleur. Basel - Boston - Berlim: Birkhauser, 2002.

23 a 25 Alhambra. Disponível em: ANTEQUERA, Marino. La Alhambra y el Generalife. Granada: Editorial "Padre Suarez", 1961.

26 a 30 Postais de viagem Luis Barragán, sem data. Arquivo Fundação Barragán Cidade do México.

31 a 31 Casas no centro de Gualajara (setor Hidalgo), Luis Barragán, 1928-1929.

Fotografias da autora, 2017. Arquivo pessoal. 
36 a 40 Casa Cristo, Luis Barragán, Gualajara, 1929. Fotografias da autora, 2017. Arquivo pessoal.

41 a 45 Casas Franco, Luis Barragán, Gualajara, 1929. Fotografias da autora, 2017. Arquivo pessoal.

47 e 48 Casas Robles Castillo, Luis Barragán, Gualajara, 1927-1928. Fotografias da autora, 2017. Arquivo pessoal.

49 Casa González Luna, Luis Barragán, Gualajara, 1928-1929. Fotografias da autora, 2017. Arquivo pessoal.

50 Casa Harper de Garibi, Luis Barragán, Gualajara , 1934. Fotografias da autora, 2017. Arquivo pessoal.

51 a 55 Povoados mexicanos, Jalisco. Fotografias da autora, 2017. Arquivo pessoal. 56 Implantação Casa González Luna. Ilustração elaborada pela autora. Arquivo pessoal.

57 a 60 llustrações de Ferdinand Bac. Disponíveis em: BAC, Ferdinand. Jardins Enchantés. Paris: Louis Conard, 1925.

61 a 82 Casa González Luna, Luis Barragán, 1928-1929. Fotografias da autora, 2017. Arquivo pessoal.

\section{Segunda fase (1936-1944)}

01 Carta Le Corbusier. Disponível em: NOELLE, Louise. Luis Barragán. Búsqueda y creatividad. México: UNAM, 2004 (1ª edição 1996).

02 Casa do pintor Ozenfant em Paris, Le Corbusier, 1922. Disponível em: BOESIGER, Willy. Le Corbusier. São Paulo: Martins Fontes, 1994.

03 a 05 Casa Estúdio José Clemente Orozco em Guadalajara, Luis Barragán, 1934.

Fotografias da autora. Arquivo pessoal.

06 e 07 Pinturas Le Corbusier, 1919. Nature morte à lóuef e Le bol rouge. Disponíveis em: http://www.fondationlecorbusier.fr. Acesso em 20 de fevereiro de 2017.

08 e 09 Pavilhão "L’Esprit Nouveau", Le Corbusier, Paris, 1925. Disponível em: http:// www.fondationlecorbusier.fr. Acesso em 20 de fevereiro de 2017.

10 Pavilhão "Cité dans L'Espace”, Frederick Kiesler, Paris, 1925. Disponível em: https://www.kiesler.org/en/. Acesso em 20 de fevereiro de 2017.

11 e 12 Villa Savoye, Le Corbusier, Paris, 1929. Disponível em: http://www. fondationlecorbusier.fr. Acesso em 20 de fevereiro de 2017.

13 El pueblo mexicano, José Clemente Orozco, 1930. Fotografia da autora na Casa Estúdio Barragán, 2017. Arquivo pessoal.

14 a 16 Ático Carlos Beistegui, Le Corbuiser, Paris, 1930. Disponível em: http://www. fondationlecorbusier.fr. Acesso em 20 de fevereiro de 2017.

17 Space house, Frederick Kiesler, Nova lorque 1933. Disponível em: Revista Architectural Record, janeiro 1934.

18 e 19 Film Guild Cinema, Nova Iorque, Frederick Kiesler, 1929. Disponível em: ZANCO, Federica. Luis Barragán, La revolución callada. Itália: Skira, 2002.

20 Valle de México desde el Río Morales, José María Velasco, 1891. Fotografia da autora no MUNAL (Museo Nacional de Arte Nacional), Cidade do México, 2017. Arquivo pessoal.

21 a 23 Paisagem entre Jalisco e Cidade do México, fotografias da autora, 2017. Arquivo pessoal. 
pessoal.

25 Cuauhtémoc em expansão, anos 1930, autor desconhecido. Disponível em:

ZANCO, Federica. Luis Barragán, La revolución callada. Itália: Skira, 2002.

26 a 30 Edifícios Rua Río Elba, Luis Barragán, Cidade do México, 1940. Fotografias da autora, 2017. Arquivo pessoal.

31 e 32 Duas Casas Av. México, Luis Barragán, Cidade do México, 1936. Fotografias da autora, 2017. Arquivo pessoal.

33 a 35 Casa Estúdio Orozco, Luis Barragán, Cidade do México, 1940. Fotografias da autora, 2017. Arquivo pessoal.

36 Casa Rua Rio Guadiana, Luis Barragán, Cidade do México, 1936. Fotografia da autora, 2017. Arquivo pessoal.

37 Edifício Av. Mississippi, Luis Barragán, Cidade do México, 1938-1940. Fotografias da autora, 2017. Arquivo pessoal.

38 e 39 Conjunto de edifícios Plaza Melchor Ocampo, Cidade do México, 1939-1941. Fotografias da autora, 2017. Arquivo pessoal.

38 Casa Av. Mazatlán, Luis Barragán, Cidade do México, 1936. Fotografias da autora, 2017. Arquivo pessoal

41 a 45 Conjunto de edifício e casas Rua Sullivan, Luis Barragán, Cidade do México, 1939. Fotografias da autora, 2017. Arquivo pessoal.

46 Implantação Casa Estúdio para 4 Pintores. Ilustração elaborada pela autora.

Arquivo pessoal.

47 Casa Estúdio para 4 Pintores, Luis Barragán e Max Cetto, Cidade do México, 1939-1941. Fotografias da autora, 2017. Arquivo pessoal.

48 a 49 Casa Estúdio para 4 Pintores, Luis Barragán e Max Cetto, Cidade do México, 1939-1941. Fotografias Rafael Gamo, 2017. Gentilmente concedidas pelo escritório de arquitetura mexicano Vrtical (Luis Beltrán e Andrew Sosa).

\section{Terceira fase (a partir de 1945)}

01 Mensagem em folha de ouro, Mathias Goeritz, 1967-1968. Hotel Camino Real, Cidade do México. Fotografia da autora, 2017. Arquivo pessoal.

02 Naturaleza muerta con sandía, Jesús "Chucho" Reyes, s/ data. Disponível em: KASSNER, Lily. Chucho Reyes. México: Editorial RM, 2002.

03 a 05 Espacio Escultórico, UNAM, 1977. Fotografias da autora, 2017. Arquivo pessoal.

06 e 07 Reserva Ecológica El Pedregal de San Ángel, UNAM. Fotografias da autora, 2017. Arquivo pessoal.

08 El Cabrío. Disponível em: RIGGEN, Antonio Martinez. Luis Barragán: escritos y conversaciones. Madri: Ed. El Croquis, 2000.

09 El Pedregal, Dr. Atl , 1946. Disponível em: EGGENER, Keith. Luis Barragán's gardens of El Pedregal. Nova lorque: Princeton Architectural Press, 2001.

10 Plano geral Jardines de El Pedregal. Ilustração da autora sobre imagem.

Disponível em: EGGENER, Keith. Luis Barragán's gardens of El Pedregal. Nova lorque: Princeton Architectural Press, 2001.

11 a 25 Jardines de El Pedregal San Ángel. Fotografias de Armando Salas Portugal. Disponível em: SALAS, Armando Portugal. Morada de Lava: Las Colecciones 
Fotograficas del Pedregal de San Ángel y La Ciudad Universitaria. México: UNAM, 2006. 26 Casa Estúdio Barragán, Luis Barragán, Cidade do México, 1947-1948. Fotografias da autora, 2017. Arquivo pessoal.

27 Casa Ortega, Luis Barragán, Cidade do México, 1941-1943. Fotografias da autora, 2017. Arquivo pessoal.

28 a 30 Construções em Tacubaya. Fotografias da autora, 2017. Arquivo pessoal. 32 a 65 Casa Estúdio Barragán, Luis Barragán, Cidade do México, 1947-1948. Fotografias da autora, 2017. Arquivo pessoal.

66 Implantação Construções em Tacubaya. Ilustração elaborada pela autora. Arquivo pessoal.

67 a 90 Casa Ortega, Luis Barragán, Cidade do México, 1941-1943. Fotografias da autora, 2017. Arquivo pessoal.

92 a 94 Anexo ateliê, Luis Barragán, Cidade do México, sem data. Fotografias da autora, 2017. Arquivo pessoal.

95 a 97 Postais de viagem Luis Barragán, sem data. Arquivo Fundação Barragán, Cidade do México.

98 Capela e ampliação Convento de Tlalpan, Luis Barragán, Cidade do México, 19531960 e 1979-1980. Fotografia da autora, 2016. Arquivo pessoal.

99 Implantação Capela e ampliação Convento de Tlalpan. Ilustração elaborada pela autora. Arquivo pessoal.

\section{Considerações finais}

01 Edifício Rua Río Mississippi, esquina Melchor Ocampo. Fotografia da autora, 2017. Arquivo pessoal.

02 Las arboledas, Luis Barragán, Cidade do México, 1958-1963. Fotografia Armando Salas Portugal, 2017. Disponível em: SALAS, Armando Portugal. Fotografías de la arquitectura de Luis Barragán. Barcelona: Gustavo Gili, 1992.

03, 05, 20, 31 e 32 Casa Ortega, Luis Barragán, Cidade do México, 1941-1943. Fotografia da autora, 2017. Arquivo pessoal.

04 e 29 Quadra San Cristóbal, Luis Barragán, Cidade do México, 1966-1968.

Fotografia da autora, 2016. Arquivo pessoal.

05 e 12, 19 e 34 Casa Pietro López, Luis Barragán, Cidade do México, 1948-1951.

Fotografia da autora, 2016. Arquivo pessoal.

06, 08, 11, 14, 16, 18, 26 e 33 Casa Estúdio Barragán, Luis Barragán, Cidade do México, 1947-1948. Fotografias da autora, 2017. Arquivo pessoal.

09 Edifício Rua Río Elba, Luis Barragán, Cidade do México, 1940. Fotografia da autora, 2017. Arquivo pessoal.

10 Casa Cristo, Luis Barragán, Gualajara, 1929. Fotografia da autora, 2017. Arquivo pessoal.

13 Casa Gilardi, Luis Barragán, Cidade do México, 1975-1977. Fotografia Onnis Luque, 2010. Gentilmente concedida para a pesquisa.

15 e 35 Casa Gálvez, Luis Barragán, Cidade do México, 1955. Fotografias da autora, 2017. Arquivo pessoal.

17 e 23 Casa Gilardi, Luis Barragán, Cidade do México, 1975-1977. Fotografia da autora, 2016. Arquivo pessoal.

22 e 30 Capela e Ampliação Convento de Tlalpan, Luis Barragán, 1953-1960 e 
1979-1980. Fotografia de Armando Salas Portugal, sem data. Disponível em:

SALAS, Armando Portugal. Fotografías de la arquitectura de Luis Barragán. Barcelona:

Gustavo Gili, 1992.

24 Casa Barragán, Luis Barragán, Chapala, 1932. Fotografia da autora, 2016.

Arquivo pessoal.

25 Jardines de El Pedregal San Ángel. Fotografia de Armando Salas Portugal.

Disponível em: SALAS, Armando Portugal. Morada de Lava: Las Colecciones

Fotograficas del Pedregal de San Ángel y La Ciudad Universitaria. México: UNAM, 2006.

27 Casa González Luna, Luis Barragán, Gualajara, 1928-1929. Fotografia da autora,

2017. Arquivo pessoal.

28 Casas Franco, Luis Barragán, Gudalajara, 1929. Fotografias da autora, 2017.

Arquivo pessoal.

34 Los Clubes, Luis Barragán, Cidade do México, 1961-1972. Fotografia da autora,

2016. Arquivo pessoal. 


\section{Referências bibliográficas}

\section{Livros}

ADRIÀ, Miquel. La sombra del Cuervo. Arquitectos mexicanos tras la senda de Le Corbusier. México: Arquine, 2016.

; e CASTILLO, José. El verdadeiro lujo está en el espacio. Últimas entrevistas con Ricardo Legorreta. México: Arquine, 2012.

AGAMBEN, Giorgio. O que é o contemporâneo? E outros ensaios. Tradução Vinicius Nicastro Honesko. Chapecó: Editora Argos, 2009.

AMBASZ, Emilio. The Architecture of Luis Barragán. New York: The Museum of Modern Art, 1976.

ANDA, Enrique Alanis X. de. Historia de la arquitectura mexicana. Barcelona: Gustavo Gili, 1995, 2006, 2013.

ANDA, Enrique Alanis X. de (org.). Luis Barragán: Clásico del silencio. Bogotá: Escala, 1989.

; Luis Barragán 1990 Historia de un debate. México: UNAM, 2016.

ALFARO, Alfonso. Voces de tinta dormida: Itinerarios espirituales de Luis Barragán. México: Editorial RM, 1996.

ANTEQUERA, Marino. La Alhambra y el Generalife. Granada: Editorial "Padre Suarez", 1961.

ARSANIOS, Marwa; DEBALL, Mariana Castillo, BLAKE, Jorge Méndez;

MONASTERIO, Rodrigo Ortiz; PODESVA, Kristina Lee; RONICKE, Pia e ROZENTAL,

Sandra. Tradición versus Modernidad. México: Archivo Diseño y Arquitectura, 2014.

BAC, Ferdinand. Jardins Enchantés. Paris: Louis Conard, 1925.

BACHELARD, Gaston. $O$ ar e os sonhos: ensaio sobre a imaginação do movimento. São Paulo: Martins Fontes, 2009.

BARBARIN, Antonio Ruiz. Luis Barragán frente al espejo. La otra mirada. Barcelona: Fundación Caja de Arquitectos, colección Arquia/tesis n.26, 2008.

BARRAGÁN, Luis; e FERREIRA, Raúl. Ensayos y apuntes para un bosquejo crítico. México: Museo Rufino Tamayo, 1985.

; Luis Barragán Capilla en Tlalpan. México: Sirio Editores, 1980.

BARRAGÁN, Luis. Discurso de aceptación del Premio, p. 58-61, 1980. In: RIGGEN, Antonio Martinez. Luis Barragán: escritos y conversaciones. Madri: Ed. El Croquis, 2000. 
; Los colores de México. Entrevista. Jorge Salvat, p. 128-131, 1981. In: RIGGEN, Antonio Martinez. Luis Barragán: escritos y conversaciones. Madri: Ed. El Croquis, 2000.

; La arquitectura de Luis Barragán. Extracto de las conversaciones, p. 103-104, 1976. In: RIGGEN, Antonio Martinez. Luis Barragán: escritos y conversaciones. Madri: Ed. El Croquis, 2000.

; Gardens for enviroment. Jardines de El Pedregal. Conferência dada em 6 de Outubro no Conselho de Arquitetos em Coronado, Califórnia, p. 36-40, 1951. In: RIGGEN, Antonio Martinez. Luis Barragán: escritos y conversaciones. Madri: Ed. El Croquis, 2000.

; Los jardines de Luis Barragán. Entrevista. Alejandro Ramírez Ugarte, p. 72-89, 1962. In: RIGGEN, Antonio Martinez. Luis Barragán: escritos y conversaciones. Madri: Ed. El Croquis, 2000.

; Luis Barragán a familia. Carta enviada desde Paris a Guadalajara, p. 139, 1924.

In: RIGGEN, Antonio Martinez. Luis Barragán: escritos y conversaciones. Madri: Ed. El Croquis, 2000.

; Luis Barragán. Entrevista. Elena Poniatowska, p. 105-123, 1976. In: RIGGEN, Antonio Martinez. Luis Barragán: escritos y conversaciones. Madri: Ed. El Croquis, 2000.

; Apuntes de Nueva York. Ideas sobre Jardines, p. 15-16, 1931. In: RIGGEN, Antonio Martinez. Luis Barragán: escritos y conversaciones. Madri: Ed. El Croquis, 2000.

; Apuntes desde París. Ideas sobre arquitectura contemporánea, p. 17, 1931.

In: RIGGEN, Antonio Martinez. Luis Barragán: escritos y conversaciones. Madri: Ed. El Croquis, 2000.

; Precisiones sobre "El Cabrío", p. 30-31, 1945. In: RIGGEN, Antonio Martinez. Luis Barragán: escritos y conversaciones. Madri: Ed. El Croquis, 2000.

; Algunas ideas para el desarrollo de "El Parque Residencial de El Pedregal de San Ángel", p. 22-23, 1944. In: RIGGEN, Antonio Martinez. Luis Barragán: escritos y conversaciones. Madri: Ed. El Croquis, 2000.

BAXANDALL, Michael. Padrões de intenção. A explicação histórica dos quadros. São Paulo: Companhia das Letras, 2006.

BAYÓN, Damían; GASPARINI, Paolo. Panoramica de la arquitectura latinoamericana. Barcelona: Editorial Blume, 1977.

BELTRÁN, Antonio. Altamira. Barcelona: Lunwerg Editores, 1998.

BENEVOLO, Leonardo. História da arquitetura moderna. São Paulo: Perspectiva, $1^{\text {a }}$ edição, 1976.

BERGH, Wim van den; ZWARTS, Kim. The Eye Embodied. Maastricht: Pale Pink Publishers, 2006.

BERGDOLL, Barry. Latin America in Construction: Architecture 1955-1980. New York: MOMA-NY, 2015.

BERGSON, Henri. O Pensamento e o Movente. São Paulo: Martins Fontes, 2006.

BOESIGER, Willy. Le Corbusier. São Paulo: Martins Fontes, 1994. ; e GIRSBERG. Le Corbusier 1910-65. Barcelona: Editorial Gustavo Gili, $5^{\text {a }}$ edição, 1995. 
BORGES, Jorge Luis. Fiç̧ões. São Paulo: Editora Schwarcz, 2008. (1ª edição 1944). ; Historia de la noche. Buenos Aires: Emecé, 1977.

BRILLEMBOURG, Carlos (ed.). Latin American Architecture 1929-1960. Contemporary Reflections. Nova lorque: The Monacelli Press, 2004.

BROWNE, Enrique. Otra arquitectura en América Latina. Barcelona: Gustavo Gili, 1988. BUENDÍA, José María; EGUIARTE, Guillermo; e PALOMAR, Juan. Luis Barragán. México: Editorial RM, 2013.

BUENDÍA, José María. The life and work of Luis Barragán. New York: Rizzoli, 1997. ; De arquitectura (construcciones desde el imaginario). México: Editorial RM,

2007.

BULLRICH, Francisco. Nuevos caminos de la arquitectura Latinoamericana. Barcelona: Ed. Blume, 1969.

BURIAN, Edward (ed.). Modernidad y arquitectura en México. Barcelona: Gustavo Gili, 1998.

BURRI, René. Luis Barragán. Londres: Phaidon, 2000.

CAMPOS, Beatriz de Maira; e CORCUERA, Catalina. Luis Barragán, arquitecto de la luz y el silencio. México: Tecolote, 2015.

CAMPOS BAEZA, Alberto. La idea construída. Madrid: Nobuko, 2008.

CANALES, Fernanda; e GÁLVEZ, Alejandro Hernández. 100x100 arquitectos del sigo XX en México. Cidade do México: Arquine, 2011.

CASTILLO, Christian del; e MIRANDA, David. Guía Goeritz. México: Arquine. 2015. CASTREJÓN, Aníbal Figueroa. El período funcionalista de Luis Barragán: los años heroicos, p. 73, 1989. In: ANDA, Enrique Alanis X. de. Luis Barragán 1990 Historia de un debate. México: UNAM, 2016.

CURTIS, William. Arquitetura moderna desde 1900. Porto Alegre: Artmed Editora S.A, $3^{\mathrm{a}}$ edição, 2008. (1ª edição 1982).

GARAY, Graciela. Mario Pani vida e obra. México: UNAM, 2004.

EDER, Rita. Muralismo mexicano: modernidade e indentidad cultural. In: BELLUZO, Ana Maria de M. (org.). Modernidade: vanguardas artísticas na América Latina. São Paulo: Memorial: Unesp, 1990.

EGGENER, Keith. Luis Barragán's gardens of El Pedregal. Nova lorque: Princeton Architectural Press, 2001.

FERRAZ, Marcelo; VAINER, André (org.). Cidadela da Liberdade: Lina Bo Bardi e o Sesc Pompeia. São Paulo: Ed. SESC SP, 2013.

FRAMPTON, Kenneth. História Crítica da Arquitetura Moderna. São Paulo: Martins Fontes, 2008.

FRASER, Valerie. Building the New World. Studies in the Modern Architecture of Latin America 1930-1960. Londres: Verso, 2000.

GARCÍA, Laura. Mathias Goeritz ecos y labirintos. México: Artes de México, 2014. GÓMEZ, Mauricio Mayorga. Ensayos críticos de arquitectura. Guadalajara: Talleres gráficos UAG, 1977.

GORCHES, Gabriela; e CORCUERA, Susana. Entre el arte y la ciencia, José María Velasco. México: Tecolote, 2013.

GORELIK, Adrián. Das vanguardas à Brasília - Cultura Urbana e Arquitetura na América Latina. Tradução de Maria Antonieta Pereira. Belo Horizonte: Editora UFMG, 2005.

GORTÁZAR, Fernando González. Las torres de Ciudad Satélite. México: Arquine, 2014. 
HITCHCOCK, Henry-Russel. Latin American Architecture since 1945. MoMA-New York, 1955.

KASSNER, Lily. Chucho Reyes. México: Editorial RM, 2002.

LE CORBUSIER. Por uma arquitetura. São Paulo: Perspectiva, 2002.

; Precisões sobre um estado presente da arquitetura e do urbanismo. São

Paulo: Cosac Naify, 2004.

LEFAIVRE, Liane e TZONIS, Alexander. Critical Regionalism. Architecture and Identity in a Globolized World. Alemanha: Prestel, 2003.

LEJEUNE, Jean-François (ed.). Cruelty \& Utopia: Cities and Landscapes of Latin America. Nova lorque: Princeton Architectural Press, 2006.

LIERNUR, Jorge Francisco. Un nuevo mundo para el espíritu nuevo: los descubimientos de América Latina por la cultura arquitectónica del siglo XX. In: Trazas de futuro:

Episodios de la cultura arquitectónica de la modernidade en América Latina. Santa Fe: Universidad Nacional del Litoral, 2008.

LOBO, Carlos González. Guía O'Gorman. México: Arquine + Editorial RM. 2008.

MARTÍNEZ, José Luis; e OROPEZA, Guillermo Garcia. Guadalajara La perla del Occidente de México. México: Fomento Cultural Banamex, 1990.

MAIAKOVSKI, Vladimir. Mi descubrimiento de América. $1^{\text {a }}$ ed. - Buenos Aires:

Entropía, 2015.

MALRAUX, André. O Museu Imaginário. Lisboa: Edições 70, 2000.

MONEO, Rafael. Inquietação teórica e estratégia projetual. São Paulo: Cosac \& Naify, 2008.

MONTANER, Josep Maria. Arquitetura e crítica. Barcelona: Gustavo Gili, 2007.

MONTEYS, Xavier. La arquitectura de Luis Barragán: uma arquitectura de recintos, $\mathrm{p}$.

108, 1989. In: ANDA, Enrique Alanis X. de. Luis Barragán 1990 Historia de un debate.

México: UNAM, 2016.

NESBITT, Keith (org.). Uma nova agenda para a arquitetura: uma antologia teórica (1965-1995). São Paulo: Cosac \& Naify, 2006.

NOELLE, Louise. Luis Barragán. Búsqueda y creatividad. México: UNAM, 2004. (1ª edição 1996).

NORBERG-SCHULZ, Christian. Existencia, Espacio y Arquitectura. Barcelona: Editorial Blume, 1975. ; Intenciones en Arquitectura. 2a edição. Barcelona: Editorial Gustavo Gili, 1998.

; Genius loci. Towards a phenomenology of architecture. Nova lorque: Rizzoli. $2^{a}$ edição, 1980. (Primeira edição Milão: Grupo Editoriale Electa, 1979).

; O fenômeno do lugar, p. 459, 1976. In: NESBITT, Keith (org.). Uma nova agenda para a arquitetura: uma antologia teórica (1965-1995). São Paulo: Cosac \& Naify, 2006.

OBRIST, Hans Ulrich; REYES, Pedro. El aire es azul - reflexiones sobre el arte y arquitectura en torno a la obra de Luis Barragán. Cidade do México: ed. Lar e Trilce, 2006.

O'GORMAN, Edmundo. A invenção da América. Reflexão a respeito da estrutura histórica do novo mundo e do sentido do seu devir. São Paulo: Editora da UNESP, 1992. ORENDÁIN, María Elena. En busca de Luis Barragán. México: Universidad Autónoma Metropolitana, 2004. 
OZENFANT, Amedée; e JEANNERET, Charles Édouard. Depois do cubismo. São Paulo: Cosac Naify, 2005. Título original: Après le cubisme (1918).

PAZ, Octavio. El labirinto de la soledad. Madrid: Cátedra. 16º edición, 2010. ; O arco e a lira. São Paulo: Cosac Naify, 2014, $2^{\text {a }}$ edição.

PAULY, Danièle. Barragán. L'espace et L'ombre, le mur et la couleur. Basel - Boston Berlim: Birkhauser, 2002.

PEREIRA, Armando. Diccionário de literatura mexicana siglo XX. México: UNAM, 2000.

RICALDE, Humberto. Entre la morada y el pensamiento... (Una reflexión sobre Luis Barragán), p. 121-122, 1989. In: ANDA, Enrique Alanis X. de. Luis Barragán 1990 Historia de un debate. México: UNAM, 2016.

RIGGEN, Antonio Martinez. Luis Barragán: escritos y conversaciones. Madri: Ed. El Croquis, 2000.

RISPA, Raul (ed.). Barragán: The Complete Works. New York: Princeton Architectural Press, 1996.

RIVERA, Diego. Requisitos para la organización de "El Pedregal", p. 24-26, 1935. In: RIGGEN, Antonio Martinez. Luis Barragán: escritos y conversaciones. Madri: Ed. El Croquis, 2000.

RULFO, Juan. Letras e imágenes. México: Editorial RM, 2002. ; El Llano en llamas. México: Anagrama, 1993. (1ª edição 1953).

SAITO, Yutaka. Luis Barragán. Mexico City: Noriega, 1994.

SALAS, Armando Portugal. Photographs of the Architecture of Luis Barragán. New York: Rizzoli, 1992. ; Fotografías de la arquitectura de Luis Barragán. Barcelona: Gustavo Gili, 1992.

; Morada de Lava: Las Colecciones Fotograficas del Pedregal de San Ángel y La Ciudad Universitaria. México: UNAM, 2006.

SANTOS, Milton. Técnica, espaço, tempo. São Paulo: Edusp, 2008.

SINGER, Paul. América del Sur 2006: de la geografia a la historia. In: GONZÁLEZ, Helena \&SCHMIDT, Heidulf. Democracia para una nueva sociedade (modelo para armar). Caracas: Nueva Sociedad, 1997.

SMITH, Clive Bamford. Builders in the sun. Five Mexican Architects. Nova Iorque: Architectural Book Publishing CO, 1967.

UGARTE, Alejandro Ramírez. Conversación con Luis Barragán. México: Arquitetónica + llajac. 2015.

URSPRUNG, Philip; LOPES, Diogo e BANDEIRA, Pedro. Eduardo Souto de Moura Atlas de Parede Imagens de Método. Porto: Dafne Editora, 2011.

VALÉRY, Paul. Introdução ao método de Leonardo da Vinci. São Paulo: Editora 34 1998.

ZANCO, Federica. Luis Barragán, La revolución callada. Itália: Skira, 2002. ; e VALENTE, Ilaria. Guía Barragán. Cidade do México: Fundação Barragán /

Arquine, 2011

\section{Artigos, dissertações e teses}

ARELLANO, Alfonso. América Latina, historiografia y arquitectura. Trienal de Investigación, Facultad de Arquitectura y Urbanismo Universidad Central Venezuela, 2011.

BENOIT, Alexandre. O labor secreto de Le Corbusier. Dissertação de mestrado. 
Área de concentração: História e Fundamentos de Arquitetura e Urbanismo da Faculdade de Arquitetura e Urbanismo da Universidade de São Paulo, 2014.

BORN, Esther. Children's Park. Parque de la Revolución. Designed by Luis Barragán architect, Juan Luis Barragán civil engineer. The Architectural Record, número 3, vol. 78, setembro de 1935. ; Park of the Revolution. Luis Barragán architect, Juan Luis Barragán civil engineer, Speculation House. Luis Barragán architect; Two-family house in Mexico City. Luis Barragán architect. The Architectural Record, número 4, vol. 81, abril de 1937. CANALES, Fernanda. La modernidad arquitectónica en México; una mirada a través del arte y de los médios impresos. Tese de doutorado. Madri. Departamento de Proyectos Arquitectónicos, Escuela Técnica Superior de Arquitectura de Madrid, 2013.

CETTO, Bettina. Luis Barragán y su maestría con los jardines. Revista Bitácora Arquitectura, número 31, 2015.

CETTO, Max. Edificaciones de un paisaje volcánico en México. Revista Bitácora Arquitectura, número 32, 2016. Edição fac-símile do artigo original de Max Cetto "Bauten in Einer LavalandSchaft Mexicos" publicado em Baukunst und Werkform 1-2 em 1954.

FERNÁNDEZ, Justino. Arquitectura contemporánea. Revista de la Universidad de México, número 27, abril, 1938.

; Le Corbusier, pintor y escultor. Revista de la Universidad de México, número 3, novembro, 1965.

FLORES, Oscar Salinas. Clara Porset. Revista Bitácora Arquitectura, número 7, 2002. GODOY, Iliana. Espacios de la ausencia: De Chirico, Villarrutia y Barragán. Revista Bitácora Arquitectura, número 2, 1997.

GORTÁZAR, Fernando González. La arquitectura contemporánea en Jalisco. Revista de la Universidad de México, número 1, setembro, 1975.

LE CORBUSIER. O espaço indizível. In: Arq.Urb, número 14, segundo semestre de 2015. São Paulo, USJT, 2015.

O.B. Seclusion and serenity. Domus 611, novembro 1980.

PALOMAR, Juan. El alquimista de la memoria, p. 22, 1994. In: Revista Artes de México, número 23. En el mundo de Luis Barragán.

PAZ, Octavio. Los usos de la tradicón, p. 17, 1994. In: Revista Artes de México, número 23. En el mundo de Luis Barragán.

PIGNATARI, Décio. Teotihuacan: o design da água. Revista Através, número 1, 1983.

PONTI, Gio. I muri di Luis Barragán. Domus 468, novembro 1968. ; Il Pedregal di Città del Messico. Domus 280, março 1953.

RICALDI, Humberto. Pensar, edificar, morar. Uma reflexión sobre Luis Barragán. Revista de la Universidad de México número 7, 2004.

RODRÍGUEZ, Ida. Surrealismo y arte fantástico en México. Revista de la Universidad de México, número 12, agosto, 1967.

ROZESTRATEN, Artur Simões. Ensaio para diálogos futuros sobre o espaço indizível. In: Arq.Urb, número 14, segundo semestre 2015. São Paulo.: USJT, 2015.

SALGUERO, Ramón, Vargas. Porfirismo: Afirmación del nacionalismo y la modernidad. Revista Bitácora Arquitectura, número 2, 2000.

SEM AUTOR, Mexican Villas. Luis Barragán Architect, The Architectural Record, número 3, vol. 70, setembro de 1931. 
SEM AUTOR, Modernist Houses in Mexico. Designed by Luis Barragán, House and Garden, outubro de 1931.

SEM AUTOR. Barragán a città del Messico. Domus 321, agosto 1956.

ZANCO, Federica. Barragán’s Ciudad de México. Domus 899, janeiro 2007. 


\section{Cronologia de obras Luis Barragán}

1926

Reforma Casa Robles León

Rua Madero, 607. Guadalajara

1927-1928

Casa Robles Castillo I e Casa Robles Castillo II Av. Vallarta 1095 e Rua Argentina, 27. Guadalajara

\section{8}

Casa Enrique Aguilar (demolida)

Rua Manuel López Cotilla, 1505. Guadalajara

Casas centro de Guadalajara (setor Hidalgo)

Rua Liceo, 331, Rua Pedro Loza, 517 e Rua Prosperidad, 74. Guadalajara

\section{8-1929}

Casa González Luna

Rua José Guadalupe Zuno, 2083. Guadalajara

\section{9}

Duas casas para aluguel Efraín González Luna

Rua Zaragoza, 265 e 267. Guadalajara

\section{Casa Cristo}

Rua Pedro Moreno, 1671. Guadalajara

Casas Franco

Av. de La Paz, 2207 e Rua Simón Bolívar, 224. Guadalajara

Duas casas para aluguel para Robles León

Av. de La Paz. Guadalajara

\section{0}

Cine Colón

Rua Colón, esquina Nueva Galicia. Guadalajara

Casa Dr. Medina

Av. de La Paz, 1877. Guadalajara

\section{1}

Casa Cristo, Chapala

Rua Zaragoza, 307. Chapala, Jalisco

\section{2}

Reforma Casa da família Barragán Chapala Av. Madero. Chapala, Jalisco 
Duas Igrejas e suas respectivas praças frontais

Povoado próximo à Corrales. Jalisco. Localização exata desconhecida.

\section{4-1935}

Casa Carmen Orozco (demolida)

Rua Manuel López Cotilla, 1034. Guadalajara

1934

Quiosque para a Praça de Chapala (demolido)

Chapala, Jalisco

Casa para aluguel

Rua Rayón, 121. Guadalajara

Casa para aluguel Robles León

Rua Marcos Castellanos, 132. Guadalajara

Casa Harper de Garibi

Rua Rayón, 123. Guadalajara

Casa para Efraín González Luna (parcialmente demolida)

Rua Marcos Castellanos, esquina Rua Manuel López Cotilla. Guadalajara

Casa José Clemente Orozco

Rua Manuel López Cotilla, 846. Guadalajara

Cine Jalisco (transformado radicalmente)

Localização desconhecida. Guadalajara

Parque Revolución em colaboração com Juan José Barragán

Av. Juárez, s/n, Centro. Guadalajara

1936

Casas para aluguel (modificada)

Av. Mississippi, 98 e 90, Cuauhtémoc. Cidade do México

Duas Casas Avenida México

Av. Parque México, 141 e 143, Hipódromo Condesa. Cidade do México

Casa para aluguel M. Pilar Uribe (modificada)

Av. Mazatlán, 116, Condesa. Cidade do México

Duas casas para aluguel Raúl Ortega Amezcua (modificadas)

Av. Mazatlán, 118, Condesa. Cidade do México

\section{6-1940}

Edifícios Río Elba

Río Elba, 38, 50, 52 e 56. Cuauhtémoc, Cidade do México (56 demolido)

Edifício José Mojica

Av. Parque Melchor Ocampo, 12. Cuauhtémoc, Cidade do México

Casa J. Chávez Peón de Ochoa

Av. Mississipi, 61. Cuauhtémoc, Cidade do México

Casa para aluguel

Rua Río Guadiana, 3. Cuauhtémoc, Cidade do México

Edifício Lorenzo Garza

Av. Parque Melchor Ocampo, 40. Cuauhtémoc, Cidade do México

Edifício Concepción Ribot (demolido)

Av. Río Mississipi, esquina Río Atoyac. Cuauhtémoc, Cidade do México

Edifício Carmen R. G. De Cristo

Av. Río Mississipi, 65. Cuauhtémoc, Cidade do México

Edifício M. de la Parra, Vda. De Verduzco

Río Elba, 70. Cuauhtémoc, Cidade do México

Edifício (demolido)

Río Lerma e Río Guadiana, Cuauhtémoc, Cidade do México

Edifício Alfonso Barragán

Av. Río Mississipi. Cuauhtémoc, Cidade do México

Casa para aluguel Abraham Goldefer (modificada)

Av. Mazatlán, 114, Hipódromo Condesa, Cidade do México 
Remodelação da Igreja de Amatitán em colaboração com Ignácio Díaz Morales Amatitán, Jalisco

\section{7}

Casa I. Pizarro Suárez

Lomas de Chapultepec, Cidade do México

Edifício de apartamentos

Estocolmo, 14. Juárez, Cidade do México

Casa para aluguel Sr. Corcuera, Vda. de Alcázar (modificada)

Mazatlán, 130. Hipódromo Condesa, Cidade do México

\section{8}

Casa Dr. David Kostovetsky (modificada)

Av. Nuevo León, 103. Hipódromo Condesa, Cidade do México

\section{9-1941}

Edifício para 4 pintores em colaboração com Max Cetto

Av. Parque Melchor Ocampo, 38. Cuauhtémoc, Cidade do México

\section{0-1941}

Remodelação da Igreja de El Arenal em colaboração com Ignacio Díaz Morales El Arenal, Jalisco

\section{0}

Remodelação da casa e jardins de Alfredo Vázquez e Luz Barragán em colaboração com Alfredo Vázquez Chapala, Jalisco

Edifício Sullivan - conjunto de Edifício e casas para Arturo Figueroa Uriza

Rua Sullivan, 55, 57, 61. San Rafael, Cidade do México

Casa Eduardo Villaseñor (demolida)

San Ángel, Cidade do México

Quatro jardins privativos

Francisco Ramírez e Av. Constituyentes. Tacubaya, Cidade do México

Casa Estúdio Orozco

Calle Ignacio Mariscal, 132. Tabacalera, Cidade do México

\section{1-1943}

\section{Casa Ortega}

Francisco Ramírez, 10. Tacubaya, Cidade do México

\section{4}

Três jardins privativos "El Cabrío" (demolidos)

Av. San Geronimo. San Ángel, Cidade do México

\section{$1945-1950$}

Loteamento Parque Residencial Jardines del Pedregal

San Ángel, Cidade do México

\section{7}

Reforma na Vila Adriana

Av. Hidalgo, Chapala

\section{7-1948}

Casa Estúdio Luis Barragán

Francisco Ramírez, 14. Tacubaya, Cidade do México

Anexo ateliê - sem data

Francisco Ramírez, 17. Tacubaya, Cidade do México

\section{8}

Casa Pietro López

Av. de las Fuentes, 180. Pedregal de San Ángel, Cidade do México 
Duas casas El Pedregal em colaboração com Max Cetto

Av. de las Fuentes, 10 y 12. Pedregal de San Angel, Cidade do México

1949

Casa El Pedregal (demolida)

Rua Agua, 115. Pedregal de San Ángel, Cidade do México

1950

Casa em colaboração com Max Cetto

Av. de las Fuentes, 140. Pedregal de San Ángel, Cidade do México

Casa em colaboração com Max Cetto

Av. de las Fuentes, 130. Pedregal de San Ángel, Cidade do México

1952

Casa José Arriola Adame (demolida)

Av. de las Rosas, 543. Guadalajara

\section{3}

Áreas ajardinadas UNAM em colaboração com Max Cetto

Cidade Universitária, UNAM. Cidade do México

Estudos para fontes e centro comercial

Plaza Zócalo, Cidade do México

\section{3-1960 e 1979-1980}

Capela de las Madres Capuchinas e Ampliação Convento de Tlalpan

em colaboração com Jesús "Chucho" Reyes e Mathias Goeritz

Rua Miguel Hidalgo, 43. Tlalpan, Cidade do México

\section{4}

Remodelação da Casa de Alfredo Vázquez e Luz Barragán de Vázquez

em colaboração com Alfredo Vázquez

Rua Robles Gil, esquina rua Madero. Guadalajara

\section{Projeto Parque Azteca}

Cidade do México

\section{5}

Jardins e áreas externas do Hotel Pierre Marquez

Acapulco, Guerrero

Casa Gálvez

Rua Pimentel, 10. San Ángel, Cidade do México

Loteamento Jardines del Bosque

Guadalajara, Jalisco

Capela del Calvario

Loteamento Jardines del Bosque, Guadalajara. Jalisco

\section{5-1957}

Casa

Playa Majahua, Estado de Colima

\section{7-1958}

Torres Satélite em colaboração com Mathias Goeritz Periférico Norte e autopista Querétaro, Estado de México

\section{8-1961}

Loteamento Las Arboledas

Avenida Arboledas de la Hacienda, autopista México-Querétaro, Atizapán de Zaragoza, Estado de México

Muro Rojo

Loteamento Las Arboledas 
Praça e fonte do Campanário

Loteamento Las Arboledas

Praça e fonte bebedouro

Loteamento Las Arboledas

\section{2}

Projeto casa-tipo para Vila Olímpica em colaboração com Andrés Casillas

Cidade do México

\section{3-1964}

Loteamento Los Clubes

Acesso pela rua Verdín, San Mateo Tecoloapan, Atizapán de Zaragoza, Tlalnepantla, Estado de México

Fonte dos Amantes

Loteamento Los Clubes

\section{4}

Consultoria áreas externas Salk Institute - projeto de Louis Kahn

La Jolla, Califórnia

\section{4-1967}

Estudos para Capela Aberta

Lomas Verdes, Estado de México

Projeto urbanístico Lomas Verdes em colaboração com Juan Sordo Madaleno

Lomas Verdes, Estado de México

\section{8}

Acesso Los Clubes

Acesso pela rua Verdín, San Mateo Tecoloapan, Atizapán de Zaragoza, Tlalnepantla, Estado de México

\section{7-1968}

Quadra San Cristóbal e Casa Folke Egerstrom em colaboração com Andrés Casillas Rua Manantial Oriente, 20. Loteamento Los Clubes

\section{9}

Plano urbano Cano

Tepoztlán, Estado de México

\section{1}

Projeto preliminar para clube e pista de corrida de cavalos Guadalajara

Plaza Oval

Jardines de Morelos, Cuernavaca

\section{2}

Projeto Fonte Monumental Lomas Verdes em colaboração com Ricardo Legorretta Lomas Verdes, Estado de México

\section{Projeto Capela para o Loteamento El Palomar}

Guadalajara

\section{3}

Projeto Palomar - desenho preliminar para uma Torre Símbolo em colaboração com Raúl Ferreira Loteamento El Palomar, Guadalajara

Projeto para o acesso Loteamento El Palomar Guadalajara

\section{6}

Casa Gilardi

General León, 82.San Miguel de Chapultepec, Cidade do México 


\section{7}

Faro del Comércio

Macroplaza, Monterrey. Nuevo León

\section{1}

Casa Meyer em colaboração com Alberto Chauvet Bosques de las Lomas, Cidade do México

\section{1-1983}

Casa Váldes em colaboração com Raúl Ferreira Av. Alfonso Reyes, 298. Monterrey, Nuevo León 
Barragán em três tempos

Marina Panzoldo Canhadas

$\sum_{2}^{5 \times 4 a t}$ 